UNIVERSIDADE DE SÃO PAULO

FACULDADE DE FILOSOFIA, LETRAS E CIÊNCIAS HUMANAS

DEPARTAMENTO DE SOCIOLOGIA

PROGRAMA DE PÓS-GRADUAÇÃO EM SOCIOLOGIA

\title{
RAFAEL GODOI
}

Ao redor e através da prisão: cartografias do dispositivo carcerário contemporâneo

São Paulo

2010 


\author{
UNIVERSIDADE DE SÃO PAULO \\ FACULDADE DE FILOSOFIA, LETRAS E CIÊNCIAS HUMANAS \\ DEPARTAMENTO DE SOCIOLOGIA \\ PROGRAMA DE PÓS-GRADUAÇÃO EM SOCIOLOGIA
}

\title{
Ao redor e através da prisão: cartografias do dispositivo carcerário contemporâneo
}

\author{
Rafael Godoi
}

Dissertação apresentada ao Programa de Pós-Graduação de Sociologia da Faculdade de Filosofia, Letras e Ciências Humanas da Universidade de São Paulo, para a obtenção do título de Mestre em Sociologia.

Orientadora: Profa. Dra. Vera da Silva Telles.

São Paulo 
A pai e mãe, pelo passado; a Erika, pelo presente. 


\section{Agradecimentos}

A Vera Telles, pelo apoio, orientação e paciência. A Fernando Salla e Marcos Alvarez pelo diálogo continuado e pelas sugestões no exame de qualificação. A Eliane Alves, Daniel Hirata, José César Magalhães, Carlos Freire, Tatiana Maranhão, Fernanda Matsuda, Alessandra Teixeira pelos estudos compartilhados. Por ajudas várias nas atividades curriculares do programa de pós-graduação: Sérgio Adorno, Sylvia Garcia, Maria Helena Oliva Augusto, Myriam Mitjavila, Ângela de Souza, Vicente Filho. Por ajudas várias em situações várias: Rodrigo Godoi, Robert Cabanes, Gabriel Feltran, Álvaro Gullo, Alvino Sá, Fabio Candotti, Douglas Anfra, Ana Gabriela Braga, Gislene Souza, Bianca Briguglio. Da expedição à Barcelona: à Agência de Cooperação Internacional do Ministério de Assuntos Exteriores da Espanha, a Teresa Berteli, Montserrat Ventura, Verena Stolcke, Alex Coello, Aurora González, Julio Zino, Gloria

Urtasun. À Oficina Social de Antropologia e Prisão, a Dario Malventi e Álvaro Garreaud. A todos os interlocutores da pesquisa e a todos aqueles que na vida privada fizeram comigo essa travessia. 


\title{
Resumo
}

Nesse trabalho, a incidência da prisão para além de seus limites físicos e institucionais é problematizada a partir da exploração e confrontação de dois contextos sociais distintos: a Catalunha e São Paulo. Os vasos comunicantes que conectam a prisão a outros territórios sociais, bem como as experiências de diversos agentes que fazem a mediação entre o mundo prisional e a sociedade mais ampla, são questões abordadas através de uma perspectiva analítico-descritiva, visando evidenciar a produção de um multifacetado campo social estruturado ao redor e através das instituições prisionais. Explorando diferentes trajetórias que se conformam nesse campo é possível problematizar algumas das circunstâncias do processo de massificação do encarceramento, assim como outras importantes alterações recentes no dispositivo carcerário contemporâneo.

Palavras-chave: prisão, dispositivo carcerário, encarceramento em massa, vasos comunicantes, mediadores, sistema penitenciário, Catalunha, São Paulo.

\begin{abstract}
This work intends to problematize the impacts of prison beyond its physical and institutional limits. Such aim is achieved through exploration and confrontation of two different social contexts: Catalonia and São Paulo. The communicating vessels, which connect jail to other social territories, and the experience of several agents, that provide mediation between prison and the rest of society, are questions treated through an analytical-descriptive perspective, intending to show up the production of a multifaceted social field that is structured around and through prison institutions. Exploring different paths in this field, it is possible to problematize some circumstances of mass imprisonment process, as well as recent changes in the penal contemporary mechanism.
\end{abstract}

Key-words: prison, penal mechanism, mass imprisonment, communicating vessels, mediators, penitentiary system, Catalonia, São Paulo. 


\section{Sumário}

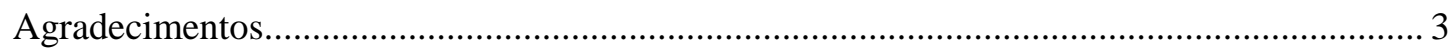

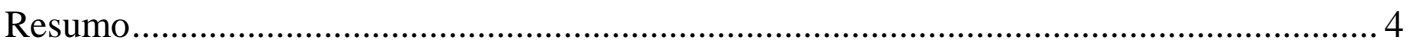

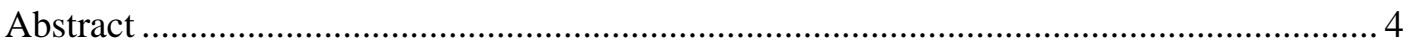

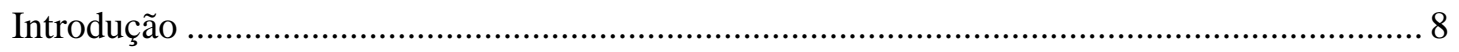

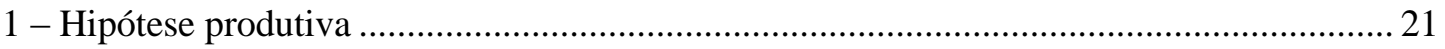

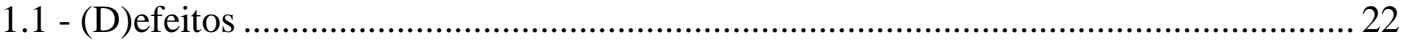

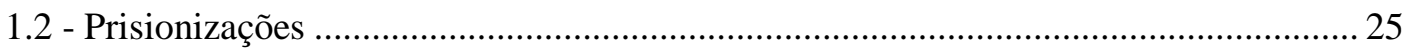

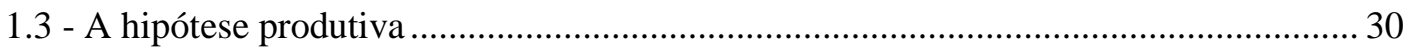

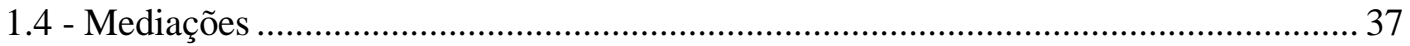

2 - Massificação do encarceramento ..................................................................................... 43

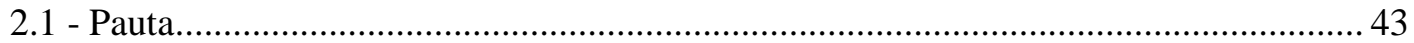

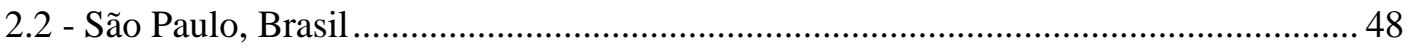

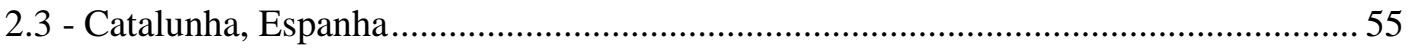

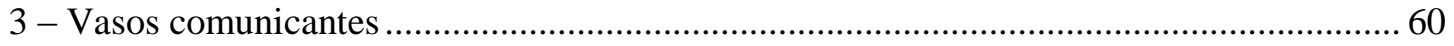

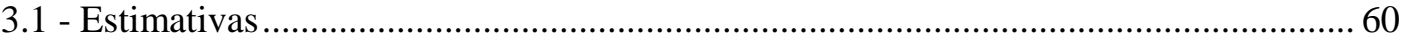

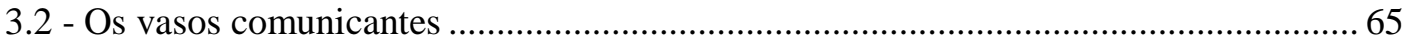

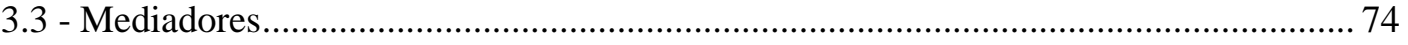

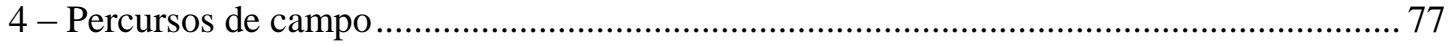

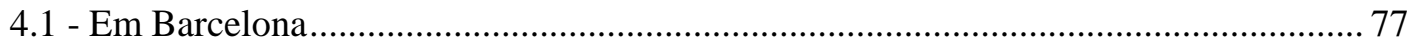

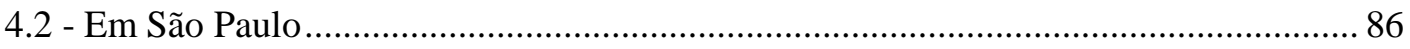

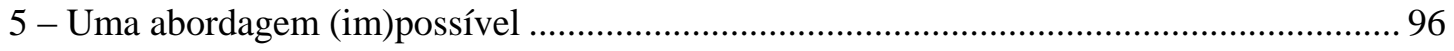

6 - Uma cartografia do dispositivo carcerário catalão ........................................................... 101

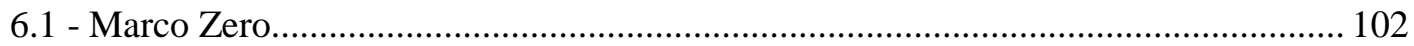

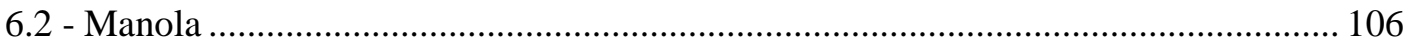

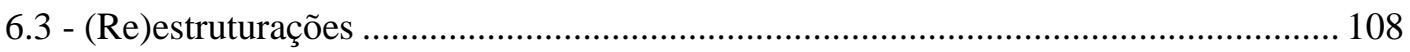

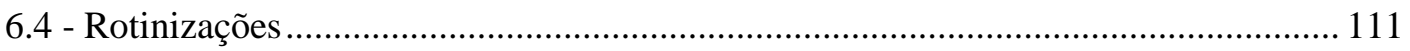

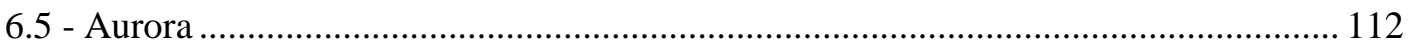

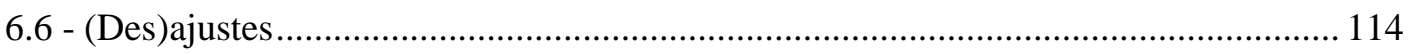

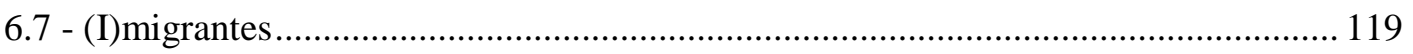

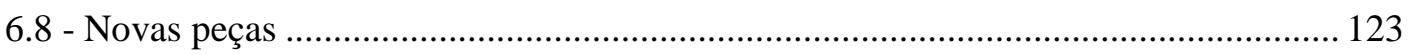

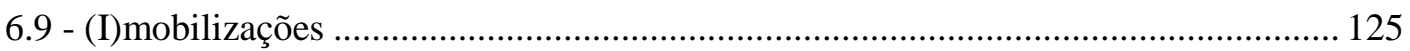

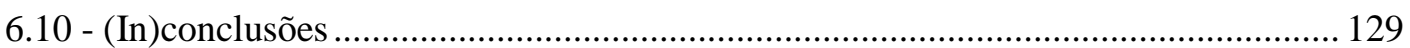


7 - Uma cartografia do dispositivo carcerário paulista ........................................................ 130

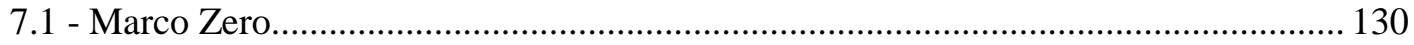

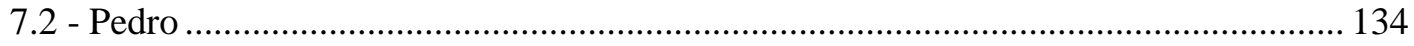

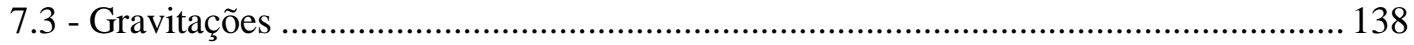

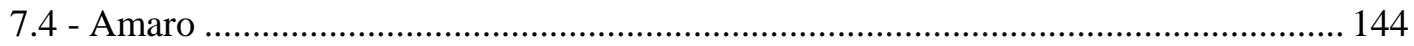

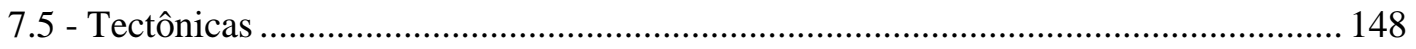

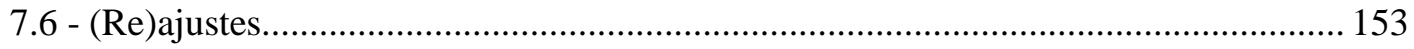

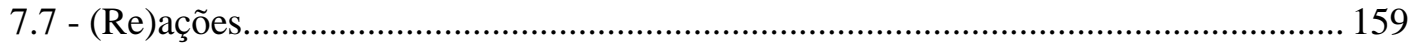

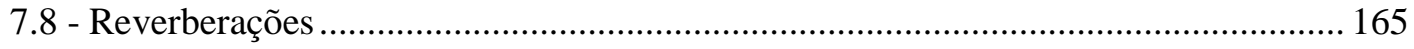

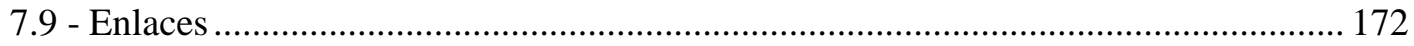

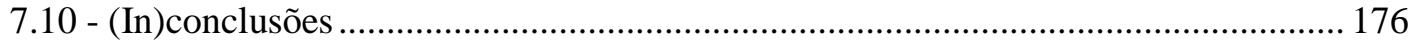

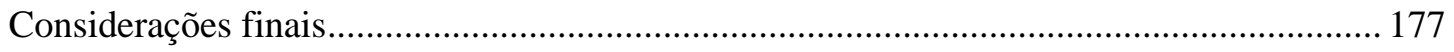

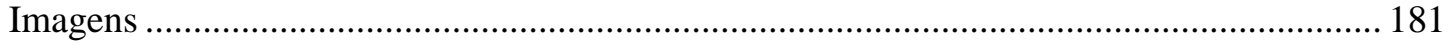

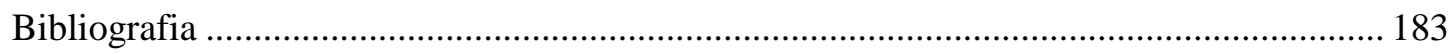

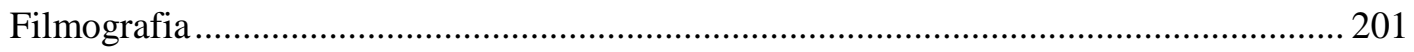


"Digo: o real não está na saída nem na chegada: ele se dispõe para a gente é no meio da travessia." Guimarães Rosa, em “Grande Sertão: Veredas.” 


\section{Introdução}

A presente pesquisa deve ser encarada como um percurso parcial, prático e teórico. Um trecho, um caminho possível, partindo de um ponto específico sem chegar num lugar pré-determinado. Um trecho, portanto, feito de desvios, de enganos, intuições, bifurcações, obstáculos, contornos e atalhos. O que segue deve ser lido como o relato de um percurso inacabado, um diário de viagem que está longe de encerrar-se. O ponto de partida pode ser precisado, os instrumentos de orientação utilizados podem ser enumerados, descritos, analisados. Já o ponto de chegada não passa de um entreposto provisório, ponto de parada e reflexão sobre o trecho percorrido e ainda a percorrer, um novo ponto de partida.

O início dessa jornada se dá no cruzamento de duas pistas - de dois conjuntos de evidências empíricas - que motivaram, conduziram e determinaram os (des)caminhos de toda a empreitada. Em primeiro lugar, a primeira pista: em diferentes bairros periféricos da cidade de São Paulo, um grupo de pesquisadores com os quais aprendia e colaborava encontrou a prisão. Mas não somente aquela prisão-possibilidade onipresente para os que se atreverem a cruzar os limites da legalidade instituída, e sim uma prisão-realidade, uma prisão-presença, e para pessoas que não necessariamente cometem ou cometeram um delito tipificado. Uma prisão que circula de boca em boca, de gesto em gesto, que sim ameaça em sua virtualidade, mas que, sobretudo, determina, coage, conforma efetivamente práticas e discursos de um grande número de habitantes daquelas localidades, estejam envolvidos ou não em negócios ilícitos.

Encontrou-se, é verdade, uma prisão-passado, a do relato de egressos do sistema prisional, de pessoas marcadas, estigmatizadas, "excluídas da sociedade", e que ali circulam normalmente, misturam-se desapercebidamente nos encontros fortuitos de bairro, que estão absolutamente incluídas em famílias extensas e nucleares, em sociabilidades de lazer e de mercado, desde o time de futebol, passando pelo bar e mercearia, até o ponto de tráfico de drogas. 
Encontrou-se ainda uma prisão-presente, aquela vivida pela mãe, pela sogra, pela mulher, pelos filhos de um encarcerado. Prisão-presente que se materializa nos fins de semana, nos dias de visita, no trajeto ao presídio distante, na longa fila de longa espera, na revista vexatória, na visita íntima; mas também uma prisão-presente a todo instante, nas necessidades básicas mais dificilmente supridas, no planejamento da viagem de visita, na produção do pacote de roupas, artigos de higiene e alimentos a levar ao encarcerado no esperado dia - pacote volumoso conhecido como "jumbo" -, nas negociações de turno de trabalho da mulher que o inflexível dia da visita impõe, na troca de cartas e favores, no cuidado trocado de crianças vizinhas numa noite de fim de semana, etc. A ampla circulação dessa prisão-passado-presente faz da prisão-futuro daquela prisão-possibilidade onipresente - uma possibilidade mais freqüente, mais conhecida, esperada e esperável. Essa, uma prisão-virtualidade que não necessariamente paralisa, aterroriza, dissuade, mas que por tanta familiaridade, entra no cálculo do futuro, que é quase mensurável em seus efeitos com alguma antecedência, que pode ser vista por alguns como uma etapa da vida senão necessária, ao menos inelutável, e por muitos outros como algo naturalizado, "normal" para quem escolher seguir um determinado caminho na vida.

Esse primeiro conjunto de evidências advém da experiência de Iniciação Científica ${ }^{1}$, quando transcrevi e editei uma série de entrevistas feitas em bairros periféricos da cidade de São Paulo, e que me fizeram perceber a importância da prisão como ponto de entrecruzamento de trajetórias em determinados territórios urbanos periféricos. Essa constatação aparecia sob vários registros. Em primeiro lugar, era possível entrar em contato com um número significativo de trajetórias de vida marcadas pela experiência penitenciária, seja de egressos do sistema prisional, seja de parentes próximos ou amigos de presos, que passavam (ou não) pela experiência periódica da visitação. Em segundo lugar, pelos relatos era possível verificar que a experiência carcerária mobilizava uma complexa rede de apoio, que ora garantia itens básicos de sobrevivência para famílias que tiveram seus provedores presos, ora viabilizava recursos para a visitação, para pagar advogados, e para garantir a montagem e o envio do "jumbo". Em terceiro lugar, era possível ficar sabendo do impacto local, na forma de tensão e preocupação com filhos, maridos, parentes e amigos, das rebeliões prisionais,

\footnotetext{
${ }^{1}$ Desenvolvida entre 2004 e 2006, sob orientação da Profa. Dra. Vera da Silva Telles, nos quadros da pesquisa "Cidade e trabalho: mobilidades ocupacionais e seus territórios" (CNPq, 2003-2006).
} 
grandes e pequenas, que, àquela altura, já eram freqüentes em São Paulo. Finalmente, também era possível ficar sabendo da marcante presença de pessoas envolvidas no "mundo do crime" em estreita relação com presos, e inscritas nas redes sociais que conformavam a sociabilidade cotidiana daqueles bairros periféricos paulistanos. Foi esse conjunto de indícios da existência de redes sociais estruturadas e mobilizadas em torno da prisão, envolvendo um significativo número de agentes, que serviu como um dos pontos de partida para esse trabalho.

O segundo conjunto de evidências, a segunda pista se cruza com a primeira nessa estruturação de um "mundo do crime" que passa pela prisão e se articula com as redes vicinais de bairros periféricos. Trata-se nomeadamente da estruturação da facção prisional Primeiro Comando da Capital (PCC) para além dos limites prisionais, da sua capilaridade em diferentes territórios urbanos, que se expressa espetacularmente em eventos de grande repercussão midiática como ações de resgate, roubos milionários, grandes esquemas de tráfico de drogas e armas, ou nos "Ataques do PCC" de maio de 2006. Mas, também, um transbordamento que é perceptível no discreto financiamento de cestas básicas a familiares de presos, no pagamento de advogados, na circulação de uma linguagem, de um conjunto de códigos de conduta, de protocolos sociais, que vão compondo os repertórios de um lado e outro das muralhas. Essas evidências de diversificadas práticas externas de um grupo que se estrutura no interior da prisão, indubitavelmente, também colocam o problema de um transbordamento da prisão para fora de seus limites.

No cruzamento dessas duas pistas iniciou-se um percurso de investigação acerca da presença da prisão para além dos seus limites materiais ou institucionais, e, de imediato, uma questão se impôs. Num breve e prévio levantamento de dados foi possível perceber que uma formulação é amplamente aceita e difundida para expressar o sentido do transbordamento da prisão: a prisão se faz presente além de seus limites físicos sempre desestruturando vínculos sociais, sociabilidades e formas de vida, ou seja, a presença "externa" da instituição prisional é pensada nos termos de efeitos imediatos e negativos que impõe sobre os grupos e territórios que alcança, seja sob o signo da “desestruturação familiar", seja sob o signo do "crime organizado". Por um lado, diz-se que algo de bom e desejável é destruído; por outro, que algo de nefasto é construído. Ainda que não sejam discursos congruentes, é sob uma mesma racionalidade que se 
formula o problema. ${ }^{2}$ Porém, os conjuntos de evidências encontrados - principalmente a primeira pista - pareciam apontar para o sentido contrário dessa visão geral: o que chamava a atenção era exatamente a dimensão estruturante da presença prisional naqueles territórios periféricos, os vínculos que eram criados, mantidos, reconfigurados em torno de uma prisão-passado-presente-futuro que parecia se normalizar e se rotinizar no bairro. Se a chegada da prisão implicava - num primeiro momento ou na escala de uma residência - num impacto desestruturante do ambiente familiar e da rede vicinal, sua presença continuada parecia implicar em processos mais amplos de reestruturação de práticas, discursos e vínculos sociais, que não poderiam ser satisfatoriamente descritos em termos estritamente negativos.

Por outro lado, Foucault (1996), já em "Vigiar e Punir", advertia para a importância de não se analisar os efeitos de poder das instituições punitivas como meramente negativos. Sua análise da positividade e produtividade do poder disciplinar - que se corporifica no sistema carcerário, mas que se estende por outros territórios - também me servia de referência para entrever algo sendo produzido exatamente onde de modo reiterado se denunciava a destruição. Nestes termos, o ponto de partida da pesquisa - a evidência de que a prisão estrutura um campo de agentes, práticas e discursos muito além de seus limites institucionais - desdobra-se numa espécie de ponto cardeal que orienta todo o percurso de investigação.

O aprofundamento da pesquisa bibliográfica permitiu-me perceber que esse tipo de problemática não se impõe somente no contexto paulista ou brasileiro, mas entra em ressonância com um importante debate teórico aberto acerca da redefinição do lugar da prisão na sociedade ocidental. Debruçando-se, principalmente, sobre os contextos britânico e estadunidense, Garland (1999, 2001, 2005) estabelece alguns marcos referenciais inescapáveis para essa problematização. Esse autor coloca no foco de sua reflexão os efeitos societários das mudanças recentes nas políticas de controle do delito e justiça penal que, desde a década de 1970, são progressivamente regidas por um maior

\footnotetext{
${ }^{2}$ É importante considerar que cada formulação tem suas próprias implicações. Por um lado, o discurso da "desestruturação familiar" associa-se a demandas assistenciais e de promoção do bem-estar das pessoas direta e indiretamente afetadas pelo encarceramento, enquanto o discurso do "crime organizado" vem associado a demandas de confrontação, repressão e eliminação de uma ameaça considerada iminente. Para além dos desdobramentos práticos e discursivos de cada formulação, o que se pretende ressaltar é que ambas as formulações comungam uma mesma concepção negativa do transbordamento da prisão.
} 
rigor punitivo, resultando no que chama de encarceramento em massa. ${ }^{3}$ Sob essa nova cultura punitiva - cultura do controle, nos termos de Garland (2005) - a prisão vai se tornando uma instituição socializadora de amplos setores da população, de negros e latinos nos Estados Unidos, de imigrantes estrangeiros na Europa. Melhor compreender os significados dessa socialização penitenciária ampliada, segundo o autor, é tarefa premente da investigação sociológica. Diversos autores corroboram essa preocupação, muitos se dedicando a explorar as causas desse processo - como Zimring e Hawkins (1991), Christie (1993), Wacquant (2007), Mauer (2001), Tonry (1999), Kuhn (2001), Downes (2001), entre outros -; e outros se debruçando sobre suas conseqüências - entre eles, Braman (2003), Comfort (2003, 2007), Mauer e Chesney-Lind (2002), Travis e Waul (2003), etc.

Cunha (2002), por sua vez, trabalha com questões que apresentam outros paralelos importantes com os conjuntos de evidências que serviram de ponto de partida para esse percurso investigativo. Essa autora desenvolve a tese de erosão das fronteiras entre bairros e prisões, estabelecendo alguns marcos para a reflexão acerca do redefinido lugar social da prisão, bem como da dinâmica de estruturação de um campo de agentes, práticas e discursos articulados num bairro em função da prisão (e também numa prisão em função do bairro). Segundo a antropóloga portuguesa, uma recente extensão do mercado varejista da droga em determinados bairros periféricos de Lisboa se deu através da mobilização de redes familiares e vicinais, que há muito se articulavam ancoradas em práticas de sobrevivência, desenvolvidas nos percalços da informalidade. A introdução do mercado da droga no repertório de práticas locais implicou numa importante alteração na economia política dos ilegalismos populares lisboetas, bem como, simultaneamente, no desenvolvimento de um novo perfil de políticas criminais de repressão ao tráfico, que passa a focar a atuação policial nesses territórios. $\mathrm{O}$ resultado previsível é o encarceramento progressivo de agentes de uma mesma rede familiar e vicinal, rede que se desestrutura, mas se reestrutura e se atualiza entre o bairro e a prisão. Nestes termos que a autora descreve o processo de erosão das fronteiras entre bairros e prisões, e problematiza uma redefinição da experiência carcerária, que vai

\footnotetext{
${ }^{3}$ Processo, segundo Garland, dotado de duas características básicas: 1 - a guinada ascendente e sem precedentes das taxas de encarceramento; e 2 - a concentração social dos efeitos desse aumento em determinados grupos populacionais.
} 
perdendo, em grande medida, o caráter estigmatizante que sempre teve, para tornar-se cada vez mais um expediente "normal" e previsível na vida daquelas populações.

As referências em Foucault, Garland e Cunha foram fundamentais para que delimitasse um plano inicial de pesquisa, uma direção a tomar. Projetei uma pesquisa de caráter exploratório, fundada na coleta de histórias de vida de pessoas que estabeleceram, em algum momento, um contato direto ou mediado com o mundo prisional, residentes de algum bairro periférico no qual se verificasse altos e crescentes índices de encarceramento. $\mathrm{O}$ objetivo principal era prospectar os processos e dinâmicas de estruturação de um campo de agentes, práticas e discursos pautados pela prisão nessa localidade, estruturação que, por sua vez, era entendida como um dos efeitos difusos, produtivos e positivos, do processo de massificação do encarceramento - fenômeno também verificável em São Paulo.

Mas isso não era tudo, a estratégia inicial desenvolvida nas primeiras etapas da pesquisa ainda envolvia outros dois aspectos fundamentais, que visavam cuidar para que o percurso realizado permanecesse, o mais fielmente possível, orientado pela presença da prisão no bairro, e pelas estruturações sociais que pautava, e não pela presença do "mundo do crime" e suas próprias estruturações - um desvio, então, imaginado existente e considerado iminente, dado o entrecruzamento contínuo dessas duas sendas, certamente interligadas, mas não necessariamente redutíveis uma à outra.

A primeira precaução metodológica estratégica foi o estabelecimento dos vasos comunicantes que conectam o bairro à prisão como foco primordial de prospecção de informações no decorrer do trabalho de campo. Em outras palavras, os processos de estruturação das visitas, dos "jumbos", a troca de cartas, os procedimentos de recepção de presos em saídas temporárias, ou de egressos do sistema - ou seja, tudo o que implicasse uma efetiva comunicabilidade entre o mundo prisional e o bairro, e ao redor do que se estruturaria um campo de agentes, práticas e discursos - eram vistos como fatores determinantes na conformação e consolidação da presença prisional no bairro, e a eles se deveria prestar maior atenção no decorrer da pesquisa. É sabido que esses vasos comunicantes sempre existiram, que a prisão sempre se caracterizou por certo grau de porosidade, mas entendia-se que os vasos comunicantes se revestiam de maior importância analítica nesse contexto punitivo reconfigurado, no qual a prisão se torna instituição socializadora de determinados (e amplos) grupos populacionais. 
A segunda precaução metodológica foi o estabelecimento de uma estratégia comparativa para melhor identificar as estruturações sociais que se dão a partir da presença da prisão no bairro. Num contexto como o paulista, parecia insuficiente pautar o exercício investigativo nos vasos comunicantes, uma vez que se sabia haver uma ampla incidência da facção prisional na dinâmica estruturante desses vasos. A crescente importância da facção prisional na gestão urbana dos "negócios do crime", e suas múltiplas intersecções com as redes vicinais de bairros periféricos pareciam misturar demasiadamente o que poderia ser visto como efeitos estruturantes da presença prisional e do "mundo do crime" no bairro. A saída encontrada foi procurar empreender a mesma pesquisa em contextos sociais distintos, dotados de diferenciadas dinâmicas criminais principalmente algum em que não se verificasse a existência de algo como o PCC -, mas que se aproximassem sob uma mesma tendência de incremento do encarceramento. Por contraste, imaginava-se poder melhor identificar, isolar e caracterizar o campo de agentes, práticas e discursos que se estrutura a partir da prisão e de seu incremento numa dada localidade, distinguindo-o das estruturações societárias próprias ao "mundo do crime".

Como se pode imaginar - principalmente em se tratando de uma proposta sociológica de caráter exploratório - as dificuldades de um estudo comparativo se situam mais nas possibilidades materiais do que na justificação teórica. Realizar pesquisa de campo em contextos sociais suficientemente distantes exige recursos que são difíceis de um pesquisador iniciante captar. Não obstante, foi-me concedido o privilégio de contar com uma bolsa de estudos integral oferecida pelo Ministério de Assuntos Exteriores da Espanha, para realizar atividades de pesquisa durante um ano nesse país. ${ }^{4}$ De tal modo, o estudo do campo de agentes, práticas e discursos, que se estrutura num bairro ao redor dos vasos comunicantes que o conectam à prisão, inicia-se num campo distante e desconhecido: a região metropolitana de Barcelona.

\footnotetext{
${ }^{4}$ Simultaneamente à aprovação no processo seletivo do Programa de Pós-Graduação em Sociologia da Universidade de São Paulo (PPGS-USP), fui beneficiado pela Agência Espanhola de Cooperação Internacional, do Ministério de Assuntos Exteriores da Espanha (MAE-AECI), com uma bolsa integral (becas-MAE) para a realização do Máster Oficial em Investigação Etnográfica, Teoria Antropológica e Relações Interculturais do Departamento de Antropologia Social, da Universidade Autônoma de Barcelona (UAB). De tal modo, ainda em setembro de 2007, fui para Barcelona, onde imediatamente iniciei as atividades discentes previstas no curso e desenvolvi um projeto de pesquisa que adaptava as questões levantadas no projeto apresentado na USP para o contexto espanhol. Em setembro de 2008, apresentei o relatório de pesquisa - intitulado "Entre la Calle y la Cárcel: una investigación etnográfica exploratoria sobre el flujo carcelario-urbano que pasa por Barcelona" (GODOI, 2008a) - a banca avaliadora composta pelos professores Verena Stolcke, Montserrat Ventura e Alex Coello.
} 
A despeito da manutenção de um mesmo ponto cardeal no horizonte da pesquisa e de tantas precauções metodológicas, a viagem à Catalunha, seguramente, representou um primeiro desvio no percurso da investigação. Nos oito meses de trabalho de campo desenvolvido na Europa encontrei muita dificuldade para "entrar" nas redes de sociabilidade que se conformam num bairro em função da prisão. Na tentativa de contornar os obstáculos que se interpunham, procurei acionar o que entendia como mediadores estratégicos entre o mundo público e prisional - principalmente acadêmicos especialistas e profissionais do sistema penitenciário - imaginando que por meio deles poderia encontrar as pistas necessárias para alcançar a projetada unidade de análise, um bairro com altos e crescentes índices de encarceramento. A tática de exploração de campo se mostrou proveitosa - em quatro meses iniciava trabalho de campo em Sant Ildefons, bairro popular de uma cidade satélite de Barcelona. Porém, o tempo dedicado a contornar os obstáculos foi muito maior do que se imaginava. Mesmo no bairro, e já em contato direto com egressos e familiares de presos, todo um tempo, uma caminhada, um contornamento foi necessário para se ganhar a confiança dos interlocutores e chegar a abordar os problemas que estavam no foco da pesquisa, de tal modo que quando o campo estava relativamente bem preparado, já era tempo de voltar ao Brasil.

Em São Paulo, dificuldades análogas se impuseram no percurso. Mesmo num contexto social mais bem conhecido, os 14 meses de pesquisa de campo também se mostraram insuficientes para a imaginada inserção num bairro com elevados índices de encarceramento. Desse modo, também em São Paulo, a maior parte do percurso de campo foi dedicada ao contornamento dos obstáculos que se interpunham a uma aproximação mais efetiva dos agentes, práticas e discursos que se estruturam ao redor da prisão num bairro.

A conclusão inescapável que se segue desses tortuosos percursos é que uma investigação sobre a prisão é tarefa das mais delicadas e complexas, que nem um desenho de pesquisa razoavelmente preciso, e nem as precauções metodológicas consideradas mais estratégicas, são inteiramente suficientes quando se deixa o planejamento e se parte para a caminhada. Em suma, é possível concluir que a pesquisa sobre a prisão, principalmente se voltada para a sua "presença" exterior, suas implicações societárias externas, envolve uma série de questões e dificuldades que são, elas mesmas, dignas de um detida problematização sociológica. 
De qualquer maneira, ainda que não se tenha alcançado o ponto imaginado, o percurso, por si só, impõe questões para a reflexão. Na tentativa constante de chegar ao bairro, todo um campo de agentes, práticas e discursos que se estruturam, em ambiente aberto, ao redor e através da prisão, pôde ser explorado e mais bem conhecido, tanto em Barcelona, quanto em São Paulo. Para abordá-lo, restava ajustar o foco da investigação ou, seguindo na metáfora do viajante, recuperar os desvios e contornos percorridos, pontuando-os num novo mapa, com outros marcos referenciais e outros pontos cardeais.

Em primeiro lugar, deve-se admitir que parte significativa da pesquisa não se deu junto aos vasos comunicantes que ligam a prisão a um determinado território periférico urbano, mas sim junto a mediadores que, pela natureza de suas atividades, ligam a prisão a diversas outras dimensões do mundo social. Trata-se de operadores do direito, profissionais da saúde, educação, e segurança penitenciária, de militantes de direitos humanos, assistentes sociais, voluntários de organizações não-governamentais, estudantes e pesquisadores de universidades e centros de pesquisa. Estes, mesclados a egressos, familiares e amigos de presos se articulam num campo político que se estrutura em torno das prisões, e que ultrapassa suas delimitações jurídicoinstitucionais. Em outras palavras, esse conjunto de agentes estrutura ao redor da prisão um campo de contínua problematização, no qual múltiplas práticas, discursos, saberes, críticas, resistências, invenções políticas circulam, defrontam-se, entram em disputa conformando o que Foucault $(1980,1987)$ chamaria de dispositivo carcerário. Portanto, em segundo lugar, deve-se admitir que o foco da pesquisa transitou dos efeitos societários territorializados do aumento do encarceramento para uma abordagem analítico-descritiva de algumas peças, mecanismos, funções e disfunções do dispositivo carcerário contemporâneo. Faz-se necessário, desde já, delimitar minimamente o que se entende por esse dispositivo.

Foucault trabalha a noção de dispositivo em diferentes ocasiões sem, no entanto, engessá-la num conceito de postulado definitivo. Em "Vigiar e Punir" (1996), debruçase sobre o dispositivo disciplinar; em "Segurança, Território e População" (2006), sobre o dispositivo de segurança; e em "História da Sexualidade I" (1987), sobre o dispositivo da sexualidade. Numa entrevista acerca dessa última obra - publicada em "Microfísica do Poder" (1980) - é possível encontrar uma de suas mais claras formulações sobre essa noção estratégica que atravessa boa parte de sua produção: 
"Através deste termo tento demarcar, em primeiro lugar, um conjunto decididamente heterogêneo que engloba discursos, instituições, organizações arquitetônicas, decisões regulamentares, leis, medidas administrativas, enunciados científicos, proposições filosóficas, morais, filantrópicas. Em suma, o dito e o não dito são os elementos do dispositivo. $O$ dispositivo é a rede que se pode estabelecer entre estes elementos. Em segundo lugar, gostaria de demarcar a natureza da relação que pode existir entre estes elementos heterogêneos. Sendo assim, tal discurso pode aparecer como programa de uma instituição ou, ao contrário, como elemento que permite justificar e mascarar uma prática que permanece muda; pode ainda funcionar como reinterpretação desta prática, dando-lhe acesso a um novo campo de racionalidade. Em suma, entre estes elementos, discursivos ou não, existe um tipo de jogo, ou seja, mudanças de posição, modificações de funções, que também podem ser muito diferentes. Em terceiro lugar, entendo dispositivo como um tipo de formação que, em um determinado momento histórico, teve como função principal responder a uma urgência. $O$ dispositivo tem, portanto, uma função estratégica dominante. Este foi o caso, por exemplo, da absorção de uma massa de população flutuante que uma economia de tipo essencialmente mercantilista achava incômoda: existe ai um imperativo estratégico funcionando como matriz de um dispositivo, que pouco a pouco tornou-se o dispositivo de controle-dominação da loucura, da doença mental, da neurose." (FOUCAULT, 1980, pp.137-138 - grifo meu)

Na seqüência da entrevista, Foucault segue explorando os processos característicos de um dispositivo, e para tanto recorre ao exemplo do dispositivo carcerário:

“Um primeiro momento é o da predominância de um objetivo estratégico. Em seguida, o dispositivo se constitui como tal e continua sendo dispositivo na medida em que engloba um duplo processo: por um lado, processo de sobredeterminação funcional, pois cada efeito, positivo ou negativo, desejado ou não, estabelece uma relação de ressonância ou de contradição com os outros, e exige uma rearticulação, um reajustamento dos elementos heterogêneos que surgem dispersamente; por outro lado, processo de 
perpétuo preenchimento estratégico. Tomemos o exemplo do aprisionamento, dispositivo que fez com que em determinado momento as medidas de detenção tivessem aparecido como o instrumento mais eficaz, mais racional que se podia aplicar a fenômeno da criminalidade. O que isto produziu? Um efeito que não estava de modo algum previsto de antemão, que nada tinha a ver com uma astúcia estratégica produzida por uma figura meta ou trans-histórica que o teria percebido e desejado. Este efeito foi a constituição de um meio delinqüente, muito diferente daquela espécie de viveiro de práticas e indivíduos ilegalistas que se podia encontrar na sociedade setecentista. O que aconteceu? A prisão funcionou como filtro, concentração, profissionalização, isolamento de um meio delinqüente. A partir mais ou menos de 1830, assiste-se a uma reutilização imediata deste efeito involuntário e negativo em uma nova estratégia, que de certa forma ocupou o espaço vazio ou transformou o negativo em positivo: o meio delinqüente passou a ser reutilizado com finalidades políticas e econômicas diversas (como a extração de um lucro do prazer, com a organização da prostituição). É isto que chamo de preenchimento estratégico do dispositivo." (Idem, 1980, p.138)

O dispositivo como um conjunto complexo, diferenciado, movediço, em aberto, desprovido de coerência interna, mas conformado por uma estratégia dominante, por uma urgência histórica imperiosa, e por tantas outras urgências e estratégias que vão se impondo, se justapondo, e se contrapondo.

Portanto, em terceiro lugar, é preciso deixar claro que não se quer pretender, a partir do percurso realizado nessa pesquisa, produzir uma analítica exaustiva - um mapa completo - do dispositivo carcerário contemporâneo. Trata-se, tão somente, de apresentar uma cartografia parcial, um mapa de percursos possíveis, trilhas abertas que passam pelo dispositivo carcerário, mas que também se conectam a outros campos de problematização, porque guiadas pelos contornamentos da busca de um bairro, pelas trilhas abertas pelos interlocutores que foram sendo encontrados nesse percurso, e por uma miríade de descobertas inerentes à prática de explorar um terreno desconhecido.

Finalmente, resta pontuar que, segundo o material coletado e esse outro jogo de referências, a proposta comparativa perde sentido. Os percursos em Barcelona e São 
Paulo, que para serem comparáveis eram para ser bem territorializados e paralelos, cruzaram-se num obstáculo comum, e desdobraram-se em outras questões e territórios. De tal modo, desde a perspectiva dos traçados que atravessam o dispositivo carcerário, as diferentes dinâmicas da criminalidade - imaginadas como uma espécie de desvio comprometedor na formulação original da pesquisa -, bem como as muito variáveis estruturações societárias prospectadas que emanam da prisão em territorialidades difusas, acabam por ser reinscritas nessa cartografia como marcos sinalizadores adicionais, como dados do campo de possibilidades que o dispositivo encerra (ou abre). Isto é, a pesquisa na Catalunha, ao invés de ajudar a isolar os efeitos societários do encarceramento em massa, acaba por ampliar o repertório de possibilidades de estratégias, agentes, discursos, práticas, conflitos e também de resistências que são conformáveis no dispositivo.

Eis os principais marcos do percurso geral que o presente trabalho procura expressar, e que deverão ser mais bem situados e qualificados no decorrer das próximas páginas. De todo modo, uma última marcação precisa ainda aqui ser feita: a despeito de tantos desvios, contornos e reavaliações de percurso, no horizonte figura o mesmo ponto cardeal: a indagação acerca dos processos de estruturação de um campo de agentes, práticas e discursos ao redor e através da prisão, para muito além de seus limites físicos ou institucionais.

Agora, resta indicar esquematicamente como essas questões se distribuem no trabalho. No primeiro capítulo - "Hipótese produtiva" - apresento o que chamei de ponto cardeal da pesquisa, a perspectiva teórica e analítica adotada, suas causas e circunstâncias. No segundo capítulo - "Massificação do encarceramento" -, depois de sistematizar alguns trabalhos e problemas que pautam a discussão sobre o aumento do encarceramento, realizo uma primeira aproximação aos contextos punitivos estudados. O terceiro capítulo - "Vasos comunicantes" - visa situar a escala do problema do transbordamento da prisão; explorar alguns dos vasos comunicantes e das estruturações societárias que promovem; e apontar os sentidos da passagem de foco do trabalho de campo dos vasos comunicantes para os mediadores. No quarto capítulo - "Percursos de campo" procuro explicitar o trabalho de campo realizado em Barcelona e em São Paulo, para esclarecer ao máximo as circunstâncias empíricas que levaram ao deslocamento no eixo da pesquisa. O quinto capítulo - "Uma abordagem (im)possível" - é o da realização da 
passagem, onde se problematizam as dificuldades experimentadas e a saída encontrada. No sexto e sétimo capítulos - "Uma cartografia do dispositivo carcerário catalão" e "Uma cartografia do dispositivo carcerário paulista" - exploro as configurações e alterações recentes no dispositivo carcerário operante em cada contexto estudado. No capítulo final, mais do que uma conclusão, um balanço do percurso realizado, uma sistematização dos avanços efetuados e de possíveis direções a seguir. 


\section{1 - Hipótese produtiva}

Nina ${ }^{5}$ mora com Kátia e Marcelinho. Nina é mãe de Ronaldo, Kátia é mulher dele e Marcelinho é filho. Ronaldo está preso há mais de dez anos. As duas se conheceram dentro da prisão, num dia de visita. Kátia, muito jovem e ainda grávida, desesperava-se por não ter condições de criar o filho que viria. Ronaldo igualmente, por mais que trabalhasse na penitenciária, sabia que o dinheiro que recebia seria insuficiente para garantir o sustento do primeiro filho. Nina, viúva e aposentada, assumiu a responsabilidade de colaborar na criação do neto enquanto o filho estivesse preso, chamou a nora para morar com ela. Juntas, durante a semana, as duas fazem o "jumbo" que uma delas levará para Ronaldo no dia de visita. No "jumbo" e também no prato de Marcelinho, arroz, feijão, macarrão que são doados por vizinhos solidários e conhecedores das dificuldades daquela família.

Aisa, como Marcelinho, foi concebida numa visita íntima, no interior de um presídio. Até os quinze anos de idade, cresceu tendo o pai dentro de uma prisão muito distante. Comemorou aniversários, brincou, fez amizades dentro de uma unidade prisional desde sempre. Cedo se acostumou a viajar para visitar o pai, a não falar sobre sua condição de encarcerado, a ocultar como pudesse, meias, cuecas, escovas de dente para presentear o pai dentro da prisão. Por mais que o pai estivesse preso e distante, a relação familiar era forte e, na medida do possível, saudável; ele sabia de tudo que se passava com ela, trocavam cartas e lembranças, viam-se freqüentemente, conversavam francamente, amavam-se. Enquanto seu pai esteve preso, ela sonhava com uma vida normal que viria com a sua libertação. Quando ele foi solto, o sonho não se concretizou, de modo que aquela família carinhosa e unida a despeito da prisão, ruiu quando a prisão deixou de agir sobre ela. Na rua, ele envolveu-se em ilegalismos diversos, ficou violento com a mulher, ausente com a filha, sumiu, arrumou outra mulher, outros filhos, outra família, que passou a visitá-lo quando ele voltou a ser preso.

Eis alguns fragmentos de histórias de vida que mostram famílias se estruturando a despeito da prisão de um de seus componentes, ou mesmo a partir da prisão de um de

\footnotetext{
${ }^{5}$ Todos os nomes são fictícios.
} 
seus componentes. Famílias estruturadas ao redor da prisão, em cuja estruturação concorrem diversas gerações e também amigos e vizinhos, que vão, como podem, preenchendo as lacunas deixadas pela prisão do "chefe-provedor". Nesses ambientes familiares, a ausência do "chefe-provedor" é também a presença da prisão. A prisão presente e circulando o tempo todo, em lembranças doloridas (ou não), em conversas triviais, em contas (de dívidas, de dias), em sonhos feitos e refeitos a cada momento.

Foi no ambiente familiar que primeiro identifiquei indícios de estruturação de um campo social, promovido e produzido por uma instituição prisional que se faz cada vez mais presente. E foi a partir daí que me deparei com o problema do extravasamento da prisão, da prisão agindo fora dela, e isso de uma maneira imprevista, porque produtiva.

\section{1 - (D)efeitos}

Tão logo procurei referências e estudos que me ajudassem a compreender trajetórias e famílias como essas, deparei-me com formulações que podem ser exemplarmente sintetizadas na seguinte frase:

"cuando se encarcela a alguien, se produce un proceso de desestructuración familiar (...) hundimiento y destrucción de la familia, ruptura de las relaciones del hogar, ruptura de las relaciones con los componentes de la familia, o con alguno/a de ellos/as, problemas psíquicos graves, especialmente para la madre, o problemas de salud graves para otros miembros de la familia. A todas estas consecuencias se tiene que añadir, además, el rechazo social.” (OSPDH, 2006, pp.137-138)

Desestruturação, ruptura e estigma têm sido as noções fundamentais para a reflexão sobre a ação da prisão num ambiente familiar ou comunitário. Goffman (1988) lançou as bases para esse campo de problematização - em "Estigma: notas sobre a manipulação da identidade deteriorada", originalmente publicado em 1963 -, ao discutir o efeito contaminador do estigma de uma pessoa sobre outra que lhe é próxima. Os efeitos deletérios da ruptura de laços familiares e da estigmatização de familiares de 
presos é discutido e desdobrado, por exemplo, no trabalho de Pueschel e Moglia (1977), "The effects of the penal environment on familial relationships". No Brasil, ainda que escassa a teorização sobre essa questão, é possível identificar trabalhos que desenvolvem essa mesma perspectiva sobre o tema, como o de Miyashiro (2006), "Filhos de presidiários: um estudo sobre estigma."

Já no contexto estadunidense, Comfort $(2003$, 2007) formula a hipótese de "prisionização secundária", como um dos processos que afetam principalmente as mães, esposas e namoradas de presos que continuamente passam pela experiência de visitação em uma unidade prisional. A autora analisa a dinâmica social da visitação num presídio de segurança máxima da Califórnia, destacando as alterações comportamentais e simbólicas que esse processo específico de socialização introduz na vida dessas mulheres.

Travis e Waul (2003) organizaram uma publicação dedicada ao tema dos efeitos do encarceramento em diferentes níveis, intitulada "Prisoners Once Removed: the impact of incarceration and reentry on children, families and communities". O livro é composto por três partes: na primeira são discutidos os impactos do encarceramento sobre o indivíduo que passa pela prisão; na segunda, os impactos sobre seus filhos e suas famílias; e na terceira, os impactos sobre as comunidades locais de onde saem e para onde voltam. Em todas as partes, segundo os editores, existe uma preocupação em avaliar como os serviços sociais, sanitários, educacionais e correcionais podem se integrar de uma maneira mais efetiva para melhor atender as necessidades de indivíduos, famílias e comunidades desestruturados pelo encarceramento.

Com uma abordagem menos programática, Mauer e Chesney-Lind (2002) organizaram o livro "Invisible Punishment: the collateral consequences of mass imprisonment", no qual, entre tantas questões sobre os efeitos do incremento do encarceramento, aparecem trabalhos que repõem a questão da desestruturação que o cárcere promove na organização familiar e comunitária. Braman (in MAUER e CHESNEY-LIND, 2002, pp.117-135), ao concluir o seu artigo intitulado "Families and Incarceration", resume a tônica mais ou menos compartilhada por esses estudos que se voltam para a questão das conseqüências mais amplas do encarceramento e de sua intensificação: 
"The overuse of incarceration harms the families of prisoners as much as, if not more than, the prisoners themselves. It does so not only through direct costs that families bear, but by restructuring families and by distorting and diminishing the relationships between family and friends. In these sense, the incarceration of an offender is not simply the sanctioning of an individual, but part of a broader corrosion of social bonds - bonds that sustain people, particularly people in difficult circumstances. And as these bonds are strained, the resources available to members of the family, both material and emotional, are also diminished. As a result, not only individual families suffer from the overuse of incarceration, but the extended networks of kinship and friendship that make up a community suffer as well." (BRAMAN in MAUER e CHESNEY-LIND, 2002, p. 135 - grifos meus)

A hipótese geral que subjaz nessa ordem de análises dos efeitos do encarceramento é a de que a prisão tem a desestruturação como efeito primordial: desestruturação individual, familiar e comunitária.

De toda forma, essa ordem de problematizações contrastava com o que mais vinha me chamando atenção nas trajetórias e famílias que pesquisava. As famílias de Marcelinho e Aisa seguramente enfrentavam diversos problemas, debilidades financeiras, afetivas, preconceito. Porém, não eram famílias propriamente destruídas, eram famílias singulares, diferentes, distantes de um padrão imaginado de família ideal, mas não destruídas. Rechaço social seguramente existia, mas existiam também pessoas solidárias que colaboravam no sustento da família. As relações entre mãe e filho, pai e filho(a), marido e mulher não eram relações contínuas, diárias, mas não se pode dizer que fossem relações rompidas.

Essa bibliografia parecia-me por demais taxativa: a prisão impõe defeitos num ambiente familiar; enquanto os relatos como os de Nina e Aisa, levavam-me a crer que a prisão impõe efeitos, que podem ser dolorosos, desagradáveis, mas que não são absolutamente destruidores, podendo ser também reestruturantes, produtivos, e num sentido muito preciso. O vínculo entre Nina e Katia foi produzido na prisão, o cotidiano delas de manufatura de "jumbo" e visita semanal é produzido pelo encarceramento de Ronaldo; as próprias existências de Marcelinho e Aisa, no limite, foram também produzidas na prisão; como também o vínculo afetivo entre Aisa e seu pai foi produzido e mantido só 
enquanto ele esteve preso. São diversas as produções que a ação da prisão impõe num círculo familiar, para descrevê-la meramente como destruição, corrosão, etc.

Suspendendo, ainda que provisoriamente, a hipótese da desestruturação familiar como efeito primordial da prisão, esta passa a aparecer como um componente mais da socialização de famílias como as de Marcelinho e de Aisa. E nessa ação socializadora do cárcere para além de seus limites que procurava focar a investigação. De toda forma, se aquela perspectiva parecia prevalecer, cabia-me aprofundar o estudo sobre o processo de socialização que o cárcere promove, identificando e compreendendo as matrizes analíticas que faziam ver a destruição onde estava vendo produção.

\section{2 - Prisionizações}

A especificidade da socialização prisional constitui um tema caro à teoria social, tanto que se lhe atribuiu um nome próprio: prisionização. O termo prisionização aparece pela primeira vez na obra de Clemmer (1958), "The Prison Community", publicada originalmente em 1940. Nesse trabalho, o autor sintetiza aspectos estruturantes da cultura prisional e atenta para os meios pelos quais essa cultura conforma atitudes nos indivíduos que passam pela prisão. A idéia de prisionização é desenvolvida com referência à noção de "assimilação". A assimilação é uma variante da socialização na medida em que supõe que um indivíduo previamente socializado num determinado contexto pode ser assimilado a outro, se passa por um segundo processo socializante:

“(...) the term assimilation describes a slow, gradual, more or less unconscious process during which a person learns enough of the culture of a social unit into which he is placed to make him characteristic of it" (CLEMMER, 1958, pp.298-299).

Segundo Clemmer, da mesma forma que o processo de assimilação de imigrantes nos Estados Unidos poderia ser chamado de "americanização", a assimilação de indivíduos no ambiente prisional poderia ser nomeada de prisionização. $O$ processo de prisionização é experimentado, em alguma medida, por todo homem que passa por uma 
penitenciária, implicando numa reinterpretação geral da vida. Através dele, novos significados são atribuídos a noções fundamentais que organizam a experiência humana, como o abrigo, o vestuário, a alimentação, o trabalho, etc.; elementos fundamentais da vida, que na prisão invariavelmente passam a ser administrados por outrem.

O autor ainda apresenta fatores universais que caracterizam o processo de prisionização, como um catálogo dos principais efeitos do encarceramento sobre o indivíduo preso: 1 aceitação de uma posição social inferior; 2 - progressiva acumulação na memória de fatos concernentes à organização prisional; 3 - desenvolvimento de novos hábitos de alimentação, vestuário, trabalho e sono; 4 - adoção da linguagem local; 5 - o reconhecimento de que necessidades fundamentais não podem ser satisfeitas no devido ambiente; e 6 - o desejo de conseguir um bom trabalho no interior do presídio. $\mathrm{Na}$ medida em que se verificam esses fatores gerais nas atitudes de um preso, é possível identificá-lo como um membro da "comunidade prisional", que foi socializado na cultura da prisão.

Clemmer sustenta que existem graus de prisionização, e múltiplos fatores que determinam a velocidade e o alcance do processo para cada indivíduo - como a duração da pena, os atributos de personalidade, o grau de contato com elementos do ambiente externo à prisão, e a integração ou não a grupos de poder no interior da unidade. Interessava-lhe especialmente os casos de prisionização nos seus graus mais altos, pois, segundo ele, é nesse estágio que se aprofundam as atitudes anti-sociais e se desenvolve uma ideologia criminal no indivíduo.

Sykes (1958) é outro autor que discute a especificidade do processo de socialização no interior da comunidade prisional. Em "Society of Captives: a study of a maximum security prison", o autor analisa as dinâmicas formal e informal de interação dos presos entre si, e destes com o conjunto de funcionários, num estudo que se aproxima da análise da cultura prisional proposta por Clemmer. Mas, por sua vez, para qualificar o processo de socialização dos internos, Sykes privilegia outros elementos e processos estruturais. Segundo esse autor, a cultura da prisão pode ser mais bem descrita pela enumeração e análise das privações que a vida prisional implica. Descrevendo o que chama de "dores do encarceramento" - que dão ensejo à elaboração de práticas e significados sociais que são próprios ao ambiente - Sykes apresenta os traços característicos da cultura prisional e do processo de prisionização. Segundo esse autor, 
as privações de liberdade, de bens e serviços, de relacionamentos heterossexuais, de autonomia e de segurança constituiriam as bases estruturais do desenvolvimento de uma cultura e identidade específicas à prisão.

Outro estudo que se dedica a analisar a conformação do sujeito a partir das privações que lhe são impostas é "Manicômios, Prisões e Conventos", de Goffman (1974), publicado pela primeira vez em 1961. Ainda que esse autor não se proponha a analisar especificamente o processo de socialização na prisão, esse estudo estabelece importantes marcos teóricos e analíticos que foram posteriormente mobilizados em estudos sobre a prisionização. Goffman propõe uma análise da socialização em "instituições totais", que, segundo ele, se caracterizam como "um local de residência e trabalho onde um grande número de indivíduos com situação semelhante, separados da sociedade mais ampla por considerável período de tempo, levam uma vida fechada e formalmente administrada." (GOFFMAN, 1974, p.11) As instituições totais podem compreender desde o monastério religioso, o hospital psiquiátrico até a prisão, já que em todos eles:

“Em primeiro lugar, todos os aspectos da vida são realizados no mesmo local e sob uma única autoridade. Em segundo lugar, cada fase da atividade diária é realizada na companhia imediata de um grupo relativamente grande de outras pessoas, todas elas tratadas da mesma forma e obrigadas a fazer as mesmas coisas em conjunto. Em terceiro lugar, todas as atividades diárias são rigorosamente estabelecidas em horários, pois uma atividade leva, em tempo predeterminado, à seguinte, e toda a seqüência de atividades é imposta de cima, por um sistema de regras formais explícitas e um grupo de funcionários. Finalmente, as várias atividades obrigatórias são reunidas num plano racional único, supostamente planejado para atender aos objetivos oficiais da instituição." (GOFFMAN, 1974, p.17-18)

Segundo Goffman, o ingresso numa instituição total impõe uma série de desvios na “carreira moral" do indivíduo, que são experimentados como degradantes, e constituem "mortificações do eu". Por "carreira moral”, o autor faz referência ao processo geral de socialização, que se desenvolve na constante interação do indivíduo no interior de 
diferentes grupos sociais. ${ }^{6}$ Já as "mortificações do eu" podem ser entendidas como mutilações que são impostas numa identidade previamente constituída. Para o autor, a primeira mutilação do eu que uma instituição total impõe é a própria barreira que separa o interno do meio externo, impossibilitando que o individuo se mantenha atualizado sobre o que acontece na sociedade em geral, operando uma espécie de "desculturação" e "destreinamento" para a vida em liberdade. A segunda mutilação é a perda do nome, e sua substituição por um número e/ou apelido, geralmente percebidos como humilhantes. A perda absoluta de espaços e momentos de intimidade, a submissão a procedimentos humilhantes, a perda de controle sobre as atividades são outras das mutilações destacadas por Goffman.

A essas mutilações, no eu mortificado, sobrepõem-se uma série de ajustes secundários que visam a adaptação do sujeito à vida na instituição, de forma que se possa conservar um mínimo de domínio sobre o meio. Sistemas informais de comunicação, estratégias para obtenção de satisfações proibidas, ou mobilização de meios proibidos para a obtenção de satisfações permitidas são alguns elementos que caracterizam esse sistema de ajustes. Diferentemente de Clemmer, que diferencia o processo de prisionização em termos de grau quantitativo e ritmo, Goffman identifica diferentes possibilidades de desenvolvimento de ajustes secundários, conformando diferentes sujeitos adaptados ao ambiente institucional. A adaptação pode rumar ou para uma conversão absoluta do sujeito, que passa a se identificar com os objetivos institucionais; ou para uma acomodação passiva e utilitária, que visa o aproveitamento máximo dos benefícios possíveis no ambiente interno; ou para uma recusa intransigente de tudo o que a instituição obriga e oferece; ou para uma alienação profunda, que torna o individuo indiferente a quase tudo que não lhe toque o corpo.

Clemmer, Sykes e Goffman demarcam o campo de problematização do processo de socialização no interior do ambiente prisional, e baseando-se neles ou se opondo a eles que toda uma bibliografia sobre a prisionização se desenvolveu. Para citar alguns exemplos é possível mencionar os trabalhos de Wheeler (1961), "Socialization in correctional communities"; de Edwards (1970), "Inmate adaptations and socialization in the prison"; e de Kaminski (2003), "Games Prisoners Play: allocation of social roles in a total institution". No Brasil, Thompson (2002) - em “A Questão Penitenciária",

\footnotetext{
${ }^{6}$ Para uma discussão mais detida sobre carreira moral, ver: GOFFMAN (1988).
} 
originalmente publicado em 1976 - e Ramalho (2002) - com "O Mundo do Crime: a ordem pelo avesso", publicado pela primeira vez em 1979 - são pioneiros nesse debate acerca da socialização prisional.

Já em "Manicômios, Prisões e Conventos", Goffman expandia o campo de problematização sobre a socialização em instituições totais para o corpo de funcionários da instituição, discutindo as especificidades desse tipo de trabalho sobre seres humanos. ${ }^{7}$ O psicólogo Zimbardo (1973, 2004), a partir do experimento que conduziu em 1971 na Universidade de Stanford ${ }^{8}$, aprofunda-se na reflexão sobre a ação do meio na constituição dos sujeitos, dando especial atenção para as transformações na personalidade de indivíduos que ocupam posições de poder num ambiente prisional. ${ }^{9}$ Ainda sobre a socialização dos profissionais do encarceramento podem ser citados os trabalhos de Duffee (1974), "The correctional officer subculture and organizational change"; de Jacobs e Retsky (1975), "Prison Guard"; e de Ellis (1979), “The prison guard as a carceral Luddite: a critical review of the MacGuigan Report on the penitentiary system in Canada".

A prisionização de funcionários de prisão, portanto, também constitui uma linhagem dessa ampla bibliografia sobre a socialização prisional. No Brasil, Thompson já indicava a importância de a reflexão sobre as instituições penitenciárias abarcar esse aspecto específico. A psicóloga Lopes (1998) abordou o tema em sua pesquisa de mestrado; e Chies et. al. (2005), retomando sugestões de Thompson, desenvolveram uma pesquisa específica sobre a prisionização de funcionários num presídio de Pelotas, Rio Grande do Sul.

A passagem para análises da socialização prisional de familiares de presos prisionização secundária, nos termos de Comfort - é uma derivação, uma continuidade, uma ampliação de toda essa discussão acima apontada. $\mathrm{O}$ privilegiar na análise os aspectos desestruturantes da ação institucional sobre as famílias de presos deriva da maneira de se conceber a ação da prisão sobre os próprios presos. "Dores do encarceramento" ou "mortificações do eu" conformam um substrato de desestruturação

\footnotetext{
${ }^{7}$ Ver: GOFFMAN (1974), pp.69-83.

${ }^{8}$ Experimento de simulação de uma prisão, com voluntários desempenhando os papéis de presos e vigilantes.

${ }^{9}$ Os resultados do experimento estão disponíveis na internet, ver: http://www.prisonexp.org/ (Consulta feita em maio de 2010).
} 
de uma "carreira moral" - do processo de constituição de uma individualidade - à qual, só posteriormente se acresceriam "ajustes secundários", esboços e tentativas de reestruturação identitária. Mas esboços que são sempre insuficientes para reparar uma identidade que é fundamentalmente desfigurada pela prisão. Assim se concebe a socialização pela prisão, seja de internos, seja de funcionários de prisão, seja de familiares de presos.

Sem desconsiderar a importância desse campo de problematização, é preciso ponderar que existem outras formas de se pensar a prisão, que poderiam oferecer outras matrizes de interpretação para a ação da instituição prisional para além de seus limites físicos.

\section{3 - A hipótese produtiva}

Tão relevante quanto essa literatura sobre os diversos efeitos desestruturantes da prisão é um campo de problematização que procura indagar à prisão sobre sua especificidade frente a outras formas de punição, sobre suas funcionalidades estratégicas, suas causas obtusas e fundamentais. Uma tradição que se alinha à anterior ao verificar que a prisão não é exatamente o "instituto de regeneração" que apregoa ser, mas que se afasta daquela ao empreender outros percursos analíticos a partir dessa constatação. Nesse outro plano de referências, questões sobre o que a prisão desestrutura, como a prisão reprime ou distorce individualidades e grupos sociais são deslocadas, cedendo lugar a indagações sobre o que produz a punição em forma de prisão, como a punição em forma de prisão funciona e como ela conforma individualidades e grupos sociais. Opera-se assim uma passagem de foco dos efeitos desestruturantes da prisão para os processos estruturantes da punição (em forma de prisão e/ou não). De um lado, o trabalho de Rusche e Kirchheimer (1984), de outro, o de Foucault (1996) constituem os alicerces desse segundo campo.

Rusche e Kirchheimer - em "Punição e Estrutura Social", originalmente publicado em 1939 - sustentam que para analisar sociologicamente um sistema punitivo é necessário, em primeiro lugar, suspender o nexo explicativo entre delito e pena, de modo que a 
forma da punição numa determinada época possa ser analisada com referência às relações positivas que mantém com as estruturas sociais e econômicas nas quais se insere. Ou seja, ao invés de indagar sobre o que a prisão busca reprimir - sobre sua relação negativa com o delito - questionar sobre o que a prisão busca operar - sua relação positiva com o sistema produtivo.

A forma específica da punição num determinado período histórico, segundo esses autores, não seria uma função da criminalidade, de suas formas e intensidades, mas antes, uma função do grau de desenvolvimento do sistema produtivo, das condições de oferta e demanda de força de trabalho, e das condições de vida das classes mais pobres de uma população. De acordo com eles, o desenvolvimento econômico de uma sociedade e as oscilações entre oferta e demanda de mão de obra determinam variações no valor atribuído à própria vida humana, condicionando as escolhas por métodos punitivos mais ou menos severos. Em "Punição e Estrutura Social", a análise da variação das formas de punição abarca o processo de desenvolvimento econômico e social desde a Baixa Idade Média até as tendências observáveis nos regimes totalitários nazi-fascistas do século XX. Para explicitar as linhas gerais do argumento dos autores de uma maneira esquemática, basta indicar que o estudo demarca três grandes períodos no desenvolvimento da punição. Um primeiro período caracterizado por um regime de produção feudal, no qual se verifica um excedente de mão de obra e uma conseqüente baixa valorização da vida humana. Nesse período, aqueles criminosos que não tinham propriedades eram punidos de um modo extremamente cruel, com variados tipos de penas corporais e frequientemente com a pena capital. O segundo período é o mercantilista, da empresa colonial e dos primeiros desenvolvimentos da manufatura; quando havia uma aguda escassez de mão de obra, e, portanto, uma maior valorização da vida humana. Nesse contexto histórico, as penas capitais e os castigos corporais entram em declínio, e os criminosos passam a ser punidos através de procedimentos mais produtivos, com trabalhos forçados nas metrópoles, nas galeras e nas colônias. $\mathrm{O}$ terceiro período é o do sistema produtivo capitalista industrial, no qual - ainda que as oscilações entre oferta e demanda de mão de obra sejam extremamente rápidas e dinâmicas - em linhas gerais, é possível verificar um excedente de mão de obra, e uma conseqüente desvalorização da vida humana. Desse modo, a punição se faz menos produtiva, e a prisão passa a ser a pena por excelência, funcionando segundo uma 
dinâmica que estabelece que as condições de vida internas aos presídios devem sempre ser piores do que as piores condições de vida existentes do lado de fora das instituições penais.

Rusche e Kirchheimer realizam uma extensa reflexão sobre os motivos pelos quais a desvalorização da vida humana no período moderno não implicou um retorno substantivo às penas corporais e capitais. Para explicar esse aparente enigma, que contradiria os fundamentos do argumento, os autores analisam detalhadamente o desenvolvimento das casas de correção, as funções econômicas e sociais do trabalho penal, os percalços do processo de industrialização em diferentes países, os avanços políticos e ideológicos da burguesia, atentando, principalmente, para as repercussões teóricas e práticas de todo um novo pensamento penalista que emergiu no período do Iluminismo. É através desse minucioso trabalho analítico que os autores formulam a hipótese da prisão dissuasiva, e identificam o princípio de less eligibility (de piores condições de vida dentro da prisão do que as piores condições de vida fora) como organizador da pena de prisão no sistema produtivo capitalista.

A esse princípio fundamental se submetem os programas de reforma das prisões, desenvolvidos em diferentes países ocidentais nos últimos séculos. Esses programas que apregoam um tratamento mais racional e humanizado do criminoso - e que através da prisão visam regenerar e reinserir o criminoso na sociedade - nunca podem se realizar plenamente, uma vez que seus avanços e recuos dependem mais das condições exteriores do mercado de trabalho do que da capacidade administrativa dos gestores penitenciários. Por isso, contraditoriamente, o discurso ideológico reformador é quase sempre acompanhado de uma realidade de superpopulação carcerária, de péssimas condições de higiene e saúde no interior dos presídios, de ócio generalizado (ou de trabalhos meramente punitivos, sem funções econômicas relevantes), de altos índices de mortalidade no interior dos presídios, etc.; atributos que evocam os tradicionais castigos corporais e capitais, e fazem do nível de vida no interior da instituição penal sempre mais baixo do que o nível mínimo fora da prisão.

Foucault - em "Vigiar e Punir", originalmente publicado em 1975 - vai recuperar alguns dos preceitos estabelecidos por Rusche e Kirchheimer para desenvolver suas análises, especialmente no que se refere às especificidades e positividades de uma forma de punição: 
"Do grande livro de Rusche e Kirchheimer podemos guardar algumas referências essenciais. Abandonar em primeiro lugar a ilusão de que a penalidade é antes de tudo (se não exclusivamente) uma maneira de reprimir os delitos e que nesse papel, de acordo com as formas sociais, os sistemas políticos ou as crenças, ela pode ser severa ou indulgente, voltarse para a expiação ou procurar obter uma reparação, aplicar-se em perseguir o indivíduo ou em atribuir responsabilidades coletivas. Analisar antes os "sistemas punitivos concretos", estudá-los como fenômenos sociais que não podem ser explicados unicamente pela armadura jurídica da sociedade nem por suas opções éticas fundamentais; recolocá-los em seu campo de funcionamento onde a sanção dos crimes não é o único elemento; mostrar que as medidas punitivas não são simplesmente mecanismos "negativos" que permitem reprimir, impedir, excluir, suprimir; mas que elas estão ligadas a toda uma série de efeitos positivos e úteis que elas têm por encargo sustentar (e nesse sentido, se os castigos legais são feitos para sancionar as infrações, pode-se dizer que a definição das infrações e sua repressão são feitas em compensação para manter os mecanismos punitivos e suas funções).” (FOUCAULT, 1996, pp.24-25 - grifo meu)

Porém, no que diz respeito a essas funções, Foucault se afasta da teoria materialista histórica de Rusche e Kirchheimer - para os quais a função primordial de qualquer sistema punitivo seria operar uma certa regulação de oferta e demanda de mão de obra. Para Foucault, diferentes sistemas punitivos expressam diferentes racionalidades, diferentes relações de poder, respondem a problemas estratégicos distintos, constituem arranjos específicos de poder-saber, que são desprovidos de uma função essencial que os unifique e totalize. Enquanto Rusche e Kirchheimer privilegiam as determinações econômicas de um sistema punitivo, Foucault se debruça sobre a especificidade das relações de poder e saber que o conformam.

"Vigiar e Punir" começa pela contraposição de descrições de um brutal ritual de suplício e de um sóbrio regulamento de uma casa de detenção para jovens. No contraste gritante entre as duas formas punitivas, o autor situa o seu problema de investigação. Compreender a passagem de uma forma punitiva a outra é sim considerar as transformações econômicas, mas também é considerar a mudança de racionalidade, de 
objeto, de práticas e das formas pelas quais o poder se exerce. Foucault sustenta que o suplício era um ritual político de produção, demonstração, afirmação do poder soberano, do poder do rei sobre a vida e a morte de seus súditos. Já a prisão e seu minucioso regulamento são expressões de um poder disciplinar, de uma racionalidade que interpela as disposições para o crime, mais do que o crime em si, de um poder que não se exerce num episódio público e ostensivo sobre um corpo em evidência, mas sim discretamente, continuamente, indefinidamente, e sobre a quantidade de corpos que se considere necessária e possível.

Na passagem do suplício à prisão, o que pode aparecer como suavização, humanização, racionalização da pena, deve ser visto, segundo Foucault, como intensificação, extensão e maior produtividade da punição. Prender ao invés de esquartejar não é punir menos ou mais humanamente, é punir mais com menos recursos, é punir mais eficazmente, é punir economicamente. Para explicar essa eficácia econômica da prisão Foucault recorre a deslocamentos que se davam no plano dos ilegalismos populares. Segundo o autor, no Antigo Regime - período de preeminência do poder soberano -, existia uma ampla tolerância entre os ilegalismos das elites e das classes populares. Os delitos que acionavam os mecanismos punitivos do suplício eram aqueles que atentavam direta ou simbolicamente contra o corpo do rei, contra o poder soberano. Mas, com o avanço da industrialização, a conseqüente proliferação das mercadorias em circulação e em estoque, a ascensão dos estratos burgueses às esferas de poder, e o aumento pronunciado das populações urbanas, os ilegalismos populares tendem aos crimes contra a propriedade, despertando maior atenção das novas classes dominantes. Desse modo, fez-se necessário um tipo de sistema punitivo que deixasse menos lacunas às práticas ilegais, que fosse mais eficiente, mais extensivo e menos custoso - em termos econômicos e políticos. A pena de prisão, defendida pelos reformadores do sistema penal e propagada com mais humana frente aos suplícios, também atendia subrepticiamente essas demandas de regularidade e eficiência econômica da punição.

Poder-se-ia objetar que a prisão foi sempre ineficaz nessa pretensa tarefa de se opor e prevenir a proliferação dos ilegalismos populares contra os interesses e os direitos de propriedade das novas elites, na medida em que ao invés de reprimir a delinqüência, a prisão a produzia, a profissionalizava. Ao incluir essa possível crítica no próprio 
mecanismo de implantação da punição em forma de prisão, Foucault sofistica seu argumento, indicando outros sentidos para a produtividade e a eficácia da prisão.

Foucault mostra como a implantação da prisão, a crítica de sua ineficácia e o desenvolvimento de programas para sua reforma são processos sincrônicos e articulados. A formulação das mesmas críticas $^{10}$ e dos mesmos princípios reformadores $^{11}$ são peças que compõem e fundamentam a implantação e extensão da pena de prisão, porque a eficácia da prisão não seria exatamente a de reprimir ou prevenir os ilegalismos populares, mas sim de geri-los diferencialmente. Ou seja, a prisão não fracassa absolutamente ao produzir uma delinqüência organizada e profissionalizada, uma vez que essa mesma delinqüência pode ser utilizada, penetrada e mobilizada para operar outros ilegalismos, isolar uns, evidenciar outros. Nas palavras do autor:

"Mas talvez devamos inverter o problema e nos perguntar para que serve o fracasso da prisão; qual é a utilidade desses diversos fenômenos que a crítica, continuamente, denuncia: manutenção da delinqüência, indução em reincidência, transformação do infrator ocasional em delinqüência. Talvez. devamos procurar o que se esconde sob o aparente cinismo da instituição penal que, depois de ter feito os condenados pagar sua pena, continua a segui-los através de toda uma série de marcações (...) e que persegue assim como 'delinqüente' aquele que quitou sua punição como infrator? Não podemos ver aí mais que uma contradição, uma conseqüência? Deveríamos então supor que a prisão e de uma maneira geral, sem dúvida, os castigos, não se destinam a suprimir as infrações; mas antes a distingui-las, a distribuí-las, a utilizá-las; que visam, não tanto tornar dóceis os que estão prontos a transgredir as leis, mas que tendem a organizar a transgressão das leis numa tática geral das sujeições. A penalidade seria então uma maneira de gerir as ilegalidades, de riscar limites de tolerância, de dar terreno a alguns, de fazer pressão sobre outros, de excluir uma parte, de

\footnotetext{
${ }^{10}$ A prisão não reduz a criminalidade, provoca a reincidência, fabrica delinqüentes, permite a sua organização coletiva, etc.

${ }^{11}$ O objetivo da prisão é transformar os indivíduos, os presos devem ser separados segundo suas especificidades, a duração da pena deve variar segundo os progressos do indivíduo, o preso deve trabalhar e se educar, os profissionais da prisão devem ser especializados, e o egresso da prisão deve ser assistido para não reincidir.
} 
tornar útil outra, de neutralizar estes, de tirar proveito daqueles. Em resumo, a penalidade não 'reprimiria' pura e simplesmente as ilegalidades; ela as 'diferenciaria', faria sua 'economia' geral. E se podemos falar de uma justiça não é só porque a própria lei ou a maneira de aplicá-la servem aos interesses de uma classe, é porque toda a gestão diferencial das ilegalidades por intermédio da penalidade faz parte desses mecanismos de dominação. Os castigos legais devem ser recolocados numa estratégia global das ilegalidades. O 'fracasso' da prisão pode sem dúvida ser apreendido a partir daí.” (FOUCAULT, 1996, pp.226-227 - grifo meu)

Portanto, a conformação da delinqüência, a estruturação de um meio delinqüente dentro da prisão e que se estende para fora dela são elementos que permitem interpelar o encarceramento em sua positividade, em sua produtividade estratégica. Tal hipótese produtiva é coextensiva ao domínio do ambiente familiar do preso, uma vez que a crítica à produção da delinqüência é também formulada nesses termos, como Foucault indica ao enumerar as críticas que sempre se faz para denunciar o fracasso da prisão:

"Enfim a prisão fabrica indiretamente delinqüentes, ao fazer cair na miséria a família do detento: 'A mesma ordem que manda para a prisão o chefe de família reduz cada dia a mãe à penúria, os filhos ao abandono, a família inteira à vagabundagem e à mendicância. Sob esse ponto de vista o crime ameaça prolongar-se." (FOUCAULT, 1996, p.223 - citando CHARLES LUCAS, De la réforme des prisons, 1838, p. 64.)

Foucault situa a prisão numa estratégia geral de controle social, através da gestão diferencial dos ilegalismos - que por sua vez se dá via a produção de uma delinqüência domesticada, manipulável, operacionalizável, seja para viabilizar lucrativos mercados ilícitos (como a prostituição no século XIX), seja para policiar e minar associativismos populares (pela infiltração de informantes e agitadores), seja para eclipsar, pelo escândalo que provocam, outros ilegalismos que são e devem ser tolerados. Assim temse uma outra matriz analítica para se pensar a prisão e seus efeitos sobre indivíduos, famílias e comunidades, que não se limita à denúncia da desestruturação que a prisão impõe, mas que parte dessa desestruturação, que a reinsere num campo político estratégico, que precisa ser mais bem entendido e problematizado. É nesse horizonte de questões que se pretendeu pautar o presente trabalho. De todo modo, entre a 
implantação da prisão nos séculos XVIII e XIX e sua atualidade muita coisa mudou, de forma que algumas mediações se fazem necessárias.

\section{4 - Mediações}

As inversões e cuidados analíticos que possibilitaram a formulação do que aqui chamei de hipótese produtiva devem ser retidas como grade geral de interpretação, como uma perspectiva do olhar. Uma perspectiva que agora se volta para uma prisão já bastante transformada, uma prisão que desde o último terço do século $\mathrm{XX}$ vem aceleradamente distanciando-se daquele "modelo" de prisão disciplinar.

Uma primeira demarcação de distância entre o que Foucault analisou e o que aqui se pretende analisar é que atualmente não se entende que a prisão continuamente fracassa em seus objetivos declarados. Novos objetivos se estabeleceram, de modo que se faz possível afirmar o anteriormente impensável: a prisão funciona! Sobre essa significativa guinada no pensar e no exercer o poder de punir, que Garland $(1999,2001,2005)$ focou boa parte de seu trabalho nos últimos anos. De acordo com esse autor, até a década de 1970, os sistemas punitivos ocidentais funcionavam sob uma configuração que ele chama de "penal-walfare" (GARLAND, 2005, p.71). Pode-se conceber essa configuração em relativa continuidade com a prisão disciplinar analisada por Foucault, obviamente, acrescida de um conjunto de sofisticações. Tais aprimoramentos decorriam também do jogo entre a constante crítica da ineficácia e a reafirmação de um programa regenerador, na medida em que o objetivo declarado do complexo penal-welfare era ainda reabilitar o delinqüente para o convívio social. A partir dos anos 1970, a impossibilidade de se atingir esse objetivo deixa de impor sofisticações ao programa punitivo; o próprio objetivo é reformado, passando a ser concebido como a incapacitação, a anulação, a exclusão, a eliminação de indivíduos delinqüentes em nome da segurança da sociedade. Nas palavras do autor:

"Em claro contraste com o que era a visão convencional no período anterior, o pressuposto dominante atualmente é que a 'prisão funciona', 
não mais como um mecanismo de reforma ou reabilitação, mas sim como meio de incapacitação e castigo que satisfaz a demanda política popular de retribuição e segurança pública. Os últimos anos testemunharam uma destacada reviravolta na sorte da prisão. Uma instituição com uma longa história de expectativas utópicas e tentativas periódicas de reinventar-se (...) finalmente viu sua ambição reduzida drasticamente à incapacitação $\boldsymbol{e}$ ao castigo retributivo. (...) No curso de poucas décadas deixou de ser uma instituição correcional desacreditada e decadente, para se constituir em um pilar maciço e aparentemente indispensável da ordem social contemporânea." (GARLAND, 2005, p.51 - tradução e grifos meus)

O declínio do ideal de reabilitação é a marca atual da pena de prisão, e segundo o autor, ele se insere num conjunto mais amplo de reconfigurações, tanto nas formas de se conceber e se exercer a punição, quanto nas formas de se conceber o próprio Estado, seus limites e atribuições. Nestes termos, a crise do papel social da prisão se relaciona com a crise do Estado de Bem-Estar e da própria sociedade industrial. Impossível recuperar aqui todo o percurso analítico de Garland, que vai desde o jogo de relações entre grupos de poder e operadores do sistema penal-welfare nos Estados Unidos da década de 1970, até as macro-transformações sociais, culturais, políticas e econômicas que se dão no mundo ocidental no período pós-guerra. Trata-se de um processo por demais complexo para ser deslindado no escopo desse trabalho. O que é possível apresentar esquematicamente é um conjunto de alterações que, articuladas ao declínio do ideal de reabilitação, reconfiguram o que o autor chama de campo do controle do delito e justiça penal.

De acordo com Garland (2005), com o declínio do ideal de reabilitação, as sanções punitivas readquirem o caráter expressivo, retributivo e vingativo que predominava nos tempos dos suplícios. Se anteriormente as políticas penais eram pautadas por certa confiança na razão e no progresso, agora são pautadas por uma sensação difusa de medo, de urgência e de ameaça. A figura da vítima passa a ocupar uma posição central no interior do campo; ela é reiteradamente evocada para justificar a necessidade de punições mais duras, exemplares, expressivas; na sua exposição se apóia uma sensação de insegurança generalizada, e no destaque dado à sua dor se apóia um desejo coletivo de vingança. A figura simbolizada da vítima adere a toda a sociedade, todos os homens 
“de bem” são vítimas potenciais, e é toda essa massa vulnerável que deve ser protegida por uma ação pró-ativa e incessante das "forças de segurança". A segurança emerge como questão central na vida política, econômica e social ${ }^{12}$, e todos os esforços que se fazem no sentido de promovê-la são, ao mesmo tempo, bem vistos e sempre insuficientes. Enquanto a segurança se torna uma obsessão política, todo um conjunto de práticas e saberes que a abordam de um modo mais indireto e processual - o estudo das causas profundas do crime, a intervenção diversificada e progressiva sobre um criminoso - passam a ser vistos como irracionalidades, indulgências, que não só desperdiçam recursos valiosos, como fomentam e promovem a ameaça.

Os agentes que mobilizam e colocam em jogo esses elementos para pensar e desenvolver novas políticas de controle do delito e justiça penal já não são, apenas, os criminólogos, sociólogos, psicólogos e especialistas em geral, que atuavam no aparato penal-welfarista. Os políticos dos mais diferentes matizes ideológicos, baseados num grande consenso - naquilo que julgam todos saberem e compartilharem sobre o delito e a justiça -, passam a ser cada vez mais determinantes na conformação de políticas e programas penais. O discurso técnico e especializado é deslocado para segundo plano, de modo que as políticas criminais e penais passam a ser formuladas num tipo de discurso popular, populista, como respostas simples e reações diretas, proporcionais, calcadas no real, no imediato, no evidente. São eles proclamadores fundamentais de afirmações como: A prisão funciona! Ela incapacita o criminoso perigoso! Ela vinga a vítima inocente! Ela protege a sociedade!

Uma vez deslocados, os saberes técnicos não ficam inertes. Eles são mobilizados para dar sustentação às novas políticas, e nesse movimento são reformulados, assumindo para si outros problemas e desafios. Enquanto eram orientados pelo ideal reabilitador, os saberes especializados se voltavam para a compreensão de macro-processos sociais de produção do delito, para as carências coletivas e privações relativas que afetam um indivíduo e o conduzem ao crime. ${ }^{13}$ A partir da década de 1970 , emerge um novo tipo de saber especializado que toma o infrator como um agente racional que aproveita oportunidades delitivas que se apresentam no ambiente, de modo que as causas do crime já não são atribuídas a macro-processos sociais, mas a insuficiências nos

\footnotetext{
${ }^{12}$ Para uma discussão sobre a crescente centralidade das questões de segurança, ver: FOUCAULT (2006) e CASTEL (2003).

${ }^{13}$ Para uma discussão sobre as relações entre privação e delinqüência, ver: SÁ (2000).
} 
investimentos em controles situacionais, ambientais ou comportamentais. A produção social da delinqüência e do delito deixam de ser objetos de problematização e compreensão, tornam-se dados da realidade, processos quase naturais, frente aos quais se deve atuar, na melhor das hipóteses, minimizando oportunidades, custos e danos; seja intervindo no espaço - aumentando controles situacionais indiretos, com câmeras de vigilância, iluminação, muros, grades, etc. - seja influenciando e conduzindo os comportamentos (de risco) de vítimas potenciais.

O criminoso não é mais pensado como o sujeito carente, mas sim como um homem comum, que autônoma e racionalmente opta pela vida do crime, e que o fazendo deve assumir e se responsabilizar pelos riscos que seus investimentos implicam, entre eles o de ser preso. Modulações compreensivas de sociologia e psicologia cedem lugar a uma abordagem economicista do comportamento criminoso e das práticas punitivas - Becker (1968) foi um dos pioneiros em formular o delito e a prisão como variáveis econômicas, oscilantes em função de investimentos positivos e negativos. Foucault (2008) também abordou essa passagem cognitiva, quando a economia passa a ser a grade de inteligibilidade dos fenômenos criminais e punitivos. Segundo ele, esse é um dos marcos que estabelecem uma nova arte de governar as populações, um novo regime de poder-saber heterogêneo ao arranjo disciplinar.

Desenvolve-se uma percepção generalizada de que os riscos do crime se proliferam no ambiente, e toda uma infra-estrutura de prevenção do delito, de segurança pessoal e comunitária se expande. A ação policial deixa de ser vista simplesmente como o "combate ao crime", passando a ser vista como um serviço de distribuição de segurança. A auto-suficiência e exclusividade da ação policial contra o crime são colocadas em questão, passando a ser incentivado todo um arranjo sinergético de diferentes atores locais e comunitários, que por outros instrumentos, e em colaboração com a polícia, passam a ser vistos como estratégicos para a "segurança comunitária". ${ }^{14}$ A sociedade civil e a iniciativa privada são chamadas à tarefa de colaborar com o controle do delito, de modo que as fronteiras institucionais do "Estado" se diluem, e seu monopólio sobre o controle da violência é substituído por uma economia mista de produção da segurança.

\footnotetext{
${ }^{14}$ Para uma discussão acerca dos recentes deslocamentos nas práticas policiais, ver: O’MALLEY, P; HUTCHINSON, S. (2007). Sobre o crescente envolvimento da comunidade local nas políticas de segurança, ver: ROSE (1996).
} 
Nesse novo "mercado aberto" da segurança, forças policiais e empresas de segurança privada, instituições estatais e organizações da sociedade civil compartilham uma mesma racionalidade empresarial de prestação de serviços, focalizando recursos, estabelecendo metas, e apoiando-se em indicadores de desempenho. Nesse sentido, a justiça penal, que anteriormente funcionava sob a lógica da regulação moral, passa a ser administrada segundo os princípios da boa gestão econômica.

Para finalizar esse sumário de grandes alterações, Garland ressalta a permanente sensação de crise que prevalece no interior do campo do controle do delito e justiça penal. Todo momento é de alta comoção popular, crimes devastadores espreitam ininterruptamente, nunca é tempo de relaxar, sempre reformas urgentes são necessárias, sempre há algo a mais para se fazer, e nunca as ferramentas mais adequadas são conhecidas e estão disponíveis, de modo que sempre é preciso mobilizar todos os recursos que se tenha à mão.

A resultante desse amplo conjunto de vetores é um cada vez mais intenso uso do encarceramento, acompanhado de uma ampliação da duração das penas; fatores que elevam a população penitenciária a níveis até então desconhecidos. $\mathrm{O}$ encarceramento em massa, a ampliação dos parques penitenciários, o incremento nas taxas de encarceramento são alguns dos efeitos imediatos dessa nova convicção de que a prisão funciona.

Segundo Garland (2001), essa nova cultura punitiva - cultura do controle - impõe toda uma agenda para a investigação sociológica, sendo a questão dos impactos desse encarceramento massivo em famílias e comunidades uma das pautas mais prementes:

"As Mauer and Huling (1995) and others have shown, 1 in 3 black men aged 20 to 29 years of age is currently in penal custody or under penal supervision. If current trends continue, 30 percent of all black males born today will spend some of their lives in prison. (The comparative figure for white males is 4 percent and for Hispanics 14 percent) This means that imprisonment has become one of the social institutions that structure this group's experience. It becomes part of the socialization process. Every family, every household, every individual in these neighborhoods has direct personal knowledge of the prison - through a spouse, a child, a 
parent, a neighbor, a friend. Imprisonment ceases to be the fate of a few criminal individuals and becomes a shaping institution for whole sectors of the population.

We do not currently know what 'mass imprisonment' will mean for the society in which it develops, or for the groups who are most affected. As Frank Zimring and Gordon Hawkins (1991) have pointed out, we do not have a jurisprudence of imprisonment. For all of our philosophizing about the purpose of imprisonment, we have scarcely begun to address the question of its extent. We have libraries of criminological research about the impact of imprisonment upon the individual offender, but scarcely anything on its social impact upon communities and neighborhoods." (GARLAND, 2001, p.2 - grifos meus)

Portanto, questões de como a prisão se converte em instituição socializadora para amplos setores da população, de como ela socializa agentes para além de seus limites institucionais, pelo salto de escala, recobram importância no mundo contemporâneo. $\mathrm{O}$ quê o encarceramento em massa vem produzindo nas sociedades em que se desenvolve? Eis uma pergunta que está na ordem do dia.

Agora - e retomando a hipótese produtiva foucaultiana - se para o século XIX, o segredo da produtividade da prisão estava na eficácia inversa que aparecia como acusação de fracasso, na própria produção da delinqüência; no fỉnal do século XX e começo do XXI, inversamente, talvez o segredo do que a prisão massificada vem produzindo esteja no fracasso escondido sob a proclamação reiterada de que a prisão funciona. De um lado, ambientes familiares e comunitários que se estruturam em função de uma prisão proclamada incapacitante e segregadora; de outro, a produção de uma delinqüência organizada que muito pouco se assemelha àquela delinqüência domesticada, penetrável, manipulável do século XIX, são elementos que podem ser considerados indícios de importantes deslocamentos na produtividade prisional. Explorar deslocamentos como esses é a tarefa que se assumiu nesse trabalho. 


\section{2 - Massificação do encarceramento}

Nesse segundo capítulo pretende-se realizar uma primeira aproximação aos dois contextos sociais que foram contemplados na pesquisa, explorando diferentes aspectos do desenvolvimento recente do encarceramento na Catalunha e em São Paulo. Porém, antes de passar aos dados, é importante demarcar as linhas gerais que vêm caracterizando o debate sobre o encarceramento e seu processo de massificação no mundo ocidental contemporâneo, e que pautaram a busca de informações secundárias em cada um dos contextos estudados.

\section{1 - Pauta}

Um mapa inicial das principais questões e autores que incidem no debate acerca das mudanças recentes no dispositivo prisional que resultaram no aumento pronunciado da população carcerária pode ser encontrado no livro "Mass imprisonment: social causes and consenquences", organizado por Garland (2001). No texto introdutório à coletânea, como ponto de partida de todo o debate, Garland destaca o aumento pronunciado da taxa de encarceramento nos Estados Unidos durante o último quarto do século $\mathrm{XX}$, quando saltou de 110/100 mil habitantes, em 1973, para 680/100 mil, no final da década de 1990. Esse aumento acelerado e sem precedentes levou o governo dos Estados Unidos a contabilizar e gerir uma população prisional de mais de dois milhões de pessoas - majoritariamente negras e latinas - no começo do século XXI. Segundo Garland, esse é um fenômeno extraordinário, dificilmente comparável ao encarceramento de qualquer outro país ocidental contemporâneo. Tamanha excepcionalidade exigiria um nome próprio: “mass imprisonment” (GARLAND, 2001, p.1).

Garland sugere que o encarceramento em massa estaria para os Estados Unidos contemporâneo como o "Arquipélago Gulag", descrito por Alexandr Solzhenitsyn 
(1974), está para a União Soviética; e como a "Grande Internação", descrita por Foucault em "História da Loucura na Idade Clássica" (1978), estaria para a Europa do século XVII. Singularidades históricas, portanto.

A excepcionalidade e a singularidade dos níveis de encarceramento nos Estados Unidos da passagem do século pauta toda a reflexão sobre o aumento do encarceramento. Tonry (1999) - em artigo intitulado "Why are U.S. incarceration rates so high?" - estabelece alguns parâmetros para demarcar a excepcionalidade da punição contemporânea nos Estados Unidos: taxa de encarceramento de seis a doze vezes maior que a de outros países ocidentais; progressiva redução dos direitos dos presos; manutenção e aumento da utilização das penas de morte, perpétua e outras sem possibilidade de "parole" adoção de listas de sentenças pré-estabelecidas ${ }^{16}$; aumento da duração das penas; políticas de "tolerância zero"17 e de "three strikes and you're out" 18 . Segundo o autor, a confluência desses elementos conforma, nos Estados Unidos, um paradigma punitivo único.

Kuhn (2001), comparando tendências nas taxas de encarceramento de diferentes países, chega a conclusão parecida. Em "Incarceration rates across the world", afirma: "the United States is unique in its steep and continuous increase in incarceration rates since 1973." (KUHN, 2001, p.114 - grifo meu) Também para Kuhn, a singularidade do encarceramento em massa nos Estados Unidos se relaciona com as singulares políticas que vêm sendo adotadas no campo da justiça criminal no decorrer dos últimos anos.

Mauer (2001), em "The causes and consequences of prison growth in the United States" aprofunda a análise dessas políticas e as contextualiza num movimento político mais geral, que se orienta por um discurso de endurecimento contra o crime. Segundo esse autor, três fatores convergem na conformação das políticas criminais de endurecimento penal que promovem o encarceramento em massa nos Estados Unidos. Em primeiro lugar, a politização do crime. Mauer afirma que antes da década de 1960, os problemas relacionados à criminalidade não figuravam na agenda política nacional; mas, em 1964, pela primeira vez, o candidato republicano à presidência, Barry Goldwater, destacou na

\footnotetext{
${ }^{15}$ Cumprimento de parte da pena em liberdade.

${ }^{16}$ Estabelecimento de penas determinadas para determinados delitos, sem deixar margem à interpretação e avaliação do juiz.

${ }^{17}$ Endurecimento das penas para delitos menos graves.

${ }^{18}$ Endurecimento das penas para reincidentes.
} 
sua plataforma política o problema do "crime nas ruas". Em 1968, Richard Nixon seguiu a mesma linha, clamando por "lei e ordem" contra o crime. A partir de então, o enfrentamento do crime se impôs na agenda política nacional, tanto de republicanos quanto de democratas. Em segundo lugar, Mauer destaca a cultura individualista norteamericana, que cria um ambiente receptivo para políticas de endurecimento penal, na medida em que estas visam os comportamentos individuais desviantes, mais do que os fatores sociais que impulsionam a criminalidade. Em terceiro lugar, o autor destaca um crescente clima político conservador, particularmente evidente a partir da eleição presidencial do republicano Ronald Reagan, em 1980, que propunha a extensão das políticas de endurecimento contra o crime, contra a imigração, contra beneficiários de programas de bem-estar social, e contra outros grupos marginalizados. Nestes termos, a particularidade das taxas de encarceramento nos Estados Unidos se relacionaria a processos políticos e culturais também particulares.

Por sua vez, para Downes (2001) - em "The macho penal economy: mass incarceration in the United States - a European perspective" - a excepcionalidade do encarceramento em massa nos Estados Unidos deve ser colocada em perspectiva com a excepcionalidade do próprio sistema penal nesse país como um todo. $\mathrm{O}$ autor lembra que tão excepcional quanto o encarceramento em massa contemporâneo é a constituição da democracia liberal norte-americana de forma articulada, desde o princípio, com a conformação de um robusto sistema penitenciário. Mais adiante, Downes relativiza essa excepcionalidade do encarceramento em massa nos Estados Unidos, afirmando que tal singularidade só se sustenta se tomamos como plano de referência o tempo presente. Segundo o autor, é necessário avaliar se a "receita" do encarceramento em massa estadunidense já está presente, ainda que sob uma forma embrionária, em outros países. Expondo e analisando políticas criminais no Reino Unido, Downes conclui que a excepcionalidade do encarceramento em massa nos Estados Unidos não se sustenta por muito tempo.

Wacquant (2007) vai na mesma direção, por outros meios. Em “'Enemigos convenientes ': extranjeros e inmigrantes en las cárceles de Europa”, esse autor sustenta que existem analogias substantivas entre o encarceramento contemporâneo nos Estados Unidos e nos países da Europa Ocidental. Ao definir as causas fundamentais do encarceramento em massa, parece-lhe difícil sustentar a excepcionalidade do caso 
estadunidense. Segundo Wacquant, o encarceramento em massa é produto: 1 - de uma dualização do mercado de trabalho, com a generalização do trabalho precário, do desemprego e do subemprego; 2 - do desmantelamento dos programas de assistência pública característicos do Estado de Bem-Estar Social; e 3 - da crise do gueto como instrumento de controle e confinamento de grupos populacionais estigmatizados. Para Wacquant, tais processos estão em andamento tanto nos Estados Unidos quanto nos países da Europa Ocidental, de modo que o papel de "cliente" preferencial do sistema punitivo, desempenhado pelos negros nos Estados Unidos, é desempenhado pelos estrangeiros e "quase-estrangeiros" $" 19$ na Europa.

Como é possível observar, o encarceramento em massa pode ser abordado ou como um processo singular e excepcional que tem lugar atualmente nos Estados Unidos, ou como uma tendência geral identificável em diferentes países ocidentais. De todo modo, não me parece que ambas as perspectivas sejam mutuamente excludentes. O próprio Garland (1999), que afirma a singularidade histórica do encarceramento em massa nos Estados Unidos, identifica - em "As contradições da 'sociedade punitiva': o caso britânico" - uma tendência ao encarceramento em massa no Reino Unido:

“Em sociedades como as do Reino Unido e dos Estados Unidos, onde há divisões sociais e raciais profundas, onde as taxas de criminalidade e os níveis de insegurança são elevados, onde as soluções sociais foram politicamente desacreditadas, onde há poucas perspectivas de reintegração dos antigos delinqüentes pelo trabalho ou pela família e onde, para finalizar esse quadro deprimente, um setor comercial em expansão encoraja e favorece o aumento do encarceramento, essa cultura punitiva está provocando um encarceramento em massa em uma escala inédita em países democráticos, e raramente encontrada na maior parte dos países totalitários." (GARLAND, 1999, p.71 - grifo meu).

Christie (1993) - em "Crime control as industry: towards Gulags, western style" articula explicitamente a análise do encarceramento em massa como caso e como tendência. Segundo o autor, os Estados Unidos podem ser considerados o "trend-setter" dos sistemas punitivos contemporâneos, isto é, ao mesmo tempo, caso singular e

\footnotetext{
${ }^{19}$ Imigrantes de segunda geração, percebidos como estrangeiros sem necessariamente sê-lo.
} 
modelo que indica a tendência. Christie identifica a tendência de aumento substancial da taxa de encarceramento mesmo em países europeus que encarceram relativamente pouco, como Holanda e Noruega. Já para os Estados Unidos, o autor desagrega os dados do encarceramento por estado, demonstrando a variedade de situações punitivas que compõem o caso estadunidense, de modo que permite observar a existência de estados dentro dos Estados Unidos em que o encarceramento em massa já era uma realidade no começo da década de 1990, e outros em que era ainda uma tendência.

É possível diferenciar, portanto, abordagens do encarceramento em massa nos Estados Unidos, que ressaltam a sua excepcionalidade e atentam para os processos particulares que o conformam; de abordagens do encarceramento em massa como tendência geral identificável em diferentes países ocidentais. Para diferenciar as abordagens e o campo de questões que levantam, parece-me adequado especificar o caso estadunidense como de encarceramento em massa, e a tendência identificável em diferentes países como processo de massificação do encarceramento.

Nas análises do processo de massificação do encarceramento, procedimentos comparativos são recorrentemente mobilizados. Uma constante nessas análises é que elas se restringem à comparação de taxas de encarceramento e políticas criminais principalmente aos efeitos de políticas de "guerra contra o crime" e "guerra contra as drogas" - entre diversos países desenvolvidos e o caso estadunidense. Wacquant (2007) fala da Inglaterra, Espanha, França e Holanda. Garland (1999), do Reino Unido; Christie (1993), da Holanda, Noruega, Finlândia. Os chamados países "em vias de desenvolvimento" - por mais que apresentem taxas de encarceramento crescentes, divisões sociais e raciais profundas, elevados níveis de criminalidade e insegurança, e um robusto aparato privado de controle do delito - não são levados em conta no debate científico internacional, não obstante, no Brasil e em outros países subdesenvolvidos ${ }^{20}$ essa mesma tendência seja identificável.

De todo modo, esse breve mapeamento do debate acrescido às mediações anteriormente apresentadas - as do reconfigurado campo do controle do delito e justiça penal discutidas por Garland - já são suficientes para melhor qualificar uma aproximação do encarceramento contemporâneo no Brasil e na Espanha, atentando para o aumento das

\footnotetext{
${ }^{20}$ Para o caso mexicano, ver: BERGMAN; AZAOLA (2007); para o caso argentino, ver: PEGORARO (2000); e para o caso chileno, ver PINCHEIRA (2008).
} 
taxas de encarceramento, sua distribuição diferencial no território, a concentração de sua incidência em determinados grupos populacionais, as políticas criminais que o promovem e a cultura política que o sustenta.

\section{2 - São Paulo, Brasil}

Segundo Adorno e Salla (2007), em 1969, no Brasil havia 28.538 presos, representando uma taxa de encarceramento de 30/100 mil habitantes. Em 1988, a população carcerária já era de 88.041 presos, e a taxa de encarceramento saltava para 65,2/100 mil. Em 19 anos a taxa de encarceramento brasileira aumentou 117,3\%. Em 1997, a população carcerária era de 170.207 presos, e a taxa de encarceramento era de 108,6/100 mil. Em nove anos, um crescimento de 66,5\% na taxa. Em 2006, a população carcerária era de 401.236 presos, e a taxa de encarceramento era de 214,8/100 mil. Mais nove anos e a taxa de encarceramento aumentou mais $97,7 \%$. Segundo informações do Departamento Penitenciário Nacional (DEPEN, 2010), em junho de 2009, a população carcerária brasileira já era de 469.546 presos e a taxa de encarceramento já alcançava a cifra de 247,7/100 mil habitantes. Portanto, é possível afirmar que, entre 1969 e junho de 2009, a população carcerária brasileira cresceu $1.545,3 \%$, e a taxa de encarceramento aumentou $725,6 \%$.

Se se segue o exemplo de Christie e se decompõe esses dados para as diferentes unidades da federação, é possível perceber que o incremento nas taxas de encarceramento se distribui diferencialmente pelo território nacional. Salla (2007) apresenta mais detalhadamente o caso paulista. Segundo esse autor, em 1976, o estado de São Paulo contabilizava 17.192 presos, e uma taxa de encarceramento de 79,3/100 mil habitantes. Em 1986, a população carcerária paulista era de 24.091 presos, e a taxa de encarceramento era de 85,1/100 mil. Em 1996, a população carcerária saltava para 66.278 presos, e a taxa de encarceramento, para 194,5/100 mil. ${ }^{21}$ De 1976 a 1986, a taxa de encarceramento subiu apenas 7,3\%; mas, entre 1986 e 1996, essa taxa cresceu em

\footnotetext{
${ }^{21}$ Taxa de encarceramento para o ano de 1996 calculada com base nos dados populacionais estaduais encontrados em IBGE (2010).
} 
128,5\%. Segundo o DEPEN, em junho de 2009, a população carcerária paulista é de 158.704, e a taxa de encarceramento é de 386,9/100 mil. Entre 1996 e junho de 2009, a taxa de encarceramento de São Paulo aumentou mais 98,9\%. Num período de quase 33 anos, entre 1976 e junho de 2009, a população carcerária paulista aumentou 823,1\%; e a taxa de encarceramento cresceu em $387,8 \%$.

Ainda segundo o DEPEN, em junho de 2009, apenas três estados apresentam taxas de encarceramento superiores a de São Paulo: Rondônia, com 433,9/100 mil; Acre, com 463,5/100 mil; e Mato Grosso do Sul, com 527,5/100 mil. Somando a população carcerária desses três estados chega-se ao número de 21.966 presos, o que representa apenas 4,6\% da população carcerária nacional. No mesmo período, excetuando esses três estados e São Paulo, sete estados apresentam taxas de encarceramento superiores à média nacional: Roraima, com 386,6/100 mil; Mato Grosso, com 374,9/100 mil; Paraná, com 343,4/100 mil; Distrito Federal, com 319,7/100 mil; Amapá, com 314,3/100 mil; Espírito Santo, com 300,5/100 mil; Rio Grande do Sul, com 263,6/100 mil. Somando a população carcerária desses sete estados chega-se ao número de 98.145 presos, o que equivale a $20,9 \%$ de toda a população carcerária brasileira. Só o estado de São Paulo, por sua vez, concentra 33,8\% da população carcerária nacional. Ainda que o aumento da taxa nacional de encarceramento seja resultante do aumento acumulado da taxa mesmo naqueles estados que, em junho de 2009, apresentam taxas inferiores a média nacional; esses elementos de distribuição da população carcerária pelos estados com as maiores taxas de encarceramento permitem identificar o estado de São Paulo como a principal "locomotiva" do processo de massificação do encarceramento no Brasil.

Outro elemento que corrobora essa tese é a dimensão do parque penitenciário estadual. Comparando São Paulo com o segundo estado brasileiro em população carcerária, a preeminência do sistema penitenciário paulista fica evidente. O estado de Minas Gerais contabiliza 46.926 presos, e apresenta uma taxa de encarceramento de 236,4/100 mil, em junho de 2009. Segundo o DEPEN, Minas Gerais dispõe de um total de 84 estabelecimentos penais, sendo 19 Penitenciárias, 60 Cadeias Públicas, 3 Hospitais de Custódia e Tratamento Psiquiátrico e 2 Casas de Albergados. Segundo a Secretaria de Administração Penitenciária (SAP, 2010) de São Paulo, existem no estado 147 unidades prisionais, sendo 1 Unidade de Segurança Máxima, 74 Penitenciárias, 36 Centros de 
Detenção Provisória, 22 Centros de Ressocialização, 7 Centros de Progressão Penitenciária, 2 Institutos Penais Agrícolas, e 6 Hospitais. $^{22}$ Sem dúvida o sistema carcerário paulista é o mais robusto, diversificado e complexo do Brasil.

Tendo explorado minimamente o aumento da população carcerária e da taxa de encarceramento no Brasil e em São Paulo, resta explorar a segunda característica que, segundo Garland (2001), define o encarceramento em massa: a concentração social dos seus efeitos em grupos específicos da população. Se, como afirma Wacquant, facilmente se identifica os negros e latinos como alvos preferenciais do sistema penitenciário estadunidense, e os estrangeiros e "quase-estrangeiros" como alvos preferenciais dos sistemas punitivos europeus; a particular estrutura de relações sociais e raciais no Brasil exige uma maior cautela na apreciação desse fator. ${ }^{23}$

Para explorar alguns elementos da concentração dos efeitos do encarceramento em São Paulo, é possível recorrer ao censo penitenciário, realizado em 2002, pela Fundação Dr. Manoel Pedro Pimentel (FUNAP, 2002), e a algumas informações fornecidas pelo DEPEN. Segundo a FUNAP, no sistema penitenciário paulista, 70\% dos presos são do estado de São Paulo, sendo, desses, 36\% da capital, 14\% da Região Metropolitana de São Paulo (RMSP) e 50\% de outros municípios do interior e do litoral. Ainda que existam estrangeiros nas prisões paulistas, o número é reduzido e não totaliza $1 \%$ da população prisional. Portanto, quanto à origem, é possível afirmar que $35 \%$ da população prisional do estado residia em algum dos 39 municípios que compõem a RMSP, e outros 35\% eram de algum dos outros 606 municípios do estado.

Ainda segundo a FUNAP, 97\% dos presos do estado de São Paulo são homens, 74\% não chegaram a completar o Ensino Fundamental, e menos de $1 \%$ completaram o Ensino Superior. A média de idade da população presa é de 30 anos, sendo que $32 \%$ dos presos têm entre 18 e 24 anos; e 44\%, entre 24 e 34 anos. Quanto à cor de pele, o

\footnotetext{
${ }^{22}$ A contabilidade da SAP não contempla as cadeias públicas que ainda são administradas pela Secretaria de Segurança Pública (SSP), não obstante, os dados apresentados perecem suficientes para sustentar o argumento.

${ }_{23}$ Para uma discussão sobre as diferenças entre as relações raciais no Brasil e nos Estados Unidos, ver: NOGUEIRA (2007).
} 
DEPEN informa que, em junho de 2008, 47,1\% dos presos eram brancos, $16,5 \%$, negros, e $35,9 \%, \operatorname{pardos}^{24}$, restando $0,4 \%$ na categoria "outros". ${ }^{25}$

Lembrando que uma porção significativa da população prisional do estado é oriunda da capital, e a partir desse brevíssimo perfil sócio-econômico, já é possível especular sobre a origem social da grande maioria dos presos do estado. Se se compara esses dados aos de alguns distritos da cidade de São Paulo observa-se que o perfil dos presos se aproxima ao dos moradores de bairros periféricos: jovens, de baixa escolaridade, e mais negros/pardos que brancos. Por exemplo, no distrito de Guaianases, no extremo da zona leste de São Paulo, 47\% da população só completou o Ensino Fundamental, e apenas 5\% chegaram a completar o Ensino Superior; enquanto num distrito central como o Jardim Paulista, apenas $11 \%$ só completaram o Ensino Fundamental, e 62\% completaram o Ensino Superior. ${ }^{26}$ A média de idade em Guaianases é de 35,8 anos; enquanto no Jardim Paulista é de 43,9. Em Guaianases, 38\% da população é branca, 14\%, negra, e 42\%, parda. No Jardim Paulista, $80 \%$ dos habitantes são brancos, 4\% negros, e $9 \%$ pardos.

Considerando que o perfil sócio-econômico de Guaianases não pode ser muito distinto do perfil presente em regiões periféricas dos outros 38 municípios da RMSP; e nem das regiões periféricas dos outros 606 municípios do estado, a partir do perfil sócioeconômico da população prisional é possível levantar a hipótese de que os clientes preferenciais do sistema punitivo paulista são em sua maioria residentes de áreas urbanas periféricas.

Portanto, a constatação de aumento pronunciado e sem precedentes da população prisional e da taxa de encarceramento, articulada a esses fortes indícios de concentração dos efeitos do encarceramento em grupos específicos da população - os homens, jovens, mais negros/pardos que brancos, de baixa escolaridade e moradores das periferias urbanas - permite a identificação de um processo de massificação do encarceramento no Brasil, e particularmente, em São Paulo.

\footnotetext{
${ }^{24}$ A manutenção dessa categoria obtusa de "pardo" nas pesquisas demográficas brasileiras é o principal elemento que impossibilita que se afirme categoricamente que no Brasil, como nos Estados Unidos, os negros são os principais alvos do sistema punitivo.

${ }^{25}$ O censo penitenciário da FUNAP apresenta o duvidoso índice de $22 \%$ na categoria "outros".

${ }^{26}$ Os dados sócio-econômicos por distrito estão em DATAFOLHA (2009).
} 
Para uma análise da particular evolução nas políticas criminais e penitenciárias, que ditam o ritmo de crescimento e as linhas de desenvolvimento do encarceramento no Brasil, é possível recorrer a alguns trabalhos que, com diferentes ênfases, discutem essas políticas e problematizam suas circunstâncias e consequiências.

Segundo Teixeira (2006), no sistema penitenciário brasileiro, o ideal de reabilitação foi incorporado tardiamente e abandonado precocemente; ou seja, não chegou, efetivamente, a orientar as práticas de diferentes agentes e instituições no interior do campo. Na esfera nacional, só na Lei de Execuções Penais (LEP) de 1984, o ideal de reabilitação se sobrepôs às funções retributivas da pena de privação de liberdade. Porém, segundo a autora, essas disposições legais permaneceram "letra morta", inaplicável devido à "inércia" dos poderes executivo e judiciário, que não criaram os dispositivos previstos para a implementação de programas de reabilitação nos presídios. Em São Paulo, a autora demonstra que o ideal de reabilitação chegou mais perto de se transformar em prática. Entre 1983 e 1986, o então Secretário de Justiça do Estado de São Paulo, José Carlos Dias, promoveu o que ficou conhecido como "política de humanização dos presídios". ${ }^{27}$ Além de prever a ampliação de vagas para diminuir a superlotação, a criação de visitas íntimas para a população carcerária masculina, a implementação de um programa de assistência jurídica; o secretário fomentava o estabelecimento de canais democráticos de representação da população carcerária junto à direção do presídio e outros órgãos governamentais. Os presos deveriam escolher seus representantes por voto direto e secreto, e debater coletivamente suas reivindicações, denúncias e propostas.

No contexto de redemocratização do país, essa ordem de propostas conferia um sentido muito concreto para o ideal de reabilitação dos presos. Porém, a resistência institucional dos estratos médios e inferiores do aparato estatal de justiça penal foi muito forte. As pressões sobre Franco Montoro - o primeiro governador democraticamente eleito em São Paulo, em vinte anos - fizeram-no destituir José Carlos Dias do cargo. A política de humanização dos presídios fracassava antes mesmo de ser efetivamente implementada. Portanto, no Brasil e em São Paulo, o abandono do ideal de reabilitação não é suficiente para explicar o aumento do encarceramento.

\footnotetext{
${ }^{27}$ Para uma discussão mais aprofundada acerca da política de humanização dos presídios, ver: SALLA (2007), CALDEIRA (1991, 2003) e GÓES (2004).
} 
Assim como o ideal de reabilitação - que nunca orientou efetivamente as práticas punitivas no Brasil - a ênfase no caráter retributivo da pena não representa uma alteração recente, ou um retorno atávico, mas uma constante, que se evidencia nas condições sempre precárias, nas práticas de tortura, maus-tratos e violência institucional que caracterizam o cotidiano do ambiente prisional, e que, desde a década de 1980, são amplamente registrados e denunciados. ${ }^{28}$ Também o caráter meramente incapacitante, excludente, e segregacional da prisão já era denunciado naquela década. Fischer e Adorno (1987) - em “Políticas penitenciárias, um fracasso?” - já afirmavam que, no Brasil, "o dilema entre recuperar e punir dissolve-se, em verdade, na constatação de que o sistema [penitenciário] constitui aparelho exemplarmente punitivo e funciona exclusivamente como depósito de corpos e mentes." (FISCHER e ADORNO, 1987, p.78 - grifo meu).

Não obstante essa rigidez punitiva que é praticamente constitutiva do sistema carcerário brasileiro, alterações legislativas também foram recentemente realizadas. Teixeira discute as circunstâncias da principal reforma legislativa em âmbito penal: a aprovação da Lei de Crimes Hediondos em 1989, que estendia a pena e revogava direitos previstos na LEP para uma ampla gama de delitos. A aprovação da lei em caráter de urgência, sem o devido debate parlamentar, em contexto eleitoral, sob forte pressão midiática e apresentada como uma reação contundente e imediata a casos de seqüestro que tiveram ampla repercussão, colocam-na em ressonância com as reformas nas políticas criminais que vinham promovendo o endurecimento penal em outros países ocidentais. A centralidade da figura da vítima, recorrentemente evocada para demandar e justificar medidas de endurecimento penal, também fica evidente em casos como o da atriz Daniella Perez - cujo assassinato, em 1992, alavancou a inclusão do homicídio qualificado na Lei de Crimes Hediondos ${ }^{29}$ - e em casos mais recentes, como o do casal Liana Friedenbach e Felipe Caffé, e do menino João Hélio - cujos homicídios

\footnotetext{
${ }^{28}$ Os relatórios de atividades da Comissão Teotônio Vilela (CTV) são uma importante fonte desses registros e denúncias, e estão disponíveis na internet via: http://www.ctvdh.org/portal/atuacao/relatorios/relatoriosdevisitas/ (Consulta feita em maio de 2010). ${ }^{29}$ cf. TEIXEIRA (2006) pp.95-100.
} 
envolviam indivíduos menores de idade e fomentaram todo um movimento social e parlamentar em prol do endurecimento penal para menores infratores. ${ }^{30}$

Para uma discussão sobre a cultura política que conforma as condições de possibilidade dessas práticas legislativo-judiciárias é possível recorrer aos trabalhos desenvolvidos no Núcleo de Estudos da Violência (NEV), na década de 1990. No relatório de pesquisa intitulado "Continuidade autoritária e construção da democracia", encontra-se uma síntese dessa longa reflexão. Segundo Pinheiro (1999, pp.40-73), Cardia (in PINHEIRO, 1999, pp.11-39) e Adorno (1998), no Brasil contemporâneo, o desafio teórico e analítico não é compreender a guinada punitiva e autoritária na cultura política de uma democracia consolidada, como nos Estados Unidos; mas, pelo contrário, analisar a continuidade das práticas autoritárias e discricionárias, próprias do longo período ditatorial, num contexto de abertura política e institucionalização democrática. Segundo Pinheiro (2001) - em "Transição política e não-estado de direito na República" - essa continuidade autoritária pode ser entendida nos termos de um autoritarismo socialmente implantado, que rege historicamente as relações entre as diferentes classes sociais no Brasil.

Porém, se por um lado, o autoritarismo socialmente implantado ajuda a compreender as condições de possibilidade do endurecimento penal e do aumento do encarceramento no Brasil, em tempos de consolidação democrática; por outro lado, sua constatação ainda é insuficiente. Se a cultura política brasileira sempre foi autoritária, resta a indagação sobre o que impulsiona o endurecimento penal e o aumento exponencial da taxa de encarceramento justamente no final do século XX.

Como é possível perceber, não se compreende suficientemente o endurecimento penal e o processo de massificação do encarceramento no Brasil atendo-se às formulações teórico-analíticas elaboradas para outros contextos, de países desenvolvidos - como considerando o declínio do ideal de reabilitação ou a erosão de um Estado de BemEstar, que aqui nunca prevaleceram. Por outro lado, tampouco será suficiente uma análise que se detenha no contexto local sem considerar deslocamentos transversais que se dão no campo do controle do delito, no mundo ocidental como um todo - como a

\footnotetext{
${ }^{30}$ Um exemplo de discurso público em prol do endurecimento penal que se baseia no "caso João Helio" é MEZAN (2010). Para uma análise sociológica da mobilização do "caso Liana e Filipe" para a realização de uma outra modulação de endurecimento penal, ver: MATSUDA (2009).
} 
emergência de políticas criminais-penitenciárias de revogação de direitos e ampliação das penas, que, embora conformadas segundo as idiossincrasias de uma cultura política particular, entram em ressonância, são aplicadas e replicadas em diversos contextos, seja em países desenvolvidos, seja naqueles em "vias de desenvolvimento". Tais considerações corroboram a perspectiva analítica que aqui se pretendeu adotar, buscando articular a reflexão sobre esses processos desde postos de observação suficientemente distantes.

\section{3 - Catalunha, Espanha}

Apesar de ser um país bastante desenvolvido, a Espanha figura na periferia do debate internacional sobre as tendências punitivas do mundo contemporâneo. Dos autores que pautam esse debate e que foram anteriormente citados, somente Wacquant e Christie fazem ligeiras referências a esse país ibérico. Wacquant afirma que, entre 1983 e 1995, a população carcerária na Espanha saltou de cerca de 14.000 presos para mais de 40.000 (WACQUANT, 2007, p.193). Christie ressalta que, em 1990, a Espanha era o sexto país europeu com a maior taxa de encarceramento (86/100 mil), atrás do Reino Unido, Luxemburgo, Alemanha, Turquia e Portugal (CHRISTIE, 2000, p.37). Ao chegar à península, cabia-me atualizar essas informações, precisando a escala e o ritmo do incremento do encarceramento no país e na região específica onde desenvolveria trabalho de campo: a comunidade autônoma da Catalunha, que é a única do Estado espanhol a administrar o seu próprio sistema penitenciário.

Segundo dados do Ministerio del Interior (2010a), em dezembro de 2007, a população reclusa na Espanha já era de 67.100 presos, dos quais 9.375 estavam na Catalunha. No fim de 2009, essas cifras são de 76.079 para a Espanha e de 10.531 para a Catalunha. Portanto, entre 1983 e 2009, a população carcerária na Espanha cresceu em 443,4\%. Segundo dados do Departament de Justícia (2010a) do governo da Catalunha, a taxa de encarceramento do estado espanhol passou de 115,7/100 mil habitantes, em 1999, para 166,9/100 mil, em 2009; no mesmo período, a taxa de encarceramento na Catalunha subiu de 95,8 para 140,8/100 mil habitantes. Ainda segundo o governo catalão, esses 
índices fazem da Espanha, em 2009, o país com a mais alta taxa de encarceramento da União Européia, e da Catalunha, a terceira maior taxa de encarceramento do bloco, ficando atrás somente do conjunto do estado espanhol ${ }^{31}$ e do Reino Unido. Esses indícios fazem dos casos espanhol e catalão dois dos mais proeminentes processos de massificação do encarceramento da Europa contemporânea.

Quanto à concentração social dos efeitos do encarceramento sobre determinados grupos da população - a segunda característica fundamental do processo de massificação do encarceramento, segundo Garland - é possível reafirmar a hipótese sustentada por Wacquant de que estrangeiros e "quase-estrangeiros" constituem a clientela preferencial dos sistemas punitivos dessas localidades. Segundo dados do Instituto Nacional de Estadística (INE, 2010a), em 1996, 17,3\% da população prisional da Espanha era nascida em outro país; em 2007, esse percentual sobe para $34,2 \%$. De acordo com o governo da Catalunha, em 1999, 19,8\% da população prisional da comunidade autônoma era de estrangeiros; e em 2009 essa cifra alcança o significativo patamar de 43,3\% (DJ, 2010a). O censo populacional do INE (2010b) mostra que, em 1998, apenas 1,6\% da população da Espanha era estrangeira; já em 2009 esse número sobe para 12,1\%; para a Catalunha, os dados são de 1,9\% de estrangeiros em 1998, e 15,9\% em 2009. A sobre-representação da população estrangeira no sistema penitenciário confirma a tese de concentração dos efeitos do aumento do encarceramento sobre esse grupo populacional. $\mathrm{O}$ quadro ficaria ainda mais agravante se fosse possível isolar no interior da população carcerária classificada como espanhola aqueles que são percebidos como estrangeiros, os "quase-estrangeiros", filhos e filhas de imigrantes.

Como já foi indicado, o sistema penitenciário espanhol é gerido pelo Ministerio del Interior nacional, e o catalão pelo Departament de Justícia da comunidade autônoma, tendo estruturas operacionais e administrativas distintas, ainda que funcionando sob uma mesma armadura jurídica. Segundo o Ministerio del Interior (2010b), atualmente existem 104 estabelecimentos penitenciários sob sua administração; sendo 67 Centros Penitenciários, 33 Centros de Inserção Social, 2 Unidades para Mães e 2 Hospitais Psiquiátricos Penitenciários. Segundo o Departament de Justícia (2010b), são 15 os estabelecimentos penitenciários da Catalunha; 9 Centros Penitenciários, 3 Centros

\footnotetext{
${ }^{31}$ A Catalunha é a segunda região da Espanha em encarceramento, ficando atrás somente da Andaluzia.
} 
Penitenciários Abertos, 1 Centro Penitenciário Feminino, 1 Centro Penitenciário de Jovens e 1 Hospital Penitenciário.

Em linhas gerais, o processo de endurecimento penal na Espanha vem sendo problematizado segundo o roteiro analítico formulado por Wacquant (2001): erosão do Estado de Bem-Estar Social, correspondente recrudescimento do Estado Penal principalmente através de reformas nas políticas criminais -, e progressiva criminalização de imigrantes estrangeiros pauperizados. Cid (2008) explora os impactos na taxa de encarceramento da reforma penal de 1995, que ampliava a utilização e a duração das penas de prisão para diversos delitos, e restringia o direito à redução da pena em função de trabalho ou outras atividades de tratamento. Neto (2009), por sua vez, aprofunda a análise do processo de desestruturação do aparato estatal de promoção do bem-estar social, analisando a relativa redução dos gastos públicos em proteção social, consoante à aprovação de diversas reformas penais no início dos anos 2000. E o Observatori del Sistema Penal i els Drets Humans (OSPDH, 2008) da Universidade de Barcelona (UB) publicou um estudo minucioso sobre cada grande e pequena reforma legislativa em matéria penal promovida entre 1995 e 2005, explorando seus contextos imediatos, seus objetivos declarados e os efeitos de endurecimento penal que representaram. O estudo ainda é aberto por uma abrangente análise das principais macro-transformações sociais, no mercado de trabalho e nos sistemas punitivos dos países desenvolvidos, apresentando a Espanha como um exemplar mais de um amplo processo marcado pela evolução de uma economia neoliberal, articulada ao desenvolvimento de políticas criminais-penitenciárias de intolerância. Encerrando a publicação, um artigo problematizando o horizonte penal baseado na exceção e na emergência que se apresenta no mundo ocidental contemporâneo.

Entre as muitas reformas penais analisadas, destaca-se um progressivo processo de criminalização da imigração ilegal, restringindo as possibilidades de regularização do imigrante, ampliando o recurso à expulsão do país ${ }^{32}$, e lançando mão dos Centros de Internamento de Estrangeiros (CIEs) para a reclusão administrativa de imigrantes clandestinos. Em Barcelona são dois CIEs operando atualmente, e somando-se ao conjunto de instituições fechadas estatais da Catalunha.

\footnotetext{
${ }^{32}$ Inclusive prevendo a expulsão do imigrante infrator em substituição a penas inferiores a seis anos de prisão, e após o cumprimento de $3 / 4$ de uma pena superior a seis anos.
} 
Também é digna de destaque a lei de 2002 que instituiu os julgamentos rápidos, como um imperativo legal para o processamento quase imediato (em questão de dias) de determinadas acusações, o que implicou uma significativa expansão (reestruturação) do aparelho de justiça estatal. A partir dessa lei, foram criados 80 novos juizados penais em toda a Espanha e foram contratados centenas de novos funcionários para operá-los, de tal modo que, nos cem primeiros dias de vigência do novo sistema, 45.000 julgamentos foram realizados.

Sobre a cultura política que conforma e sustenta essas medidas é possível identificar na bibliografia o problema de uma crescente preocupação pública com as questões de segurança, aliado à emergência de um discurso que associa o aumento da criminalidade ao aumento da imigração. Wagman $(2002,2003)$ é um dos sociólogos que identificam, criticam e denunciam essa cultura política que se aproxima da xenofobia. Segundo o autor, esse discurso se formula com base em pesquisas e dados oficiais que relacionam o aumento dos delitos e da imigração a partir do ano de 2001. O seu esforço é o de desvincular essas variáveis, mostrando que suas correlações são construídas ideologicamente, obscurecendo certos dados e processos particulares.

Wagman questiona a própria tendência de aumento da criminalidade, diferenciando criminalidade "real" de crimes registrados. Segundo o autor, o aumento de crimes registrados - apresentado como a mítica explosão da criminalidade de 2001 - decorre mais de uma reforma administrativa nos aparatos policiais e de segurança ocorrida em 2000, sob a alcunha de "Plan 2000". Através desse plano, imprimia-se uma nova lógica de gestão da segurança, mediante o estabelecimento de metas - de detenções, de apreensões, de julgamentos - para os diferentes agentes de controle do delito e justiça penal, condicionando suas remunerações aos respectivos índices de "produtividade".

Por outro lado, Wagman questiona a correlação entre delitos e imigração, explorando as estatísticas criminais. Segundo o autor, o Ministerio del Interior afirmava que 50\% dos delitos ocorridos em 2001 haviam sido cometidos por imigrantes, resultando na detenção de 116.139 estrangeiros - a metade dos detidos no período. Fracionando o dado pelas causas de detenção, Wagman descobriu que 50.748 estrangeiros haviam sido detidos por instância ilegal, ou seja, eram "presos" por causas administrativas, que não poderiam (ou não deveriam) ser identificados como delinqüentes. Ainda, dos 58.199 estrangeiros detidos por causas criminais, cerca de $40 \%$ eram turistas ou traficantes 
internacionais que não residiam na Espanha, e a maior parte dos $60 \%$ de estrangeiros residentes que cometeram delitos era acusada de crimes contra a saúde pública (tráfico de drogas) e não por crimes contra a propriedade.

Com base nessas e outras informações, Wagman discute o desenvolvimento de uma cultura política que equipara infrações administrativas, "delitos de papeles", tráfico de drogas e crimes contra a propriedade sob o mesmo rótulo da ameaça da imigração. Segundo o autor, essa difusa percepção social associada a um policiamento que funciona sob a égide do produtivismo acaba por provocar uma exagerada sobrerepresentação dos imigrantes estrangeiros na população carcerária espanhola. 


\section{3 - Vasos comunicantes}

No capítulo anterior buscou-se uma primeira aproximação dos sistemas punitivos e de seus respectivos problemas e desenvolvimentos recentes, no Brasil e na Espanha. Nesse capítulo, um segundo passo será dado, apresentando o que na introdução foi colocado como uma precaução metodológica estratégica para uma adequada abordagem do transbordamento da prisão e de seus efeitos societários. Trata-se de uma exploração dos vasos comunicantes que operam a conexão da prisão com outros territórios, e de algumas estruturações societárias que são produzidas em função dessas conexões. ${ }^{33}$

Em primeiro lugar, procuro evidenciar as dimensões societárias do problema, através de estimativas aproximadas do volume de agentes que acabam sendo arrebatados, direta e indiretamente, pela prisão em seus cotidianos. Em seguida, passo a explorar algumas modulações e características dessas conexões, bem como alguns processos de estruturação societária pautados por elas. Para finalizar o capítulo, problematizo as relações entre a noção de vasos comunicantes que procurei estudar, e de agentes mediadores que acabaram se constituindo como novo foco da pesquisa.

\section{1 - Estimativas}

Propõe-se aqui um exercício especulativo sobre as proporções e a evolução do volume de pessoas que encontram suas vidas afetadas direta e indiretamente pela prisão nas últimas décadas, nos dois contextos estudados. O raciocínio é simples: partindo do contingente da população carcerária num determinado momento, buscar-se-á estimar o número de pessoas direta e indiretamente afetadas pelo sistema penitenciário. Evidentemente, tal cálculo só poderá se realizar sobre postulados hipotéticos, que cabe agora explicitar. Considera-se diretamente afetado pelo encarceramento o preso e sua

\footnotetext{
${ }^{33}$ Esse capítulo é um desdobramento de artigo que apresentei em maio de 2009, em seminário organizado pelo PPGS-USP e NEV, “Crime, Violência e Cidade”, ver: GODOI (2009c).
} 
família mais próxima: sua mãe, seu pai, sua esposa ou namorada, e seu(s) filho(s). Levando em consideração que as estruturas familiares são altamente variáveis, que nem sempre todos esses componentes se verificam, que em alguns casos eles são mais numerosos, e em outros, praticamente inexistentes, postula-se hipoteticamente que, em média, para cada preso, quatro pessoas vivenciariam os efeitos diretos de seu encarceramento. Sem entrar no mérito da qualidade dos vínculos pelos quais essa vivência de afetação é transmitida a terceiros - produzindo pessoas indiretamente afetadas pelo encarceramento - postula-se hipotética e sumariamente que cada familiar diretamente afetado transmitiria e compartilharia alguns dos efeitos do encarceramento que lhe atinge com três diferentes pessoas de sua rede social. ${ }^{34}$ Trata-se de vizinhos, outros parentes, amigos de bairro, de trabalho ou de escola, que estariam desconectados da rede social que passa pela prisão, e são por esses vínculos a ela conectados, constituindo assim o grupo de pessoas indiretamente afetadas pelo encarceramento.

Portanto, esquematicamente, PC equivalendo à população carcerária numa determinada unidade espaço-temporal, 4PC equivaleria ao número de familiares atingidos pela prisão; 5PC seria o contingente de pessoas diretamente afetadas pelo encarceramento (presos e familiares); 12PC seria o volume de pessoas indiretamente afetadas (três contatos para cada familiar), e 17PC, o total de pessoas direta e indiretamente afetadas pelo encarceramento.

Se se atribui alguma razoabilidade a esses postulados hipotéticos e aproximativos, a partir dos dados da população prisional, é possível projetar as dimensões do grupo mais afetado pelo encarceramento em diferentes momentos no Brasil e em São Paulo, na Espanha e na Catalunha. E ainda - a exemplo do que já é feito com os índices de encarceramento - se se considera a população total em cada unidade espaço-temporal, é possível projetar uma taxa de afetação direta e indireta do sistema prisional por $100 \mathrm{mil}$ habitantes.

Brasil, 1988: o total nacional da população carcerária (PC) era de 88.041 (ADORNO e SALLA, 2007), de modo que a estimativa de familiares próximos (4PC) seria de 352.164; a estimativa de pessoas diretamente afetadas (5PC) seria então de 440.205; e a

\footnotetext{
${ }^{34} \mathrm{O}$ número três é intuitivo, parecendo-me reduzido o suficiente para não levantar questionamentos sobre as intersecções das redes sociais de componentes de uma mesma família. Em todo caso, admite-se que é altamente questionável esse postulado.
} 
estimativa de pessoas indiretamente afetadas (12PC) seria de 1.056.492. Somando os conjuntos de pessoas direta e indiretamente afetadas pelo sistema prisional (17PC) chega-se a cifra de 1.496.697. Segundo o IBGE (2006), em 1988, a população total brasileira era de 141.382 .535 , de tal modo que uma taxa nacional de afetação direta e indireta do sistema prisional seria de 1.058,6/100 mil habitantes. Em 2000, a população carcerária do Brasil já havia saltado para 211.953; de modo que as estimativas de familiares próximos, de pessoas diretamente, e indiretamente atingidas, seriam respectivamente: 847.812 (4PC), 1.059 .765 (5PC), e 2.543 .436 (12PC); totalizando 3.603.201 (17PC) pessoas direta e indiretamente afetadas pelo turbilhão do encarceramento - o que, considerando a população recenseada em $2000^{35}$, representaria uma taxa de afetação carcerária de 2.124,6/100 mil habitantes. Oito anos mais tarde, o número de encarcerados no Brasil já era de 440.013, os familiares, portanto, seriam 1.760.052, os diretamente afetados seriam 2.200.065, e os indiretamente afetados seriam 5.280.156, somando 7.480.221 pessoas. Se como afirma o DEPEN (2010), o total da população brasileira era de 256.385 .272 pessoas, a taxa de afetação seria de 2.917,5/100 mil habitantes, em 2008.

Faço o mesmo raciocínio com os dados disponíveis para o estado de São Paulo, que em 1986, contabilizava uma população carcerária de 24.091 pessoas (SALLA, 2007, p.74). A estimativa de familiares próximos, portanto, seria de 96.364 , a de pessoas diretamente afetadas seria de 120.455, e de pessoas indiretamente afetadas seria de 289.092, totalizando 409.547 pessoas direta e indiretamente atingidas pelo encarceramento. $\mathrm{O}$ IBGE (2006) estimava, para 1986, a população total paulista em 30.238.300, de modo que a taxa estadual de afetação carcerária seria de 1.354,3/100 mil habitantes - o que, não obstante a diferença de dois anos nos dados disponíveis, indicaria que, no estado de São Paulo, uma taxa de afetação direta e indireta do sistema prisional seria significativamente maior que a nacional. Seguindo com as estimativas essa tese se confirma. Em 1996, a população carcerária paulista já era de 66.278 (SALLA, 2007, p.83); a estimativa de familiares seria então de 265.112, a de diretamente afetados seria de 331.390, e a de indiretamente afetados seria de 795.336, totalizando 1.126.726 pessoas direta e indiretamente afetadas pelo encarceramento. Considerando a contagem da população estadual do IBGE (2006), 34.119.110 pessoas habitavam o estado de São

\footnotetext{
${ }^{35}$ Total de habitantes do Brasil, segundo o Censo Populacional de 2000: 169.590.693 (IBGE, 2010).
} 
Paulo nesse ano, de modo que a taxa de afetação seria de 3.302,3/100 mil habitantes. Em 2008, a população carcerária nos presídios paulistas já era de 158.447 pessoas (DEPEN, 2010); os familiares próximos seriam assim 633.788; os diretamente afetados seriam 792.235; os indiretamente afetados seriam 1.901 .364 pessoas; e a soma total de pessoas direta e indiretamente afetadas pelo encarceramento seria de 2.693.599, num estado habitado por 41.585.931 pessoas - o que implicaria numa taxa de afetação carcerária de 6.477,1/100 mil habitantes, ou seja, um índice mais que duas vezes maior que o índice nacional. Agora, lembrando que grande parte da população carcerária paulista é oriunda de bairros periféricos, principalmente dos grandes centros urbanos, seria possível afirmar, sem dificuldades, que em determinadas localidades essa taxa de afetação superaria o patamar dos 10.000/100 mil habitantes.

Espanha, 1990: segundo o Instituto Nacional de Estadística (INE, 2010a), a população carcerária nacional era de 33.058, de modo que a estimativa de familiares afetados pelo encarceramento seria de 132.232 pessoas; os diretamente afetados seriam 165.290, e os indiretamente afetados seriam 396.696; totalizando 561.986 pessoas direta e indiretamente afetadas pelo sistema prisional. Tomando por base a população recenseada em 1991 - 38.872.268 habitantes $^{36}$ (INE, 2010b) - seria possível afirmar que o índice nacional de afetação prisional, no começo da década de 1990, estaria por volta de 1.445,7/100 mil.

Quase vinte anos depois, em 2009, a população carcerária da Espanha já era de 76.079 (MI, 2010a). Portanto, seria de 304.316 a estimativa do contingente de familiares de presos; 380.395 seriam os diretamente afetados pela prisão; 912.948 seriam os indiretamente afetados; e 1.293.343 seriam os direta e indiretamente afetados pelo encarceramento. Considerando a estimativa do INE (2010b) para a população total - de 45.983.364 habitantes - o índice de pessoas direta e indiretamente afetadas pelo sistema prisional na Espanha seria de 2.812,6/100 mil habitantes.

Na Catalunha de 1990, a população carcerária era de 4.749 (DJ, 2010a), de modo que os familiares de presos totalizariam 18.996 pessoas; os diretamente afetados pela prisão seriam 23.745; os indiretamente afetados seriam 56.988; e o total de afetados seria de 80.733. Se a população total da Catalunha em 1991 era de 6.059.494 (INE, 2010b), no

\footnotetext{
${ }^{36}$ Não foi possível encontrar o dado sobre a população total na Espanha em 1990.
} 
começo da década de 1990, o índice de afetação prisional estaria por volta de 1.332,3/100 mil habitantes. Em 2009, a população carcerária era de 10.531 (MI, 2010a), os familiares seriam 42.124, os diretamente afetados seriam 52.655, os indiretamente afetados seriam 126.372, e o total seria de 179.027 pessoas. Cruzando essa estimativa com a do INE (2010b) para a população total da Catalunha - de 7.301.953 habitantes -, chega-se a um índice de afetação carcerária de 2.451,7/100 mil.

Porém, pela aproximação que já se fez do contexto penitenciário espanhol e catalão, sabe-se que a população total não é a referência mais adequada para se imaginar um índice de afetação carcerária, uma vez que existe uma significativa sobre-representação dos imigrantes estrangeiros no contingente penitenciário. Com o mesmo ânimo de exercício especulativo, proponho então fazer os mesmos cálculos com base na população carcerária estrangeira de 2009, na Catalunha, que era de 4.560 pessoas (DJ, 2010a). Assim, os familiares de presos estrangeiros totalizariam 18.240 pessoas, os estrangeiros diretamente afetados pelo encarceramento seriam 22.800, os indiretamente afetados somariam 54.720; e os direta e indiretamente afetados seriam 77.520. Se, ao invés da população total da Catalunha, tomar-se como referência apenas a população estrangeira - que em 2009 era de 1.061.079 pessoas (IDESCAT, 2010) - chega-se ao índice de afetação carcerária de 7.305,7/100 mil habitantes estrangeiros.

Apesar de essa estimativa reproduzir a sobre-representação das populações estrangeiras no interior do aparato penitenciário catalão deve-se reconhecer que ela tampouco expressaria, mesmo que de forma aproximada, o campo de afetação prisional no interior das populações estrangeiras. Em primeiro lugar, porque a estrutura familiar e as redes sociais dos imigrantes estrangeiros são por demais diversas das que aqui se postulou hipoteticamente, principalmente por remeterem também aos países de origem. ${ }^{37}$ Nestes termos, a rede de pessoas direta e indiretamente afetadas pelo encarceramento espanhol e catalão seria uma rede transnacional, que passa por países como Marrocos, Colômbia, Romênia, Equador, Argélia, etc. ${ }^{38}$ Ou seja, a partir e ao redor da prisão espanhola estrutura-se um campo internacionalizado de agentes, bastante difícil de precisar através dessas estimativas hipotéticas.

\footnotetext{
${ }^{37}$ Para uma discussão sobre as relações familiares e as redes sociais dos imigrantes estrangeiros na Catalunha, ver: RODRÍGUEZ, SANS e SOLANA (2006).

${ }^{38}$ Esses são os cincos países de origem mais freqüentes da população carcerária estrangeira na Catalunha. Para mais informações, ver: DJ (2010a).
} 
É evidente que as estimativas e estas imaginadas taxas de afetação carcerária não têm a pretensão da precisão científica. Tanto para São Paulo, quanto para a Catalunha, trata-se mais de aproximações iniciais que visam evidenciar a escala de um campo social no qual um número bastante significativo (e crescente) de agentes vem sendo interpelado pelo encarceramento, obrigados a lidar com a prisão e seus meandros, levados a vivê-la e a dizê-la.

Se se agregasse ao escopo dessas aproximações estimativas, o contingente dos agentes estatais que também têm a vida estruturada ao redor da prisão, os cálculos seriam outros; o mesmo se se agregasse uma multiplicidade de agentes da sociedade civil, de militantes dos direitos humanos, de voluntários religiosos, etc., cujas vidas também são afetadas pelo mundo prisional. Em suma, o campo que se pretende analisar é expansivo e indeterminável, essas estimativas vieram tão somente para indicar que ele existe e que, cada vez mais, é por demais importante. Agora cabe explorar melhor alguns aspectos do como ele se estrutura e do que ele produz.

\section{2 - Os vasos comunicantes}

Duas ressalvas devem ser feitas para iniciar uma discussão sobre os vasos comunicantes que conectam a prisão a outros territórios, fazendo a prisão afetar direta e indiretamente a vida de pessoas que estão em liberdade e não necessariamente cometeram um delito. Em primeiro lugar, os vasos comunicantes sempre existiram na prisão, de tal forma que sua atual importância não decorre da novidade. Em segundo lugar, sua importância tampouco decorreria meramente do aumento pronunciado da população carcerária, que intensifica os fluxos de pessoas, coisas e dizeres que gravitam ou transitam por esses vasos.

É preciso bem reter as sugestões teórico-analíticas de Cunha (2002, 2004, 2004-2005) sobre o processo de erosão das fronteiras entre bairros e prisões, que apontam para todo um rearranjo no dispositivo carcerário que ressitua a prisão e sua "natural" porosidade num novo jogo de ralações. Um rearranjo que se refere: 1 - a deslocamentos 
importantes na economia dos ilegalismos populares, principalmente com a evolução recente do mercado de drogas e suas implantações territoriais; 2 - ao respectivo desenvolvimento de novas políticas criminais, pautadas por uma concepção de "guerra contra as drogas", que privilegiam o "ataque" aos espaços e agentes que operacionalizam o varejo desse comércio ilegal; e 3 - às respectivas reconfigurações de sociabilidades locais, que requalificam, de um lado, as práticas ilegais como alternativas mais viáveis de geração de renda, e de outro, a experiência prisional como um expediente de socialização amplamente compartilhado, que já não isola nem estigmatiza sujeitos classificados como desviantes. $\mathrm{Na}$ articulação desses fatores mais do que o próprio perfil da população carcerária se alterar, alteram-se também as dinâmicas de interação e relacionamento entre o dentro e o fora da prisão, os tempos sociais de dentro e de fora se sincronizam, as posições de preso, visitante, familiar e/ou amigo se desestabilizam, tornam-se condições provisórias, intermitentes, de modo que os repertórios de saberes e práticas de cada lado dos muros progressivamente se equiparam.

Não foi possível identificar pesquisas no Brasil que desenvolvam a perspectiva de erosão das fronteiras prisionais sugerida por Cunha para o contexto português. Todavia, Buoro (1998), ao desenvolver uma pesquisa sobre as representações acerca dos direitos e da justiça para os familiares de presos, pelos imperativos do trabalho de campo, acaba dialogando com o horizonte de questões que aqui se coloca. Sua investigação foi desenvolvida a partir das filas de espera que se formam a cada fim de semana diante dos presídios. Freqüentar as filas às portas da Casa de Detenção de São Paulo, entre 1992 e 1995, era uma estratégia para estabelecer contatos com o grupo social cujas representações pesquisava. Não obstante, a autora faz certas reflexões que tangenciam a problemática aqui levantada, como é possível perceber na seguinte assertiva:

"Atravessar as fronteiras entre o lado de dentro e o lado de fora da instituição é tarefa dos familiares de presos nos dias de visita. A partir da experiência dos familiares de presos podemos constatar que a'ordem pelo avesso` própria a um estabelecimento prisional, transborda para fora de seus vigiados muros." (BUORO, 1998, p. 106)

A autora faz referência direta ao trabalho de Ramalho (2002), desenvolvido duas décadas antes no mesmo presídio (do lado de dentro); e indica questões que coloco no 
foco da reflexão. Em primeiro lugar, que ainda que seja "avessa" ou "invertida", há uma ordem que se estrutura onde se imagina encontrar não mais que desordem e desestruturação. Em segundo lugar, aponta o familiar enquanto agente mediador, e o dia de visita enquanto vaso comunicante fundamental, que operam e possibilitam esse processo de estruturação societária que se estende para além dos muros da prisão. No decorrer do trabalho, a autora ainda aponta outras questões que são de interesse fundamental. Buoro sumaria sete tipos "de redes de relações que unem presos, familiares e funcionários e estes todos a alguns comerciantes dos arredores." (BUORO, 1998, p.89) Redes que articulam:

“a) presos-funcionários-comerciantes-familiares, b) funcionárioscomerciantes, c)ambulantes-presos-familiares, d)familiares-presosfamiliares, e)presos-cúmplices-familiares, f)familiares-familiares." (BUORO, 1998, pp.89-90)

Para cada uma dessas redes identificadas, a autora traz relatos de episódios vistos ou contados, nos quais se evidencia que a prisão pontua e articula o cotidiano desses diversos agentes. Mais do que cada episódio em particular, o que por enquanto importaria reter é o conjunto de agentes identificados nessas diversas redes que, no limite, articulam-se em uma só: presos, funcionários, comerciantes, ambulantes, cúmplices e familiares. Além dos "nós" que compõem a rede, a autora ainda sugere alguns dos suportes que produzem e atualizam os vínculos: as cartas; o "jumbo" e as diversas mercadorias que o compõem, ajudas diversas (materiais, financeiras e afetivas), passagens e viagens que antecedem uma visita, e "esquemas" variados (que vão desde uma "inobservância" a certas regras da visitação até a operacionalização do comércio de drogas na prisão e/ou no bairro).

Em torno de alguns casos conhecidos - no material editado durante a Iniciação Científica e em casos identificados no decorrer do trabalho de campo - diversos episódios também permitiam entrever a estruturação de uma rede ampliada de laços e cumplicidades, nas quais convergiam, inclusive, pessoas que nunca chegaram a visitar uma instituição prisional, ou nem sequer conheceram diretamente alguém que estava ou esteve preso. Não obstante, esses agentes podiam entrar em contato com importantes elementos que compõem o universo prisional, chegando a alterar o seu cotidiano e suas práticas sociais em função da prisão. 
Um grande volume de contatos é mobilizado para que um visitante chegue no horário devido, e devidamente munido de um "jumbo", na porta do presídio num dia de visita. Colegas de trabalho trocam de turno para que uma delas visite o marido na prisão. Enquanto essa mulher trabalha, uma vizinha faz a comida, outra faz um bolo, sua irmã reúne tudo e arruma o "jumbo" que será levado, no dia seguinte, ao cunhado preso. O preso sabe de todos esses movimentos, e ainda que não conheça pessoalmente todas as pessoas que concorrem para viabilizar os dias menos dolorosos do cumprimento de sua pena, ele as agradece e estabelece vínculos, diretos ou indiretos, com cada uma delas. Vínculos são criados ainda entre essa rede, que se articula em torno da visita e do "jumbo" do lado de fora, e a rede que se organiza em torno do preso no interior da prisão. Os “jumbos" são sempre montados com excesso de mantimentos, justamente para que possa ser dividido com os outros presos da cela do visitado, que por ventura não recebam nem visitas, nem "jumbos". Por exemplo, uma vizinha que montava o "jumbo" para uma visitante, soube que as comidas que fazia eram muito admiradas pelos dois companheiros de cela do visitado, que não estabeleciam contatos diretos com pessoas de fora. Numa ocasião, ao invés de montar um, montou três "jumbos", que foram levados pela visitante. Tal ato de solidariedade implicou tanto no fortalecimento dos vínculos entre o visitado e seus companheiros de cela, quanto entre o visitado e a vizinha da visitante, como entre a vizinha da visitante e os companheiros de cela do visitado, que a agradeceram na forma de seguidas mensagens, cartas e telefonemas. Portanto, prospectando o processo social de produção do "jumbo", poderíamos incluir no sumário de nós dessa rede social a figura dos amigos e vizinhos de familiares de presos, e assim identificar outros dois segmentos da rede que se estrutura a partir da prisão: um segmento presos-familiares-amigos e vizinhos de familiares; e outro presosamigos e vizinhos de familiares.

O estabelecimento (estruturação) dessas modalidades de vínculos em torno do "jumbo" coloca em evidência a centralidade desse artefato no dispositivo carcerário paulista. $\mathrm{O}$ "jumbo" e as amplas estruturações societárias ao seu redor são mobilizados para contornar ou amenizar as agruras de uma experiência carcerária que é absolutamente precarizada, que se dá nos limiares da violência fatal, na multiplicação dos maus tratos, na péssima alimentação, na indisponibilidade de serviços médicos e materiais de higiene. O que está em jogo no "jumbo" que entra na prisão e nas estruturações 
societárias que o produzem é um patamar mínimo de sanidade física e mental dos detentos, recebam eles visitas ou não. Sem uma "instituição" social como o "jumbo", a vida num presídio paulista seria inviável.

Mas não só a vida do preso é viabilizada pela mobilização dessas amplas redes, a vida de seus familiares também o é. Buoro relata episódios em que mulheres se solidarizavam com outras menos afortunadas, dando-lhes recursos para que regressassem a casa, alimentassem os filhos durante a longa espera na fila, etc. ${ }^{39} \mathrm{Em}$ campo, também pude identificar arranjos semelhantes, seja para viabilizar a ida de uma familiar a um presídio no fim de semana, seja para viabilizar a própria alimentação da mulher e dos filhos de um preso no decorrer da semana.

Com a construção de diversas penitenciárias em distantes cidades do interior paulista, e o correspondente aumento do tempo necessário e das distâncias percorridas para viabilizar as visitas, esse arranjo social que se estrutura ao seu redor se complexifica ainda mais. Da arrecadação de dinheiro para pagar uma passagem de ônibus, e de encontros casuais de familiares de presos numa rodoviária - eventos relatados por Buoro -, passa-se à necessidade de fretamento de ônibus, e à estruturação de um verdadeiro sistema (informal) de transporte estadual, que conecta os grandes centros urbanos às cidades do interior. Já não basta às visitantes organizarem a fila e solidarizarem-se com as menos afortunadas, passa a ser necessário promover semanalmente verdadeiras excursões para diversas cidades. A cada fim de semana, muitos ônibus fretados partem de pontos como o terminal rodoviário da Barra Funda, ou como a estação Carandiru do metrô. Emerge assim a figura da "guia", visitante que organiza o fretamento de ônibus para algum presídio interiorano. A ela cabe distribuir os assentos, reservar ou indicar pousadas, zelar pelos horários de partida e chegada, e etiquetar as bagagens - para que se saiba de quem é cada mala, em caso de, numa blitz policial, encontrarem drogas e armas no interior do bagageiro. Os serviços prestados são recompensados com a possibilidade de viajar sem pagar, por isso, muitas vezes são escolhidas para tal função justamente aquelas, entre as mais respeitadas, que apresentam maiores dificuldades financeiras. ${ }^{40}$ Ademais, com a interiorização dos presídios, entram na vasta rede social penitenciária, os motoristas e empresas de ônibus, os empresários

\footnotetext{
${ }^{39}$ cf. BUORO (1998) p. 93-94.

${ }^{40}$ Para uma descrição da "guia”, ver: JOZINO (2008), pp. 25-32.
} 
do setor hoteleiro das pequenas e médias cidades, os comerciantes de estrada, os policiais rodoviários, etc.; ao mesmo tempo em que se intensificam os vínculos entre as familiares - que além de compartilharem o tempo de espera na fila, passam a dividir horas e horas na estrada e a se comunicarem continuamente para verificação das vagas disponíveis, dos horários e pontos de partida, dos custos da viagem, etc.

Mas, as conexões entre presos, amigos e familiares não são operadas somente pelas visitas e pelos "jumbos". As cartas sempre foram e ainda são um vaso comunicante fundamental. Todos os dias podem ser enviadas e recebidas; a todo momento podem ser lidas ou escritas. Por meio delas, o preso abstrai a prisão e se coloca em relação com o mundo para além das muralhas. Muitos são os relatos autobiográficos de ex-presidiários que expressam a importância fundamental das cartas na vida dentro da prisão. ${ }^{41}$ Aqueles presos que escrevem bem, fortalecem os seus vínculos com outros presos, escrevendo cartas para parentes, amigos e vizinhos dos companheiros, promovendo os vínculos destes com suas redes externas de apoio. Muitas relações afetivas entre presos e pessoas livres passam por uma troca de cartas, uma troca de fotos, um convite escrito para a visita de fim de semana. Se completamente desconectado, jornais e revistas oferecem espaço para que o preso anuncie seu interesse em comunicar-se. A carta é também um vaso comunicante dotado de ambigüidades, nelas poderão ocultar-se mensagens secretas, relacionadas a ilegalismos variados. São, portanto, foco de especial atenção da parte do corpo de funcionários. As correspondências podem ser monitoradas, propositalmente desviadas, rasgadas ou ocultadas, com objetivos de investigação, de castigo ou de extorsão. De todo modo, com o passar dos anos, a correspondência postal não é o único vaso comunicante que opera a conexão entre pessoas presas e livres através de um suporte material: os proliferantes telefones celulares vêm ocupando a posição que era da carta, e superando-a em suas virtualidades - assim como vem ocorrendo na sociedade mais ampla.

Na prisão, da mesma forma que as cartas, os celulares tanto podem servir para (quase) inocentes conversas entre amigos e familiares, quanto para os ilegalismos mais variados, como para monitoramento e investigação policial. Trata-se, portanto, de um importante vaso comunicante que, não obstante sua ilegalidade, conecta pessoas presas e livres para os mais diversificados fins. Parece-me importante incluir esses aparelhos

\footnotetext{
${ }^{41}$ Ver, por exemplo: MENDES $(2001,2005)$ e JOCENIR (2001).
} 
no rol de vasos comunicantes, pois esses artefatos tecnológicos radicalizam a erosão das fronteiras das prisões, impulsionando de maneira determinante o fluxo de informações no interior das redes de pessoas direta e indiretamente afetadas pelo encarceramento; e colocando em cheque a capacidade de os presídios funcionarem, minimamente, como um dispositivo de contenção e incapacitação de criminosos, uma vez que, através deles, presos podem seguir gerenciando com ampla mobilidade o cotidiano de seus empreendimentos ilegais, e ainda desenvolver e aplicar novos golpes, como o do "falso seqüestro". ${ }^{42}$ Pode-se entender o celular no ambiente prisional como um importante vaso comunicante e um vetor do fracasso de uma prisão que pretende funcionar como incapacitante.

É possível conceber também a própria saída de um preso do ambiente institucional, sua volta para a localidade de origem, como o traçado de um vaso comunicante, que coloca aquele território para onde o egresso se dirige em contato com a prisão, através da sua mediação. Seja com um alvará de soltura, numa saída temporária ou mesmo numa fuga, ao sair do presídio, o preso inscreve com o próprio corpo uma linha de comunicação entre a realidade prisional e o ambiente urbano mais amplo, através da qual se difundem importantes elementos da experiência carcerária.

Assim como quando uma pessoa está presa, quando ela sai da prisão, para viabilizar as mínimas condições de vida, tem que buscar amparo na sua rede de relações mais próxima. Vínculos antigos e novos são mobilizados para providenciar a sua instalação no bairro, bem como a sua reinserção no mercado de trabalho, seja ele formal, informal ou ilegal. Nesses contatos, compartilham-se detalhes da experiência prisional inclusive aqueles que não convinham mencionar num dia de visita - atualizam-se vínculos sociais, fortalecendo e/ou expandindo ainda mais a rede de pessoas direta e indiretamente afetadas pela prisão.

Para explorar as características e ambigüidades desses vasos comunicantes que se constituem a partir do próprio corpo do preso, descrevo brevemente suas diferentes modulações. Em primeiro lugar, a fuga, que, por princípio, é um procedimento ilegal. Ela pode ser produto da engenhosidade de um grupo de presos, que cavam um túnel ou

\footnotetext{
${ }^{42}$ Sobre o o golpe do "falso seqüestro", ver: FOLHA ONLINE. "Polícia flagra presos praticando o golpe do falso seqüestro no Rio." in Cotidiano, 17 de maio de 2007, [on line] disponível na internet via: http://www1.folha.uol.com.br/folha/cotidiano/ult95u135524.shtml (Consulta feita em maio de 2010).
} 
pulam uma muralha; ou pode ser fruto de uma negociação com determinados agentes estatais sobre sua facilitação. ${ }^{43}$ No decorrer das décadas de 1990 e 2000, outras possibilidades de constituição desse vaso comunicante se desenvolveram, passando a envolver, cada vez mais, "cúmplices" que estão do lado de fora das muralhas. Ações de resgate, perpetradas em presídios ou em veículos de transporte de presos (conhecidos como "bondes"), e túneis discretamente cavados de fora para dentro da prisão aumentaram as possibilidades e dimensões das evasões nos últimos anos. ${ }^{44}$ Ainda que o fugitivo, geralmente, não volte para seu bairro de origem, e nem fortaleça os vínculos sociais com as pessoas que se viram afetadas pelo seu encarceramento; seguramente, determinados nós de sua rede social são acionados para viabilizar sua ocultação, e, sabendo disso, as forças policiais incidem especialmente sobre essa rede para chegar a alguma informação sobre o paradeiro do fugitivo.

A saída temporária, por sua vez, é um direito garantido pela LEP aos presos que já cumpriram boa parte de suas penas e não apresentam problemas disciplinares. Nos dias das mães, dias dos pais, páscoas e nas épocas de Natal, principalmente, esses presos deixam temporariamente o presídio e passam alguns dias em liberdade, entre familiares e amigos. Nesses breves períodos, verdadeiros eventos sociais se desenrolam nos bairros periféricos da cidade de São Paulo. Festas e reuniões são organizadas em torno da figura do preso, de modo que lhe é possível entrar em contato direto com conhecidos que usualmente não o visitam na prisão, ou mesmo, com pessoas que foram integradas à sua rede de relações, mas que ele ainda não tivera oportunidade de conhecer pessoalmente (e o que era mediado torna-se direto). Segundo relatos recolhidos em trabalho de campo, durante o desenrolar da saída temporária, entre festas, visitas e passeios, o preso experimenta, ambiguamente, a alegria de se ver livre, o desespero da volta iminente ao presídio, e a tensão de ser visado pelos agentes estatais da extorsão, os quais sabem que uma apreensão numa ocasião como essa pode implicar em significativo atraso na conquista da liberdade definitiva.

A saída temporária, portanto, pode acabar de três maneiras: 1 - como uma fuga, se o preso decide não retornar à prisão; 2 - como um novo aprisionamento, se o preso

\footnotetext{
${ }^{43}$ Sobre facilitação de fugas através da corrupção de agentes estatais, ver, por exemplo: FOLHA ONLINE. "Delegado, carcereiro e advogado são condenados por fuga em cadeia" in Cotidiano, 11 de junho 2003, [on line] disponível na internet via: http://www1.folha.uol.com.br/folha/cotidiano/ult95u76598.shtml (Consulta feita em maio de 2010). ${ }^{44}$ Para relatos jornalísticos de ações de resgate e fugas massivas, ver: SOUZA (2007) e JOZINO (2005).
} 
aproveita a ocasião para empreender uma ação ilegal e é mal sucedido, ou se ele é surpreendido pelos agentes da extorsão e não consegue negociar um "acerto"; ou 3 como um triste e, ao mesmo tempo, esperançoso retorno à unidade prisional.

Por fim, a liberdade, que também pode ser vista como uma via de comunicação e um meio de difusão da experiência penitenciária no tecido social mais amplo. $\mathrm{O}$ apoio de parentes, amigos e vizinhos é fundamental no processo de readaptação do egresso à vida em liberdade, e nesse processo toda a rede social que se articula ao seu redor se mobiliza e se reestrutura.

Como se sabe, a vida de um egresso do sistema prisional é bastante difícil. Por isso, existem ex-presidiários que nem cogitam a hipótese de tentar outra carreira fora do crime, existem aqueles que nem cogitam voltar para o crime, e existem aqueles muitos que, com o passar do tempo, vêem os projetos de vida honesta, feitos e refeitos a cada dia de aprisionamento, esfacelarem-se perante a realidade. $\mathrm{O}$ estigma de ex-presidiário faz com que as oportunidades no mercado de trabalho formal sejam mínimas, e a informalidade e os ilegalismos se apresentam como alternativas para aqueles que querem reduzir a sua condição de dependência material frente à sua rede social de apoio. De todo modo, a viabilização da vida do egresso, seja através da sua reinserção no mercado de trabalho formal, seja no informal, seja no ilegal, depende, invariavelmente, dessa rede social, de suas condições, possibilidades e articulações.

Invariavelmente também, e assim como acontece com aqueles que estão sob saída temporária, policiais corruptos reconhecem, observam e perseguem os ex-presidiários com o objetivo de extorqui-los, sob a ameaça de prendê-los por um motivo qualquer, real ou imaginário. Esse é mais um elemento determinante (e geralmente ignorado) que empurra o ex-presidiário para a reincidência. Em suma, se o mercado de trabalho formal resiste a incorporar o ex-presidiário pelos seus "antecedentes criminais"; se o mercado de trabalho informal o expõe à ação dos agentes da extorsão; se, sem conseguir trabalhar (formal ou informalmente) o egresso vê sua rede social de apoio seguir pagando propinas em seu nome, e no limite, garantindo as condições mínimas para a sua existência, tal e qual acontecia enquanto estava preso; se, por outro lado, no mercado de trabalho ilegal proliferam as oportunidades e convites - tanto pela experiência adquirida na prisão, quanto pelos inúmeros contatos ali estabelecidos muitas vezes, ao ex-presidiário resta escolher entre um ou outro artigo do código penal. 
Segundo relato recolhido em trabalho de campo, essa escolha perversa é feita levando em consideração alguns critérios, como o artigo em que já se tem alguma condenação ${ }^{45}$, aquele que promove maiores ganhos com menores riscos, e o que amplia as oportunidades de negociação de "acertos" com as forças policiais corruptas. Desse modo, um egresso que foi assaltante pode tornar-se traficante, um que foi traficante pode tornar-se receptador, um que furtava pode vir a seqüestrar, e assim por diante, conforme os cálculos e possibilidades de cada um. É nestes termos que a experiência prisional captura a vida de pessoas diretamente afetadas pelo encarceramento numa trama de ilegalismos e violência, que só fornece como horizonte a morte, a prisão ou a invalidez. E, no Brasil e em São Paulo, é esse horizonte cerrado que o dispositivo carcerário vem impondo para um número cada vez maior de pessoas.

Apenas por essa breve e esquemática exploração dos conectores de bairros a prisões em São Paulo, e de um muito variável campo de agentes, práticas e discursos que se estrutura ao seu redor, já é possível sugerir que a erosão das fronteiras entre bairros e prisões, a sincronização dos tempos prisional e urbano, também são verificáveis no contexto paulista. De todo modo, mais do que esgotar o exercício prospectivo de vasos comunicantes e estruturações societárias, o que se pretende nesse capítulo é apontar para essa ampla circulação de repertórios, de códigos, de linguagem, de problemas que fazem transbordar a prisão para além dos seus limites institucionais.

\section{3 - Mediadores}

$\mathrm{Na}$ Catalunha, importantes vasos comunicantes e estruturações societárias ao seu redor também puderam ser identificados. Visitas, cartas, telefonemas, serviços de "paquetería"46, saídas de "permisos"47 e de "tercer grado" também colocam em ressonância os cotidianos e repertórios de pessoas presas e livres. Aisa, nascida em

\footnotetext{
${ }^{45}$ Segundo o informante, se se é condenado duas vezes, em diferentes ocasiões, pelo mesmo artigo, a segunda pena é agravada significativamente.

${ }^{46}$ O equivalente ao "jumbo" brasileiro.

${ }^{47} \mathrm{O}$ equivalente à saída temporária brasileira.

${ }^{48} \mathrm{O}$ equivalente ao regime semi-aberto no Brasil.
} 
1987, e concebida numa visita íntima de uma prisão madrilenha, é quem me relatou a importância desses vasos comunicantes na sua socialização e na estruturação de sua família. ${ }^{49}$ Ela é filha de uma catalã e de um "quase-estrangeiro" francês, descendente de argelinos. Como já foi anteriormente indicado, sua relação com o pai - e também com a família paterna - só se manteve positiva e relativamente estável enquanto ele esteve preso. A partir do momento em que a relação parental deixou de ser mediada pelos vasos comunicantes da instituição prisional, ela se rompeu.

Apesar de ser uma trajetória bastante sugestiva para a reflexão sobre os processos de estruturação societária pautadas pelos vasos comunicantes da prisão, não tive a oportunidade de ir muito além do que me era relatado por Aisa. Aisa viveu o aprisionamento de seu pai em Terrassa, na coroa periférica de Barcelona. Ele, depois de um período preso na Espanha, foi transferido para cumprir pena na França, de onde Aisa carrega suas primeiras recordações penitenciárias. Por isso, Aisa tinha uma espécie de vida dupla. Em Terrassa, para evitar o estigma, ela e sua família omitiam o encarceramento do seu pai, de modo que as estruturações societárias que eram pautadas por esse aprisionamento, restringiam-se a arranjos familiares mais ou menos estendidos e inter-geracionais; por outro lado, na França, os vínculos que haviam sido urdidos nas rotineiras visitas já haviam se debilitado quando entrei em contato com essa informante privilegiada. Ou seja, os vasos comunicantes eram-me apresentados pela mediação do relato de Aisa de um passado recente.

Essa figura do mediador foi ganhando centralidade no decorrer da pesquisa. Na Catalunha e também em São Paulo, a prospecção dos vasos comunicantes se dava através dos relatos desses agentes que transitavam entre o dentro e o fora da prisão. E na busca de um bairro em que pudesse observar e etnografar as estruturações societárias pautadas pelos vasos comunicantes em sua atualidade, cada vez mais mediadores iam se inserindo no escopo da pesquisa. Além de egressos, familiares e amigos de presos - e com a intenção de contatar mais egressos, familiares e amigos de presos que estruturavam uma vida social pautada pela prisão num bairro com altos índices de encarceramento - passei a buscar outros mediadores, diferentes profissionais e operadores do sistema penitenciário, especialistas de diversas áreas, militantes defensores dos direitos humanos, voluntários, etc. Nessa incessante busca pelos vasos

\footnotetext{
${ }^{49}$ Para uma problematização mais detida sobre a trajetória de vida de Aisa, ver: GODOI (2008b).
} 
comunicantes operando, e através do contato com diversos mediadores, foi se ampliando a imagem do campo societário que se estruturava em ambiente aberto pautado pela prisão. Vislumbrou-se, então, um vasto campo político em torno do encarceramento, no qual se articulava uma miríade de agentes, práticas e discursos que faziam a prisão transbordar, não só para um bairro localizado, mas para territorialidades difusas, para diversos pontos do tecido social. Ademais, as experiências desses agentes mediadores além de atestar a porosidade das instituições prisionais, pareciam expressar muito concretamente os dilemas postos pelas práticas punitivas e suas evoluções recentes em cada contexto estudado. Em decorrência dessa progressiva centralidade que a figura do mediador foi tomando na pesquisa, o eixo de questões que se aqui se pretende contemplar se deslocou. Para esclarecer essa passagem, cabe uma apresentação do trabalho de campo empreendido, com uma apreciação mais detida dos obstáculos encontrados e dos percursos e contornamentos realizados em cada contexto. Esse é o objeto do próximo capítulo. 


\section{4 - Percursos de campo}

\section{1 - Em Barcelona}

A expedição etnográfica à Espanha, e especificamente à região metropolitana de Barcelona, de imediato, foi pensada como uma feliz contingência. Contingente pela disponibilização dos recursos materiais necessários ${ }^{50}$ para uma investigação que, àquela altura, formulava-se como estrategicamente comparativa. E feliz por diversos motivos. Em primeiro lugar, por ser identificável nesse país europeu um muito relevante processo de massificação do encarceramento, que, portanto, possibilitaria uma reflexão fecunda sobre os seus efeitos societários em contextos suficientemente distantes. Em segundo lugar, feliz por nesse país não ser observável nem a sombra de algo análogo às facções prisionais, fenômeno que, na ocasião, ainda era percebido como um elemento perturbador da pesquisa no contexto paulista. Entendia-se que a facção era uma estruturação societária que, apesar de certamente pautada pelos vasos comunicantes que conectam a prisão a outros territórios urbanos, parecia misturar demasiadamente outros elementos estruturantes irredutíveis à presença da prisão num bairro periférico, particularmente elementos próprios ao desenvolvimento do "mundo do crime", do "tráfico de drogas", da "corrupção", do "crime organizado" - estruturações e questões sobre as quais não se pretendia focar a pesquisa. Barcelona seria, então, um bom contexto para desenvolver trabalho de campo e formular parâmetros para, posteriormente, identificar no Brasil estruturações societárias que fossem, de um modo determinante, pautadas exclusivamente pela prisão e pela massificação do encarceramento.

Em terceiro lugar, via-se na Espanha - como no Brasil - um caso importante de massificação do encarceramento sobre o qual a reflexão sociológica acerca das suas causas, conseqüências e particularidades ainda era pouco específica - num

\footnotetext{
${ }^{50}$ A bolsa de estudos incluía passagem, pagamento do curso na UAB e ajuda de custo mensal de 1200 euros.
} 
levantamento bibliográfico preliminar, apenas Christie (2000) e Wacquant (2007) mencionavam ligeiramente a Espanha como exemplar de modulação européia de massificação do encarceramento. E finalmente, a expedição à Espanha era bem vinda por se considerar que esse país apresentava características culturais (como o catolicismo hegemônico), econômicas (como nação periférica no contexto europeu), sociais (como os fortes movimentos migratórios internos dos últimos trinta anos) e políticas (como o recente processo de redemocratização) que estabeleciam boas condições para a realização de uma comparação reflexiva e controlada.

Ao chegar ao território catalão, ainda improvisadamente instalado, parti para o levantamento de mais dados sobre o encarceramento na Espanha e Catalunha, melhor dimensionando a escala e a importância do processo de massificação do encarceramento naquela localidade. ${ }^{51}$ Inserido num contexto completamente desconhecido, sem sequer saber o nome de um bairro no qual pudesse iniciar a pesquisa empírica, tomei duas medidas imediatas. Em primeiro lugar, instalei-me a apenas uma quadra e meia da principal e mais tradicional instituição penal da Catalunha, a "Cárcel Modelo" de Barcelona - construção panóptica de 1904, localizada no bairro quadriculado do Eixample Esquerre. ${ }^{52}$ Em segundo lugar, procurei estabelecer contato com operadores e pesquisadores do tema prisional das universidades de Barcelona, pedindo-lhes que me concedessem entrevistas. Ambas as medidas se mostraram fecundas para abertura de trabalho de campo.

Por meio de um portal de anúncios na internet ${ }^{53}$ procurei um quarto para alugar na região da "Cárcel Modelo", e o encontrei num amplo apartamento habitado por cinco pessoas mais, todos jovens estrangeiros, trabalhadores e estudantes, de diversas nacionalidades, principalmente latino-americanas. ${ }^{54} \mathrm{~A}$ rotatividade dos habitantes da casa era alta, de modo que pela via da moradia precária, em curto espaço de tempo, pude desenvolver um incipiente círculo social, no qual tateava a presença de pessoas direta ou indiretamente afetadas pelo encarceramento. Em poucos meses, uma jovem (atipicamente) catalã passou a morar na casa, e conforme a fui conhecendo e lhe

\footnotetext{
${ }^{51}$ Dados que são apresentados no Capítulo 2 dessa dissertação.

${ }^{52}$ Ver Imagem 1.

${ }^{53}$ Ver: www.loquo.com

${ }^{54}$ Dividir apartamento com pessoas mais ou menos conhecidas é uma estratégia de moradia altamente difundida em Barcelona, principalmente a partir dos anos 1990, quando os preços dos aluguéis e dos imóveis aumentam muito. Para maiores informações, ver: SOTELO-BLANCO (1993).
} 
pedindo ajuda para a pesquisa, ela confessou não só ser filha de um preso, mas também ter sido concebida numa prisão de Madrid. Além de amiga, Aisa tornou-se uma de minhas informantes privilegiadas.

Sua história de vida ajudou-me a melhor realizar o campo de questões que procurava desenvolver no trabalho: as dimensões estruturantes de uma vida social pautada pelo encarceramento. $\mathrm{O}$ caso de Aisa pareceu-me especialmente revelador por ser sua experiência bastante contraditória com o que se costuma descrever para as relações familiares atingidas pela prisão de um de seus componentes. A ruptura familiar que desestrutura as condições de vida de Aisa não se deu quando seu pai foi preso, mas sim quando foi liberado. Outro aspecto importante da estrutura familiar na qual Aisa cresceu é que ela não pode ser exatamente descrita como uma "desestrutura", já que se erigia a partir da mediação constante e organizada dos órgãos da administração penitenciária, isto é, a qualidade e a quantidade das relações parentais e familiares que conformaram a primeira socialização de Aisa eram antes promovidas, concebidas e estruturadas pelo aparato de justiça estatal, do que destruídas por ele. Mais uma vez é preciso fazer a ressalva: não se atribui um valor positivo a esse tipo de socialização pautada pelo encarceramento, não se quer afirmar que, ao contrário do que dizem, a socialização de uma criança que tem o pai na prisão pode ser boa, melhor ou menos pior, se quando ela nasce, o pai já está preso; o que se quer destacar é que a análise desse caso limite e (cada vez menos) atípico ajuda a iluminar as dimensões de efeitos estruturantes da ação do aparato de justiça penal na conformação de ambientes familiares e de processos de socialização. Se essa socialização é boa ou ruim, se é melhor ou pior, se deve ser reivindicada ou denunciada, são questões que não estão em foco nesse trabalho, o que aqui interessa é descrevê-la, é mostrar como ela se dá, como ela é possível. Acredita-se que uma descrição que não se oriente por um certo "apriorismo negativista", inclusive, pode ser mais fecunda e proveitosa para a formulação da crítica.

Em paralelo aos constantes diálogos que mantinha com Aisa, uma companheira de estudos da Universidade Autônoma de Barcelona (UAB) - espanhola do País Basco, mas que morava e atuava como assistente social no Eixample há anos - colocou-me em contato com profissionais do setor de saúde e educação da "Cárcel Modelo", com os quais também pude realizar entrevistas. Aurora e Filip trabalharam por décadas no interior daquela histórica prisão, testemunhando todas as transformações recentes que 
ali tiveram lugar. Aurora é uma auxiliar de enfermagem, casada com um dos médicos da prisão ${ }^{55}$; Filip foi enfermeiro por mais de uma década e hoje exerce a função de professor na escola do presídio, também é casado com uma enfermeira que trabalha numa outra instituição prisional. Ambas as histórias de vida levaram-me a perceber outras dimensões estruturantes das instituições prisionais sobre a vida de pessoas que não necessariamente cometeram algum delito. Se é recorrente a conformação de relações afetivas nos ambientes de trabalho, ambos os relatos demonstram que nas instituições prisionais esse tipo de tendência é ainda mais forte. O compartilhamento dos problemas, preocupações, tensões e dificuldades que o ambiente prisional impõe ao trabalhador, impele a uma maior aproximação, uma vez que, segundo os informantes, é muito difícil ou quase impossível se fazer entender a alguém que nunca esteve lá dentro, e que não conhece aquela realidade. Outra questão relevante que esses relatos permitem abordar é a das transformações recentes na população prisional e no tratamento penitenciário nos últimos anos, decorrentes do aumento do encarceramento e da transformação na composição da população prisional.

É necessário ponderar que esses avanços no trabalho de campo, ao mesmo tempo em que representavam uma maior aproximação da realidade carcerária catalã, eram insuficientes para inserir-me na unidade inicial de análise que havia planejado - um bairro com elevado índice de pessoas afetadas direta e indiretamente pelo encarceramento. Aisa era nascida e criada em Terrassa, cidade satélite de Barcelona com altos índices de imigrantes andaluzes e estrangeiros, que poderia enquadrar-se nos critérios da investigação; porém, seu pai era francês de origem argelina, ficou preso na França, em Toulouse, por muitos anos, de modo que a ela foi possível manter em sigilo a condição de filha de preso. Em Terrassa, sua mãe a orientava a omitir a prisão de seu pai; em Toulouse, suas relações com o lado paterno da família e com outras crianças que visitavam a prisão eram tão efêmeras quanto um fim de semana. Aurora e Filip eram moradores dos arredores do Eixample, residiam convenientemente perto do trabalho, porém, o foco da pesquisa estava voltado para a busca de um bairro que concentrasse amigos e familiares de presos e egressos, e não funcionários de prisão. De fato, o Eixample é atualmente um bairro valorizado e central, habitado por uma classe

\footnotetext{
${ }^{55}$ A partir de sua história de vida elaborei uma reflexão sobre os desenvolvimentos recentes do sistema penitenciário catalão, ver: GODOI (2009a).
} 
média bem estabelecida e que, em linhas gerais, está mais preocupada com a desativação do presídio do que com seus habitantes.

Uma vez que o bairro no qual passei a residir não se enquadrava exatamente nos critérios da pesquisa era necessário continuar a busca. Essa era a missão principal que tinha em mente quando agendava entrevistas com especialistas sobre o tema. Aproveitava a ocasião dessas entrevistas para estabelecer algumas pontes cognitivas entre a realidade carcerária paulista e a catalã. Formulei um tipo de questionário que permitia que o próprio diálogo já fosse um exercício comparativo. Cada questão era formulada de maneira aberta para que o entrevistado pudesse falar da realidade catalã como quisesse, em seguida, para cada questão, introduzia as motivações que me faziam formular a pergunta, evocando determinados aspectos da realidade carcerária paulista para que o entrevistado comentasse semelhanças e diferenças. Pude manter esse frutífero diálogo com cinco especialistas e operadores de diferentes setores do sistema penitenciário catalão.

Angel Marzo ${ }^{56}$ é especialista em educação de adultos e por muito tempo trabalhou com projetos de alfabetização no cárcere, principalmente entre os anos 1980 e 1990, tendo publicado artigos e livros sobre o tema. ${ }^{57}$ Atualmente, atua coordenando projetos de educação de adultos no centro cívico do bairro de Besòs, periferia leste de Barcelona. Seus saberes sobre o mundo penitenciário catalão remetem a uma realidade já um tanto distante, de antes da explosão da população carcerária estrangeira, quando uma significativa parte da população prisional era de origem "gitana" e envolvida com pequenos crimes relacionados à dependência química, principalmente em heroína. Pela entrevista, pude entrever um sistema educativo prisional (comparativamente com o Brasil) muito bem estruturado. Quanto ao bairro em que atua, afirmou que existem determinados núcleos fronteiriços que podem ser considerados problemáticos, onde o aparato de justiça estatal provavelmente se faça mais presente. Porém, não lhe parecia possível conectar-me a algum desses núcleos, pois, segundo ele, como coordenador, encontrava-se relativamente distante do público atendido pelos cursos do centro cívico, e ademais acreditava que os habitantes desses núcleos ainda não estavam suficientemente sensibilizados a participar das atividades promovidas pela organização.

\footnotetext{
${ }^{56} \mathrm{O}$ nome dos especialistas não é fictício.

${ }^{57}$ Ver: MARZO (1990).
} 
Raquel Sala é técnica do setor de Educação, Cultura e Esportes da Secretaria de Serveis Penitenciaris, Rehabilitació e Justícia Juvenil (SSPRJJ) do Governo da Catalunha. Começou atuando no sistema prisional como voluntária na "Cárcel Modelo", desenvolvendo um programa de incentivo às práticas esportivas. Segundo ela, os aparelhos esportivos da prisão eram subutilizados porque as informações sobre sua disponibilidade não circulavam no interior da unidade; a divulgação dos programas, quando se dava, era feita em catalão, idioma que a maioria da população não manejava. Seu projeto de voluntária foi criar uma rede de comunicadores que articulava presos de diversas origens que dominavam minimamente o espanhol, e que se responsabilizavam em repassar as informações nos seus idiomas originais aos seus companheiros conterrâneos. O sucesso e a premiação do projeto lhe garantiram uma indicação para se profissionalizar nos quadros da administração penitenciária. Uma vez integrada à secretaria, seus contatos diretos com a população prisional diminuíram, de tal modo que, na ocasião em que conversamos, ela não podia ajudar a inserir-me em algum bairro com alta concentração de pessoas afetadas pelo encarceramento.

David Fornons é antropólogo e desenvolveu pesquisa no interior da "Cárcel Modelo" sobre os programas de tratamento da dependência química em heroína, que se dão através da administração de metadona. Segundo ele, a metadona é a principal substância farmacológica no tratamento de heroinômanos. O início de sua aplicação data da segunda metade da década de 1980, quando ainda era vista como uma substância que podia promover a cura; porém, com o desenvolvimento dos tratamentos foi se constatando que a metadona, por sua vez, também causa forte dependência, de modo que o tratamento, progressivamente, deixa de ser visto como um procedimento de cura e passa a ser visto como uma política de redução de riscos e danos. Fornons discute esse movimento e mostra como ele se dá tanto dentro quanto fora do cárcere. Manter-se sob tratamento do lado de fora da prisão passa a ser critério de progressão de pena. Todo um complexo aparato público de distribuição de metadona se instala no território urbano, anexo às instituições médicas. O auge desses programas em Barcelona se deu no início da década de 1990 e foi progressivamente perdendo centralidade conforme o perfil da criminalidade foi se alterando. Fornons apresentou-me um complexo arranjo institucional que conecta prisões e instituições médicas, porém, tampouco podia levarme a conhecer um bairro de alta concentração de afetados pelo encarceramento. 
Miriam Torrens também é antropóloga. No começo dos anos 2000, participou de um grande projeto de pesquisa que visava estudar os processos de integração sócio-laboral de mulheres que passaram pela prisão. Tratava-se de uma pesquisa comparativa entre Espanha, Reino Unido, Hungria, Alemanha, Itália e França, que está sistematizada na publicação "Women integration and prison" (CRUELLS e IGAREDA, 2005). Portanto, os seus conhecimentos sobre o universo prisional são focados na condição da mulher antes e depois do encarceramento. Torrens chamou minha atenção para uma dimensão de internacionalização dos efeitos da massificação do encarceramento na Europa. Segundo ela, um fenômeno crescente nos presídios femininos europeus é a presença das "mulas": mulheres, majoritariamente latino-americanas, condenadas por tráfico internacional de drogas e presas ainda no aeroporto, que, portanto, não mantém nenhuma relação com outro território europeu. Os efeitos (re)estruturantes de seu encarceramento se dão nos países de origem. Se essa internacionalização fica evidente no caso limite das "mulas", em alguma medida, ela também é verdadeira para uma parte significativa dos estrangeiros homens que estão presos na Europa, já que só muito excepcionalmente redes familiares inteiras migram para um mesmo bairro, de uma mesma cidade, de um mesmo país. $\mathrm{Na}$ ocasião em que conversamos, Torrens pesquisava um tema bastante diverso - vilas camponesas na Transilvânia - de modo que não podia ajudar-me a entrar num bairro em que pudesse conhecer, pelo menos, fragmentos de redes familiares pautadas pelo encarceramento.

Conforme avançava nas entrevistas com os especialistas e operadores do sistema prisional catalão ia descortinando uma série de dimensões do encarceramento na Catalunha sem exatamente dar-me conta. A frustração de não conseguir um canal de entrada para o que havia definido como unidade inicial de análise - o bairro - eclipsava as potencialidades de reflexão sobre essas múltiplas (re)estruturações que se davam dentro e fora das prisões catalãs, como a estruturação de um sistema educacional penitenciário; a estruturação de uma dinâmica rede do terceiro setor que injeta trabalhadores voluntários no interior da prisão; a estruturação de um sistema de saúde pública acoplado à prisão e voltado para o tratamento de dependentes químicos; a internacionalização dos efeitos da massificação do encarceramento na Europa, etc. Embora considerasse cada um desses processos, por si só, dignos de uma pesquisa, 
imaginava que seriam mais bem abordados a partir do momento em que pudesse verificar como eles entram em jogo num território determinado.

Um passo significativo nessa direção foi dado a partir da entrevista com o professor de Antropologia Social da Universidade de Barcelona (UB) e um dos coordenadores do Serviço de Reabilitação da SSPRJJ, Julio Zino. Zino pesquisa as instituições prisionais desde a perspectiva da análise organizacional $^{58}$, e enquanto funcionário da administração penitenciária conhece grande parte das organizações da sociedade civil que dialogam com a secretaria para a viabilização de projetos de reinserção laboral. $\mathrm{O}$ professor indicou-me uma dessas organizações para servir de ponto de partida para um trabalho de campo territorializado: a Coordinadora Contra la Marginació de Cornellà. Segundo ele, esse seria um bom início porque, além de funcionar como entidade da sociedade civil que estabelece parcerias com a SSPRJJ, a Coordinadora é uma das mais antigas e politizadas instituições civis que atuam na área penitenciária, apresentando um significativo enraizamento na comunidade local.

A Coordinadora atualmente se localiza no bairro de Sant Ildefons, na cidade satélite de Cornellà de Llobregat, a oeste de Barcelona. ${ }^{59}$ Sant Ildefons é um bairro de blocos populares, construído no fim da década de $1960^{60}$, inicialmente ocupado por uma população de operários imigrantes da Andaluzia e de Extremadura, e que, mais recentemente, vem recebendo populações de imigrantes estrangeiros, principalmente, latino-americanos e magrebinos. Ao entrar em contato com a Coordinadora, fui convidado a participar de suas assembléias ordinárias, que aconteciam todas as terçasfeiras pela noite. Acompanhando essas reuniões esperava estabelecer contatos com os moradores do bairro para agendar entrevistas e aprofundar o trabalho de campo naquele território, que parecia se enquadrar perfeitamente nos critérios estabelecidos para a investigação.

Um grande número de pessoas idosas, pais e mães de presos, compareciam às reuniões, também alguns egressos que trabalhavam na empresa de reciclagem gerida pela organização. Ainda que a presidente da entidade fosse a mãe de um preso, as assembléias eram dirigidas por um grupo de pessoas ligadas à Igreja Católica, que só

\footnotetext{
${ }^{58}$ Ver: ZINO (1995, 1997).

${ }^{59}$ Ver Imagens 2 e 3.

${ }^{60}$ Sobre a construção de Sant Ildefons, ver: GONZÁLEZ e TREMPS (1986).
} 
pela organização mantinham relações diretas com a prisão. As principais atividades da entidade eram (no começo de 2008): 1 - Grupo de Mães, que se reunia quinzenalmente e era coordenado por uma psicóloga voluntária; 2 - Programa de Assistência a Pessoas Presas e suas Famílias, que se constituía como trabalho de acompanhamento jurídico e psicológico de 34 pessoas em diferentes situações processuais (29 homens e 5 mulheres; 5 processados em liberdade, 7 cumprindo penas alternativas, 2 em liberdade sob tratamento da dependência química, 15 presos e 5 egressos); 3 -Recibaix Empresa de Inserción, que é uma empresa de reciclagem na qual trabalham egressos do sistema penitenciário e que é gerida pela entidade, em parceria com a SSPRJJ, com a prefeitura de Cornellà, com a Agència de Residus de Catalunya e com a Fundação La Caixa; 4 La Carena, que é um projeto de qualificação profissional que atendia 26 jovens com histórico de fracasso escolar.

O grande número de pessoas do bairro envolvidas nas atividades promovidas pela Coordinadora, e que tinham suas vidas diretamente afetadas pelo aparato de justiça estatal, fazia da entidade o ponto de partida ideal para a realização da pesquisa. Porém, o processo de aproximação foi lento e gradual. Num primeiro momento permitiram que participasse das atividades abertas da entidade, como as assembléias e eventos que promoviam, mas vetaram a realização de entrevistas. Por quatro meses acompanhei todas as atividades abertas da organização, aproximei-me de alguns de seus quadros, colaborei com a organização de eventos e cheguei a fazer uma apresentação sobre as condições do sistema penitenciário brasileiro. Com o passar do tempo ia criando relações de confiança que permitiram a realização de algumas entrevistas. Porém, quando já conhecia relativamente bem a dinâmica, os projetos e os participantes da Coordinadora, quando tinha efetivamente aberto a possibilidade de trabalho de campo aprofundado junto àqueles moradores de Sant Ildefons e de outras partes de Cornellà, o tempo que tinha para a investigação já tinha praticamente se esgotado; era preciso retornar ao Brasil.

Ainda que dispusesse de um grande volume de anotações de campo, de materiais recolhidos e de entrevistas feitas, que poderiam constituir um bom material de análise, ao retornar, a sensação que prevalecia era de fracasso, por não ter efetivamente podido realizar um trabalho de campo no bairro nos termos em que havia projetado. De qualquer forma, nessa espécie de busca pelo "trabalho de campo ideal", o percurso que 
havia realizado - desde os arredores de "La Modelo", passando pelos diálogos com os especialistas e operadores do sistema prisional, até o acompanhamento das atividades da Coordinadora em Sant Ildefons - permitia-me entrever a estruturação e reestruturação de um campo múltiplo de agentes, práticas e discursos, num movimento constante de experimentação, invenção, disputa que era pautado pela dinâmica de transformação do encarceramento e da realidade social. Ainda que não fosse como planejado, parecia-me possível mobilizar esses tantos achados de campo no desenvolvimento da pesquisa em São Paulo.

\section{2 - Em São Paulo}

Tendo retornado da Espanha, cabia-me desenvolver trabalho de campo num bairro periférico de São Paulo, e com o desenvolvimento da pesquisa, ponderar acerca da viabilidade de mobilizar (ou não) os materiais acumulados no velho continente. Dentre os informantes que compunham a amostra sobre a qual trabalhei durante a Iniciação Científica, procurei estabelecer contato com um deles em especial, para que fosse o meu introdutor em Guaianases, zona leste de São Paulo. Amaro ${ }^{61}$ viveu quase toda sua vida no bairro, é conhecido e conhece muita gente, teve envolvimento político em associações vicinais, e hoje coordena uma cooperativa de reciclagem já bem estabelecida na localidade. Durante quinze anos trabalhou como agente penitenciário em diversos presídios do estado de São Paulo, e sua saída do sistema se deu no contexto de expansão da facção prisional no ambiente externo à prisão: em 2001, recebeu uma ameaça de morte na porta de sua casa. ${ }^{62}$ Seu profundo conhecimento sobre o mundo prisional, seu forte enraizamento na localidade, e sua disposição em falar sem rodeios sobre os mais delicados temas faziam-me crer que ele seria um ponto de partida ideal

61 Entrevistado em 2005 por Robert Cabanes (IRD, França), com a colaboração de Daniel Hirata e Silvia Fonseca, que na época eram bolsistas da pesquisa coordenada em conjunto com Vera Telles (USP). Na ocasião pude transcrever as entrevistas e conhecer a sua história de vida. Em 2009, pela intermediação de Robert Cabanes, foi possível fazer contato com Amaro, que se dispôs a auxiliar-me na abertura do trabalho de campo em Guaianases.

${ }^{62}$ A partir da sua história de vida elaborei uma reflexão sobre o sistema prisional paulista e algumas de suas alterações recentes, ver: GODOI (2009b). 
para uma pesquisa sobre os efeitos da massificação do encarceramento num local específico.

Porém, sua condição de ex-funcionário da administração penitenciária acabou por ser mais determinante no desenvolvimento da pesquisa do que imaginava. Muitas daquelas famílias de Guaianases, que ele sabia afetadas pelo encarceramento de alguns de seus membros, também sabiam que ele havia trabalhado em presídios. Alguns egressos do bairro - um na sua própria rua - passaram por presídios em que ele trabalhara. Ainda que estivesse há mais de oito anos afastado do sistema prisional, que correntemente estabelecesse relações de vizinhança com familiares de presos e egressos, suas conversas casuais tendiam a desviar-se do tema penitenciário, porque evocavam um passado que colocava aqueles vizinhos de lados opostos dentro de um sistema "fechado", de tal modo que era difícil agendar com seus conhecidos uma entrevista sobre a prisão.

Porém, esse viés das relações, contatos e conversas não me era de todo evidente enquanto circulávamos pelo bairro. Parecia-me natural que as pessoas tivessem reserva em falar de uma questão tão delicada, fonte de tantos estigmas e preconceitos sociais, ainda mais diante de alguém de fora. Por isso insistia, seguia indo a campo, conversava com um, com outros, pensando que, ao se acostumarem com minha presença no bairro, esses bloqueios progressivamente cederiam.

Foi quando finalmente conseguimos agendar uma entrevista com a mãe de um rapaz que estava preso, que aquele viés - decorrente do passado de meu interlocutor apareceu resplandecente diante de meus olhos. Esse rapaz, que ainda estava preso, passara por grandes problemas na prisão, fora ameaçado de morte e meu interlocutor foi quem o salvou, retirando-o do pavilhão e conseguindo-lhe uma transferência para outra unidade. A mãe lhe atendia, concedendo-me uma entrevista, como uma forma velada de reconhecimento e gratidão. Foi então que entendi, que se aquele passado remoto interferia positivamente no andamento da pesquisa, seguramente também o fazia negativamente. Depois da entrevista realizada, conversamos a respeito e ele confirmou minhas suspeitas. Apenas não me havia advertido antes sobre essas dificuldades intrínsecas, por estar realmente empenhado em ajudar-me. 
A entrevista com a senhora foi bastante superficial, e só não foi mais breve porque perguntei muito sobre seu passado, sua vida profissional, sua trajetória residencial. Nina é alagoana, nascida em 1955, casou-se muito cedo com um vizinho, teve dois filhos, um rapaz e uma menina. Mudaram-se de Alagoas para o Sergipe, do Sergipe para o Maranhão, e do Maranhão para São Paulo, por volta de 1988. Em meados de 1990, na primeira viagem que fez para visitar o Maranhão, seu marido foi assassinado pelo cunhado, por conta de algumas desavenças financeiras. Nina ficou em São Paulo, na Vila Matilde, sozinha trabalhando para sustentar os dois filhos. Fez limpeza em "casa de família”, foi operária e lavadora de carros. Casou-se de novo e mudou-se para Guaianases, onde o novo marido ia construindo uma casa aos poucos. Seu filho desde cedo começou a "dar trabalho", andava com "más companhias", fumava com os meninos na rua, e aos 16 anos passou pela Fundação Estadual de Bem Estar do Menor (FEBEM). Quando ele tinha 19 anos foi preso pela primeira vez. Entre idas e vindas da prisão, ele se casou e teve um filho. Nina, já viúva pela segunda vez, hoje vive com a nora e o neto. Na mesma casa, um filho, um marido, um pai: uma só ausência. Toda a família se estrutura em torno dessa ausência, da espera de um retorno. O elo entre elas é ele, e ele está na prisão. O relato de Nina sugere importantes questões sobre uma modulação familiar promovida pela prisão, já que as duas não viveriam juntas se ele não estivesse preso. Infelizmente, não pude aprofundar o entendimento desse processo de estruturação familiar, e da dinâmica que encerrava. A nora e a filha de Nina não quiseram conceder-me entrevistas, talvez não tenham a mesma imagem daquele vizinho que me apresentou a elas.

Depois dessa entrevista fiquei duplamente convencido: 1 - núcleos familiares de um bairro periférico de São Paulo, efetivamente, podem se articular ao redor da prisão, fazendo da experiência prisional uma experiência compartilhada e familiar; e 2 Guaianases já não era - ao menos para mim - o melhor lugar para estudá-los. Teria que buscar outro campo.

Impressionava-me o como uma profissão já há muito abandonada por Amaro seguia compondo a imagem que se tinha dele no bairro. Ainda que outras identidades viessem a se sobrepor, principalmente para aqueles mais diretamente afetados pela prisão, o passado profissional de meu interlocutor, por mais remoto que fosse, seguia uma referência fundamental. Amaro não era evitado, nem perseguido no bairro, era uma 
pessoa respeitada e extremamente popular, porém havia uma certa ambigüidade na relação que estabelecia com determinadas pessoas, havia relações que eram continuamente trabalhadas, atualizadas, que podiam ruir abruptamente, numa palavra mal colocada, num rememorar inadvertido. Eu não percebia as sutilezas da relação quando era apresentado a alguém no bairro, a uma mãe de homem preso, a uma irmã, ou mesmo a um egresso, mas essas sutilezas ali estavam operando. Por maior habilidade que Amaro tivesse em tocar nos assuntos "prisão" e "pesquisador", por mais que aqueles potenciais interlocutores não se indispusessem com ele, nem comigo, as entrevistas não eram de pronto agendadas, ficavam para depois, a conversa tinha que fluir para outros assuntos, menos críticos, como se a insistência nos temas pudesse acabar prejudicando a relação.

Assim, a figura do funcionário de prisão foi ganhando relevo na pesquisa. Foi então que, paralelamente à busca de uma etnografia situada num bairro específico, procurei realizar entrevistas com outros funcionários do sistema prisional, em outros pontos da cidade, entendendo serem eles essas figuras ambíguas, também marcadas pela prisão, circulando dos dois lados das muralhas, vivenciando de um modo particular os efeitos do aumento exponencial do encarceramento, tanto dentro, quanto fora do cárcere. Ademais, conforme aprofundava o diálogo com Amaro sobre sua trajetória profissional, as trajetórias de Aurora e Filip no funcionalismo prisional da Catalunha iam ganhando novas cores, novos contrastes, de modo que ia me convencendo de que os relatos autobiográficos desses muito particulares trabalhadores podiam expressar passagens e alterações específicas, concretas e fundamentais no sistema prisional e no ambiente urbano.

Agregar elementos para aprofundar essa reflexão era a minha intenção quando propus ao meu interlocutor que me levasse conhecer seus ex-companheiros de profissão. E assim fomos de Guaianases para Santana, zona norte de São Paulo. Em Santana existia todo um complexo de instituições ligadas ao sistema penitenciário, na época em que Amaro trabalhou por lá: a Casa de Detenção, a Penitenciária do Estado, um hospital penitenciário, as sedes do sindicato e da associação dos agentes de segurança penitenciária. Atualmente, o Carandiru foi demolido, a penitenciária foi reformada e transformada em Penitenciária Feminina de Santana, a sede da Secretaria de Administração Penitenciária (SAP), que ficava no centro (Av. São João) foi para a 
região, o Centro Hospitalar do Sistema Penitenciário, o sindicato e a associação continuam ali. Fui apresentado a dois pontos desse complexo: o Sindicato dos Funcionários do Sistema Prisional do Estado de São Paulo (SIFUSPESP) e o perímetro externo da Penitenciária Feminina de Santana.

No SIFUSPESP conheci o "diretor de saúde" do sindicato, que me contou que sua principal luta atual é pelo direito à aposentadoria integral, por "acidente de trabalho", dos funcionários que foram feitos reféns nas muitas rebeliões que aconteceram no último período, e que ficaram com sequielas físicas e/ou psicológicas depois dessa experiência traumática. $\mathrm{O}$ governo oferece a esses agentes um afastamento breve e "simples", o que implica no abatimento dos abonos salariais, que representam mais de $60 \%$ do pagamento. Ou seja, o sindicato quer que o refém de rebelião seja considerado vítima de acidente de trabalho, e que se impossibilitado de voltar à função, seja assim aposentado, ganhando o direito de continuar recebendo o salário integralmente. Mais de 300 funcionários estão nessa situação, passando por fortes privações materiais. O diretor relatou-me muitos casos, colocou-me para falar com alguns "acidentados" por telefone, e assim consegui mais uma entrevista, com Raílton, que foi feito refém por 32 horas numa rebelião no Oeste Paulista e atualmente está sob tratamento psiquiátrico.

Outras dimensões da estrutura do aparato de justiça estatal também puderam ser identificadas, por observações e entrevistas realizadas a partir do perímetro externo da Penitenciária Feminina de Santana. Ali foi possível conhecer um bom número de funcionários do sistema prisional, e acompanhar o intenso movimento de "entra e sai" que caracteriza o cotidiano de uma prisão. O perímetro externo é a área que fica entre uma portaria na rua e o portão sob as muralhas, nele ficam um estacionamento e uma série de setores administrativos, incluindo a "Coordenadoria da Capital e Grande São Paulo" da SAP. Pude entrevistar mais dois antigos funcionários do sistema que hoje atuam nessa área marginal da penitenciária.

Anísio e Gonçalo entraram no sistema penitenciário ainda na década de 1960. Passaram por todo o período da ditadura militar trabalhando no interior do presídio, e ambos hoje se encontram nessa zona marginal cumprindo, mais ou menos satisfeitos, funções secundárias. Gonçalo galgou todos os cargos possíveis na Penitenciária do Estado, chegando a ser "diretor geral". No começo dos anos 2000 foi afastado pelo secretário da administração penitenciária, ficou seis anos sem posto definido, migrando de uma 
unidade a outra, de um cargo a outro. Desde meados de 2007 está lotado numa comissão administrativa. Sua sala é uma clareira aberta num galpão de arquivos, de onde sai para dar palestras de formação nos cursos da Escola da Administração Penitenciária (EAP) e para acompanhar algumas ações do recém criado Grupo de Intervenção Rápida (GIR). Segundo Gonçalo, o GIR é um grupo de elite, altamente qualificado em táticas de contenção de massas, utiliza equipamentos como balas de borracha, bombas de efeito moral e gás lacrimogêneo, escudos e cassetetes para "tomar" um raio, para fazer uma blitz, uma revista.

Anísio tomou outro rumo no sistema prisional. Estudou direito e montou um escritório de advocacia com um par de sócios para trabalhar na área de execução penal. Seus conhecimentos e prática garantiram uma trajetória ascendente tanto na área administrativa do presídio, quanto no ramo da advocacia penal. Pouco depois de a penitenciária se transformar em unidade feminina, por conflitos com a direção geral, pediu para sair da direção administrativa e ir para a portaria externa. Também já estava cansado de trabalhar com as pilhas de arquivos tanto dentro quanto fora da prisão. Atualmente, e devido à relativa tranqüilidade de sua nova posição, vem se dedicando ainda mais à advocacia, e não lhe falta serviço.

$\mathrm{Na}$ mesma proporção em que ia abrindo o leque de interlocutores no mundo dos funcionários de prisão, preocupava-me em manter o foco original da investigação, buscando uma entrada em algum outro bairro periférico, através de outros mediadores. Nesse sentido, adotei a mesma estratégia que utilizei na Catalunha, buscando no "mundo público", especialistas e operadores do sistema prisional, imaginando que eles teriam suas conexões com os grupos mais atingidos pelo aumento do encarceramento, podendo indicar-me possíveis bairros em que pudesse desenvolver a pesquisa. Contatei simultaneamente a Pastoral Carcerária, o Conselho da Comunidade da Comarca de São Paulo e a Defensoria Pública do Estado de São Paulo, e sem grandes dificuldades cheguei ao primeiro escalão de cada uma dessas instituições. ${ }^{63} \mathrm{E}$ então, um outro horizonte se descortinou, não exatamente o esperado, mas um que ampliava ainda mais o escopo de questões da pesquisa.

63 Agradeço enormemente à pesquisadora Alessandra Teixeira por facilitar-me os contatos. 
Conforme realizava entrevistas temáticas com as lideranças de cada uma dessas instituições, ia percebendo que não necessariamente, através delas, chegaria a alguma localidade periférica na qual poderia abordar, no nível mais empírico possível, os efeitos positivos e produtivos da massificação do encarceramento. Esses mediadores institucionais me remetiam mais propriamente a um outro campo de disputa política que se (re)organizava em torno da prisão e de seu incremento. E foi por isso que me interessaram especialmente: seus agentes, discursos, configurações, dilemas e disputas atuais - e mesmo suas próprias existências - incitavam-me questões sobre alguns aspectos imprevistos do encarceramento em São Paulo, falavam-me de transformações significativas do aparato prisional, e de todo um mundo social que se erigia ao redor e através da prisão, que não obstante não fosse territorializado, também extravasava a prisão para muito além de seus limites físicos e institucionais.

A Pastoral Carcerária do Brasil se organizou formalmente em $1986 .{ }^{64}$ Desde então vem prestando serviços religiosos e fiscalizando o funcionamento de unidades prisionais de todo o país. Atualmente são aproximadamente 3.000 agentes pastorais ${ }^{65}$ realizando visitas periódicas a penitenciárias e cadeias públicas, prestando assistência religiosa e jurídica, encaminhando denúncias de violações de direitos, organizando movimentos, fazendo reivindicações, etc. O Conselho da Comunidade estava previsto na LEP de 1984, mas na comarca de São Paulo só foi criado em 2005. Já a Defensoria Pública do Estado de São Paulo, que foi criada em 2006, estava prevista desde a Constituição Federal de 1988.

O Conselho da Comunidade da Comarca de São Paulo é constituído por representantes de uma miríade de entidades civis e empresariais, desde a Pastoral Carcerária até o Serviço Social da Indústria (SESI). É instituído por um juiz de execução penal e suas principais atribuições são: 1 - realizar visitas periódicas aos estabelecimentos penais da comarca; 2 - entrevistar presos; 3 - elaborar relatórios para o juiz de execução e Conselho Penitenciário; e 4 - diligenciar melhorias para a assistência ao preso. ${ }^{66}$ As visitas são agendadas junto à SAP. No interior do presídio, os conselheiros vistoriam as condições materiais das dependências e recolhem demandas dos presos. Em seguida,

64 Dado do site da pastoral, ver: http://www.carceraria.org.br/default2.asp?pg=sys/nucleo\&cat_cod=2418 (Consulta feita em maio de 2010).

65 Dado fornecido em entrevista por um agente pastoral.

66 Dado da "Portaria n. 277, de 10 de março de 2006", apresentada por um dos conselheiros entrevistados. 
elaboram um relatório e encaminham para o juiz responsável. Segundo alguns conselheiros, na maioria das vezes, não há um retorno institucional sobre os relatórios. Porém, parecia-me que mais importante do que a eficácia do Conselho era a sua efetividade, a sua existência, aquilo que permitia que sua eficácia fosse questionada. A articulação em torno da questão prisional de diversas entidades civis, algumas mais diretamente vinculadas à prisão, outras historicamente alheias aos sistemas penais, ampliava ainda mais o campo de agentes, práticas e discursos que se estruturavam, em ambiente aberto, gravitando o sistema penitenciário estadual. Parecia-me muito significativo que no momento de explosão do encarceramento, de transbordamento da prisão, de múltiplas rebeliões, que empresários, juristas, defensores dos direitos humanos, agentes pastorais, professores universitários e outros especialistas passassem a adentrar o universo prisional, a fiscalizar as unidades, a formular discursos e práticas sobre o encarceramento.

A Defensoria Pública do Estado de São Paulo é o órgão estatal responsável por prestar assistência jurídica aos cidadãos menos favorecidos em todas as áreas do direito. Até 2006, a Procuradoria do Estado destacava uma parcela de seus quadros para o exercício dessa função, numa espécie de arranjo institucional improvisado, que submetia os “defensores da sociedade" aos "defensores do Estado". Dos 400 defensores públicos existentes até 2009, metade estava na capital e metade espalhada pelo interior, apenas 12 se dedicavam à área da execução criminal e penal. Segundo um dos diretores da Defensoria, cerca de $95 \%$ da população carcerária recorre aos serviços públicos de defesa, de modo que cada defensor manipula simultaneamente uma média de 6.000 casos. Em 2006, frente aos 400 defensores, existia 1.800 promotores públicos, o que demonstra um sério desequilíbrio na capacidade de o Estado acusar e defender "a sociedade". A defensoria é uma potencial dinamizadora do fluxo carcerário, inocentando, pedindo recursos ou benefícios de progressão de pena, etc.; porém sua debilidade estrutural acaba servindo de fator de "represamento" da população penitenciária. O diretor explica que desde os "tempos da Procuradoria", o Estado mantém um convênio com a Ordem dos Advogados do Brasil (OAB) e com a FUNAP para reduzir o déficit de defesas públicas, de modo que pela via da Defensoria Pública, um enorme contingente de juristas e entidades também parecem se mobilizar em torno do encarceramento. 
Portanto, também no campo aberto junto ao que chamei de "mediadores institucionais", acabei por ser, novamente, conduzido para a identificação de tantos outros agentes, práticas e discursos que gravitam a prisão, que não podem ser descritos como efeitos do processo de massificação do encarceramento que se territorializam num determinado bairro. Não obstante, conforme conhecia integrantes da Pastoral Carcerária, do Conselho da Comunidade e da Defensoria Pública, pedia-lhes contatos com egressos e familiares de presos, com o objetivo de, assim, finalmente chegar a um bairro com alta concentração de pessoas atingidas pelo turbilhão do encarceramento. Porém, como o exercício exploratório da pesquisa foi reiteradamente demonstrando, sempre que se pensa estar indo numa direção, outro campo de possibilidades se apresenta.

Através de um dos integrantes do Conselho da Comunidade entrei em contato com Paulo, que não é egresso, nem familiar, mas um preso em regime semi-aberto. Sua própria condição se deve a essa ordem de relações estabelecidas no varejo entre pessoas diretamente afetadas pelo encarceramento e "mediadores institucionais". Numa visita a um Centro de Progressão Penitenciária (CPP), o conselheiro reconheceu Paulo entre os presos. Ambos, num passado longínquo, já haviam trabalhado num mesmo edifício. Um reformou o escritório em que o outro trabalhava. Paulo comentou com o conselheiro que já havia cumprido treze anos de uma pena de trinta, e que podia aceder ao benefício de regime semi-aberto, mas que não havia possibilidades de encontrar emprego do lado de fora das muralhas. $\mathrm{O}$ conselheiro prometeu ver o que podia fazer por ele. Conversou com um amigo empresário, dono de uma fábrica de utensílios de cozinha, e conseguiu uma vaga para Paulo na linha de produção.

Segundo o conselheiro, no CPP viviam mais de 2.000 presos, apenas cerca de 50 tinham um emprego e permissão para sair da unidade diariamente. O que era para ser generalizado naquela unidade, não era mais do que um privilégio. E Paulo, desde o começo de 2009, é um dos que, por obra do acaso, têm o privilégio de exercer o seu direito. Sai às cinco e meia da manhã do presídio, pega o trem, o metrô e deve bater o cartão às oito horas na fábrica na zona leste de São Paulo. Deixa o trabalho às seis e meia da tarde, e às oito da noite deve se apresentar novamente na unidade. Esse é o seu cotidiano de segunda a sexta-feira. Aos sábados sai também, mas não trabalha. Fez um acordo com o patrão, para que ele fizesse um documento, solicitando o seu trabalho aos sábados à direção do presídio, de modo que ele pudesse sair e visitar sua mãe, sua 
mulher e seus três filhos. No domingo, como ele não recebe visitas, passa o dia trancado na cela. Pela breve descrição do cotidiano de Paulo - que seria o mais adequado dos interlocutores a me introduzir em uma localidade de alta concentração do encarceramento - já se pode deduzir que, apesar de sua disponibilidade em conceder-me breves entrevistas antes de entrar no trabalho, apresentar-me a seus familiares e amigos, pelo menos enquanto estiver sob regime semi-aberto, não é uma possibilidade real.

Entre tentativas e logros inesperados, o tempo de trabalho de campo em São Paulo também foi passando sem que pudesse, efetivamente, inserir-me num bairro específico, para etnografar relações e vínculos sociais que se erigem a partir do encarceramento, como era previsto. Não obstante, o percurso realizado, tanto na Catalunha quanto em São Paulo, impôs uma série de questões para a investigação que precisam ser problematizadas. Se a unidade básica de análise e comparação imaginada - o bairro não pôde ser alcançada, no movimento de busca, múltiplos agentes, práticas e discursos que se estruturam ao redor e através do encarceramento se descortinaram em diferentes planos, escalas e territórios sociais, tanto em São Paulo quanto na Catalunha.

Refletir mais detidamente sobre as dificuldades encontradas no trabalho de campo, sobre as possíveis formas de se conceber e articular as informações levantadas serão o foco do próximo capítulo. 


\section{5 - Uma abordagem (im)possível}

Em toda pesquisa social a abordagem, o contato, a aproximação do pesquisador ao “objeto" é um processo complexo e delicado. Quando esse "objeto" remete a um universo social altamente estigmatizado - como é o prisional - as dificuldades se multiplicam. Contornar os tabus, os preconceitos e a desconfiança são desafios que invariavelmente se impõem ao pesquisador da prisão. Nos estudos prisionais, principalmente aqueles de caráter etnográfico e/ou que se referem ao tempo presente, os desafios metodológicos da abordagem ocupam um papel fundamental na realização e sistematização da pesquisa. Só para citar dois exemplos, em seu estudo pioneiro, Ramalho (2002) dedicou todo um excerto para apresentar sua estratégia de campo, seu percurso de entrada na Casa de Detenção de São Paulo e as implicações subseqüentes dessa entrada na qualidade dos dados recolhidos. ${ }^{67}$ Mais recentemente, Biondi (2009), também abriu seu trabalho com uma detida reflexão sobre as dificuldades em viabilizar a sua pesquisa no interior de um Centro de Detenção Provisória (CDP), envolvendo cuidados a se tomar na relação com o corpo de funcionários, e múltiplas negociações e mediações com diversos presos pertencentes ou não à facção prisional que era objeto de sua pesquisa. Portanto, pesquisar as prisões sempre exige uma difícil prática de negociação e uma apurada estratégia de abordagem, seja para abrir canais institucionais - como o fez Ramalho -, seja para abrir canais informais - como o fez Biondi - que possibilitem o bom desenvolvimento da pesquisa.

Mesmo quando o pesquisador não objetiva adentrar o espaço prisional para desenvolver sua pesquisa, quando ele se volta para “objetos" externos à prisão, mas ainda relacionados a ela, as mesmas dificuldades se desdobram. Miyashiro (2006) buscou pesquisar os impactos da prisão na socialização e na constituição da identidade de filhos de presidiários, e nessa tarefa encontrou uma infinidade de obstáculos. A autora relata as muitas dificuldades que se apresentaram, as estratégias de contornamento que adotou, e os resultados sempre insuficientes aos quais cada estratégia levou. ${ }^{68}$ Sua pesquisa -

\footnotetext{
${ }^{67}$ Ver: RAMALHO (2002) pp.32-38.

${ }^{68}$ Ver: MIYASHIRO (2006) pp.28-31.
} 
como esta - acaba por expressar essas dificuldades encontradas no decorrer do processo.

Ainda para ilustrar essa dificuldade intrínseca à pesquisa sobre a incidência da prisão em grupos e territórios que lhe são exteriores, é possível citar o trabalho que o Centro de Estudos da Metrópole (CEM) vem desenvolvendo sobre redes sociais em bairros periféricos de São Paulo há alguns anos ${ }^{69}$, e que não identificam a prisão como um campo de gravitação de um número significativo de vínculos sociais, não obstante os indícios de aumento concentrado das taxas de encarceramento nessas localidades. ${ }^{70}$ Uma proposta metodológica de pesquisa etnográfica prolongada tem o potencial de arrefecer as barreiras e tabus que se edificam ao redor do tema prisional. Feltran (2008) o demonstra em sua pesquisa em Sapopemba, zona leste de São Paulo. Em "Fronteiras de tensão: um estudo sobre política e violência nas periferias de São Paulo", o autor apresenta e analisa uma série de trajetórias e experiências, pessoais e familiares, marcadas pela atuação do aparato de justiça estatal, em especial, pela prisão. Porém, segundo ele mesmo conta, essas informações só puderam ser levantadas após anos de lenta e gradual aproximação. Portanto, agora se faz necessário ponderar que o limitado tempo disponível para a investigação, a opção por empreender pesquisa de campo em dois países bastante diferentes e as dificuldades intrínsecas à abordagem do tema prisional tornaram impossível a realização de pesquisa na imaginada unidade básica de análise: num território determinado, num bairro específico atingido por elevados índices de encarceramento.

Assim sendo, cabe indagar: qual seria então o estatuto das informações levantadas ao longo dos percursos realizados no decorrer do trabalho de campo? De um lado, as sugestões de Foucault $(1980,1987)$ sobre o dispositivo carcerário - já adiantadas na introdução desse trabalho -, e de outro, alguns aspectos da etnografia multi-situada discutidos por Marcus (1995), ajudaram-me a requalificar os materiais de pesquisa.

Esquematicamente, Marcus diferencia a etnografia multi-situada de uma etnografia "tradicional”, que se caracteriza pela observação intensa de um determinado lugar ou

\footnotetext{
${ }^{69}$ Para uma apresentação da pesquisa, ver: MARQUES et. al. (2007).

${ }^{70}$ No seminário temático de sociologia econômica, organizado pelo PPGS-USP, em 2009, tive oportunidade de indagar ao professor doutor do Departamento de Ciências Políticas da USP e coordenador do CEM, Eduardo Marques, sobre a incidência da prisão nas redes de sociabilidade que vinham sendo levantadas. O professor respondeu-me que, de toda a amostragem, apenas um informante havia abertamente afirmado ter parcela significativa da sua rede social na prisão.
} 
grupo social, e cuja análise se faz de maneira articulada à enunciação de um contexto sistêmico que é construído por outros meios, externos à observação, como grandes teorias ou dados secundários, etc. A etnografia multi-situada, segundo esse autor, é aquela que define para si um "objeto" que não poderia ser suficientemente abordado focalizando a pesquisa num único lugar, que supõe que as circunstâncias de um local só podem ser compreendidas através das conexões e articulações com processos em curso, ao mesmo tempo, em outros lugares, ou em outras dimensões da vida social. Desfazendo as clivagens entre o "mundo da vida" e o "sistema", entre o "local" e o "global”, uma nova construção do objeto etnográfico se torna possível, uma construção mais condizente com as circunstâncias históricas do mundo contemporâneo, segundo o autor.

Marcus apresenta todo um catálogo de etnografias multi-situadas que comungam um mesmo núcleo estratégico: o procedimento sistemático de seguir as conexões, as associações e as relações possíveis entre elementos observáveis em diferentes localidades. Segundo ele, alguns etnógrafos seguem pessoas; outros seguem coisas; outros seguem símbolos, discursos, metáforas; outros seguem estórias, enredos, alegorias; outros ainda seguem biografias e trajetórias de vida; e há também aqueles que seguem conflitos e suas partes. Dependendo do problema que se quer estudar, algo diferente deverá ser seguido, não existindo uma fórmula pré-definida de como realizar uma etnografia multi-situada. A definição mais geral dessa modalidade de etnografia que o autor apresenta é a seguinte:

"Multi-sited research is designed around chains, paths, threads, conjunctions, or juxtapositions of locations in which the ethnographer establishes some sort of literal, physical presence, with an explicit, posited logic of association or connection among sites that in fact defines the argument of the ethnography. Indeed, such multi-sited ethnography is a revival of a sophisticated practice of constructivism (...). Constructivists viewed the artist as an engineer whose task was to construct useful objects much like a factory worker (...).” (MARCUS, 1995, pp.105-106)

Não pretendo sugerir que realizei uma etnografia multi-situada sem o prever. Tão somente pretendo indicar que a exploração de conectores e a justaposição analítica de diferentes espaços e contextos sociais, efetivamente, pode resultar na construção de 
argumentos e objetos relevantes. Ao buscar os vasos comunicantes e os mediadores que me levassem a um bairro periférico com altos índices de encarceramento, acabei por seguir experiências pessoais e trajetórias de vida marcadas pelo aparato de justiça estatal; e através dessas experiências e estórias fui descortinando uma série de reconfigurações no sistema prisional e no mundo social que se estrutura ao seu redor, que não são necessariamente territorializados num local específico, e que tampouco são passíveis de uma descrição em termos meramente negativos.

Ao seguir pessoas que, em diferentes momentos da vida e por diferentes razões, entravam e saiam do sistema penitenciário, operando uma mediação entre esses dois mundos, pude entrever diferentes peças, processos, linhas de força e de conflito que constituem o dispositivo carcerário contemporâneo. Os relatos recolhidos eram como testemunhos da (re)estruturação de um campo múltiplo de intervenções, de práticas, de agentes, de discursos, de objetos, de poderes, de saberes e de seus constantes deslocamentos, crises, experimentações, (re)invenções, resistências e embates que conformam o que Foucault chama de dispositivo.

Parentes de presos que visitam seus entes queridos, funcionários de prisão que cotidianamente atravessam as muralhas para trabalhar, voluntários que prestam algum tipo de assistência à população prisional e que servem de "fiscais" do tratamento penitenciário, especialistas diversos, advogados e operadores do direito, são todos agentes articulados nesse amplo dispositivo prisional, e dão, cada qual, uma indicação, uma pista, um atalho para entender as reconfigurações desse campo político, social e também cognitivo, que se estrutura através e ao redor da prisão.

Entende-se que os meandros e mediadores pelos quais se desenvolveu os percursos de campo fornecem os traços de uma cartografia possível desse dispositivo. Tanto em Barcelona, quanto em São Paulo, a procura de uma via de entrada nas redes de sociabilidade de bairros periféricos especialmente afetados pelo aumento do encarceramento, mesmo se frustrada ou impossibilitada, acaba por desenhar um mapa parcial do dispositivo, uma cartografia incompleta e em aberto, mas que tem o potencial de demarcar alguns pontos e referências para o entendimento de recentes e importantes transformações do dispositivo prisional. O "fracasso" de uma proposta de trabalho de campo, na verdade, acabou por possibilitar uma exploração mais abrangente sobre o novo lugar da prisão na vida social. 
A partir desse exercício de composição cartográfica, é verdade, não serão os efeitos produtivos e territorializados do aumento do encarceramento que serão deslindados. Por outro lado, as cartografias permitirão explorar o quanto a prisão transborda e ultrapassa os seus limites institucionais, o quanto ela vai muito além do seu aparato imediato, o quanto ela produz e estrutura um mundo social multifacetado e em constante redefinição de contornos, de dinâmicas internas, de agentes, práticas e discursos. Ademais, através delas, será possível explorar algumas dimensões do dispositivo carcerário que dificilmente são consideradas nas análises e discussões sobre o sistema prisional, e que, não obstante, também entram em um novo jogo de relações, também são incessantemente redefinidas e reconfiguradas, também acompanham o processo de massificação do encarceramento e as inflexões que se observam nas práticas punitivas em cada contexto estudado.

Tal é o deslocamento que se deu no eixo da pesquisa no decorrer do seu desenvolvimento, e que explica a forma e conteúdo dos próximos capítulos. 


\section{6 - Uma cartografia do dispositivo carcerário catalão}

A cidade de Barcelona é conhecida no Brasil por abrigar uma das mais importantes e caras equipes do futebol internacional. Se ser jogador de futebol é um sonho recorrente na infância brasileira, jogar no F. C. Barcelona - todos hão de concordar - é o ápice do sucesso, a realização do sonho, aquilo que só (poucos) jogadores extraordinários alcançam. Ainda, a imagem da cidade de Barcelona, para os brasileiros, também é associada a um dos mais lembrados jogos olímpicos da era moderna: Barcelona-92. Em tempos de preparação para Olimpíadas de 2016, no Rio de Janeiro, o "modelo Barcelona" é recorrentemente evocado para exemplificar o potencial transformador e modernizador da realização dos jogos olímpicos na cidade que os sedia. ${ }^{71}$ De fato, como foi possível averiguar no decorrer do ano vivido em Barcelona, o futebol é uma das expressões culturais mais encarniçadas e mobilizadoras da Catalunha ${ }^{72}$, e resquícios das Olimpíadas de 1992 são visíveis por toda a cidade, em edifícios residenciais, no sistema de transporte, no parque esportivo, etc.

Outra referência do mundo catalão relativamente bem conhecida no Brasil é a conflituosa relação que essa cultura guarda com o restante do Estado espanhol, principalmente com o governo central (Real) de Madrid. De fato, ainda que Barcelona seja uma cidade bastante cosmopolita, podia perceber uma espécie de indisposição com o "espanhol" pairando no ar, perceptível nas bandeiras da Catalunha penduradas nas sacadas, nas diversas manifestações, organizações, partidos e militantes nacionalistas (de direita e de esquerda) que fui conhecendo nas ruas e jornais do dia-a-dia. O "problema catalão" aparece de diversas maneiras e por toda parte, e como afirma Montalban: "ha hecho correr ríos de tinta y sangre" (in FIGUERUELO, 1970, p.15).

\footnotetext{
${ }^{71}$ Ver, por exemplo, as seguintes matérias jornalísticas: REDAÇÃO. “Cabral: legado de Barcelona-92 é lição para o Rio." Agência Rio de Notícias, 03 de fev. de 2010 [on line] disponível na Internet via: http://agenciario.com.br/materia.asp?cod=74023\&codEdit=41\&evento=1; e AGÊNCIA EFE. "Paes se inspira no exemplo de Barcelona-92." Lancenet, 05 de fev. de 2010 [on line] disponível na internet via: http://www.lancenet.com.br/noticias/10-02-05/695921.stm (Consulta feita em maio de 2010).

${ }^{72}$ A relação do povo catalão com o principal time de sua capital é tão forte que se diz que o Camp Nou estádio do "Barça" - foi durante as décadas do franquismo, o único território da cidade onde se podia falar catalão publicamente.
} 
Porém, na presente cartografia, a imagem de Barcelona que se pretende esboçar passa tão longe do palco de espetáculos futebolísticos, da bem sucedida sede das Olimpíadas, quanto da discussão e análise do "problema catalão". Uma outra Barcelona aqui será dada a conhecer, nem a comumente imaginada pelos brasileiros, nem a reivindicada por muitos catalães legitimamente orgulhosos de sua cultura. Trata-se de uma visão conformada pelo olhar de um pesquisador latino-americano que olha para uma porção da Europa (mais do que para a capital da Catalunha), especialmente interessado nas características e no funcionamento de um desconhecido sistema punitivo, e que transitou por oito meses nas sendas do dispositivo carcerário, na busca por um bairro em que se sentisse alguns dos efeitos do aumento do encarceramento.

\section{1 - Marco Zero}

O ponto de partida dessa cartografia é a "Cárcel Modelo" de Barcelona, ponto de referência no qual me apoiei na busca por hospedagem. ${ }^{73} \mathrm{O}$ complexo panóptico construído em 1904 abriga hoje o Centre Penitenciari d'Homes de Barcelona e o Centre Penitenciari Obert 1 de Barcelona - que juntos abrigam mais de 2.100 presos, concentrando cerca de $20 \%$ de toda a população carcerária da Catalunha. ${ }^{74}$ Trata-se de todo um quarteirão delimitado pelas ruas Entença (frente), Rosselló (lado esquerdo), Provença (lado direito) e Nicaragua (fundo). O primeiro ocupa todos os edifícios radiais e o pavilhão de fundo; o segundo ocupa um pequeno edifício na esquina das ruas Entença e Rosselló, ao lado esquerdo do pavilhão fronteiriço.

A história da "Cárcel Modelo" ${ }^{75}$ se confunde com a própria história do sistema penitenciário ocidental, do sistema penitenciário espanhol e com a história urbanística de Barcelona. Antes de sua fundação, a cidade contava com prisões de forte caráter religioso, uma para mulheres "desajustadas" e prostitutas - a Cárcel de Dones ou "La Galera"- e uma destinada a todos os outros "desajustados", nos moldes dos Hôpitaux

\footnotetext{
${ }_{73}^{73}$ Conforme relatado no Capítulo 4 dessa dissertação.

${ }_{74}^{74}$ Segundo funcionário da unidade, em entrevista concedida em 2007.

${ }^{75}$ Para maiores informações, ver: PRODUÇÃO COLETIVA (2004).
} 
Generaux descritos por Foucault em "A História da Loucura" (1978) e "Vigiar e Punir" (1996), albergando desde doentes mentais, crianças e anciãos abandonados, até vagabundos e criminosos - essa a Casa Municipal de Corrección, também conhecida como "Cárcel Nacional", "Presó Vella” ou "Cárcel de Amalia".

Ambas as prisões corporificavam toda a vileza punitiva que era alvo dos reformadores penais, no final do século XIX. No contexto da Exposição Universal de 1888, sediada em Barcelona, foi lançada a pedra fundamental da nova "Cárcel Modelo", projetada para funcionar como prisão celular de isolamento quase absoluto; e também se iniciaram as obras de um abrigo para menores, conhecido como "Asilo Durán". Esses projetos bem se encaixavam tanto no esforço de racionalização do sistema punitivo barcelonês, como nos esforços de modernização da própria cidade. Barcelona se destacava como potência industrial da Espanha e para se ter uma idéia da atmosfera explosiva que motivava sub-repticiamente os esforços de modernização penal, vale destacar que no mesmo ano de 1888, no decorrer da grande exposição, o sindicato Unión General de los Trabajadores (UGT) foi fundado, organizando diversas greves e manifestações.

Não seria demasiado afirmar que a inauguração de "La Modelo", em 1904, se insere perfeitamente no processo de emergência e consolidação do poder disciplinar, nos mesmos termos descritos por Foucault em "Vigiar e Punir". Um contexto de avanço industrial, de proliferação de mercadorias circulantes, de aumento populacional principalmente das classes perigosas -, as ameaças de sedição, etc., que vão criando o ambiente e promovendo as condições para uma necessidade de expansão dos aparatos de punição e de vigilância. O planejamento e a construção dos arredores da prisão também poderiam ser vistos como expressão desse processo, já que o bairro do Eixample é quase inteiramente projetado em termos disciplinares: quadriculado, com vias paralelas e diagonais que racionalizam a circulação e potencializam a vigilância. ${ }^{76}$

Porém, também é importante ressaltar que a construção do bairro e da prisão sucede a demolição da muralha que circundava a cidade, o que expressaria de uma maneira muito concreta a passagem de um período de preeminência do poder soberano - voltado para a defesa do território - para um período no qual ganha preeminência uma certa

\footnotetext{
${ }^{76}$ Sobre o longo processo de planejamento e construção do Eixample ver: CASTELLVÍ (2002).
} 
composição entre poder governamental - voltado para a gestão de fluxos de bens e populações - e poder disciplinar - voltado para o controle dos corpos. Foucault discute essa passagem e essa composição de dispositivos de poder em "Segurança, Território e População" (2006). Segundo o autor, a construção das instituições disciplinares fechadas funcionava como contrapartida da abertura da cidade, que era promovida pela emergência de uma nova arte de governar o urbano, as pessoas e as riquezas. Ou seja, os esforços de disciplinarização dos corpos se compunham com outros de gestão governamental dos fluxos de riquezas e populações. Desde essa perspectiva, o Eixample, além de expressão disciplinar seria também governamentalizado, já que além da vigilância, objetivava uma mais eficiente circulação e conexão com outros territórios.

Ampliando ainda mais o foco de observação, a poucas quadras da prisão - seguindo pela Rosselló - também em 1904, foi fundada a Escola Industrial, e algumas quadras adiante, em 1906, foi inaugurado o Hospital Clinic - instituições marcadamente disciplinares que também visavam a modernização e racionalização da cidade de Barcelona, para colocá-la no mesmo nível civilizatório das grandes capitais européias. Portanto, uma escola, um hospital e uma prisão formam uma tríade disciplinar retilínea no interior do bairro: uma conformação espacial tão evidente do projeto de sociedade disciplinar-governamentalizada dificilmente se encontrará em outra cidade ocidental. ${ }^{77}$

Não é objetivo e nem seria possível nesse trabalho reconstituir pormenorizadamente todo o percurso e todas as alterações importantes que aplacaram a mais importante instituição penal da Catalunha. Com os dados disponíveis, pretende-se tão somente indicar algumas alterações que se deram no dispositivo carcerário que abarca e atravessa essa instituição prisional nas últimas três décadas. Pelos relatos recolhidos, é possível descrever um ambiente prisional e urbano bastante distante daquele projeto civilizatório do começo do século XX: as práticas do tratamento penitenciário distando sobremaneira do que foi projetado no início do funcionamento da prisão moderna; as entidades, organizações civis e grupos profissionais que incidem no funcionamento das instituições punitivas muito pouco se parecendo com aquelas que fomentaram a modernização do aparato punitivo barcelonês, e a população que passa por essas instituições punitivas só se assemelhando com aquelas do começo do século na precariedade das condições de vida.

\footnotetext{
${ }^{77}$ Ver Imagem 4.
} 
No entanto, mais do que precisar essas distâncias seculares, o que entra no foco dessa cartografia é o registro de distâncias e alterações no dispositivo - aspectos de seu jogo, de suas redefinições estratégicas e funcionais, de suas disputas - que se desenvolveram nesses últimos trinta anos. Ou seja, a problematização alcança apenas o que pôde ser visto, vivido e relatado pelos agentes que aturam e se (trans)formaram nesse dispositivo e que cruzaram os seus percursos com o dessa investigação. De todo modo, como deverá ficar evidente, entre o começo da década de 1980 e o final dos anos 2000, as reconfigurações desse campo multifacetado de práticas, discursos, objetos e saberes que se estrutura ao redor da prisão são de extrema relevância e oferecem importantes elementos para a reflexão sobre a atualidade e as possibilidades do dispositivo carcerário.

Desde já, adianto algumas (macro)demarcações que indicam os sentidos das mais estruturantes reconfigurações do dispositivo cartografado, considerando seu jogo de relações com outros campos da vida social. O início da década de 1980 é marcado pelo processo de redemocratização do estado espanhol; pela crise da cidade industrial; pela explosão do mercado de heroína; e pelas derradeiras etapas de um forte processo de migração interna e de expansão metropolitana, através da construção de polígonos residenciais nas cidades satélites de Barcelona. Já a década de 2000 é marcada por um novo jogo político entre governo central e comunidade autônoma, no que diz respeito a políticas criminais e administração penitenciária; pela conversão econômica da cidade de Barcelona em território turístico e de serviços; pela redução do mercado de heroína e correspondente diversificação do mercado das drogas; e pela intensificação da imigração internacional e conseqüente transformação das populações residentes de bairros periféricos, cidades satélites e prisões.

Agora, a partir desse ponto, tomo como fio condutor da exposição, as trajetórias de personagens que vivenciaram o dispositivo e suas alterações, entendendo que seus percursos traçam as linhas de força, os impasses, os deslocamentos, estruturações e reestruturações que assentam as trilhas dessas (macro)demarcações acima adiantadas. 


\section{2 - Manola}

No fim de 1981, Manola entra pela primeira vez na "Cárcel Modelo". Seu filho mais velho, então com 18 anos, fora preso meses antes por roubar um supermercado. 1981 havia sido um ano muito difícil para essa trabalhadora doméstica; perdera seu marido operário num ataque do coração, e descobrira uma seringa de aplicar heroína entre as meias de seu filho. O sofrimento que sentia ao ouvir o abrir e fechar das pesadas portas gradeadas não era mais que uma extensão de todo o amargor experimentado no decorrer do ano.

Manola nasceu em Tarifa, extremo sul da Andaluzia, em 1940. Seu pai era pescador e sua mãe trabalhava numa fábrica de peixes enlatados. Todos os seus seis irmãos trabalhavam no ramo da pescaria, ou no barco, ou no mercado ou numa das fábricas de enlatados. Ela era a única que, desde muito cedo, trabalhava num outro segmento. Com oito anos começou a trabalhar numa padaria, carimbando os cartões de racionamento de alimentos, instituídos por Franco logo após vencer a Guerra Civil. ${ }^{78}$ Por dez anos trabalhou na mesma padaria, depois passou cinco anos trabalhando numa mesma casa de família, até que em 1963 se casou com um vendedor de peixes e deixou de trabalhar. Teve seus três filhos num lapso de cinco anos. A vida era dura, mas pelo emprego de seu marido, ao menos comida nunca lhe faltava. Já seus pais e seus irmãos não tinham a mesma sorte, as dificuldades eram imensas. Depois de sobreviver a um naufrágio, seu pai já não queria pescar. A solução que encontraram foi a mais comum naquela época: a migração. No final da década de 1960, sua família pouco a pouco foi se instalando numa cidade industrial vizinha a Barcelona, Cornellà de Llobregat, onde todos muito rapidamente encontraram empregos na indústria e no comércio. Sua mãe lhe incentivava a também migrar para a Catalunha, fato que acabou se concretizando no ano de 1971. Seu marido, de comerciante tornou-se operário da indústria automobilística, e Manola passou a trabalhar numa casa de família no centro de Barcelona.

A década de 1970 foi vivida como uma década de prosperidade por toda a família, os irmãos de Manola foram se casando e a casa onde todos viviam foi ficando mais

\footnotetext{
${ }^{78}$ Sobre a política de racionamento do primeiro período do franquismo, ver: SÁNCHEZ (2000).
} 
espaçosa. A morte de Franco em 1975, e os auspícios de democratização propagados pelo novo Rei de Espanha, Don Juan Carlos de Borbón, e pelo ascenso do movimento operário, estudantil, de bairro, e de anistia pareciam arejar ainda mais o ambiente na casa de Manola. ${ }^{79}$ Manola acompanhava o processo político de abertura pelo jornal, e torcia para que tudo corresse bem. Para ela, de fato, as coisas iam bem até aquele fatídico ano de 1981.

A partir de então Manola reestruturou seu cotidiano, dividindo o tempo entre trabalho, os filhos mais novos e os vasos comunicantes que a ligavam ao filho na prisão. Com o tempo foi se interando das diversas possibilidades de contato que o sistema lhe proporcionava: 1 - conversas de vinte minutos através de um anteparo de vidro; 2 visitas de três horas com contato corporal aos finais de semana; 3 - cartas; 4 telefonemas periódicos que recebia do filho com hora marcada; 5 - encaminhamento de roupas, alimentos e objetos pessoais através dos serviços de "paquetería". 80 Esse conjunto de eventos colocavam a sua vida e a de seu filho num mesmo plano de temporalidade, que era, efetivamente, determinado pela instituição penitenciária. Nem ela, nem ele tinham autonomia para agendar os telefonemas ou as visitas sem contato físico (que podiam ocorrer durante a semana) nos horários mais adequados, quando ela não estivesse trabalhando. Não obstante, Manola aproveitava o mais possível cada possibilidade que os vasos comunicantes lhe proporcionavam, pois assim podia manterse minimamente informada da saúde e da vida do filho.

Nas primeiras visitas a "La Modelo", encontrava o seu filho muito mal, magro, com aspecto de doente, nervoso e inquieto; não estava certa, mas intuía que ele, mesmo preso, seguia usando heroína. Tinha a impressão de que ali estavam todos loucos; na fila se comercializavam vagas; no pátio, ambulâncias ficavam permanentemente a postos, e não raramente as via sair em disparada, removendo um preso assassinado, morto por overdose, de AIDS, ou auto-lesionado ${ }^{81}$ - as mães e esposas desesperadamente acudiam para tentar descobrir se ali estaria seu filho ou marido. No que diz respeito às práticas de tratamento penitenciário, Manola afirma que, àquela altura, não havia nenhum tipo de

\footnotetext{
${ }^{79}$ Sobre o processo de redemocratização da Espanha, ver: TUSSEL (1999).

${ }^{80}$ Caberia acrescentar o vaso comunicante da visita íntima, possibilidade aberta a cônjuges e pessoas que comprovam relação afetiva estável com o preso.

${ }^{81}$ A prática da auto-lesão era significativa e recorrente, para um relato autobiográfico que aborda as causas e significados dessa prática nas prisões catalãs, no começo dos anos 1980, ver: ZAMORO (2005).
} 
programa específico destinado aos dependentes químicos, e que as surras e maus tratos davam o tom do tratamento dispensado aos presos.

\section{3 - (Re)estruturações}

Essa história de Manola poderia ser muito bem enunciada como mais um exemplar do unívoco processo de desestruturação familiar: a morte prematura do chefe de família, a droga, o crime, a prisão, a violência e a ruptura dos laços familiares. Porém, seguindo o seu percurso a partir da prisão de seu filho, é possível entrever processos de (re)estruturação, por um lado, da vida social de Manola - que destoam da imagem catastrófica de uma família destruída -; e por outro lado, do que poderia ser visto como a própria vida do dispositivo prisional catalão.

Desde a prisão de seu filho mais velho, Manola redobrou os cuidados e a vigilância sobre os seus dois filhos mais novos, de modo que os laços entre eles se fortaleceram ao invés de se debilitarem. Os dois filhos menores a apoiavam, e com eles, ela passou a conversar de uma maneira mais aberta e franca sobre todo e qualquer tema considerado delicado, como sexo, drogas, dinheiro, etc. Para fundamentar suas orientações sobre questões que pouco conhecia, e para melhor lidar com a situação do filho preso, ela se movia em busca de informações. Passou a freqüentar palestras sobre a AIDS, o crime e a droga promovidas por diversas organizações, como a Igreja Católica, associações de moradores, polícia, prefeitura, etc.

Através dessas palestras, Manola conheceu um grupo de mulheres que viviam a mesma situação e tinham as mesmas angústias e necessidades; com o tempo, combinavam e iam juntas a esses eventos e à prisão. Numa determinada palestra, foram convidadas a participar de umas reuniões que ocorriam no "Ateneo", uma fábrica ocupada nos arredores de Cornellà. A reunião era convocada por um grupo de egressos, professores e militantes do movimento "Okupa" ${ }^{82}$, e tinha o objetivo de desenvolver ações de ajuda e assistência aos presos e egressos daquela região. De pronto, Manola se identificou com

\footnotetext{
${ }^{82}$ Sobre o movimento "Okupa", ver: MARTÍNEZ (2003) e COSTA (2004).
} 
eles e passou a ser uma freqüentadora assídua das reuniões que ocorriam todas as terçasfeiras pela noite.

O "Ateneo" agregava artistas, militantes dos movimentos de moradia, e com a consolidação do grupo de egressos, familiares de presos, alguns militantes pró-anistia e outros abolicionistas penais, passou também a compor o campo que se estrutura ao redor da prisão e supera os seus limites jurídico-institucionais. Por meio das reuniões que ali tinham lugar, Manola entrou em contato com outras dimensões do dispositivo carcerário, podendo desenvolver uma visão mais abrangente sobre o sistema prisional espanhol, informando-se e discutindo questões prementes que se impunham em diversas localidades. O poder de articulação daquele reduzido coletivo era bastante significativo, e Manola provou ser peça chave de muitas das articulações. Em pouco tempo, ela ajudou a estruturar um grupo de mães de presos (que, em separado, compartilhavam experiências e discutiam a situação das prisões), uma empresa informal de reciclagem (para oferecer oportunidade de trabalho para os egressos e levantar fundos para o coletivo), manifestações em Madrid e Barcelona (para reivindicar melhorias no sistema penitenciário), articulações com os setores mais progressistas da Igreja Católica (para fortalecer a legitimidade do movimento), entre outras ações. Ou seja, a partir da prisão de seu filho, Manola se inseriu num agitado ambiente político que se organizava ao redor do problema penitenciário, que pressionava, propunha, contrapunha-se e reagia aos deslocamentos operantes no dispositivo carcerário. Eis uma muito importante estruturação societária que compunha, àquela altura, o campo disperso do dispositivo.

Mas, caberia perguntar: não seria essa uma experiência isolada? Seria mesmo todo um campo político-social que se erige a partir da prisão ou se trataria de estruturações societárias por demais dispersas e sem muita importância política? Alguns precedentes históricos podem ajudar a aclarar essa questão e bem situar a etapa de desenvolvimento dessas (re)estruturações do dispositivo, na primeira metade da década de 1980. Para tanto, é possível recorrer ao artigo de Rubio (2005), intitulado "La Revuelta de los Comunes: una primera aproximación al movimiento de presos sociales durante la transición". Nesse artigo, o autor apresenta a trajetória da Coordinadora de Presos en Lucha (COPEL), entre os anos de 1976 e 1979, no auge do movimento por anistia, em tempos de redemocratização do país. A COPEL nasceu em 1977, em "Carabanchel" mais emblemática prisão do período franquista, situada em Madrid - e rapidamente se 
espalhou pelas mais importantes instituições carcerárias da Espanha, entre elas, obviamente, "La Modelo" barcelonesa. O movimento reivindicava a extensão das anistias e indultos aos presos "sociais" (comuns), melhorias no tratamento penitenciário e uma ampla reforma em todo o sistema penal. Dentro das prisões, organizavam-se por assembléias, realizavam rebeliões, articulavam greves de fome e auto-lesões coletivas estes últimos expedientes como táticas para colapsar os serviços médicos da unidade, assim demonstrando sua precariedade. Do lado de fora, contavam com amplo apoio de Coordinadoras compostas por familiares, por defensores dos direitos humanos, intelectuais, sindicalistas, e militantes socialistas e anarquistas - entre elas, é possível citar a Asociación de Familiares y Amigos de Presos y Ex Presos (AFAPE); a Asociación para el Estudio de los Problemas de los Presos (AEPPE), e os Comités de Apoyo a COPEL de Madrid, Barcelona, Bilbao e Valencia.

Os anos de 1977 e 1978 foram marcados por forte mobilização popular em torno da questão penitenciária, dentro e fora das prisões, de modo que anistias e indultos parciais foram concedidos pelo Rei, e a reforma penitenciária - ainda que bastante criticada e insuficiente - foi a primeira a ser realizada no período democrático. ${ }^{83}$ Segundo Rubio, no interior das prisões, o movimento da COPEL começou a se enfraquecer em 1979: 1 com o isolamento das mais eminentes lideranças num presídio de Santander; 2 - com a redução da perspectiva de indulto estendido depois da reforma; 3 - com a diversificação das práticas da COPEL em diferentes unidades, sem respeitar uma linha política clara; e 4 - com a introdução do comércio de heroína no interior das prisões e com o desenvolvimento de quadrilhas de traficantes que ou controlavam ou inviabilizavam as assembléias nos presídios.

Do lado de fora, as associações tenderam a privilegiar outras pautas, apoiando outros movimentos, que apresentavam maiores possibilidades de avanço. Portanto, o momento em que o grupo de Cornellà começou a se organizar, e que Manola começou a atuar, pode ser considerado como uma fase de refluxo e reestruturação de um campo que havia emergido com força poucos anos antes, atravessando todo o dispositivo carcerário espanhol.

\footnotetext{
${ }^{83}$ Para uma reflexão sobre a reforma penitenciária, feita por Carlos García Valdés - pesquisador, idealizador e realizador da reforma - enquanto Diretor Geral de Instituições Penitenciárias do governo de transição, ver: VALDÉS (1981).
} 


\section{4 - Rotinizações}

No final de 1986, tendo cumprido cinco anos e três meses de uma pena de seis, seu filho foi posto em liberdade. Logo, Manola percebeu que ele seguia usando heroína, e já mais bem informada e com um amplo leque de contatos conquistados no movimento social, conseguiu uma internação para ele numa conceituada instituição de tratamento. Depois de alguns meses de internamento, os médicos instruíram Manola a afastar seu filho de Cornellà por algum tempo, para seguir tomando medicação e ficar distante da oferta da droga. Manola então enviou seu filho para Tarifa, onde seus pais, já aposentados, haviam voltado a viver. O que Manola não sabia é que seu filho tinha um julgamento pendente, acusado de cúmplice de homicídio. Um preso fora assassinado no interior da cela que ocupava na "Cárcel Modelo"; ainda que não tivessem envolvimento no caso, pela recusa em apontar o autor do crime, todos os residentes da cela foram indiciados. $\mathrm{O}$ julgamento só foi marcado quando ele já estava em Tarifa. Procurada pela polícia e desinformada da acusação, Manola comunicou aos policiais que seu filho estava em Tarifa, sob tratamento, e que logo voltaria à Catalunha. Os policiais repassaram a informação para a polícia da Andaluzia, que o deteve ali mesmo. Depois de nove meses preso no sul do país, em 1988, ele foi transferido de volta para "La Modelo", e condenado a mais sete anos de prisão.

Essa segunda prisão de seu filho foi um duro golpe na vida de Manola. Ela se sentia culpada por ter falado a verdade aos policiais, por ter sido inocente e desinformada. Uma questão judiciária ainda agravou a situação. Pouco tempo depois de formalizada a acusação, o autor do crime assumiu o delito e todos os presos incluídos no processo entraram com recursos e acabaram absolvidos. Porém, quando estava na rua, novamente usando drogas, seu filho perdeu certos papéis e prazos para dar entrada no mesmo recurso. Resultado: da mesma acusação de cúmplice de homicídio, ele seria o único a cumprir pena. Manola, então, se desestruturou e se reestruturou, partindo para uma luta judiciária cotidiana, tentando reverter aquele equívoco.

Nesse período, ela percorreu os (des)caminhos do aparato judiciário catalão, consultou diversos advogados, fez reuniões com juízes, pressionou burocratas e arquivistas, ficou 
conhecida nos fóruns e tribunais. Porém, uma vez condenado, já não era possível conseguir a absolvição. Mesmo assim, Manola constantemente ia à administração penitenciária e mesmo à prisão explicar a situação a quem quer que fosse - assistentes sociais, funcionários administrativos, diretores de segurança e até ao diretor geral da prisão -, reivindicando a aceleração da concessão dos benefícios de progressão de pena, de modo que ele saísse o mais rápido possível. Só em 1994, um ano antes do cumprimento integral da pena, ela atingiu esse objetivo. Nesse segundo período de prisão, o filho de Manola já deixara de consumir heroína, passando por tratamento a base de fármaco opiáceo chamado metadona, administrado tanto em "La Modelo", como em Can Brians, onde terminou de cumprir a pena.

A essa altura, as reuniões que Manola freqüentava às terças-feiras já se chamavam Asambleas Generales de la Coordinadora Contra la Marginació de Cornellă ${ }^{84}$; a empresa de reciclagem já estava formalizada com o nome de Recibaix - onde seu filho chegou a trabalhar por alguns meses entre 1994 e 1995 -; o grupo de mães já contava com o apoio de uma psicóloga; e já existia um programa formalizado de acompanhamento de presos da região em diferentes unidades prisionais da Catalunha.

Muito aos poucos, as rotinas iam mudando na prisão, no coletivo que freqüentava e na vida privada de Manola. Sua mãe faleceu e ela trouxe seu pai para viver com ela; os cuidados que aquele senhor de idade exigia fizeram com que ela deixasse a atuação na Coordinadora. Isso no mesmo período em que seu filho era preso novamente, dessa vez por tráfico de heroína e metadona. Então, Manola já aceitava e se acostumava a ter um filho na prisão - aquela situação havia se tornado também uma rotina.

\section{5 - Aurora}

É exatamente no contexto de desenvolvimento de uma abordagem médica ao problema da heroína nas ruas e prisões de Barcelona que Aurora é introduzida no sistema penitenciário. Ela é auxiliar de enfermagem em prisões desde 1987, e atualmente

\footnotetext{
${ }^{84}$ As mesmas que em 2008 eu pude acompanhar.
} 
trabalha no setor psiquiátrico de "La Modelo". Nascida em 1965, em Barcelona, é filha de um catalão com uma imigrante murciana. Fez estudos técnicos de secretariado e auxiliar de enfermagem, trabalhou como secretária e fazia substituições em hospitais até ser contratada pela administração penitenciária. Em 1986, Barcelona foi nomeada a cidade sede das Olimpíadas de 1992, e muito provavelmente por isso, as autoridades decidiram por intensificar e diversificar as ações contra a "epidemia" da heroína, adotando o modelo estadunidense de tratamento a base de metadona. ${ }^{85}$ Para que o tratamento fosse eficiente, fazia-se necessário a sua implementação nas prisões, foco privilegiado da "doença", e para tanto, era necessário dispor de quadros técnicos capazes de operar o programa.

O primeiro posto de trabalho de Aurora no sistema penitenciário foi na unidade de Tarragona, no sul da Catalunha. Seu primeiro serviço prestado no interior da prisão foi realizar uma sutura num preso que havia se auto-lesionado, cortando as veias do braço. Segundo Aurora, já àquela altura, a prática da auto-lesão, apesar de recorrente, era desprovida das características de tática de protesto, que marcaram o período de atuação da COPEL. Para ela, os presos se auto-lesionavam de maneira utilitária, por demandas particulares, como por maiores doses de metadona, por transferência a outra unidade, ou simplesmente para passar um período na enfermaria do presídio, onde o tratamento era mais ameno. Além de costurar os cortes que os presos faziam em si ou nos outros, a principal tarefa de Aurora era preparar e distribuir as doses de metadona, que, segundo ela, eram administradas diariamente a mais de $75 \%$ da população do presídio.

Entre 1989 e 1990, novas prisões foram inauguradas na Catalunha, como a de Can Brians - onde o filho de Manola terminou de cumprir sua segunda pena - e a de Quatre Camins, em Granollers (a 30 quilômetros de Barcelona), - onde Aurora foi trabalhar logo que inaugurada a unidade. Essas novas unidades prisionais já não reproduziam a arquitetura panóptica de "La Modelo"; eram instituições modulares, que seguiam uma nova proposta arquitetônica de vigilância, inspirada no modelo das supermax dos Estados Unidos.

\footnotetext{
${ }^{85}$ Para uma análise crítica dos programas de metadona nos Estados Unidos, ver: BOURGOIS (2000). Para uma avaliação das políticas de tratamento a base de metadona em Barcelona, ver: MUNS (2003). Para uma avaliação epidemiológica do impacto do tratamento de metadona numa prisão catalã, ver: ARROYO et. al. (2000).
} 
Essa ordem de alteração arquitetônica é considerada um importante indício de deslocamento no dispositivo carcerário. Chantraine (2006) sustenta que o advento da prisão modular é a expressão arquitetônica da aurora de uma era penitenciária póscorrecionalista, pós-disciplinar - quando o dispositivo carcerário passa a ser regido por outros objetivos estratégicos.

No caso da Catalunha, as indicações de Chantraine fazem bastante sentido. Entre o final dos anos 1980 e começo dos 1990, pelo que se percebe através dos relatos de Aurora, é possível afirmar que um novo paradigma punitivo - ou uma reconfiguração do dispositivo carcerário - se desenvolve na Catalunha. O dispositivo se volta para a urgência da "doença epidêmica" da heroína, agregando novos operadores, reformulando suas táticas de atuação por um viés médico-farmacológico, e reprojetando a correção disciplinar em termos de cura pela metadona. De modo correlato, uma nova arquitetura prisional emerge e novas prisões são construídas. De um lado, a estruturação de um aparato médico-hospitalar de combate à heroína - então vista como a grande causa da criminalidade, e por extensão, a grande inimiga das vindouras Olimpíadas -; de outro, uma política de expansão de vagas, com a construção de novas unidades modulares no interior da Catalunha, que além de corporificarem uma nova proposta de vigilância e tratamento, apresentavam a vantagem de poderem ser ampliadas segundo as necessidades, através da agregação de novos módulos. ${ }^{86}$

\section{6 - (Des)ajustes}

Se no começo dos anos 1990 o tratamento pela metadona admitia um horizonte de cura, muito rapidamente esse horizonte se fechou. A cura da dependência química deixou de ser objetivo do programa e outros objetivos se colocaram para justificar a manutenção dos tratamentos - principalmente o controle da epidemia de AIDS, uma vez que a metadona é ingerida oralmente, dispensando a manipulação de seringas. A metadona também é um derivado do ópio, que atua reduzindo a forte crise de abstinência da

\footnotetext{
${ }^{86} \mathrm{O}$ que de fato vai acontecer no decorrer dos anos 2000.
} 
heroína - fator que se supõem levar ao cometimento de crimes - sem, no entanto, apresentar os mesmos efeitos alucinógenos. Imaginava-se que substituindo a heroína pela metadona, e progressivamente reduzindo as suas doses, seria possível livrar as pessoas do vício. Porém, a metadona provou, de um lado, criar tanta dependência quanto a própria heroína, e de outro, proporcionar efeitos psicoativos que podem despertar um interesse de mercado. De tal modo, tão logo essa substância começou a ser distribuída pelo Estado, seja nas ruas, seja no cárcere, estruturou-se um mercado informal e ilegal de sua distribuição - mercado que levou o filho de Manola de volta à prisão.

Essa passagem é contada por Filip, professor de história de "La Modelo", que trabalhou por uma década como enfermeiro nessa mesma instituição prisional, e que antes disso, entre 1992 e 1994, trabalhara no Centro de Asistencia y Seguimiento para Drogodependientes (CASD) de Barceloneta, bairro da região central de Barcelona.

Filip, nascido em 1968 e filho de pais catalães, foi recrutado para esse primeiro trabalho ainda cursando o último ano da faculdade de enfermagem. As Olimpíadas se acercavam e havia alta demanda de mão de obra qualificada para trabalhar nas dezenas de CASDs que foram abertos para funcionar no período. Filip conta que os principais bairros e cidades satélites contavam com um CASD, e que nas localidades onde não foram construídos, um CASD móvel fazia o atendimento, distribuindo a metadona. Havia um cadastro unificado de todos os pacientes do programa, e aqueles que ficassem um certo período sem se apresentar já passavam a constar na listagem de procurados da polícia. Um programa de tratamento e uma nova forma de controle, portanto. Passados os jogos olímpicos, muitos CASDs foram fechados, o CASD móvel desapareceu, mas o de Barceloneta prosseguiu funcionando, pois era um CASD de referência, que oferecia além da metadona, programas de tratamento diversificados, como palestras e grupos terapêuticos. Filip gostava do trabalho, mas queria novos desafios, e por isso procurou um posto no sistema penitenciário.

Contratado em 1994, passou a trabalhar no programa de metadona da "Cárcel Modelo". No começo, a exemplo do que fazia em Barceloneta, tentou desenvolver programas diversificados e complementares ao tratamento, com palestras, conversas e grupos terapêuticos; mas, as dificuldades impostas pela equipe de segurança eram imensas e intransponíveis. Ao mesmo tempo, já começava a circular nos meios médicos a nova 
maneira de formular os objetivos do programa: ao invés da cura, a gestão de riscos e redução de danos. Ou seja, passava-se à consideração de que um paciente sob tratamento constante ofereceria menos riscos à sociedade e provocaria menos danos a si próprio e aos outros - tanto no que diz respeito aos riscos da criminalidade, quanto aos riscos do HIV. ${ }^{87}$ Para Filip, essa mudança na racionalidade do tratamento esvaziava todo o seu interesse no trabalho, e foi para mudar de área que ele decidiu retomar os estudos, cursando história na Universidade de Barcelona (UB).

Não obstante essa espécie de rebaixamento nos objetivos estratégicos do programa, é importante ressaltar que a estruturação de um aparato de tratamento farmacológico da dependência química - como eixo organizador do dispositivo penitenciário, na passagem das décadas de 1980 e 1990 - envolvia a estruturação de um verdadeiro complexo médico-hospitalar de assistência ao preso, que podia e era mobilizado para todas as outras questões de saúde.

Aurora conta que, a partir desse período, as instituições penitenciárias disponibilizam serviços médicos 24 horas por dia, com médicos, enfermeiras e auxiliares, que trabalham num consultório instalado em cada pavilhão. Consultas são diariamente realizadas, tratamentos simples são feitos e acompanhados de perto pelos profissionais. Existem equipes de especialistas - dentistas, oftalmologistas, urologistas, cardiologistas, etc. - que circulam pelas prisões, prestando atendimento. Em cada prisão ainda existe uma enfermaria central, onde são internados presos doentes que exigem maiores cuidados. E para aqueles casos em que nem a enfermaria da unidade é considerada um lugar adequado para o tratamento, foi criado, em 1992, o Pavelló Hospitalari Penitenciari de Terrassa, na coroa periférica de Barcelona, onde se disponibilizam leitos de terapia intensiva, salas cirúrgicas, etc. Só para se ter uma idéia dos efeitos desse processo de estruturação de um aparato médico-hospitalar no interior do sistema penitenciário, vale destacar que a incidência de tuberculose nas prisões de Barcelona, a partir de 1992, diminuiu em média $25,2 \%$ ao ano - uma taxa de redução maior que a da população em geral. ${ }^{88}$

\footnotetext{
${ }^{87}$ Para uma discussão acerca da gestão dos riscos nas políticas assistenciais, sanitárias e criminais, ver: MITJAVILA $(1999,2002)$.

${ }^{88}$ cf. SANZ (2003)
} 
Ao lado desse impressionante aparato médico-hospitalar acoplado às instituições prisionais, estruturava-se, ademais, um aparato educativo-escolar - para o qual Filip migraria depois de terminado o curso de história, e em cuja estruturação Angel Marzo ${ }^{89}$ desempenhou um papel fundamental. Segundo Marzo, a formação educacional oferecida nos ambientes prisionais catalães, no final dos anos 1980, reduzia-se a programas compensatórios de alfabetização de adultos, mas no decorrer dos anos 1990 vai se reproduzindo progressivamente no interior da prisão a estrutura educacional existente do lado de fora, com educação primária, secundária, média, profissional e até universitária (com a implantação de cursos a distância); ainda cursos de informática, castelhano e catalão para estrangeiros, de artes e educação física completam o quadro de atividades educativas.

A estruturação dos serviços médicos e educativos no interior das prisões catalãs introduziu na categoria dos servidores prisionais uma clivagem importante, entre as equipes de segurança e de tratamento. A conflitiva dinâmica - os desajustes - entre os dois coletivos é objeto das análises sociológicas de Zino (1995, 1997). Segundo esse autor, a disputa por hegemonia entre esses diferentes grupos de funcionários expressa de uma maneira muito concreta um dilema fundamental das instituições penitenciárias: a prisão servirá para punir ou reabilitar? Em torno dessa questão central do dispositivo carcerário todo um campo de disputa se arma, uma disputa discursiva pela "verdadeira" função da prisão, mas também uma disputa prática e cotidiana, que tem a ver com quais procedimentos serão tomados e quais demandas serão atendidas em situações muito concretas. Zino sustenta que, não obstante os setores mais ligados à segurança - aqueles que privilegiam mais as funções punitivas da prisão - sejam, na maior parte das vezes, hegemônicos; em determinadas conjunturas e em conseqüência de determinados acontecimentos, essa relação pode se inverter. Em "Coyunturas de cambio de una cultura institucional" (1997), o autor analisa uma dessas situações, que teve lugar em "La Modelo" no final dos anos 1980. Depois de uma greve de internos - que reivindicavam o mesmo tratamento para presos sociais e aqueles pertencentes a organizações políticas $\operatorname{armadas}^{90}$ - a represália violenta do setor de vigilância desencadeou um crescente de conflitos entre presos e funcionários, dos quais a equipe

\footnotetext{
${ }^{89}$ Professor e pesquisador especialista em educação de jovens e adultos, entrevistado em 2008, ver Capítulo 4 dessa dissertação.

${ }^{90}$ Sobre a atuação de grupos políticos armados no período democrático, ver: ROCA (1994).
} 
de tratamento ficava relativamente alheia. A administração penitenciária destituiu os principais diretores da instituição, considerando-os inábeis para solver a questão. A nova junta diretiva nomeada, para iniciar sua gestão, quis adotar uma postura de maior diálogo com os presos, e para tanto, apoiou-se exatamente nos funcionários do setor de tratamento que não haviam se envolvido diretamente nos conflitos. Dessa forma, a equipe de tratamento se fortaleceu frente ao pessoal da vigilância.

De todo modo, pelo que relata Filip, essa inversão nas relações de poder no corpo de funcionários não se manteve por muito tempo. Como já foi apontado, quando ele começou a trabalhar no programa de metadona da prisão - buscando desenvolver projetos terapêuticos análogos aos que vira no CASD de Barceloneta - era a equipe de vigilância que se opunha, por questão de segurança, à realização de reuniões, aos horários das palestras, às movimentações de presos, etc. Mesmo quando Filip migrou para o aparato educativo-escolar, as limitações impostas pelos imperativos da segurança dificultavam a realização de seus projetos de ressocialização. Depois de alguns anos como professor de história de ensino secundário, ele assumiu a direção do departamento de ensino superior à distância de "La Modelo". Muito empolgado num primeiro momento, foi incentivando os presos aos estudos universitários, conseguiu uma sala com computadores para a realização de trabalhos, aumentou a biblioteca, etc. Porém, foi impedida, por alegadas questões de segurança, a conexão dos computadores à internet para que os presos realizassem pesquisas. Filip, então, travou uma luta com a equipe de vigilância, estudou as possibilidades de acesso seletivo e controlado de conteúdos da rede, fez um projeto detalhado que parecia provar a viabilidade desse imprescindível recurso à pesquisa universitária, levou-o aos mais altos escalões da administração da unidade. No final, a resposta negativa veio acompanhada de ponderações sobre como, numa instituição punitiva como a prisão, o acesso à internet representaria demasiada regalia. Desiludido, Filip abandonou o ensino superior e retornou para o secundário. 


\section{7 - (I)migrantes}

Tanto Aurora e Filip, como Zino e Marzo, são unânimes em apontar que a população preferencialmente encarcerada nas prisões catalãs, durante a década de 1980 e a primeira metade dos anos 1990, dividia-se em dois grupos: os "payos" e os "gitanos". "Payo" é a palavra caló ${ }^{91}$ utilizada para falar do outro, do não-cigano, também significa aldeão, camponês, ou seja, assentado na terra. "Gitano" "92 é o cigano espanhol, a palavra designa um grupo étnico, com uma história, uma língua e uma identidade, geralmente conhecido pelo nomadismo - apesar de amplos setores desse coletivo já não adotarem essa prática. Os ciganos são a minoria étnica mais numerosa da Europa, onde já sofreram uma série de perseguições, desde 1499, quando uma ordem dos Reis Católicos determinou a sua expulsão do território espanhol, até a Alemanha nazista, onde coletivos inteiros foram exterminados, ao lado dos judeus, nas câmaras de gás. Se escrever sobre "La Modelo" remete ao desenvolvimento do poder disciplinar na Espanha; escrever sobre a questão "gitana" remete ao desenvolvimento do poder soberano na Europa. Por isso, seria impossível reconstituir aqui o percurso histórico da marginalização do povo "gitano" naquele país, bem como fazer uma análise aprofundada de suas relações sociais internas e com outros coletivos.

Assim, limito-me a pontuar nessa cartografia que, desde a década de 1950, os grupos "gitanos" em Barcelona - muitos provenientes do sul do país juntamente com outros migrantes - constituíam foco privilegiado de incidência do dispositivo carcerário. A eles era associado o estigma da criminalidade, eram especialmente vigiados, viviam em inúmeros bairros marginalizados construídos nas colinas ao redor da cidade, na zona marítima e nos interstícios do Eixample, em casas precariamente edificadas, conhecidas como "barracas" ou "chabolas". Era nesses espaços degradados que a "epidemia" da heroína proliferava. ${ }^{93}$ Os "gitanos" foram também um contingente muito significativo nos polígonos de moradia construídos nas cidades satélites de Barcelona, entre os anos

\footnotetext{
${ }^{91}$ Idioma dos ciganos.

${ }^{92}$ Para maiores informações sobre os ciganos na Espanha, ver: GIMÉNEZ (1994).

${ }^{93}$ Para uma visualização dessa realidade, ver o filme documentário intitulado "Can Tunis", que, no começo dos anos 2000, acompanha o desaparecimento de um bairro "gitano", derradeiro território de tráfico e consumo de heroína na zona portuária de Barcelona: TOLEDO e MORANDI (2007).
} 
1960 e $1970^{94}$, como Sant Ildefons, em Cornellà; Sant Roc, em Badalona e La Mina, em Sant Adrià del Besòs - polígonos que, na tentativa de elimiar o "chabolismo", ficaram conhecidos como expoentes de "barraquismo vertical", tanto pela composição populacional, pela precariedade da moradia, do acesso e dos serviços disponibilizados, como pela forte incidência do problema da droga. Seguramente, a sobrerepresentatividade da população "gitana" nas prisões catalãs se relacionava com essa sobre-representatividade nos territórios de marginalização social.

Uma clivagem secundária na população carcerária-marginalizada de Barcelona dos anos 1980 e começo dos 1990 - e que em grande medida se comunica com a primeira - foi destacada por Manola: a divisão entre "charnegos" e "catalanes". "Charnego" é a designação depreciativa para os imigrantes sulistas (como ela e seu filho), que compartilhavam uma imagem social híbrida ou indefinida, meio "payo", meio "gitano", nem totalmente uma coisa, nem outra. Catalães, por sua vez, eram considerados os que podiam manejar bem o idioma local. Tem-se assim um sistema relativamente simples de segmentação das populações sobre as quais havia maior incidência do dispositivo carcerário, até meados dos anos 1990: uma divisão primária entre "payos" e "gitanos"; e entre os "payos", uma divisão secundária entre "catalanes" e "charnegos".

Em cada apreciação valorativa, há uma espécie de avaliação de grau de pertencimento, feita por um cálculo do nomadismo potencial ou do passivo-migratório que uma ou outra identidade encerra. O "gitano", secular e ameaçador nômade "por natureza", a ser sempre e exaustivamente fixado, ocupando o centro do dispositivo; ao seu lado, o "charnego", migrante espanhol sulista, suspeito porque desenraizado; e na periferia do dispositivo, o catalão que circulando por enclaves "gitanos" e "charnegos" encontra a heroína e, por sua causa, perde-se nas sendas do crime. Nestes termos, é possível perceber uma linha de continuidade subjazendo entre esse dispositivo carcerário reformulado por uma abordagem farmacológica da criminalidade, e aquele dispositivo disciplinar emergente nos séculos XVIII e XIX, que como demonstrou Foucault (1996) já incluía entre seus objetivos estratégicos, a fixação de populações flutuantes.

\footnotetext{
${ }^{94}$ Para um panorama da evolução recente do problema urbano de Barcelona, ver: DELGADO (2007). Sobre o processo de construção de polígonos de moradia popular na coroa periférica de Barcelona, ver: COSTA et. al. (2003); e para situar esse processo numa perspectiva histórica mais ampla, ver: TATJER (2005).
} 
Mas se nesse período os jogos de pertencimento já ocupavam uma posição estratégica no dispositivo carcerário, a partir do final da década de 1990, com a intensificação da imigração internacional na Espanha, o problema das populações flutuantes se desdobra numa nova escala.

No decorrer da década de 1990, um conjunto complexo de processos sociais, políticos e econômicos promoveu a intensificação de fluxos migratórios internacionais, reconfigurando as fronteiras e mercados nacionais, e conformando o que ficou conhecido como "globalização". A emergência da imigração internacional como um problema na Europa motivou a adoção de medidas restritivas, de controle e repressão à imigração clandestina, principalmente naqueles países em que ela se fazia mais presente, como França, Alemanha e Áustria. Na medida em que foi se tornando cada vez mais difícil para imigrantes estrangeiros aportarem diretamente nos países mais ricos do norte do continente, vias alternativas foram sendo criadas, muitas delas passando pela Espanha. A proximidade territorial da África, a existência de territórios espanhóis no Marrocos - as cidades de Celta e Melilla - e na costa do continente africano - as Ilhas Canárias - transformaram a Espanha em porta de entrada do continente. ${ }^{95}$ Raciocínio análogo se aplica na questão da permanência: conforme ficava mais difícil permanecer e trabalhar nos países do norte europeu, o sul - principalmente Espanha e Itália, que experimentavam um ciclo de crescimento econômico - tornava-se mais atrativo.

Só na segunda metade da década de 1990, a população imigrante estrangeira na Espanha duplicou. Seria possível afirmar que o aumento da população imigrante estrangeira (legal e clandestina), na Espanha, arrebatou o dispositivo carcerário, impondo todo um conjunto de reestruturações táticas e estratégicas, bem como importantes deslocamentos no campo de disputas que se estrutura a partir da prisão. Tal arrebatamento vai se tornando mais e mais evidente no decorrer dos anos 2000, quando a população imigrante estrangeira não pára de crescer dentro e fora das prisões catalãs.

Considerando que Barcelona era uma das cinco províncias que concentravam $60 \%$ da população estrangeira do país, é possível vislumbrar o impacto que essa importante

\footnotetext{
${ }^{95}$ Para um panorama abrangente sobre a imigração internacional na Espanha, ver: DÍAZ, MIRANDA e ENRÍQUEZ (2001)
} 
alteração demográfica teve no dispositivo carcerário que operava naquela localidade. ${ }^{96}$ O relato da experiência profissional de Aurora, que em 1994 começou a trabalhar em "La Modelo", é um testemunho desse arrebatamento.

No decorrer do final da década de 1990, ela testemunhou uma significativa redução de volume de trabalho no programa de metadona. Os dependentes da heroína ou morriam ou eram soltos, e um novo perfil de preso começava a surgir, com a chegada cada vez maior de estrangeiros, num primeiro momento, principalmente magrebinos e latinoamericanos. Aqueles anos 1990 eram de expressivo crescimento econômico, e de explosão do mercado imobiliário barcelonês - efeito direto do sucesso das Olimpíadas que atraía uma expressiva força de trabalho não qualificada estrangeira. Aurora conta que com o passar do tempo, nos anos 2000, o grupo de estrangeiros da prisão foi crescendo e se diversificando: chegaram os africanos subsaarianos; os europeus do leste; os paquistaneses, indianos, filipinos, etc. A globalização chega a "La Modelo" (e também aos bairros marginalizados da região metropolitana de Barcelona) com um efeito imediato: o jogo de pertencimentos que organiza a incidência diferencial do dispositivo carcerário se desdobra e se complexifica. A população prisional passa a diferenciar-se ora entre muçulmanos e cristãos; ora entre falantes e não falantes do espanhol; ora entre europeus comunitários e não comunitários, etc.

Nesse novo contexto, o tratamento penitenciário focado numa abordagem médicahospitalar do criminoso torna-se residual. A urgência da criminalidade associada à "epidemia" de heroína dá lugar ao problema da criminalidade associada à imigração clandestina, de tal modo que as práticas punitivas e de controle que conformam o dispositivo carcerário são amplamente reconfiguradas. Aurora, por exemplo, para seguir cumprindo suas funções de toda a vida está lotada, desde 2004, no sub-setor de psiquiatria da enfermaria da prisão, único ponto em que permanece a mesma dinâmica de tratamento que marcou o começo de sua experiência profissional. Filip, como já foi indicado, migrou para o setor de educação, e hoje atua como professor de história do ensino secundário, além de dar aulas de normalização lingüística, ensinando espanhol e catalão para estrangeiros.

\footnotetext{
${ }^{96}$ Mais informações sobre a imigração e a população carcerária estrangeira na Catalunha estão no Capítulo 2 dessa dissertação.
} 
De fato, segundo Filip, o setor educativo da equipe de tratamento da prisão vai ganhando cada vez maior centralidade na operacionalização das tarefas mais básicas do cotidiano prisional, como comunicar uma transferência, requisitar uma audiência, explicar a acusação, etc. Ou seja, não necessariamente as funções ressocializadoras da prisão passam a prevalecer sobre sua quase sempre hegemônica função punitiva, mas sim o aparato educativo-escolar que é reinvestido de função estratégica: viabilizar a mínima comunicação do setor de vigilância com grande parcela dos presos. De todo modo, a rígida estrutura escolar se mostra insuficiente para dar conta das novas demandas que vão emergindo com a transformação da população carcerária.

\section{8 - Novas peças}

Frente às novas urgências, novos aparatos se estruturam no interior do dispositivo. Um muito importante deles poderia ser chamado de voluntário-assistencial. Basta lembrar o bem sucedido projeto voluntário de Raquel Sala em "La Modelo" - dinamizando as redes de comunicação por onde se divulgariam as atividades esportivas do presídio $^{97}$-, que lhe garantiu um posto de trabalho na administração penitenciária, para dimensionar a importância que vem sendo dada a esse tipo de atividade. Atualmente, a SSPRJJ admite projetos de voluntários nas áreas de "assistência jurídica; animação sóciocultural; promoção da saúde; formação; esportiva; acompanhamento educativo; acompanhamento na comunidade" ${ }^{98}$, tanto para presos, egressos, como também junto àqueles que estão cumprindo medidas penais alternativas. Desde 2001, realizam-se periodicamente Jornadas de Voluntariado Penitenciário, nas quais as entidades e voluntários trocam experiências, discutem os projetos e se qualificam. Desde 2004, também são oferecidos regularmente pela secretaria cursos de formação do voluntariado penitenciário, destinado àqueles que já desenvolvem projetos ou que tem interesse em fazê-lo. Nas últimas Jornadas, em 2009, foi divulgada a existência de 27 entidades

\footnotetext{
${ }^{97}$ Ver Capítulo 4 dessa dissertação.

${ }^{98}$ Texto encontrado no site da SSPRJJ, disponível na internet via: http://www20.gencat.cat/portal/site/Justicia/menuitem.51bb51de98b3c1b6bd6b6410b0c0e1a0/?vgnextoid =2b94f31f87203110VgnVCM1000008d0c1e0aRCRD\&vgnextchannel=2b94f31f87203110VgnVCM100 0008d0c1e0aRCRD\&vgnextfmt=default (Consulta feita em maio de 2010)
} 
cadastradas realizando atividades junto ao sistema penal, envolvendo um total de 366 voluntários (TAULA DE PARTICIPACIÓ SOCIAL, 2009, p.2) - número que supera os 258 funcionários que, no mesmo ano, trabalhavam no aparato médico-hospitalar (SSPRJJ, 2010).

Três marcações devem ser feitas a respeito desse novo aparato que se estrutura acoplado ao sistema penitenciário: 1 - ele constitui um importante campo articulador de agentes, práticas e discursos que circulam tanto dentro, quanto fora do sistema penitenciário; 2 pela alta rotatividade dos voluntários - problema reconhecido e debatido nas jornadas ${ }^{99}$ - o número de pessoas que acaba por envolver com as questões prisionais supera em muito o contingente atual de voluntários; e 3 - a Coordinadora Contra la Margináció de Cornellà, desde que formalizou suas atividades, é uma das entidades que compõem e estruturam esse campo.

O desenvolvimento e a ativação desse novo campo societário junto às instituições prisionais complexifica a imagem do "Estado Penal" - segregacionista e anulador -, que, segundo alguns autores ${ }^{100}$, vem caracterizando o contexto punitivo espanhol nos últimos anos. Não se pretende com tal afirmação refutar a existência desse "Estado Penal" - desde Wacquant (1998, 2001, 2007), em toda parte visto como a grande causa do processo de massificação do encarceramento - mas, tão somente, pretende-se apontar para o fato de que, numa cartografia descritiva do dispositivo carcerário contemporâneo, é possível identificar a emergência de aparatos que não necessariamente seguem uma mesma racionalidade punitiva. São aparatos como o voluntário-assistencial, o médico-hospitalar e o educativo-escolar que dão a medida da heterogeneidade de agentes, práticas e discursos que conforma o dispositivo. A afirmação da prevalência de uma estratégia dominante segregacionista e anuladora no interior do dispositivo, ganha maior relevância ainda se articulada, de um lado, a uma problematização acerca de outras possibilidades estratégicas que se apresentam num dado momento; e de outro, a uma análise das formas pelas quais a estratégia dominante

\footnotetext{
99 cf. TAULA DE PARTICIPACIÓ SOCIAL (2009).

100 Toda uma bibliografia vem se desenvolvendo para tratar criticamente do endurecimento penal espanhol, do aumento das taxas de encarceramento, do aumento da população prisional imigrante, e para desfazer e denunciar um discurso que associa o aumento da criminalidade à imigração. Seguindo mais ou menos de perto as sugestões acerca do "Estado Penal" e da gestão penal da miséria, feitas por Wacquant, os autores denunciam o que consideram uma gestão penal da imigração, que se fundamenta na repressão e na negação de direitos. Referências imprescindíveis dessa reflexão são: OSPDH (2005), NETO (2009),

MASÓ (2002), CALAVITA (2003) e WAGMAM (2002, 2003).
} 
coloniza, reinveste, (i)mobiliza ou utiliza as forças que se articulam sob uma estratégia subsidiária.

\section{9 - (I)mobilizações}

Por volta de 2002, o pai de Manola faleceu, seu filho seguia preso, e ela decidiu retomar as atividades junto à Coordinadora. Fez os devidos contatos, e descobriu que o grupo de mães e as assembléias gerais de todas as terças-feiras seguiam acontecendo, agora na nova sede da instituição, no piso térreo de um bloco de moradia, em Sant Ildefons. Ela voltava num período crítico e determinante da evolução da entidade: um conflito estava deflagrado entre os jovens militantes que, no começo dos anos 1980 começaram a articular as reuniões, e o setor de senhores e senhoras religiosos que se aproximou posteriormente, em grande parte devido à própria articulação de Manola. Dois projetos de organização da sociedade civil estavam em disputa, e o retorno de Manola só conseguiu adiar a ruptura.

O leque de parcerias e comprometimentos da entidade com diferentes instituições públicas e privadas havia se ampliado muito desde que Manola deixara de freqüentar as reuniões. Recibaix, por exemplo, contava com uma equipe de gestores profissionais financiado pela prefeitura de Cornellà; havia estabelecido um contrato com a secretaria responsável pela limpeza urbana, recebendo caminhões e balanças; uma loja de artigos restaurados havia sido aberta e um educador social havia sido contratado para trabalhar junto aos egressos, ambos através de parcerias com fundações empresariais e bancárias. Para alguns, avanços como esses representavam a profissionalização e um salto de eficiência para os projetos da entidade - um ganho de capacidade de mobilização; para outros, tais parcerias representavam um refreamento na capacidade de denúncia e reivindicação do coletivo - imobilização. O conflito não se dava somente no nível da concepção de entidade, tinha implicações muito concretas. Outro exemplo: numa visita a presos de Cornellà em Can Brians, os agentes da entidade identificavam maus tratos; um setor da entidade defendia que se fizesse uma manifestação na porta da prisão ou da SSPRJJ, denunciando os fatos; outro setor defendia que se marcasse uma reunião com 
os gestores da prisão e da secretaria para apurar os acontecimentos e propor soluções, ponderando que uma manifestação pública poderia minar a credibilidade da organização, comprometendo os contratos e parcerias possíveis e existentes.

O mesmo conflito eclodia nas mais variadas situações. Manola buscava mediar diplomaticamente as crises, mas a polarização no interior da Coordinadora parecia-lhe irreversível. O conflito não repercutiu numa ruptura total da entidade em duas, mas o bloco religioso foi impondo sua hegemonia. Entre 2002 e 2005, progressivamente os integrantes mais afeitos a uma postura de confrontação política foram abandonando individualmente - a atuação, até o ponto de que restasse somente Manola daqueles tempos iniciais da organização.

Assim é que Manola descreve a transição da Coordinadora de um perfil originário político-reivindicativo para o atual perfil voluntário-assistencial, que coloca a entidade em outra relação com o restante do dispositivo. Em 2006, quando se consolidava a nova situação da entidade, Manola foi indicada para ocupar a posição de presidente da organização, uma vez que ela era a única que vivenciara os primórdios do coletivo. Ela ainda ocupava essa posição quando freqüentei as assembléias e a entrevistei. Desempenhava um papel de figura pública, compunha a mesa dos diversos debates e dava entrevistas para jornalistas. Porém, como podia observar e como ela mesma me confirmou, sua origem, sua história e a posição de destaque que ocupava serviam mais como uma espécie de "avalista" para legitimar publicamente a entidade, do que lhe garantia efetivo poder de direção. A direção política da organização ficava a cargo do secretário geral, padre e histórico apoiador dos movimentos populares de Cornellà.

É importante fazer essa marcação: o grupo religioso que hegemonizou a Coordinadora, não o fez como um plano maquiavélico de desmobilização, mas antes pela convicção de que novas práticas se fazem necessárias em tempos de democracia consolidada. Conheci muitos dos senhores e senhoras que compunham esse campo e todos eles apresentavam trajetórias de luta anti-franquista, de apoio aos movimentos populares de moradia e operário, e que atualmente tinham um forte comprometimento com "as causas" dos presos. Manola, sabendo disso, não os responsabiliza por um possível fracasso da entidade; faz uma avaliação de que a entidade que conheceu está para se acabar, mas isso a despeito do comprometimento político de seus atuais gestores. Segundo ela, não foi a Coordinadora que se descolou de suas bases sociais por uma questão ideológica, 
ou uma traição de princípios originários, foram as bases que se transformaram, por questões tão concretas quanto o aumento da imigração e a transformação da população residente em bairros periféricos de Cornellà, como San Ildefons, que de "gitana" e "charnega" passa a ser, majoritariamente, marroquina, paquistanesa, latino-americana, etc.

Uma semelhante análise de conjuntura, mas com maiores detalhes informativos, é feita por Xavi, que foi secretário administrativo da Coordinadora de 2006 até 2008. Xavi, filho de pai catalão e mãe andaluza, nasceu em 1979, em Cornellà. Desenvolveu atividades de militância em grupos anarquistas desde a juventude, cursava história e estava organizando um movimento de apoio à regularização de um grupo de imigrantes em Cornellà, quando foi convidado pelo padre e secretário geral a participar das atividades da Coordinadora. O padre lhe disse que era preciso gente jovem e comprometida participando da entidade, naquele exato momento em que os mais jovens e combativos iam deixando a organização. ${ }^{101}$ Xavi aceitou o desafio, e por essas vias que entrou em contato com o mundo prisional. Começou realizando visitas a presos do bairro em diferentes unidades, e logo foi convidado a trabalhar na secretaria da organização. Como secretário, Xavi tinha acesso aos pormenores das dificuldades enfrentadas pela entidade para se viabilizar no novo contexto do bairro, bem como das novas estratégias que vinham sendo desenvolvidas para contornar essas dificuldades.

Segundo ele, familiares de imigrantes presos até chegavam a procurar a entidade em busca de auxílio, porém uma série de questões se interpunham à consolidação de uma relação de colaboração efetiva. Em primeiro lugar, os advogados que prestavam serviço para a entidade eram financiados pela prefeitura de Cornellà, o que exigia que os assistidos tivessem condições de comprovar documentalmente uma relação estável com a cidade satélite - requisito dificilmente cumprido pelos imigrantes clandestinos. Em segundo lugar, muitos dos que cumpriam esse requisito chegavam à entidade encaminhados pela própria SSPRJJ, de tal modo que viam na organização uma prestadora de serviços ligada ao Estado, e não uma associação comunitária. Quando descobriam que uma das contrapartidas da assistência jurídica era a participação em assembléias e outras atividades, muitos dos demandantes desistiam. Em terceiro lugar,

\footnotetext{
${ }^{101} \mathrm{O}$ conflito entre membros fundadores e o grupo religioso que se somou posteriormente à organização também pode ser visto como um conflito de gerações, sendo os fundadores mais jovens do que o grupo ligado à Igreja Católica.
} 
Xavi identificava certo preconceito dos associados com relação aos imigrantes, não exatamente pela sua origem, mas antes pela natureza de seus delitos. Muitos daqueles pais e mães que participavam da entidade por anos a fio tiveram seus filhos presos nos anos 1980 e 1990 em decorrência de crimes contra a propriedade relacionados à dependência química; já os presos imigrantes dos anos 2000, majoritariamente, eram detidos por delitos relacionados à operacionalização do tráfico de drogas. Prestar assistência a um traficante era como ajudar aquele responsável indireto pela prisão de um ente querido. Xavi afirma que esse conflito de fundo nunca era formulado explicitamente, mas que podia percebê-lo em diferentes situações.

Tais elementos faziam com que, de fato, o campo de atividade da Coordinadora relacionado à prisão se restringisse, nos anos 2000, ao mundo dos migrantes sulistas espanhóis, isto é, à população mais antiga da cidade. Manola agrega um outro elemento para ilustrar essa desconexão da entidade com a realidade atual da localidade: no grupo de mães, boa parte das mulheres que participam já tiveram seus filhos mortos, ou como ela - já estão habituadas a tê-los na prisão, ou seja, não houve renovação, não obstante o continuado aumento do encarceramento no bairro.

Para reverter essa difícil situação, a Coordinadora vem investindo na diversificação de suas atividades. É nesse sentido que foi desenvolvido o projeto de qualificação profissional para jovens com trajetória de fracasso escolar, intitulado La Carena. Esse é o único projeto da organização em que o público alvo é majoritariamente de origem estrangeira. O discurso de justificação do projeto, sem descolá-lo do conjunto de atividades promovidos pela entidade, é o da prevenção do delito. $\mathrm{O}$ ensinamento de ofícios ligados à construção civil e informática para jovens de origem imigrante, que não se adaptam ao ambiente escolar, é investido de uma racionalidade preventiva, informada pela identificação de grupos de risco e pela projeção de uma inserção social adequada, segundo o horizonte do "possível". Para seguir promovendo atividades como essa, ampliando o La Carena e desenvolvendo outros projetos análogos, a junta diretiva da Coordinadora contra la Marginació de Cornellà já estuda a mudança de nome da entidade para algo mais positivo, mais propositivo (mais preventivo), que ao invés de remeter aos conflitos dos anos 1970, 1980, remeta a um futuro inclusivo e pacífico. Manola e Xavi consideram válidas essas práticas e reflexões, porém as vêem destoar sobremaneira da história e perfil da instituição. Por essas e outras questões, Xavi ao se 
formar em história pela UB deixou o trabalho na secretaria da entidade e passou a lecionar; e que Manola prevê, em breve, o fim da Coordinadora, pelo menos tal como ela a conhecia.

\subsection{0 - (In)conclusões}

Essa cartografia do dispositivo carcerário que opera na Catalunha é inevitavelmente parcial e inconclusa, porque feita seguindo um roteiro de busca por um bairro significativamente afetado pelo aumento do encarceramento, e composta com outros roteiros de diversos agentes que se conformam e atuam no interior do dispositivo carcerário, tanto dentro, quanto fora das unidades prisionais. Ainda que, por um lado, não tenha podido incluir alguns dos percursos trilhados no decorrer do trabalho de campo, e por outro, não tenha podido ao menos identificar outras estruturações societárias, campos de problematização e processos de transformação que são tão ou mais importantes do que esses aqui esboçados, a cartografia que se apresentou tem o potencial de demarcar algumas importantes regiões e passagens do dispositivo carcerário catalão, e de demonstrar o quanto, em torno da prisão, gravitam e se polarizam agentes, práticas e discursos, constituindo, efetivamente, um expansivo e complexo campo que supera em muito os limites físicos da instituição prisional. 


\section{7 - Uma cartografia do dispositivo carcerário paulista}

O capítulo anterior assume um caráter fundamentalmente prospectivo na medida em que trata da exploração de um campo desconhecido, cujos mais variados aspectos da realidade carcerária e do mundo que se organiza a sua volta, são absolutamente novos para o pesquisador. Impossível referir-se à realidade brasileira, e principalmente paulista, nos mesmos termos. Ser nascido e criado no estado de São Paulo impõe um esforço de discernimento crítico e reflexivo para bem situar os achados de campo e as informações secundárias na elaboração de uma cartografia do dispositivo carcerário paulista. Se na Catalunha, o esboçar percursos, pontuar marcos e referências que compõem a cartografia se dava sobre um mapa praticamente em branco; em São Paulo, pelo contrário, o esforço é de destacar os percursos, marcos e referências em um mapa que é sobre-codificado, repleto de indicações cruzadas, de trilhas repisadas e sobrepostas, que foi, em suma, construído não só no decorrer da pesquisa, mas em toda uma vida.

Não obstante uma maior quantidade e melhor qualidade de referências externas ao percurso, que puderam ser mobilizadas na sua orientação, obstáculos, desvios e atalhos análogos aos encontrados na Espanha, também aqui se apresentaram. Também em São Paulo, a busca dos efeitos societários territorializados do aumento do encarceramento se desdobrou numa deambulação de meses pelas sendas do dispositivo carcerário, resultando num parcial, provisório e inconcluso exercício cartográfico.

\section{1 - Marco Zero}

O ponto de partida dessa cartografia se situa na zona norte da cidade de São Paulo, no que ficou conhecido como "Complexo do Carandiru", um conglomerado de instituições prisionais, que, por décadas, abrigou duas das mais importantes prisões do estado: a Penitenciária do Estado e a Casa de Detenção. Na dinâmica de lenta estruturação desse 
complexo se encontra uma chave para a compreensão de todo o desenvolvimento ulterior do dispositivo carcerário paulista. ${ }^{102}$

Desde muito antes da construção do complexo, ainda no período colonial, o sistema penitenciário paulista era um conjunto de cadeias espalhadas por todo o território, construídas sob sedes administrativas municipais, portanto, nos centros das principais vilas e cidades. Na cidade de São Paulo, esse edifício que misturava funções administrativas e repressivas se situava no Largo de São Gonçalo (atual Praça João Mendes).

Durante o período imperial, ensaiaram-se os primeiros esforços de modernização da punição, especializando um edifício para esse fim específico. Foi inaugurado então, em 1852, na Avenida Tiradentes, a Casa de Correção de São Paulo. Até o final do século XIX, o foco do aparato punitivo eram os escravos fugidos, ou aqueles para a prisão enviados pelos seus senhores, como castigo. Somavam-se a eles, crianças, mulheres, vadios, loucos e criminosos de pequena monta. A confusão, a precariedade das instalações, a proliferação dos vícios e doenças, os altos índices de mortalidade que caracterizavam as antigas prisões coloniais, rapidamente se estenderam para a nova Casa de Correção, fazendo dela também um alvo recorrente de críticas - que ressaltavam a sua incapacidade de fazer valer o código penal imperial de 1830, o qual já incluía intenções regeneradoras em seus postulados da pena de prisão.

A permanência das críticas e intenções reformadoras frente a um também permanente estado calamitoso de cumprimento de pena deu a tônica da estruturação do aparato penitenciário em São Paulo. Rapidamente, a Casa de Correção ficou superlotada, degradada, infectada, aviltante, e a necessidade de uma nova instituição se impôs. Então, adaptaram, em 1876, o casarão em que vivia o diretor da unidade para funcionar como cadeia. E o ciclo recomeçava.

No período republicano, as críticas e debates sobre a precariedade do sistema punitivo paulista se intensificaram, e a necessidade de uma nova penitenciária, moderna e adequada, novamente se impôs. Depois de um lento processo de elaboração e construção, em 1920 foi inaugurado o marco inicial do Complexo do Carandiru, a Penitenciária do Estado - na ocasião, a Casa de Correção se tornou de detenção.

${ }^{102}$ As informações acerca da história do sistema prisional paulista estão em: SALLA $(1999,2000)$. 
A moderna arquitetura da nova penitenciária, em formato de espinha de peixe inspirada na prisão francesa de Fresnes - e um regime de cumprimento de pena bastante avançado - inspirado em prisões irlandesas - a colocavam na vanguarda da punição mundial. O contexto social em que emergia, e suas características programáticas sintetizadas na inscrição "Instituto de Regeneração" sobre o portão principal - entram em ressonância com o processo de emergência do poder disciplinar na França dos séculos XVIII e XIX, que foi explorado por Foucault (1996).

Nos primeiros anos do século XX, São Paulo também se industrializava e crescia vertiginosamente, tendo sua população duplicado entre 1900 e 1920. A chegada de escravos libertos do interior e a crescente imigração internacional multiplicavam as "classes perigosas" circulantes na cidade. O aumento da produção e circulação de riquezas entre, de um lado, ladrões, vadios, mendigos, e de outro, sindicalistas, socialistas e anarquistas, organizadores de greves e protestos, criavam as condições necessárias para a busca de expansão e racionalização do aparato punitivo.

O caráter de instituição disciplinar modelar, no entanto, resistiu por pouco tempo à superlotação, à mistura excessiva, às doenças e à alta mortalidade, de tal modo que uma série de ajustes foram progressivamente necessários. A exemplo do que já havia passado na Casa de Correção, em 1941, a casa do diretor da Penitenciária do Estado foi adaptada para receber o "Presídio de Mulheres". ${ }^{103}$ Mais adiante, em 1956, no intuito de (novamente) separar presos condenados de preventivos, foi inaugurado, ao lado da Penitenciária do Estado, o primeiro pavilhão da Casa de Detenção de São Paulo. No decorrer dos anos 1960 e 1970, a Casa de Detenção foi seguidamente ampliada e reformulada, até chegar a abrigar mais de 6.000 presos $-40 \%$ deles já condenados - em sete pavilhões, a meados dos anos 1970.

Ou seja, a estruturação do Complexo do Carandiru se dá num secular jogo entre pressões da superlotação e da profunda precariedade institucional, com medidas emergenciais, e esforços de criação de instituições modelares. O Complexo do Carandiru pode ser lido como um documento desse reiterado esforço de modernização, rapidamente sucedido pelo atestado de seu fracasso, que leva a criação de novas instituições, umas improvisadas, outras, novamente pensadas como modelares.

${ }^{103}$ Para uma história do Presídio de Mulheres do Estado de São Paulo, ver: ARTUR (2009). 
Considerando que esse processo de estruturação se desenvolve em paralelo com a existência e expansão de instituições prisionais locais, cadeias e xadrezes de delegacias espalhados pelo território estadual e ainda mais aviltantes que as unidades que compõem o Complexo - descendentes diretos das casas administrativo-repressivas do período colonial - Salla (2000) caracteriza a evolução da política penitenciária paulista por uma certa ambigüidade: de um lado a perpétua negligência frente os aspectos mais básicos da vida na prisão, e de outro, a reiterada tentativa (sempre fracassada) de criar “alguns estabelecimentos (...) como modelares, como símbolos destinados a ofuscar as mazelas da degradação das demais prisões." (SALLA, 2000, p.215)

Nestes termos, ainda que os programas disciplinares tenham cumprido um papel importante na estruturação do complexo - na definição arquitetônica, nos regulamentos internos - eles, aqui, nunca se realizaram, já que foi sempre a urgência, a precariedade, a degradação e a violência que pautaram a estruturação do aparato punitivo paulista. Nenhum princípio organizacional podia se manter frente à necessidade imperiosa de receber mais presos, de aglomerar mais gente: oficinas de trabalho virando celas, celas individuais se tornando coletivas, penitenciária se tornando casa de detenção provisória, e esta se fazendo penitenciária, num eterno movimento de expansão e de deterioro. Nesse ambiente prisional, as penas não decorrem pelos meandros da disciplinarização, da docilização dos corpos, mas pelos da sobrevivência e da violência exacerbada - que episódios como o Massacre do Carandiru colocam em evidência. Assim, o dilema fundamental do dispositivo carcerário paulista não é se o preso sairá regenerado ou corrompido; mas sim, se sairá vivo, e se vivo, se sairá lúcido.

É importante reter essa chave de leitura do dispositivo carcerário paulista: a precariedade do aparato punitivo constitui a marca histórica de sua existência, é a base de sua positividade no mundo, tudo que se estrutura a partir dele será positivamente, produtivamente condicionado por ela - porque em torno da precariedade também se estrutura um dispositivo, e é isso o que os interlocutores dessa pesquisa demonstram com os seus percursos e relatos.

Mas, antes de passar ao que apresentam desse dispositivo e de suas reconfigurações recentes, caberia adiantar algumas (macro)demarcações gerais que os situem em relação a outros campos e outros processos sociais. Os percursos recolhidos em trabalho de campo remontam, principalmente, à década de 1980, momento em que, na política 
nacional, vivia-se o final da ditadura militar e o processo de redemocratização; na economia, experimentava-se a abrupta passagem do "milagre econômico" à "década perdida"; nas grandes cidades, as últimas etapas de um forte processo de inchaço urbano por expansão de periferias; no mundo dos ilegalismos, começava a se estruturar o mercado nacional da cocaína e suas conexões com mercado global. Na década de 1990, um segundo momento, quando no campo político vivia-se o dilema da continuidade autoritária e da consolidação democrática; na economia, a abertura dos mercados, a reestruturação produtiva (com seus efeitos de desemprego e pauperização) e a estabilização da moeda; nas regiões de fronteira das periferias de São Paulo, a explosão do favelamento; e no mundo dos ilegalismos, as taxas de homicídio crescendo vertiginosamente, cada vez mais associadas ao comércio varejista de drogas, especialmente do crack. E nos anos 2000, o momento atual, quando, na política, o Partido dos Trabalhadores (PT) assume o governo federal; na economia, inicia-se um novo ciclo de desenvolvimento; uma porção da periferia de São Paulo se consolida (pela implantação de serviços públicos e equipamentos de consumo), e o inchaço desregulado se mantém nas regiões de fronteira; e quanto aos ilegalismos, é importante pontuar que as taxas de homicídio em São Paulo reduzem drasticamente, e que o comércio da droga parece se estruturar sobre bases mais estáveis, acarretando menos mortes. ${ }^{104}$

Agora, a partir daqui, deixo as (macro)referências e passo aos percursos.

\section{2 - Pedro}

Pedro nasceu numa cidade pequena do interior do Paraná, em 1974. É o quinto dos sete filhos de um casal de migrantes nordestinos que cruzou o país para trabalhar na lavoura do algodão. Uma terra infértil e geadas constantes jogaram a família na miséria, a tal ponto que se viram novamente obrigados a migrar, dessa vez - em 1978 - para São Paulo, onde Pedro já tinha uma tia vivendo e trabalhando. A família de Pedro foi

\footnotetext{
${ }^{104}$ Para uma discussão acerca de importantes reconfigurações em São Paulo nessas três décadas, relacionando alterações no mundo dos ilegalismos e algumas dessas (macro)referências aqui pontuadas, ver: TELLES (2009c).
} 
recebida por essa tia numa das muitas favelas que se espalhavam pela região da Brasilândia, zona norte da cidade.

Em São Paulo, o pai de Pedro logo arrumou trabalho numa indústria metalúrgica, e alugou um barraco na mesma favela. Seu pai era e sempre foi uma figura carismática. Pedro muitas vezes ouviu dos irmãos mais velhos que, mesmo nos duros tempos do Paraná, o seu pai doava leite para vizinhos necessitados, ajudava famílias com crianças doentes, sempre estava disposto a colaborar, não obstante as dificuldades e doenças na família que ele mesmo enfrentava. Uma vez aclimatado e devidamente instalado na favela, esse aspecto de sua personalidade floresceu, e então, num contexto bastante distinto. Aproximou-se de uma associação de moradores da favela, e rapidamente se destacou com uma de suas lideranças, assumindo, em seguida, a presidência da entidade. Pedro ainda se lembra de quando circulava pela favela acompanhando seu pai, sempre parando de casa em casa, conversando com uns e com outros. Sua casa estava sempre cheia, seu pai era muito procurado pela vizinhança. Aos domingos, o padre da região os ia visitar, faziam novenas de encher o pequeno barraco, e em seguida todos ali permaneciam em acaloradas discussões políticas. Olhando retrospectivamente, Pedro hoje define aquela casa como uma verdadeira Comunidade Eclesial de Base (CEB).

A agitada vida de seu pai refletia a agitação daquele tempo e daquele lugar. Eram tempos de redemocratização. Além de articular-se com os moradores da favela, e com os setores mais progressistas da Igreja Católica - à qual era muito devoto - com o tempo, seu pai articulou-se ainda com o Partido do Movimento Democrático Brasileiro (PMDB), mantendo contato com deputados e vereadores, ora apresentando-lhes a favela e suas demandas, ora apresentando-os à favela como bons candidatos. A irmã de Pedro era operária do setor têxtil, mas inversamente ao pai, fazia política no lugar de trabalho - e não de residência -; era líder sindical na sua fábrica, e participava do processo de construção da Central Única dos Trabalhadores (CUT) e do Partido dos Trabalhadores (PT). Numa tarde de domingo, naquele início de anos 1980, na casa de Pedro reuniamse representantes das principais forças políticas que protagonizavam o processo de redemocratização no Brasil.

Sader (1995) - em "Quando novos personagens entram em cena"- apresenta e discute a relevância dessa miríade de práticas e grupos sociais que, naqueles tempos, redefiniam os horizontes da política brasileira; e que pareciam condensar-se de forma muito intensa 
naquela casa onde Pedro vivia sua primeira infância. Pedro não compreendia os significados históricos daquele momento, nem daqueles eventos, mas tudo lhe era muito marcante e intrigante, desde a barba quase uniforme dos amigos de sua irmã, até um amigo de seu pai, que num dia tomava café na sua sala, e no outro estava na televisão, num palanque repleto de gente. Certamente, toda essa vivência foi fundamental na sua trajetória ulterior. Porém, nem tudo eram flores naqueles anos 1980, e esses outros aspectos da realidade da favela também lhe foram determinantes.

A favela onde crescia ficava, a cada dia, mais violenta; se a figura de seu pai remete a toda aquela agitação política, a de sua mãe remete mais aos perigos que se corria ao brincar na rua. O número de mortes era crescente, e a ameaça vinha de toda parte. Certa vez, empinando pipas com um vizinho, Pedro viu um homem ser friamente assassinado pela polícia, algum tempo depois viu a polícia invadindo casas na vizinhança, prendendo e agredindo pessoas; mais tarde, seu amiguinho foi assassinado pela própria mãe, transtornada pelo álcool e pelas drogas que se propagavam na favela. Motivos não faltavam para que a mãe de Pedro o mantivesse sob rígido controle: brincadeira na rua só se fosse ao alcance de sua vista de mãe, passeios dentro ou fora da favela só acompanhado dos irmãos mais velhos, escola todo dia e boas notas eram obrigações cobradas a custo de surras. Da mesma forma que lhe era normal ver de perto um eminente político, também o era avistar gente morta ou indo presa, apanhando ou dando tiro.

Conforme crescia, via seus amigos de bairro e de escola envolvendo-se com crime e com drogas, alguns desapareciam de repente sem que nunca mais tivesse notícias, outros apareciam mortos num beco, ou em comentários de porta de colégio. Naquele ambiente adverso, além da proteção e rigidez materna, Pedro também desenvolvia suas próprias defesas: foi formando um círculo de amigos que se identificavam pela socialização religiosa, pelo apego à escola, e pelo rechaço radical ao mundo da droga e do crime.

Quando tinha por volta de 10 anos, seu pai ficou desempregado, a situação financeira da família se complicou, e Pedro começou a trabalhar com os irmãos nas feiras da região, carregando sacolas e "olhando" os carros dos consumidores. Nessas ocasiões, viam meninos do mesmo bairro roubando mercadorias e transeuntes, com eles, iam e voltavam juntos, comentavam as façanhas e comparavam os ganhos - os dele, sempre 
inferiores -, de modo que Pedro e seus irmãos poderiam ter enveredado desde muito cedo pelas sendas mais lucrativas da criminalidade. Não quiseram. Com 12 anos, Pedro deixou a feira e começou a trabalhar num supermercado, como empacotador e entregador; com 14, por motivos de saúde, deixou de trabalhar e dedicou-se exclusivamente aos estudos.

Nessa época, o sistema municipal de educação já era administrado por Paulo Freire, secretário da prefeita do PT, Luisa Erundina. Nas aulas de $\operatorname{OSPB}^{105}$, finalmente entendeu e se encantou pelos ideais socialistas que sua irmã tanto falava, convertendose ao petismo. Aproximou-se do núcleo do PT de sua região e se envolveu nas disputas eleitorais, e de maneira especial na campanha presidencial de Lula, em 1989. Ao mesmo tempo, tornou-se assíduo freqüentador das atividades da Igreja Católica voltadas para a juventude, participando de retiros e de outros eventos no bairro. Seria de se pensar que essa mudança de atitude provocasse orgulho e alegria naquela família tão afeita à religião e à militância. Porém, não foi assim que as coisas se passaram. O engajamento efetivo de Pedro na política e na religião se deu no exato momento em que sua família praticamente inteira se convertia ao protestantismo, e abandonava qualquer atividade política. O desemprego prolongado, a substituição do pároco (por um menos presente e ativo) e o desaparecimento do PMDB do bairro magoaram sobremaneira o pai de Pedro, afundando-o num alcoolismo do qual só saiu pela conversão evangélica - para a qual levou boa parte da família. É certo que se os pais e irmãos não se entusiasmavam com as novas atividades de Pedro, tampouco o desestimulavam, já que conheciam os meandros do catolicismo politizado e consideravam melhor aquilo do que a rendição ao crime e à droga, que só faziam aumentar na favela.

No começo dos anos 1990, Pedro voltou a trabalhar. Tornou-se vendedor numa loja de peças de automóveis. Também foi estudar o ensino secundário noturno numa escola que ficava fora da favela. Ali ampliou ainda mais sua rede de contatos e de referências, tendo despertado o sonho de cursar uma universidade pública - tanto pelos incentivos do novo patrão, quanto pelas conversas com os novos colegas e professores. Em 1992, no campo da política nacional foi um dos "caras-pintadas" a lutar pelo impeachment do presidente; e no da política local, envolveu-se com a Pastoral da Moradia. Aproximavase um momento de grandes definições na sua vida. Sentia progressiva aversão à política

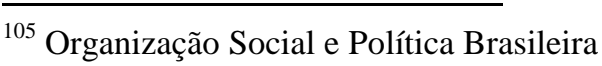


partidária, conforme a ia conhecendo melhor; interessava-se cada vez mais pelas atividades políticas religiosas da pastoral, de tal forma que chegava a vislumbrar a possibilidade de integrar-se aos quadros da Igreja; e, ao mesmo tempo, almejava alcançar o ensino superior. Como é normal a essa altura da vida, Pedro tinha muitas dúvidas e ambições. Com esse ânimo, procurou aconselhamento com aquele padre dos tempos de outrora, que o vira crescer nas reuniões e novenas da "CEB" daquela favela na Brasilândia, e para quem Pedro guardava um grande apreço. O padre, muito feliz em atendê-lo depois de tanto tempo, e mais ainda pela ordem de questões que os reuniam novamente, foi sábio e prático: aconselhou-o a estudar direito penal, para que pudesse ajudá-lo na Pastoral Carcerária - onde então ele estava atuando -; se no decorrer do curso universitário, o interesse na vida religiosa se confirmasse, depois tratariam do tema. E foi o que Pedro fez. Formou-se no ensino secundário, ingressou num cursinho popular, e estudou muito até entrar no curso de direito da Universidade Estadual Paulista (UNESP) de Franca, em 1995.

E é nesse ponto, a meados da década de 1990, que o percurso de Pedro se cruzou com a trajetória do sistema penitenciário paulista, pela via da Pastoral Carcerária. Mas o que seria essa entidade gravitando o sistema prisional, naquele momento? Para melhor situála cabe uma breve digressão, que remonta àquele agitado final da década de 1970.

\section{3 - Gravitações}

Naquele mesmo ano de 1978, em que a família de Pedro chegou a São Paulo, foram criados os primeiros Comitês Brasileiros de Anistia em diferentes capitais do país. ${ }^{106}$ Esses comitês agregavam além de artistas, intelectuais e estudantes opositores ao regime militar, familiares e amigos de presos políticos e os mesmos setores do MDB e da Igreja Católica que, àquela altura, apoiavam e aglutinavam os movimentos sociais em torno de outras questões, nas diversas fábricas e favelas espalhadas pelos centros urbanos. Em dezembro do mesmo ano, São Paulo sediou o Primeiro Congresso Nacional de Anistia,

\footnotetext{
${ }^{106}$ As informações sobre o movimento de anistia estão em: COSTA (2001).
} 
reunindo os comitês de todo o país e estabelecendo a reivindicação por "Anistia ampla, geral e irrestrita”. No biênio 1978-1979, várias manifestações públicas tomaram as ruas de diferentes cidades, denunciando as injustiças correntes no sistema prisional e reivindicando a libertação dos presos políticos. Ao mesmo tempo em que a sociedade civil ia para as ruas, um grupo de parlamentares, principalmente do MDB, articulados pelo senador Teotônio Vilela, percorreu o Brasil visitando presídios e presos políticos, fazendo um levantamento das condições de tratamento penitenciário a que estavam submetidos. A repercussão do movimento nas ruas e da atividade da Comissão Parlamentar (dentro e fora do Congresso) foi tão grande, que o recém empossado presidente, o General João Batista Figueiredo, já admitia a possibilidade de indultar os presos políticos. Uma proposta de Lei de Anistia parcial foi encaminhada pelo presidente e rechaçada pelo movimento e pelos parlamentares da Comissão. Vislumbrando a possibilidade de avanço, um grupo de presos políticos do Rio de Janeiro, em julho de 1979, iniciou uma greve de fome pela anistia, que durou 32 dias. ${ }^{107}$ Em agosto de 1979, o presidente encaminhou nova proposta de lei, dessa vez aprovada e promulgada no dia 28 daquele mesmo mês.

Eis uma síntese por demais esquemática de um marco fundamental no processo de redemocratização do Brasil. Não seria o caso de avaliar aqui se a lei correspondia às demandas por anistia ampla, geral e irrestrita; ou se ela foi um artifício tático para isentar os militares, os torturadores e os assassinos a serviço do estado de suas responsabilidades criminais. Aqui só interessa assinalar que esse movimento foi um fundamental impulso de estruturação de grupos, entidades e organizações civis em torno da questão prisional, desde o início do período ditatorial, que legou para a década seguinte uma forte herança organizativa. No começo da década de 1980, algumas organizações que participaram daquele movimento se converteram e outras se estruturaram em torno da questão dos direitos humanos, que não obstante sua amplitude de foco, contemplavam a questão do tratamento desumano dispensado nos sistemas penitenciários do Brasil aos presos comuns.

Em janeiro de 1982, no Centro de Estudos Franciscanos e Pastorais para a América Latina (CEFEPAL), em Petrópolis, no estado do Rio de Janeiro, aconteceu o Primeiro

\footnotetext{
${ }^{107}$ Segundo Costa (2001), greves de fome eram práticas comuns e recorrentes dos presos políticos, mas essa, em especial, teve um peso enorme, pela conjuntura que a colocava em destaque.
} 
Encontro Nacional de Direitos Humanos, que reuniu 33 entidades, de 11 estados, das regiões Norte, Nordeste, Sudeste e Sul do país. ${ }^{108}$ Os diversos centros de defesa dos direitos humanos, comissões "Justiça e Paz”, comissões diocesanas, comissões pastorais de diferentes municípios brasileiros fundaram então o Movimento Nacional de Direitos Humanos. O caráter político-religioso da formação desse movimento é evidente. ${ }^{109}$

Ainda em 1982, alguns dos intelectuais e parlamentares protagonistas do movimento por anistia, articulados pelo senador Severo Gomes (PMDB), uniram-se numa comissão para investigar um incêndio no Manicômio Judiciário de Franco da Rocha, que vitimara seis internos. O grupo estendeu suas atividades para outras instituições fechadas em São Paulo e Rio de Janeiro, sendo formalizado em 1983, sob a alcunha de Comissão Teotônio Vilela (CTV), em explícita homenagem ao parlamentar que liderou o movimento por anistia no Congresso Nacional - e que era membro fundador da mesma. ${ }^{110}$ Em 1986, a Conferência Nacional dos Bispos do Brasil (CNBB) fez a primeira reunião nacional da Pastoral Carcerária, formalizando e organizando suas atividades no território nacional. ${ }^{111}$ Em 1988, com a chegada na coordenação da entidade daquele pároco que atuava na Brasilândia no começo da década, a Pastoral Carcerária tem seu primeiro grande impulso, passando a ter ampla capilaridade no território nacional, e projeção e articulação com entidades de defesa dos direitos humanos do exterior. Em 1987, em São Paulo, formalizou-se o Tortura Nunca Mais, um coletivo de defensores dos direitos humanos, ex-presos políticos e familiares de mortos e desaparecidos - muitos que haviam participado da produção e publicação do histórico documento "Brasil: nunca mais" (PROJETO BRASIL NUNCA MAIS, 1985) - para denunciar e combater as práticas de tortura do passado e do presente. E também em 1987, agentes da CTV, em especial, o professor de ciência política da Universidade de São Paulo (USP), Paulo Sérgio Pinheiro, em conjunto com o professor de sociologia da mesma faculdade, Sérgio Adorno, criaram o Núcleo de Estudos da Violência (NEV),

\footnotetext{
${ }^{108}$ Ver: RELATÓRIO DO I ENCONTRO NACIONAL DE DIREITOS HUMANOS (1982).

${ }^{109}$ Só para exemplificar a importância de setores progressistas da Igreja Católica na estruturação do movimento, vale a citação do seguinte excerto do relatório: "Relações com a hierarquia eclesiástica local: A quase totalidade dos grupos presentes mantém boas relações com os seus respectivos bispos. Apesar de serem organismos autônomos (no caso dos CDDHs) são apoiados em suas lutas com grande liberdade de atuação. As CJP estão profundamente ligadas à cúria local tendo estas a participação mais definida dos bispos. O mesmo acontece com a IECLB. Infelizmente existem ainda exceções." (Idem, 1982, p.1)

${ }^{110}$ Informações disponíveis em www.nevusp.org e www.ctvdh.org (Consulta feita em maio de 2010).

${ }^{111}$ Informação disponível em: http://www.carceraria.org.br/default2.asp?pg=sys/nucleo\&cat_cod=2418 (Consulta feita em maio de 2010)
} 
nos moldes do Center for the Study of Human Rights, da Universidade de Columbia. O objetivo era desenvolver projetos de pesquisa paralelos à atuação da CTV, que pudessem subsidiar suas intervenções, as de outras organizações, bem como políticas públicas.

Eis não mais do que alguns marcos fundamentais da estruturação de um campo de agentes, práticas e discursos em torno da questão prisional na década de 1980. A enunciação de tais marcos não tem a pretensão de oferecer uma visão abrangente (ou totalizadora) sobre esse processo de estruturação, que seguramente envolve outros agentes, entidades e episódios de igual relevância. A sua seleção tão somente objetiva demarcar alguns aspectos que podem ser considerados constitutivos desse campo naquela década, quais sejam: 1 - uma importantíssima presença de setores progressistas da Igreja Católica em todos os níveis do campo; 2 - uma pauta fortemente vinculada às violações e arbitrariedades do período ditatorial (a questão da tortura, dos mortos e desaparecidos políticos, da violência abusiva de agentes estatais, etc.); e 3 - a emergência de uma inteligentsia que sistematiza, produz e divulga conhecimento sobre as violações e arbitrariedades, passadas e presentes, formula programas de intervenção e se articula internacionalmente.

Já em 1983 - primeiro ano de gestão do governador eleito Franco Montoro - a nomeação para a Secretaria da Justiça do ex-presidente da Comissão Justiça e Paz da Arquidiocese de São Paulo, o advogado José Carlos Dias, e seus esforços de humanização dos presídios, representam uma primeira aproximação desse campo político às estruturas do poder estatal. Porém, como indica o fracasso da política de humanização no sistema prisional - e de forma análoga ao que se passava na mesma década naquela favela da Brasilândia - nem tudo eram flores na estruturação desse campo.

Caldeira (1991) - em "Direitos humanos ou 'privilégios de bandidos'?” - problematiza duas questões fundamentais para se compreender o processo de estruturação dessa rede de agentes e entidades, principalmente, no contexto paulista. Em primeiro lugar, discute o movimento - suas causas e circunstâncias - de dissociação da pauta dos direitos humanos daquele escopo mais amplo de direitos fundamentais, consagrados pelos novos movimentos sociais analisados por Sader (1986), e sua progressiva associação ao universo mais restrito dos direitos civis dos presos comuns. Em segundo lugar, a partir 
dessa nova configuração, a autora discute a resistência, a oposição e a aversão que a pauta dos direitos humanos progressivamente passou a inspirar em amplos setores da sociedade. Segundo a autora:

"deve-se mencionar que a campanha em defesa dos direitos humanos para prisioneiros comuns, bem como a sua contestação, articularam-se publicamente no momento em que a cidade de São Paulo apresentou seus maiores índices de criminalidade violenta das últimas duas décadas, ou seja, durante o período 1983-1985. Esses foram os dois primeiros anos do governo Montoro e, portanto, da tentativa de humanização dos presídios e de reforma da polícia. Nesse contexto, o medo e a insegurança foram manipulados com facilidade pelos opositores à defesa de direitos humanos, ao mesmo tempo em que, sutilmente, a criminalidade foi sendo associada a práticas democráticas." (CALDEIRA, 1991, p.164)

Portanto, no decorrer da década de 1980 e na primeira metade da década de 1990, a gravitação de agentes, práticas e discursos em torno da questão prisional, se dava no embate de dois campos distintos, um favorável a políticas de realização de direitos humanos nos presídios, e outro que fazia campanha contrária, afirmando: 1 - a "monstruosidade" dos criminosos; 2 - que o reconhecimento dos direitos dos presos significaria concessão de privilégios imerecidos em detrimento dos "cidadãos de bem"; e 3 - que o aumento da criminalidade exigiria medidas penais e de controle do delito cada vez mais duras. Como se pode observar, a esse segundo campo correspondem os agentes, práticas e discursos próprios do populismo penal brasileiro.

O populismo penal no Brasil conforma toda uma linhagem política de alto desempenho eleitoral e, desde a redemocratização, sempre presente nas principais casas legislativas federais, estaduais e municipais. Personagens como Erasmo Dias ${ }^{112}$, Afanázio Jazadji $^{113}$, Conte Lopes ${ }^{114}$ e Coronel Ubiratan $^{115}$ foram diversas vezes eleitos

\footnotetext{
${ }^{112}$ Militar articulador do golpe de 1964, foi designado secretário de Segurança Pública de São Paulo. Entre 1978 e 2004 exerceu seguidos mandatos de deputado federal, deputado estadual e vereador.

${ }^{113}$ Radialista reconhecido por seus programas policiais, desde 1986 exerceu cinco mandatos de deputado estadual.

${ }^{114}$ Policial militar das Rondas Ostensivas Tobias de Aguiar (ROTA), desde 1986 exerceu seguidos mandatos de deputado estadual.

${ }^{115}$ Policial militar que ganhou notoriedade por comandar a operação que resultou no Massacre do Carandiru, desde 1997 exerceu seguidos mandatos de deputado estadual. Foi encontrado morto em sua residência em setembro de 2006.
} 
democraticamente através de um discurso calcado em críticas ferozes aos defensores de direitos humanos, no clamor pelo endurecimento penal e pelo combate à criminalidade a qualquer custo. ${ }^{116}$

Esse campo de disputa política, não obstante remeta a questões mais gerais e a outros dispositivos de poder, também compõe o dispositivo carcerário em São Paulo, e nos seus embates práticos e discursivos, diretos e mediados, a própria estruturação desse dispositivo entra em jogo. Um campo, favorável ao tratamento cada vez mais duro no interior dos presídios, focava sua atuação na expansão e fortalecimento do aparato policial ("Rota na rua"), e incidia incisivamente no arcabouço legislativo através de seus mandatos. $\mathrm{O}$ outro - resistindo à estigmatização que lhe era imposta - tematizava os problemas da superlotação, da precariedade institucional, e atuava mais próximo do sistema prisional, fiscalizando e denunciando violações de direitos pontuais e concretas, e acessando os novos expedientes jurídicos forjados no processo de redemocratização.

No primeiro governo do presidente Fernando Henrique Cardoso, o conjunto de agentes favorável aos direitos humanos começou a romper o isolamento e a se reaproximar das mais altas esferas estatais, envolvendo-se ativamente na elaboração do primeiro Programa Nacional de Direitos Humanos, lançado pelo governo federal em 1996. Nesse processo, o NEV desempenhou papel estratégico, abrindo a possibilidade de intervenção e elaboração para os outros agentes que compunham o campo. ${ }^{117}$ A partir daí, o diálogo entre Estado e diversas entidades defensoras dos direitos humanos se rotiniza em conferências anuais.

É nesse contexto que Pedro começa a atuar na Pastoral Carcerária e a freqüentar os presídios paulistas. Até aqui foram esquematicamente apresentadas a conjuntura, as articulações e a disputa política em que atuava a entidade que o introduziu no sistema carcerário. Antes de passar a sua experiência direta na pastoral, cabe melhor apresentar o que encontrava quando entrava (e saía) da prisão representando a entidade, ou seja, o que vinha se passando, já não na esfera exterior - gravitacional - do dispositivo, mas

\footnotetext{
${ }^{116}$ Para uma análise de seus discursos e trajetórias políticas desde os tempos da ditadura militar, até suas atuações parlamentares, ver: SILVA (2004).

${ }^{117}$ Paulo Sérgio Pinheiro foi o relator do primeiro e segundo programas, tendo o NEV estabelecido um convênio de assessoria com a Coordenadoria do Plano Nacional de Direitos Humanos, do Ministério da Justiça. Para uma apresentação mais detalhada e analítica desse processo, ver: PINHEIRO e MESQUITA NETO (1997), e MESQUITA NETO (1997).
} 
nas suas dimensões interiores, subterrâneas, tectônicas. E para tanto, recorro à trajetória de outro interlocutor da pesquisa.

\section{4 - Amaro}

Amaro nasceu em 1961, numa cidade do agreste pernambucano. Viveu num sítio modesto com os pais e mais sete irmãos até os nove anos de idade, quando seu pai arrendou as terras para um parente e todos vieram para São Paulo. O pai conseguiu emprego rapidamente, sendo contratado pela prefeitura para abrir as valas que levariam o saneamento básico para os crescentes bairros periféricos da cidade. A mãe arrumou uma vaga como costureira numa fábrica do Brás. E Amaro começou a trabalhar vendendo doces e sorvetes nas ruas do bairro. Quando ficou bastante conhecido chegava a ganhar mais do que seu pai. Só aos 13 anos de idade Amaro começou a estudar numa escola pública da região.

Os anos foram passando e o pai de Amaro virou porteiro no fórum da Praça João Mendes, no centro. Ali conseguiu arrumar uma vaga para Amaro, que já estava com 16 anos e não queria mais vender sorvetes. Em 1977, Amaro começou a trabalhar no fórum como office boy interno, trazendo e levando papéis pelos muitos andares do prédio. Ali se familiarizou com os trâmites da justiça, com a formalidade na apresentação e com a estabilidade do funcionalismo público. Porém, completando 21 anos o seu desligamento era automático. Se quisesse seguir trabalhando no fórum teria que prestar concurso.

Em 1982, um amigo que era protético convidou Amaro para trabalhar com ele. Seu serviço era buscar e entregar encomendas, fazer cobranças, e nos períodos de menor movimento, arriscava esculpir algumas peças. Após dois anos, Amaro pediu demissão e resolveu montar o seu próprio laboratório de próteses, em outro canto do mesmo bairro. Alugou uma sala em sociedade com um dentista, fez cursos no sindicato dos protéticos, investiu suas economias em equipamento e começou a trabalhar por conta própria. Porém, sua experiência como autônomo não durou muito tempo: o dentista que era seu sócio lhe aplicou um golpe, roubando num final de semana todos os equipamentos mais 
valiosos do seu laboratório e desaparecendo em seguida. Assim Amaro abandonou de vez o ramo das próteses dentárias.

Corria o ano de 1984, e Amaro pensava na possibilidade de estudar e prestar concursos para alcançar novamente a estabilidade do funcionalismo público. Além do fracasso no laboratório, outro motivo o levava a pensar nessa alternativa: a gravidez de sua namorada. Depois de muito estudar, em 1985, Amaro prestou dois concursos, um para a Secretaria de Administração do Estado (SAE), outro para a Secretaria de Justiça (SJ), e foi aprovado em ambos. Foi chamado primeiro pela SAE, mas dispensou a vaga, pensando na remuneração significativamente mais alta do outro cargo, que contava com adicionais de trabalho noturno e periculosidade. Amaro seria agente penitenciário.

Amaro foi chamado para trabalhar em 1986. No fim do ano, participou de um curso de 45 dias, que foi ministrado num anexo do presídio de Samaritá, no interior do estado. O treinamento era todo administrado por militares e policiais civis que atuaram nos órgãos de repressão da ditadura. Amaro rastejou na lama, dormiu no chão, passou fome, e realizou uma série de outras atividades que considerava abusivas e despropositadas. Além dos "exercícios" práticos, escutava palestras sobre criminalística, direito e processo penal, direito administrativo, etc. Tinha também instruções regulares de defesa pessoal e de "disciplina", para aprender a como ser rígido no tratamento com os reclusos. Porém, o curso não foi tão determinante na formação de Amaro, que logo percebeu que uma qualificação como aquela não podia deixar de ser superficial, uma vez que o mais importante aprendizado começa no momento em que o funcionário entra numa unidade real e respira a atmosfera do ambiente.

Amaro trabalhou de 1987 a 1989 numa penitenciária do litoral paulista; de 1989 a 1990 na Casa de Detenção de São Paulo; no presídio do Hipódromo, de 1990 até seu fechamento em 1995; e na Penitenciária do Estado, de 1995 a 2001. Durante toda a sua trajetória profissional as condições de trabalho foram as piores possíveis. Se - como foi apontado no marco zero dessa cartografia - a precariedade institucional é um elemento constitutivo do aparato penitenciário paulista, ela não se restringe às péssimas condições de vida para os detentos, atingindo também, por extensão, as condições de trabalho de seus funcionários. 
Num ambiente prisional extremamente deteriorado, as funções de segurança do agente penitenciário ultrapassavam em muito o abrir e fechar das grades, o controlar as movimentações, o vigiar os detentos. Sob essas condições, o trabalho do agente não se fazia de uma torre de vigilância, à distância; mas sim, no próprio corredor, no pátio, em trânsito, e tudo isso, muito perto dos detentos, em meio a eles e de seus entreveros. As atividades cotidianas do agente penitenciário muito pouco lembravam os protocolos estabelecidos formalmente no edital do concurso público. No edital não se mencionava o carregar corpos inertes, perfurados dezenas de vezes; nem se falava em castigar um preso que se declara homicida com um pedaço de pau ou de aço; nem em mobilizar informantes estratégicos para se antecipar a tentativas de fuga, de homicídios, de rebeliões, etc. - atividades que pontuaram o cotidiano profissional de Amaro.

Não seria demasiado afirmar que, da precariedade institucional, erigia-se um mundo social no limiar da vida e da morte. Principalmente até meados dos anos 1990, morrer e matar eram, efetivamente, possibilidades muito concretas para qualquer detento, e ao agente penitenciário cabia também operar a gestão dessa violência interna exacerbada, muitas vezes por meio da própria violência, outras vezes, por meio da inteligência. A morte violenta ocupava o centro do dispositivo, estruturava práticas de detentos e agentes penitenciários, conformava o que poderia ser visto como protocolos informais da gestão da prisão, uma gestão que - pela mesma precariedade institucional - nunca esteve inteiramente na mão dos funcionários, sendo sempre o resultado provisório e instável de múltiplas negociações entre os diversos agentes que compõem a instituição. Em suma, ao invés de desenvolver programas regeneradores, enquanto Amaro trabalhou no sistema prisional paulista, gerir uma prisão era o mesmo que gerir a violência que imperava na prisão, e isso sem poder abrir mão de uma negociação continuada com os detentos, seja com suas lideranças mais eminentes, com os presos mais comuns ou com os informantes mais discretos. Pelo relato dos expedientes de trabalho de Amaro em diferentes ocasiões, é possível vislumbrar como a iminência da morte estruturava suas práticas.

Trabalhando na "inclusão"118, Amaro investigava se o recém-chegado teria inimigos na prisão, se os tivesse a possibilidade que ele fosse assassinado logo nos primeiros dias era realmente grande. Fazia então um interrogatório com o preso, e ainda o mantinha

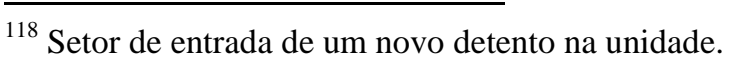


por alguns dias no setor de "inclusão", até que corresse entre os detentos a informação de que aquele preso estava ali. Se houvesse um desafeto dele na prisão, uma ameaça de morte logo viria, e, portanto, Amaro o encaminharia direto para o "seguro" ". Se depois de alguns dias o recém-chegado não fosse ameaçado, ou se fosse até "festejado" por alguns presos, Amaro liberava-o para o "convívio" ". Quando trabalhava num pavilhão esse tipo de gestão se desdobrava, já que rivalidades e desafetos eram continuamente produzidos no ambiente prisional. Então, Amaro continuamente fazia operações de "trânsito"121, encaminhando uma vítima potencial para o "seguro", ou quando não havia tido tempo para evitar o homicídio, Amaro tinha que encaminhar o "laranja"122 que assumia o delito (quase sempre de autoria múltipla) para o "castigo" 123 . Quando ficava no setor de revistas de "jumbo" e visitantes, Amaro tinha que prestar especial atenção em artefatos que poderiam ser convertidos em armas brancas; e quando realizava revistas (ou blitzes) em celas, as armas eram sempre seu objetivo prioritário. Nas blitzes, uma equipe de funcionários removia todos os presos da cela (geralmente com um grau de violência procedimental), as coisas deles eram todas reviradas (quando não destruídas), e Amaro era um dos que mais faro tinha para, nessas ocasiões, descobrir esconderijos de facas.

Cada uma dessas operações envolvia um alto grau de complexidade e destreza da parte dos funcionários. Segundo Amaro, as habilidades necessárias ao agente penitenciário eram irredutíveis a uma técnica que pudesse ser escolarmente transmitida; tratava-se mais de conhecimentos práticos até difíceis de verbalizar sem fazer referência às situações concretas em que foram exigidos.

Amaro relata uma série de casos: como descobriu uma vítima potencial, como soube qual cela revistar e quando era o melhor momento para fazê-lo, como saber qual pacote ou visitante tinha que receber uma revista mais rigorosa, etc. Para desencadear todas essas práticas o mais importante era a informação que se recebia, até porque, pela precariedade das condições de trabalho, era muito difícil que um funcionário pudesse

\footnotetext{
${ }^{119}$ Setor para ameaçados de morte, para uma discussão mais aprofundada desse ponto estratégico do dispositivo carcerário, ver: MARQUES (2009).

${ }^{120}$ Setor de cumprimento de pena em condições "normais", para uma discussão mais aprofundada, também ver: MARQUES (2009)

${ }^{121}$ Todo tipo de movimentação de internos no sistema prisional.

${ }^{122}$ Preso que assume um delito ou falta alheia para pagar dívidas ou obter regalias. Para uma breve e precisa descrição dessa recorrente personagem prisional, ver: VARELLA (1999) pp. 148-149.

${ }^{123}$ Lugar de sobre-confinamento punitivo, antiga "solitária", mas que também podia ser coletiva.
} 
evitar um homicídio no ato, ou que revistasse todas as celas, visitantes e "jumbos" com igual dedicação. Ao invés de protocolos racionalizados e universais de tratamento, o que era operante nas prisões paulistas era uma espécie de arte da antecipação. Uma gestão artesanal da informação que circulava no presídio, através da discreta manutenção de uma rede de detentos informantes. Apesar do risco que a atividade envolvia, Amaro conta que não faltavam presos que se prestassem ao serviço. Podiam informar por vingança, por interesse ou por altruísmo (para preservar a tranqüilidade da prisão); independentemente dos motivos que a impulsionavam, a informação corria. Avaliar a qualidade da informação também era um desafio, o qual tinha de ser superado antes que ocorresse o pior ou se prejudicasse um inocente. Por contraste de fontes e por outras modalidades de investigação, as informações que chegavam deviam ser prontamente checadas. Por isso, cada funcionário mantinha sua própria rede de informantes, de variadas qualidades, inserções e níveis de confiabilidade. A transmissão da informação se dava na maior discrição, para não expor o informante aos presos - o que inevitavelmente acarretaria a sua morte, e a perda da fonte -, nem para outros funcionários - já que sempre existia a possibilidade de "contra-informação" (de um funcionário corrompido informar certas coisas a um preso).

Esse é o solo de práticas e problemas que tanto presos como funcionários tinham que lidar. É nessa complexa trama de relações urdidas a partir da precariedade e da morte, que Pedro, como agente pastoral, também foi se inserir na metade dos anos 1990. Porém, nesse momento específico, esse solo vinha sofrendo alguns abalos. Alguns deslocamentos importantes já estavam em curso nas camadas tectônicas do dispositivo, e eles também devem ser pontuados nessa cartografia.

\section{5 - Tectônicas}

No decorrer da década de 1990, o dispositivo carcerário paulista sofreu um processo de profunda reestruturação, que foi pautado pela emergência e consolidação do Primeiro Comando da Capital (PCC), dentro e fora das prisões paulistas. Fundado em 1993, no Anexo da Casa de Custódia e Tratamento de Taubaté, a organização de presos 
rapidamente ganhou força, e foi impondo (pela violência ou convencimento) sua hegemonia em diversos presídios do estado de São Paulo (e não só dele). Tão rapidamente quanto se hegemonizava no interior do sistema prisional, o PCC ganhava também capilaridade nas ruas. ${ }^{124}$ Num primeiro momento de seu desenvolvimento, ainda silenciado, organizava ações - principalmente rebeliões - que permaneciam anônimas. Com o tempo, e a diversificação de suas práticas, seu nome começou a circular, e toda uma disputa sobre a sua "verdade" entrou no foco do dispositivo: o PCC existe ou não existe? É forte ou fraco? É o "partido dos presos" ou o "sindicato do crime"? É o “crime organizado", o "tráfico de drogas" ou um "código moral”, um “conjunto de práticas", ou mesmo, um "foco de resistência”? Sem condições, nem pretensões de responder a esses questionamentos, aqui cabe tão somente apontar para a emergência dessa nova força, chamada PCC, como peça fundamental no interior do dispositivo. Emergência que é discursiva e também prática. No mesmo ritmo em que se intensificava o debate sobre a sua "verdade", seu repertório de ações seguia se diversificando, e sua presença exterior à prisão se consolidando. O PCC representaria um verdadeiro abalo sísmico no dispositivo, diante do qual nenhum agente, prática ou discurso articulado nessa rede carcerária poderia ficar alheio.

Ainda no Hipódromo, Amaro ouviu boatos sobre a existência desse coletivo de presos, mas através de sua rede de informantes não chegou a ficar sabendo da sua presença naquele presídio. Só depois de duas rebeliões consecutivas, que selaram o destino do Hipódromo - a sua desativação - ouviu dizer que ambos os motins haviam sido "ordenados" (ou perpetrados) pelo PCC. Quando começou a trabalhar na Penitenciária do Estado, no final de 1995, o PCC ali já era uma realidade estabelecida, que vinha transformando todo o solo de práticas possíveis na gestão do cotidiano (e da violência) prisional. Para Amaro, o estabelecimento de uma rede de informantes tornava-se mais e mais difícil, toda vez que se aproximava de um detento era evitado, as conversas se tornavam mais distantes, formais e breves. Quase nunca se encontrava sozinho com um preso, numa situação em que pudessem negociar informações e benefícios, os presos só se dirigiam aos funcionários acompanhados de testemunhas, e cada vez mais eram

\footnotetext{
${ }^{124}$ Com base em pesquisa documental, elaborei uma cronologia sintética do PCC, ver: GODOI (2009d)
} 
sempre os mesmos "faxinas"125 que tomavam a tarefa de comunicar eventos, demandas e situações para o corpo de funcionários. Nas vezes em que Amaro, a muito custo, estava prestes a recrutar um preso insatisfeito com determinada situação ou liderança do pavilhão, antes que o vínculo se formasse, e por razões que ele desconhecia, esse preso aparecia ou morto numa cela, ou espancado no pátio, ou era enviado ao "seguro" a pedido do próprio "faxina". Amaro sentia que, diante do PCC, o seu poder de ação se reduzia em muito, de modo que a gestão compartilhada do ambiente prisional - que sempre caracterizou o funcionamento dos presídios paulistas - já se dava em outra escala. Muitas das informações que mobilizavam ações estratégicas não passavam por ele, mas por funcionários que ocupavam posições mais altas na hierarquia, e que mantinham conversas mais "francas" com as lideranças de um pavilhão. Anteriormente, Amaro se apoiava na multiplicidade de conflitos e rivalidades entre os presos, para levantar informações e assim apreender armas, drogas, evitar mortes e fugas. Na Penitenciária do Estado, os presos pareciam agir de forma mais coordenada, e a informação já não corria da mesma forma, nem pelas mesmas vias.

Além disso, a possibilidade de rebelião estava sempre presente. Ainda que naquele presídio Amaro tenha tido a felicidade de não presenciar nenhuma rebelião, as rebeliões nos cárceres paulistas tornavam-se recorrentes, e, no meio dos funcionários, as histórias corriam como rastro de pólvora, apavorando a todos.

Dois episódios limites - um dentro e outro fora da penitenciária - expressam bem a perda de poder que um funcionário como Amaro estava enfrentando no sistema carcerário, a partir da emergência do PCC. Se antes Amaro sentia que muitas vezes a vida de um detento dependia de sua capacidade de colher informações e encaminhar "trânsitos" às pressas, na Penitenciária do Estado, na segunda metade da década de 1990, ao contrário, Amaro ia percebendo que era a sua vida que dependia da intervenção rápida de presos influentes. E isso não era sem motivo. Num sábado qualquer, o agente penitenciário caminhava sozinho por um dos pavilhões e foi surpreendido por cinco presos armados que estavam cobertos de lama. Claramente eles estavam cavando um túnel para fugir e pensaram que Amaro vinha para impedi-los. Amaro tentou correr, mas não houve tempo, o agente penitenciário que cuidava da

\footnotetext{
${ }^{125}$ Presos responsáveis por determinadas funções, como distribuição dos alimentos e limpeza dos pavilhões. Desempenhavam um papel importante também na organização interna dos presos, para uma bela descrição de suas características e atribuições, ver: VARELLA (1999), pp.99-103.
} 
entrada do pavilhão o trancou com os presos, seguindo os protocolos determinados pela diretoria para impedir fugas. Amaro foi feito refém e o ameaçavam de morte. Tomado pelo medo, Amaro tentava se explicar, dizendo que não sabia de nenhuma tentativa de fuga e que sua intenção não era e nem podia ser surpreendê-los em flagrante sozinho. Enquanto Amaro tentava se explicar, uma das lideranças do PCC pediu para que o agente que lacrara o pavilhão com Amaro dentro, o abrisse para que ele entrasse. $\mathrm{O}$ agente abriu a porta, contrariando os protocolos da direção, mas esperançoso de que aquela autoridade da massa carcerária pudesse intervir no sentido de preservar a vida do colega de trabalho. E foi o que realmente aconteceu. A liderança disse aos presos enlameados que se o plano de fuga havia sido descoberto seria pela falha de seus próprios executores, não pela intervenção de um único agente penitenciário; disse também que naquele dia ninguém estava autorizado a matar ninguém no presídio, pois era véspera de dia de visita, e qualquer incidente na unidade seria suficiente para que nenhuma visita entrasse. Desse modo, os presos jogaram as facas no chão e desistiram de matar Amaro. O PCC lhe salvara a vida.

Porém, as relações de Amaro com a facção prisional paulista não seriam sempre tão “positivas". É isso que se deduz do segundo episódio limite, que efetivamente marca o fim da trajetória de Amaro no interior do sistema prisional. Com o tempo, Amaro ia aprimorando o seu conhecimento sobre as instalações da penitenciária, e, conseqüentemente, aumentando o número de apreensões de drogas, facas e telefones celulares nas revistas que realizava. Em 2000, Amaro chefiou uma revista que resultou na apreensão de dezenas de facas, desarticulando um "acerto de contas" massivo que vinha sendo planejado há meses. Se até esse momento, Amaro conseguia manter uma relação tênue de respeito mútuo com as lideranças da massa carcerária, depois disso, esse tenso equilíbrio foi quebrado. Dias depois da revista, Amaro estava brincando com seu filho caçula na porta de sua casa, quando recebeu uma mensagem vinda da prisão. Um grupo de pessoas que Amaro nunca havia visto na vida parou dentro de um carro diante de sua casa e lhe chamou para conversar. Ao se aproximar, Amaro viu que estavam todos eles armados. Em tom respeitoso, o homem que estava no banco de passageiro lhe disse que tinha um recado da penitenciária, disse que os presos estavam descontentes e intrigados com Amaro, que encontrava muitas coisas e atrapalhava os planos da organização, recomendaram-lhe que ficasse mais afastado dos problemas 
entre os presos, que deixasse que eles resolvessem suas questões da forma que lhes parecesse mais adequada e que desse modo ficaria tudo bem para todos. Amaro entendeu o recado como uma ameaça de morte, a ele e a toda a sua família. Depois disso, Amaro pediu férias, e nunca mais voltou para o presídio. Tanto que foi num balcão de bar que Amaro viu, consternado, a Penitenciária do Estado servir de epicentro da maior rebelião prisional conhecida até então. ${ }^{126}$

Pedro, por sua vez, por estar entrando no sistema prisional, tinha menor sensibilidade para perceber as movimentações subterrâneas do dispositivo. Assim que começou a cursar a faculdade de direito, em 1996, Pedro integrou-se à unidade da Pastoral Carcerária de Franca, começando a realizar visitas às unidades prisionais da região. Acompanhava de longe os avanços na política nacional de direitos humanos, e focava suas atividades nos presídios locais. No começo, integrado ao grupo reduzido da pastoral, ele prestava somente assistência religiosa. Depois de 1997, quando a CNBB promoveu uma Campanha da Fraternidade com o tema "A fraternidade e os encarcerados", sob o lema "Cristo liberta de todas as prisões" ${ }^{127}$, a Pastoral Carcerária passou a atrair um número muito maior de interessados em todo o Brasil. Em Franca, a expansão dos quadros pastorais permitiu que Pedro transformasse em alguns aspectos a linha de atuação da entidade. Além da assistência religiosa e das denúncias pontuais de casos de violações de direitos e maus-tratos, Pedro articulou, na faculdade e com alguns novos integrantes da pastoral, um programa de alfabetização no presídio da cidade, inspirado na metodologia de Paulo Freire. Depois de um ano de pesquisa sobre a metodologia e a realidade carcerária, o projeto começou a funcionar e foi institucionalizado como um programa de extensão da universidade.

Enquanto pesquisava o universo vocabular dos presos, ia captando algumas transformações que estavam acontecendo no presídio, os presos contavam-lhe que o crack e as mortes no interior da prisão estavam diminuindo, que o ambiente entre os presos estava mais harmonioso. Tudo isso facilitava o novo projeto educacional da pastoral, que além de alfabetizar muito rapidamente um número significativo de detentos, abria espaço para discussões formidáveis entre educadores e presos, sobre os significados profundos de palavras como "Deus", "paz”, "justiça” e "liberdade”. Só

\footnotetext{
${ }^{126}$ Sobre a primeira megarrebelião do PCC, de fevereiro de 2001, ver: SALLA (2006).

${ }^{127}$ Informações em: http://www.cnbb.org.br (Consulta feita em maio de 2010),
} 
algum tempo depois, quando mais conhecedor da realidade carcerária, Pedro pôde associar muitas das discussões que manteve em sala de aula, e muitas das transformações apontadas pelos detentos, à progressiva implantação do PCC também naquela unidade.

A capacidade de trabalho e articulação de Pedro era impressionante. Além do projeto de alfabetização no presídio, ele ajudou a estruturar um cursinho pré-vestibular popular na cidade - que também foi institucionalizado como projeto de extensão universitária - e um projeto de assistência jurídica para pessoas de baixa renda. Ademais, fazia estágio no Ministério Público, articulava retiros e encontros da Pastoral Universitária, e seguia na Pastoral Carcerária. Nos anos de faculdade, sua identidade com o trabalho pastoral só cresceu, e ao se formar, no final de 2000, estava convencido de que deveria entrar no seminário. Já completamente familiarizado com a política interna da Igreja Católica, e estudioso da teologia da libertação, Pedro procurou aquela figura presente na sua infância, que lhe havia aconselhado a terminar o curso universitário antes de pensar na vida religiosa e que era uma grande liderança da Pastoral Carcerária, confirmando-lhe o interesse em ingressar na sua ordem religiosa, os Oblatos de Maria Imaculada (OMI). ${ }^{128}$ Em janeiro de 2001, Pedro inicia sua formação missionária, de modo que quando o PCC explode para todo o mundo, na primeira megarrebelião, ele se encontrava - como Amaro - afastado do ambiente prisional.

\section{6 - (Re)ajustes}

À emergência e consolidação do PCC se sucederam reajustes em diversos elementos dispersos do dispositivo, novos debates e disputas se abriram, novas práticas se desenvolveram. Sem a pretensão de oferecer um diagnóstico preciso e completo do conjunto de efeitos reestruturantes da emergência da facção no interior do dispositivo, agora pretende-se não mais do que assinalar alguns deslocamentos que puderam ser identificados no decorrer da pesquisa.

\footnotetext{
${ }^{128}$ Para mais informações sobre essa ordem religiosa, ver: www.omiworld.org (Consulta em maio de 2010).
} 
Em primeiro lugar, a presença de telefones celulares no interior das prisões, que sempre foi percebida como problemática, foi ganhando centralidade e mobilizando todo um debate sobre suas virtualidades perniciosas e as responsabilidades sobre o seu controle. É sabido que desde meados dos anos 1990, o aparelho de telefone celular vem transformando aceleradamente a sociedade como um todo, e a prisão, obviamente, não ficaria alheia a tais transformações. A popularização e a progressiva diminuição do aparelho telefônico possibilitaram a sua proliferação no ambiente prisional, a ponto de, juntamente com as drogas e as armas, ele constar na lista das mais importantes apreensões que se pode fazer numa prisão. Exatamente a esse artefato tecnológico foi atribuída boa parte da capacidade de articulação do PCC, quando da eclosão da primeira megarrebelião, em 2001 - e novamente em 2006. Sobre sua presença na prisão erigiu-se todo um debate público e uma queda de braço entre operadoras de telefonia celular, a administração penitenciária e o poder judiciário, sobre a necessidade e a responsabilidade da instalação de bloqueadores de sinal nas unidades prisionais. ${ }^{129}$ Portanto, o celular passa a ser visto como um grande "vilão" no interior dos presídios, um forte aliado do chamado "crime organizado". Porém, ainda que essa imagem seja propagada e reforçada pela "opinião pública", o aparelho de telefonia celular é também aliado dos agentes estatais no combate à facção, por meio dos grampos telefônicos. Afinal, por que investir no estabelecimento de contatos discretos entre um agente penitenciário específico e um determinado preso, numa determinada prisão, se atualmente é possível monitorar, desapercebidamente e em tempo real, a conversa de centenas de presos entre si, com seus amigos e familiares, por todo o sistema penitenciário estadual? ${ }^{130}$

Em segundo lugar, a intensificação da ocorrência de rebeliões acarretou uma desestabilização das relações entre a categoria dos agentes penitenciários, a administração penitenciária e outros órgãos governamentais. De acordo com dirigentes do SIFUSPESP - sindicato dos agentes penitenciários de São Paulo - a emergência do

\footnotetext{
${ }^{129}$ Para uma visão geral sobre os principais termos em que se dá o debate, ver: BALAZINA, A. (2006) "Juiz manda bloquear celular em prisões" in Folha de São Paulo, Cotidiano, 18 de maio de 2006; SUCURSAL DE BRASÍLIA (2001) "Governo faz pacote contra rebeliões” in Folha de São Paulo, Cotidiano, 03 de março de 2001; e REPORTAGEM LOCAL (2001) "Governo quer que a USP estude bloqueio de ligações" in Folha de São Paulo, Cotidiano, 22 de fev. de 2001. (Consulta em maio de 2010).

${ }^{130}$ Segundo a jornalista Fátima Souza centenas de horas de conversas telefônicas entre ela e suas fontes no interior das prisões lhe foram apresentadas quando intimada a prestar depoimento num processo de investigação sobre o PCC. Sobre a ampla utilização de grampos telefônicos nas investigações policiais, ver: SOUZA (2007) e JOZINO (2006).
} 
PCC representou uma ainda maior deterioração das condições de trabalho. Nesse novo contexto, o sindicato passa a exigir que as rebeliões sejam consideradas acidentes de trabalho, e que os problemas físicos e psicológicos - que afetam muitos dos funcionários feitos reféns - recebam um tratamento diferenciado por parte do governo, com mínimas garantias de assistência e aposentadoria, e uma regulamentação mais precisa dos procedimentos a serem adotados nessas situações.

Raílton é um agente penitenciário que luta nessa frente de batalha. Ele trabalhava num dos muitos presídios do Oeste Paulista, quando foi feito refém por 32 horas numa rebelião articulada pelo PCC, no começo dos anos 2000. Viu cinco pessoas serem mortas e decapitadas, e desde então está afastado do sistema. Ficou psicologicamente traumatizado, não consegue por os pés numa unidade prisional e toma uma quantidade de remédios psiquiátricos. Nascido na Bahia, foi ainda criança para o Oeste Paulista, onde fez curso técnico de contabilidade e trabalhou em escritório. Em 1992, em busca de estabilidade financeira, prestou concurso público e entrou no sistema prisional. Seu relato é todo centrado na experiência da rebelião: antes ia tudo bem; depois, tudo mal. Vem alternando férias e licenças-prêmio acumuladas, e afastamentos psiquiátricos para manter-se distante do presídio.

Sem trabalhar, suas condições de vida pioraram muito. Estar licenciado ou simplesmente afastado por motivos psiquiátricos fez com que seu salário se reduzisse em mais de $60 \%$, pela perda do direito a todos os bônus e adicionais. Por isso, o sindicato luta para que problemas como o de Raílton sejam considerados seqüelas de acidentes de trabalho, o que obrigaria o Estado a conceder aposentadoria integral, com os bônus incorporados. Pressionado pelas necessidades, Raílton chegou a tentar a volta ao trabalho, mas não pôde suportar o medo. Desistiu. Hoje sua luta é na justiça, pela aposentadoria integral e por uma indenização do Estado, já que, segundo ele, havia falhas no sistema de segurança que foram resolvidas depois da rebelião, o que demonstra que se poderia ter evitado o que lhe aconteceu. Munido de um dossiê sobre seu caso, com fotos suas com uma faca no pescoço no telhado do presídio, fotos dos mortos decapitados; reportagens de jornal, receitas médicas, a planta da prisão e uma lista das alterações que nela foram feitas, ele espera o julgamento, acompanhando dia-adia a evolução de seu processo. Sua trajetória de vida poderia ser apresentada como um típico caso de desestruturação psicológica promovida pela prisão e pelo PCC, porém sua 
batalha atual permite entrever a estruturação de um campo de disputa política e jurídica entre o corpo de funcionários e o governo estadual. O processo de Raílton está abrindo caminho na jurisprudência para mais de trezentos funcionários que se encontram em situação semelhante. E em torno de casos como o de Raílton, o setor de saúde do SIFUSPESP vem estruturando sua pauta de reivindicações.

Essa ordem de embates da categoria ainda se desdobra em outras esferas de governo e para além do problema das condições de vida daqueles que foram afetados por uma rebelião. Com o aumento dos motins e a capilarização de facções prisionais em ambiente aberto em diversos estados da federação (principalmente Rio de Janeiro e São Paulo), a segurança pessoal do agente penitenciário na prisão, na rua, ou mesmo em casa, tornou-se um problema cada vez mais agudo, frente ao qual entidades representativas de diversos estados vêm formulando outras propostas e reivindicações, sendo a principal delas a estruturação da Polícia Penal. Esse embate vem se dando na esfera do Congresso Nacional, em torno da aprovação da PEC-308, que procura regulamentar os serviços penitenciários em todo o Brasil, conferindo uma estrutura mais uniforme e poder de polícia aos trabalhadores dos sistemas penitenciários estaduais. ${ }^{131}$ Representantes da categoria defendem que assim os funcionários estariam menos vulneráveis à ação das facções.

Outro efeito imediato da eclosão do PCC foi a criação e institucionalização do Regime Disciplinar Diferenciado (RDD), primeiro nos presídios paulistas (em 2001), e em seguida, o estabelecimento da possibilidade de sua replicação em todo o território nacional (pela reforma da LEP em 2003). Teixeira (2006) pesquisou a fundo os significados desse deslocamento, escrevendo sobre suas circunstâncias:

"Assim, logo após a megarrebelião, o Secretário Nagashi, os coordenadores e um assessor especial que ocupava o cargo de Ouvidor da SAP, Pedro Armando Egydio de Carvalho, permaneceriam reunidos durante dias para a elaboração da resolução que instituiria o regime disciplinar diferenciado - RDD, como principal medida anunciada para o combate das organizações criminosas nos presídios paulistas. Segundo Pedro Egydio, naquele momento eram intensas as pressões que se exerciam

\footnotetext{
${ }^{131}$ Para maiores informações sobre o projeto de emenda constitucional, seus motivos e circunstâncias, ver: FEBRASPEN (2009).
} 
no sentido de "endurecer" ao máximo o tratamento aos presos envolvidos em facções e com problemas de indisciplina." (TEIXEIRA, 2006, p.147 grifo meu)

Quase simultaneamente à institucionalização do RDD, no esforço de enfrentar a existência da facção prisional, foi criado também o Grupo de Intervenção Rápida (GIR), idealizado e instituído pelo diretor do CDP de Sorocaba, Márcio Coutinho, em 2002. Segundo esse diretor, os motivos que levaram à sua criação foram: 1 - a mudança de perfil do preso paulista, segundo ele, mais jovem e problemático; 2 - os entraves na mobilização imediata da tropa de choque da Polícia Militar em situações de crise e risco. "A solução encontrada foi criar um grupo de agentes de segurança penitenciária, especialmente treinados e equipados para dar a pronta resposta em situações de risco ou início de rebeliões"; afirma o diretor em entrevista divulgada pela SAP. ${ }^{132}$ O projeto piloto, no CDP de Sorocaba, foi viabilizado através de doações de empresas produtoras de proteção balística (escudos, capacetes, caneleiras, coletes, etc.) e munições não letais (bombas de efeito moral, gás de pimenta, bala de borracha, etc.); a SAP apoiou o projeto intermediando cursos de "Entradas explosivas e táticas", "Combate em ambiente fechado", e "Resgate de reféns de alto risco" na Tactical Explosive Entry School Brazil (TEES-BR); "Gerenciamento de crises e negociação" na Polícia Militar; e "Explosivos não convencionais" na Indústria de Material Bélico do Brasil (IMBEL); entre outros. Em 2003, o grupo foi regulamentado por uma resolução da SAP, e começou a operar "ações preventivas" "133 em diversas outras unidades do sistema penitenciário paulista. Com o tempo, novos pelotões foram sendo formados, até o número de oito unidades que operam atualmente.

As "ações preventivas" são as costumeiras blitzes em pavilhões e unidades prisionais inteiras, para encontrar armas, drogas e telefones celulares. Nas décadas de 1980 e 1990, esse tipo de prática sucedia rebeliões, e era realizada pelos quadros da Polícia Militar. A partir da criação do GIR, a SAP já não precisa requisitar a colaboração da SSP e da polícia, podendo realizar autônoma e preventivamente suas revistas massivas. O caráter dos cursos de formação, os artefatos empregados e a rápida expansão do GIR indicam a tendência dos novos atributos necessários e valorizados no agente

\footnotetext{
${ }^{132}$ Informação disponível em: http://www.sap.sp.gov.br/common/entrevistas/entr002.html (Consulta em maio de 2010).

${ }^{133}$ Palavras do diretor Marcio Coutinho na já citada entrevista.
} 
penitenciário - e da obsolescência daqueles conhecimentos práticos de funcionários como Amaro. Como já foi apontado, se a Polícia Penal ainda é uma virtualidade, em São Paulo, sua "tropa de choque" já é uma realidade estabelecida.

Reajustes são perceptíveis também na própria materialidade do parque penitenciário estadual e nacional. Em 2002, a Casa de Detenção de São Paulo foi finalmente desativada e implodida; dois anos mais tarde, a Penitenciária do Estado foi desativada, reformada e convertida na Penitenciária Feminina de Santana. Em 2006, foram inauguradas as primeiras prisões federais de segurança máxima - em Catanduvas, no Paraná; e Campo Grande, no Mato Grosso do $\mathrm{Sul}^{134}$ - para receber as principais lideranças das principais facções prisionais do país. ${ }^{135}$

Um último reajuste a ser destacado diz respeito ao desenvolvimento de uma estratégia de intensificação das transferências de presos com vistas a minar a implantação da facção nos interior dos presídios. Esse deslocamento se evidencia na trajetória de Paulo, que atualmente cumpre pena em regime semi-aberto. Paulo nasceu em 1974, no Paraná, e migrou para o interior de São Paulo com a mãe quando tinha menos de um ano. Aos 22, em 1996, foi preso por envolver-se num latrocínio. Ficou detido numa carceragem de delegacia por um ano e três meses, depois de uma tentativa de fuga, foi transferido para a Casa de Detenção de São Vicente, onde passou aproximadamente seis anos. Por volta de 2003, Paulo já era um dos presos mais antigos e respeitados da casa, e por isso acabou sendo associado à facção e transferido para a Penitenciária de Mirandópolis. A partir daí os seis anos seguintes de cumprimento de pena se passaram num perpétuo remanejamento, sem ficar um ano sequer numa mesma unidade. Apesar dos muitos convites que recebera, Paulo nunca entrou no PCC, conhecia e tinha bom relacionamento com os integrantes mais eminentes, assumia posições importantes em diferentes setores do presídio ao lado deles, mas nunca quis entrar formalmente na organização. De qualquer maneira, pelo alto respeito que tinha, pela proximidade com os integrantes da facção, e pelas posições que assumia, tornou-se freqüente objeto de

\footnotetext{
${ }^{134}$ Segundo o Ministério da Justiça, outras duas unidades federais estão concluídas, uma em MossoróRN, outra em Porto Velho-RO, e uma em Brasília-DF está em planejamento. Informações disponíveis em: http://portal.mj.gov.br/data/Pages/MJ887A0EF2ITEMID5AC72BD609F649AEBDB09A5A1D5A28B9P TBRIE.htm (Consulta feita em maio de 2010)

${ }^{135}$ É importante ressaltar que a eclosão do PCC entra em ressonância com as dificuldades encontradas para definir um lugar de cumprimento de pena para Fernandinho Beira-Mar, considerado um dos líderes máximos do Comando Vermelho.
} 
remanejamentos, sendo submetido a uma saga pelos presídios paulistas. Em menos de seis anos, passou pelas penitenciárias um e dois de Presidente Venceslau, um e dois de Lavínia, um e dois de São Vicente, e uma das penitenciárias de Iaras, Campinas, Tremembé, Iperá, Guareí até chegar ao CPP de Franco da Rocha, quando finalmente conseguiu o benefício de regime semi-aberto. Segundo Paulo, o maior inconveniente desse período de transferências contínuas eram as longas viagens num camburão sem ventilação, com as mãos e os pés algemados, sem alimentação e com pouca água. A inserção e a adaptação na unidade prisional era rápida e tranqüila, o PCC controlava todas elas, de modo que os procedimentos e ambiente eram praticamente sempre os mesmos. E depois de uma década no interior do sistema prisional paulista era impossível que chegasse a uma unidade em que não houvesse nenhum conhecido para bem acolhê-lo, oferecendo-lhe uma bermuda, um sabonete, uma toalha e um telefone para avisar a família do novo endereço.

\section{7 - (Re)ações}

A cada reajuste num campo do dispositivo, reações se dão em outros campos, num contínuo ir e vir de causas e efeitos. Às políticas de endurecimento do tratamento penitenciário - via RDD e GIR - e de intensificação das transferências, o PCC reagiu, ampliando seu repertório de práticas. Após a implantação do RDD, entre 13 e 18 de fevereiro de 2002, três granadas explodiram diante do edifício sede da SAP, no centro de São Paulo. ${ }^{136}$ Em 19 de fevereiro, dispararam contra a porta principal do Fórum de São Vicente, matando um advogado - este foi a primeira vítima fatal de um atentado atribuído ao PCC na rua. Em outubro de 2002, quando se acabavam os primeiros seis meses de RDD previstos para aqueles considerados principais líderes da facção, a SAP estendeu o regime por mais seis meses. Logo, o PCC voltou a atacar com bombas e disparos, diversos edifícios do aparato judiciário e policial. A partir de então se consolida essa possibilidade de desdobrar um conflito interno ao sistema penitenciário no ambiente aberto. É nesse novo horizonte de possibilidades de expressão de uma das

${ }^{136}$ As informações sobre os atentados do PCC em ambiente aberto estão em: SOUZA (2007). 
disputas inerentes ao dispositivo carcerário que se inserem os trágicos eventos de maio de 2006, quando o PCC, reagindo a transferência de 765 detentos para um presídio de Presidente Venceslau, promoveu a segunda megarrebelião e mais de 200 atentados em ambiente aberto. ${ }^{137}$

Porém, é importante ressaltar que as reações a alguns dos reajustes não se restringem às dimensões tectônicas do repertório de práticas da facção prisional, sendo também observáveis nas esferas gravitacionais do dispositivo. Por exemplo, em torno do RDD se mobilizou todo um conjunto de agentes e entidades civis contrários à medida. Teixeira (2006) menciona abaixo-assinados promovidos pela Pastoral Carcerária, bem como a incisiva atuação do Instituto Brasileiro de Ciências Criminais (IBCCRIM), que questionou publicamente a legalidade da resolução, por meio de artigos, debates e editoriais em suas publicações.

Ademais, nesse contexto de ampla reconfiguração do dispositivo carcerário, outras tantas ações e reações concorrem em suas esferas gravitacionais, inclusive desdobrando - sob uma nova correlação de forças - alguns embates históricos em torno das perpétuas questões da violação dos direitos dos presos, das péssimas condições de cumprimento de pena, das nulas possibilidades de ressocialização, etc. A efetiva estruturação de dois aparatos judiciários de promoção dos direitos dos presos - que estavam previstos em lei desde a década de 1980 - exatamente no período de maior esforço de endurecimento penal, mostram como os reajustes e reações no interior do dispositivo são múltiplos, complexos e, às vezes, contraditórios. Só pela perspectiva de um campo complexo e multifacetado que se articula ao redor de uma prisão sempre extremamente precária, que se pode apreender a quase simultaneidade da estruturação de aparatos de endurecimento punitivo como o GIR e o RDD, ao lado de aparatos de realização de direitos, como é o caso da Defensoria Pública do Estado de São Paulo e do Conselho da Comunidade da Comarca de São Paulo.

Os serviços de Defensoria Pública estavam previstos desde a Constituição Federal de 1988, mas no estado de São Paulo, até 2006, eram viabilizados através de um arranjo institucional quase informal. A Procuradoria do Estado "emprestava" alguns de seus quadros para os serviços de defesa pública em todas as áreas do direito. No campo da

${ }^{137}$ Sobre os eventos de maio de 2006, ver: ADORNO e SALLA (2007) e GRIMBERG (2009). 
execução penal, o trabalho dos pouquíssimos procuradores-defensores públicos era complementado, de um lado, por advogados da FUNAP - fundação governamental ligada à administração penitenciária -; e de outro, por advogados autônomos, intermediados pela Ordem dos Advogados do Brasil (OAB) - entidade civil de representação dos advogados - que assumiam casos e recebiam remuneração por produtividade (esses são conhecidos como "dativos"). A quase formalidade da defesa pública era extensiva a esses dois coletivos. No âmbito informal, a assistência jurídica gratuita era complementada ainda pela atuação de entidades como a Pastoral Carcerária, que mobilizavam o trabalho voluntário de advogados como Pedro.

Desde 2002, na base desse aparato improvisado de defesa, foi se estruturando um novo sistema de atendimento ao público. No Fórum Criminal da Barra Funda, em São Paulo, a Procuradoria e a FUNAP criaram um setor composto de três salas, nas quais procuradores-defensores, advogados da FUNAP, e uma equipe de estagiários, faziam o atendimento direto de egressos, sentenciados em regime aberto e familiares de presos. Centenas de senhas passaram a ser diariamente distribuídas, para que os interessados tivessem acesso ao andamento de seus processos, ou de seus familiares, e conforme as circunstâncias, pudessem requerer progressão de regime, e outros benefícios legais. A centralização desses serviços de atendimento num espaço de referência da cidade de São Paulo representou um significativo deslocamento nesse âmbito de práticas estatais, que anteriormente espalhavam-se num indecifrável labirinto kafkiano de comarcas, varas e repartições.

Também em 2002, um conjunto de diversas organizações civis - algumas remanescentes, outras herdeiras das lutas e movimentos da década de 1980, e outras novas que foram surgindo com o passar do tempo - lançou o Movimento pela Defensoria Pública em São Paulo ${ }^{138}$, já apresentando um projeto de lei que

\footnotetext{
${ }^{138}$ Cuja direção contava com representantes das seguintes instituições: Conselho Estadual de Defesa dos Direitos da Pessoa Humana (CONDEPE); Comissão Teotônio Vilela de Direitos Humanos (CTV); Sindicato dos Procuradores do Estado, das Autarquias, das Fundações e das Universidades Públicas do Estado de São Paulo (SINDIPROESP); Centro Acadêmico XI de Agosto da Faculdade de Direito da USP; Comitê Latino-Americano e do Caribe para a Defesa dos Direitos da Mulher (CLADEM-Brasil); Fala Preta Organização das Mulheres Negras e Centro de Direitos Humanos do Sapopemba (CDHS).
} 
regulamentasse a sua criação. Entre idas e vindas, manifestações públicas e pressão na Assembléia Legislativa, a Defensoria foi finalmente instituída, em janeiro de $2006 .{ }^{139}$

O complexo arranjo institucional dos serviços de defesa pública na área penitenciária rede de defensores, advogados da FUNAP e "dativos" - não se modificou substancialmente com a criação da Defensoria Pública, mas ganhou um outro ponto de ancoramento na estrutura estatal, com maior autonomia e maiores possibilidades de expansão. Segundo um defensor entrevistado, a Defensoria iniciou suas atividades contando com um quadro de 400 defensores, o que representava um grande salto frente os cerca de 80 procuradores-defensores que atuavam na área anteriormente, e em 2009, novo concurso foi aberto para a contratação de mais 100 profissionais. Além disso, o mesmo defensor conta que, assim que a Defensoria iniciou suas atividades, em sua cúpula, foram estruturados diversos núcleos especializados em diferentes áreas do direito, com o fim de qualificar a intervenção da instituição e promover ações judiciárias consideradas estratégicas. Um deles é o núcleo especializado em "Situação Carcerária" "140, que visa principalmente a formulação de intervenções judiciárias de caráter difuso ou coletivo, como o direito ao voto dos presos preventivos. É evidente que tais deslocamentos alteram significativamente o campo dos embates jurídicos no interior do dispositivo carcerário paulista.

Parece-me importante situar a estruturação dos serviços de defensoria pública em São Paulo nesse mais amplo processo de reconfiguração do dispositivo carcerário, que se dá no começo dos anos 2000, também porque ela vinha a responder urgências que ficavam cada vez mais patentes para os operadores do sistema prisional e para a sociedade em geral. No mesmo ritmo em que aumentava a população carcerária, aquele muito precário arranjo institucional quase informal se debilitava. Sua capacidade de fluxo processual se reduzia, de tal modo que pessoas presas em condições de aceder a benefícios de progressão de regime, ou à própria liberdade, ficavam retidas no sistema prisional, e esse era um dos combustíveis mais inflamáveis que ardiam em diversas das rebeliões articuladas e deflagradas pelo PCC. Nesse sentido, uma conquista histórica de

\footnotetext{
${ }^{139}$ Para mais informações sobre o processo de estruturação da Defensoria Pública de São Paulo, ver: MELO (2007), MUNIZ (2009) e SOARES (2009).

${ }^{140}$ Ver: http://www.defensoria.sp.gov.br/dpesp/Default.aspx?idPagina=3016 (Consulta feita em maio de 2010)
} 
um movimento social também histórico, é ademais uma reação urgente a uma crise deflagrada.

No mesmo contexto de criação da Defensoria, dava-se um segundo processo de (re)estruturação de práticas estatais bastante pautado pela pressão e intervenção, de um lado, de históricas entidades civis de promoção de direitos, e de outro, pelas forças da urgência decorrentes de um sistema prisional precarizado e em crise. Trata-se da estruturação dos Conselhos da Comunidade, previstos como órgãos auxiliares de execução penal desde a LEP de 1984, mas que só no final dos anos 1990 e começo dos 2000 foram se concretizando. Sob essa rubrica todo um mundo social de agentes e práticas, estatais e não-estatais, vai se estruturando. Entre 2007 e 2008, o Departamento Penitenciário Nacional (DEPEN) organizou um diagnóstico dos Conselhos da Comunidade em todo o país, identificando a existência de 639 conselhos instalados em 23 estados, no ano de 2006. Só o estado de São Paulo concentrava 89 desses conselhos (DEPEN, 2008).

A designação de um "mundo social" em estruturação não é arbitrária, faz referência a imensa variabilidade da composição e da atuação que existe entre os conselhos, ou mesmo no interior de um deles. Segundo o DEPEN, existem aqueles conselhos instalados mas que não funcionam, aqueles que funcionam mas não cumprem integralmente suas atribuições legais ${ }^{141}$, e aqueles que as cumprem. Existem ainda conselhos compostos integralmente por funcionários do aparato penitenciário e de justiça. ${ }^{142}$ Quando há participação de representantes da sociedade civil, esta também é muito variada. Segundo alguns conselheiros entrevistados, existem desde conselhos de uma só pessoa - como em São Vicente, cujo único conselheiro é um agente da Pastoral Carcerária - até conselhos, como o de São Paulo, de composição mais ampla e extremamente variada, reunindo representantes da Pastoral Carcerária, Defensoria Pública, Serviço Social da Indústria (SESI), Federação das Indústrias do Estado de São Paulo (FIESP), Federação do Comércio de Bens, Serviços e Turismo do Estado de São Paulo (FECOMERCIO), universidade, organizações não-governamentais, alguns advogados criminalistas, ex-funcionários do poder judiciário e até um egresso. $\mathrm{O}$

\footnotetext{
${ }^{141}$ Principalmente no que diz respeito ao envio de relatórios periódicos ao juiz da Vara de Execuções Penais da comarca.

${ }^{142}$ Esse é o caso do Conselho da Comunidade do Espírito Santo, segundo o DEPEN (2008), e do Conselho da Comunidade da Comarca de Guareí-SP, segundo um conselheiro de São Paulo, entrevistado em 2009.
} 
Conselho da Comunidade da Comarca de São Paulo - que tive a oportunidade de conhecer mais de perto - foi constituído em 2005 e tem um perfil marcadamente fiscalizador das instituições prisionais, valorizando as visitas às unidades, a elaboração e encaminhamento de relatórios ao juiz corregedor e o acompanhamento de casos específicos de presos mantidos sob certas condições irregulares. Ainda, os conselheiros promovem, na medida das possibilidades e não sem dificuldades, cursos profissionalizantes para grupos de presos da região sob sua jurisdição. Eis mais uma peça que se agrega ao dispositivo, que impõe maior complexidade ao seu processo de reconfiguração, e que acaba por abarcar e promover a gravitação de um conjunto maior e mais diversificado de agentes, práticas e discursos em torno do problema penitenciário.

Mas, no decorrer da pesquisa, foi possível ainda identificar outras ações e reações que remetem cada vez menos aos campos gravitacionais do encarceramento que vão se constituindo desde a década de 1980. Jozino (2006, 2008) relata que, em 2001, em oposição ao estabelecimento do RDD, um grupo de mulheres de presos (alguns ligados ao PCC) constituiu a Comissão de Parentes e Amigos de Detentos do Estado de São Paulo (CEPAD), que chegou a realizar reuniões na Câmara de Vereadores da capital, a contar com o apoio de advogados, assessores parlamentares, organizações nãogovernamentais de defesa dos direitos humanos, inclusive da Pastoral Carcerária. Porém, sem conseguir impedir a instalação do RDD, a CEPAD foi dissolvida ainda no final de 2001. Logo, esse emergente campo político de familiares e amigos de presos, não obstante sua conformação em um contexto democrático, vai acabar sendo mais comumente associado à criminalidade, e em especial à facção.

Em 18 de abril de 2005, ocorreu na frente da SAP a maior manifestação pública de familiares e amigos de presos que se tem notícia: mais de oito mil pessoas, que vieram de todo o estado em duzentos ônibus, reuniram-se para protestar contra as alterações promovidas pela SAP no regulamento da visita aos presídios, que acabavam com a possibilidade de "dobradinha" - a realização de visitas aos sábados e domingos. Segundo Jozino (2006), esse movimento já não contava com o apoio de entidades como a Pastoral Carcerária e nem de outras organizações defensoras de direitos humanos. $\mathrm{O}$ secretário da administração penitenciária recebeu uma comissão das familiares e ouviu suas reivindicações. Porém, as componentes da comissão recebida pelo dirigente da 
SAP tiveram seus telefones grampeados e foram continuamente investigadas pela polícia, de modo que, em pouco tempo, muitas delas se encontravam presas, sob acusações diversas. Outra manifestação análoga se deu em 2007, dessa vez em Brasília, e organizada por uma associação de familiares de presos do Oeste Paulista. Jozino (2008) afirma que, nessa ocasião, por volta de duas mil pessoas se reuniram diante do Congresso Nacional, e uma pauta de reivindicações foi entregue ao presidente da CPI do Sistema Carcerário, que se desenrolava na ocasião. Da mesma forma, investigações foram iniciadas para apurar o envolvimento do PCC na organização da manifestação.

Desses episódios pontuais infere-se a existência de um processo de estruturação de um campo político de familiares e amigos de presos do estado de São Paulo, que se dá nos limiares da criminalização. A cada eclosão pública desse tipo de movimento, o aparato estatal logo associa a participação do "crime organizado", acusando a facção prisional de financiar e planejar as atividades.

Sem a pretensão de refutar ou comprovar essas suspeitas das agências estatais, o que interessa demarcar aqui é que no campo gravitacional do dispositivo carcerário circula uma miríade de agentes e instituições, com diferenciados processos de estruturação, com diversos campos de atuação, e com diferentes padrões de relacionamento com as agências estatais, e que não obstante tanta diversidade, todos eles, direta ou indiretamente, são solapados e obrigados a reagir a um dispositivo que se reestrutura em todos os níveis, desde suas mais profundas camadas tectônicas.

\section{8 - Reverberações}

O processo de (re)estruturação do dispositivo carcerário paulista nas últimas décadas, como se procurou demonstrar, é, efetivamente, marcado pela emergência do PCC, representando um verdadeiro abalo sísmico em todo o campo. Porém não se deve reduzir a (re)estruturação do dispositivo aos deslocamentos mais diretamente relacionados ao problema da facção. No decorrer da pesquisa foram identificados outros elementos do campo que se estrutura ao redor da prisão que, embora também reflitam 
sinais do grande abalo, passam por outras cadeias de variáveis e são conformados por outros processos históricos e sociais. Uma vez que se considera o dispositivo como uma ampla rede articulada de agentes, práticas e discursos, que se desdobra para além do domínio mais direto de um sistema prisional estadual, torna-se possível pontuar nessa cartografia uma série de outras peças, de elementos dispersos em outros pontos e escalas territoriais que, com mais ou menos força, também fazem da prisão uma referência circulante para muito além de seus limites físicos e institucionais.

Refere-se aqui a uma dimensão do dispositivo que tampouco se confunde com o campo gravitacional de agentes, práticas e discursos que desde fora da prisão disputam as condições de cumprimento de pena, que defendem ou atacam os direitos humanos, e que armam tantas outras disputas em torno do encarceramento. Trata-se de zonas de reverberação nas quais a prisão também emerge como questão, também é problematizada, e que, portanto, também compõem o dispositivo, conectando-se, de diversas maneiras, a suas camadas tectônicas e gravitacionais, sem serem redutíveis a elas.

A progressiva centralidade da prisão em produções recentes do jornalismo investigativo, a especialização de jornalistas no tema prisional e o crescente volume dessa produção no Brasil poderiam ser vistos como sinais da conformação de uma dessas importantes zonas de reverberação. Por meio dessa produção são formulados discursos, denúncias, críticas e apologias do sistema carcerário, por meio deles "verdades" sobre a prisão são constituídas, seus segredos são desvendados, sua dura realidade transborda, seus problemas afetam. Por meio desses verdadeiros vetores de expansão, o dispositivo carcerário alcança domínios sociais imprevistos.

A enumeração de alguns agentes estratégicos desse campo pode ajudar a melhor demarcá-lo nessa cartografia. Começaria, então, com alguns exemplos de jornalistas especializados que "desvendaram" os meandros prisionais para o grande público. Em primeiro lugar, o pioneiro jornalista Percival de Souza, que desde "A Prisão: histórias dos homens que vivem no maior presídio do mundo" (1977), "O Prisioneiro da Grade de Ferro" (1983), até o "Sindicato do Crime: PCC e outros grupos" (2006), publicou mais de uma dezena de livros que abordam a realidade prisional e suas adjacências. Em segundo lugar, o jornalista carioca Carlos Amorim, que em "Comando Vermelho: a história secreta do crime organizado" (1993) foi um dos primeiros a formular 
publicamente a hipótese de colaboração entre presos políticos e comuns, no presídio da Ilha Grande, para explicar a origem da principal facção prisional do Rio de Janeiro argumento que se desdobrou em seu segundo trabalho " $C V$-PCC: a irmandade do crime" (2003). Em terceiro lugar, Caco Barcellos, jornalista que se consagrou com o livro "Rota 66: a polícia que mata" (1997), e chegou à prisão contando a vida de um traficante carioca em "Abusado: o dono do morro Dona Marta" (2003). Em quarto lugar, Antonio Carlos Prado, que depois de sete anos desenvolvendo trabalhos voluntários num presídio feminino, publicou “Cela Forte Mulher" (2003). A já citada Fátima Souza, autora de "PCC: a facção" (2007), que em 1997 foi a jornalista responsável pelo "furo" de noticiar a existência do PCC, e o também já citado Josmar Jozino, que em "Cobras e Lagartos: a vida íntima e perversa nas prisões brasileiras" (2006) e em "Casadas com o Crime" (2008) explora a realidade prisional paulista contemporânea a partir de contatos com as mulheres dos presos mais influentes de São Paulo.

Porém, não são apenas os jornalistas investigativos que se arriscam a tornarem públicos os segredos das instituições penitenciárias. O promotor de justiça do estado de São Paulo, e membro do Grupo de Atuação Especial de Repressão ao Crime Organizado (GAECO), Márcio Christino, aventurou-se na literatura com "Por Dentro do Crime: corrupção, tráfico, PCC" (2003), uma narrativa policial, na qual muito de sua experiência profissional parece ser traduzida em termos ficcionais. Os advogados criminalistas Anselmo Neves Maia e Mário Sérgio Mungioli - conhecidos por defenderem algumas lideranças do $\mathrm{PCC}^{143}$ - também se aventuraram a plasmar suas experiências profissionais em ensaios reunidos no livro "Prisioneiras da Opressão: aspectos da vida de familiares e amigos de internos no sistema prisional" (2002), editado por AFAISCA - sigla de Associação de Familiares e Amigos de Internos do Sistema Carcerário.

A fotógrafa Maureen Bisilliat produziu e organizou o livro "Aqui Dentro: páginas de uma memória - Carandiru" (2003), no qual suas fotos do interior da prisão são mescladas a relatos e entrevistas de presos que vivenciavam o ocaso do maior presídio da América Latina, a Casa de Detenção de São Paulo. Obviamente, não poderia excluir

\footnotetext{
${ }^{143}$ Em diferentes ocasiões ambos foram presos, acusados de prestarem serviços ilegais ao "crime organizado".
} 
desse sumário, o best-seller do médico Dráuzio Varella, “Estação Carandiru” (1999), que por sua ampla circulação certamente foi para muitos um primeiro contato mais intimista com a realidade do sistema prisional paulista.

Se se afasta ainda mais do campo de produção jornalística para adentrar de vez no mundo da literatura, é preciso considerar toda uma outra linhagem de produções que se multiplicaram nos últimos anos: a dos relatos auto-biográficos de presos e egressos, que narram em primeira pessoa os subterrâneos do sistema prisional. Eis alguns exemplos importantes: 1 - o livro "Beco Sem Saída: eu vivi no Carandiru” (1999) de Neninho de Obaluaê, histórico militante do movimento negro paulista; 2 - "Diário de um Detento" (2001) de Jocenir, que ganhou notoriedade por compor com Mano Brown música homônima; 3 - os livros de Luis Alberto Mendes, "Memórias de um Sobrevivente" (2001) - que conta sua experiência em instituições penais para menores e nos presídios na década de 1970 - e “Às cegas" (2005) - focado em sua trajetória no decorrer da década de 1980 e início da de 1990; 4 - “Quatrocentos contra um: uma história do Comando Vermelho" (2001) de William da Silva Lima, membro fundador da principal facção prisional carioca; 5 - "Sobrevivente André du Rap (do Massacre do Carandiru)" (2002), uma parceria de André du Rap e Bruno Zeni; e 6 - "Letras de Liberdade" (VÁRIOS AUTORES, 2000), coletânea de contos premiados num concurso de literatura desenvolvido no interior do sistema prisional paulista.

A mera enunciação desses exemplos já é suficiente para fazer uma idéia da dimensão discursiva do dispositivo carcerário, de uma verdadeira zona de reverberação onde diferentes aspectos e momentos do dispositivo são colocados em evidência, trazidos à tona, problematizados. Essa zona de reverberação se expande ainda mais se se considerar que muitas dessas formulações literárias sobre a prisão foram amplamente difundidas quando traduzidas em outros formatos, de maior alcance, como o cinema. $\mathrm{O}$ momento conhecido como de retomada do cinema brasileiro (anos 2000) é pontuado por mega-produções que colocam a prisão em primeiro plano. "Carandiru” (2002), de Hector Babenco, foi um grande sucesso de bilheteria inspirado no livro de Varella. “Quase Dois Irmãos" (2004), de Lucia Murat, fundamenta-se em algumas formulações de Amorim. "Salve Geral" (2009), de Sergio Rezende, é uma narrativa ficcional baseada em fatos reais que traz algumas informações sistematizadas por Fátima Souza e Josmar Jozino. Para agosto de 2010 está previsto o lançamento nacional de "400 contra 
1: a história do Comando Vermelho", de Caco Souza, que traduz para o cinema os relatos autobiográficos de Lima, o "Professor" do Comando Vermelho. Também poderia citar o documentário quase etnográfico intitulado "O Prisioneiro da Grade de Ferro" (2003), de Paulo Sacramento, que leva o nome do livro de Percival de Souza, mas que é uma montagem de materiais produzidos pelos próprios detentos do Carandiru durante uma oficina de cinema; e "Entre a Luz e a Sombra" (2009), de Luciana Burlamaqui, que, entre outras histórias, acompanha a trajetória de um muito conhecido grupo de rap, criado no interior do sistema penitenciário paulista. ${ }^{144}$

Deixando o campo das mega-produções e explorando o universo dos curtas-metragens, a produção cinematográfica sobre a prisão torna-se ainda mais prolixa e variada. Alguns exemplos serão suficientes para demonstrá-lo: 1 - "Dia de Visita" (1988), de Reinaldo Pinheiro e Umberto Martins, é um documentário que explora a realidade das mulheres que visitam os seus maridos presos; 2 - a mesma temática foi trabalhada por Claudio Nunes e Juliana Cristina da Penha, em "Aqui Fora" (2004); 3 - "Agna" (2007), de Márcia Machado, conta a trajetória de uma presidiária de Brasília; 4 - "Clarissas" (2005), de Tiago Gomes, documenta o cotidiano de um presídio feminino do Rio de Janeiro; 5 - "Cuidar de Quem Cuida" (2006), de Gijs Andriessen e Rose Dalney, apresenta e discute questões relativas ao cotidiano dos agentes penitenciários cariocas; 6 - "Dia do Caçador" (2005), de Carlos Kleber, é uma animação que narra uma tentativa de fuga do presídio da Ilha Grande; 7 - "Freqüência Hanói” (2006), de Daniel Lisboa e Diego Lisboa, realizado a partir da utilização clandestina de celulares num presídio baiano; 8 - "Contatos" (2000), de Rene Sampaio, é uma narrativa surrealista, na qual detentos de um presídio de segurança máxima são abduzidos por extraterrestres. ${ }^{145}$ Por esse conjunto de exemplos é possível afirmar que o cinema nacional também foi arrebatado pelo encarceramento, ampliando em muito o escopo do campo de produção de discursos e envolvimento de agentes no interior do dispositivo carcerário.

Também se deve considerar o mundo dos saberes especializados como uma importante zona de reverberação que estrutura o dispositivo carcerário. Existe uma vultosa produção discursiva sobre a prisão nos campos jurídico, médico e criminológico, que

\footnotetext{
${ }^{144}$ Seguramente o rap é também uma peça prática e discursiva que (re)estrutura o dispositivo carcerário. Infelizmente não foi possível contemplá-la nessa cartografia.

${ }_{145}$ Todos os curtas citados estão catalogados, e alguns deles disponíveis, em: www.portacurtas.com.br (Consulta em maio de 2010).
} 
por sua vastidão aqui não poderá ser explorada, apenas apontada. Já para o campo das ciências sociais, é possível recorrer ao trabalho de Salla (2006b), quando discute a evolução das pesquisas acadêmicas sobre o tema prisional nessa área do conhecimento. Segundo esse autor, no Brasil, a prisão tardou a despertar o interesse dos cientistas sociais, ficando, desde o século XIX até a segunda metade do século XX, mais restrita ao leque de interesses dos juristas e criminólogos. Na década de 1970 surgem os primeiros trabalhos que abordam as prisões brasileiras através de questões e métodos mais próximos da sociologia e da antropologia. Os trabalhos de Thompson (2002), publicado originalmente em 1976, e de Ramalho (2002), em 1979, podem ser considerados marcos inaugurais desse campo de reflexão. No decorrer das décadas de 1980 e 1990, no contexto de redemocratização do país e de persistência de problemas históricos nas prisões - relacionados com a superlotação, com as graves violações de direitos, com a violência reinante - o interesse sobre o tema prisional nas ciências sociais se consolida. Nesse período cria-se um campo de debate sobre a prisão nas ciências sociais brasileiras que, embora relativamente reduzido, envolve um número significativo de importantes pesquisadores e instituições. Já a partir dos anos 2000, a produção acadêmica desse campo recebe um forte incremento, processo que assim é explicado por Salla:

"A regularidade na produção ao longo dos anos 1990 dos estudos produzidos na universidade sobre questões prisionais e depois seu considerável aumento nos anos 2000 estiveram associados a dois fatores. Em primeiro lugar, a instável situação da área de segurança pública no país com o aumento da criminalidade, as deficiências do aparato de repressão, as taxas crescentes de encarceramento mantiveram em destaque a agenda dos debates sobre as rebeliões, a superlotação, a violência, a tortura, o papel da prisão na sociedade, sobre a sua capacidade de controle sobre o crime e sobre as perspectivas de reintegração dos presos à sociedade. Em segundo lugar, a produção de alguns professores entre os anos 1980 e 1990, e sua atuação em torno do tema em fóruns acadêmicos, revelava a disponibilidade de quadros especializados e estimulava o aparecimento de novos estudantes interessados na área que passavam a contar com orientadores para os seus trabalhos." (SALLA, 2006b, p.6) 
Salla ainda sugere que essa explosão dos saberes que se voltam para a prisão é acompanhada de um processo de diversificação temática, com o pensamento social se detendo em diversos aspectos do encarceramento, como a educação penitenciária, os serviços sociais voltados para a prisão, a dinâmica das relações entre os presos, as funções do agente penitenciário, a saúde física e mental nas instituições prisionais, o trabalho no cárcere, o encarceramento de mulheres, a história das prisões, etc. Essa diversificação dos temas prisionais acaba por conferir uma dimensão discursiva a elementos do dispositivo que anteriormente se restringiam a uma existência prática (ou muda). E o movimento inverso também parece ser realizado, quando problemas formulados no campo acadêmico são transpostos e inscritos no dispositivo via diversos agentes, que mobilizam esses saberes para municiar intervenções práticas.

Um interessante indicador desse trânsito é a emergência do Grupo de Diálogo Universidade-Cárcere-Comunidade (GDUCC), projeto de extensão universitária do Departamento de Direito Penal, Medicina Forense e Criminologia da USP. Suas atividades começam em 2006, sob orientação dos professores de criminologia Alvino Augusto de Sá e Sérgio Salomão Schecaira. Nesse projeto, estudantes de diversas disciplinas desenvolvem estudos sobre a realidade prisional e o processo de reintegração social, e realizam um programa de atividades no interior da Penitenciária José Parada Neto, em Guarulhos. Tive a feliz oportunidade de participar do início das atividades da segunda edição desse projeto, em 2007. As reuniões com grupos de presos no interior da penitenciária objetivam aproximar os estudantes da realidade carcerária e os presos do mundo exterior, através de dinâmicas de grupo variadas. Sem deter-me numa discussão sobre o conteúdo do projeto, o que interessa aqui apontar é o crescente interesse que essa experiência vem despertando. ${ }^{146}$ Desde 2008, os coordenadores realizam seleção de candidatos para o preenchimento das trinta vagas, e para a edição de 2009, mais de cinqüenta estudantes se inscreveram. Ademais, essa modalidade de experiência já está sendo replicada. Alguns participantes das primeiras edições do GDUCC fundaram o Instituto de Ação Contra Cena, e em parceria com Associação dos Advogados de São Paulo (AASP), em 2009, promoveram o "Curso transdisciplinar de criminologia penitenciária e execução penal", que contemplava formação teórica com

\footnotetext{
${ }^{146}$ Para mais informações sobre o GDUCC, ver: BRAGA e BRETAN (2008).
} 
especialistas - alguns dos coordenadores do GDUCC - e visitas regulares à Penitenciária Feminina de Santana.

Portanto, poderia descrever as zonas de reverberação - desde a literatura até a academia - como feixes discursivos que se articulam com práticas em diversos setores do dispositivo, mas que, por sua própria discursividade, acabam também se descolando das práticas específicas que as conformaram e circulando por todo o dispositivo, reverberando uma situação específica, um processo situado, uma prisão determinada por todo o campo que se articula ao redor da prisão, redefinindo os contornos e traçados desse próprio campo. Por outro lado, do mesmo modo, discursos "leigos" ou "especializados" também acabam por se inscrever em práticas situadas, em intervenções, em reivindicações, em disputas. O egresso que escreve sua autobiografia, a militante feminista que pesquisa os presídios femininos, o jornalista que recruta informantes no interior da prisão, por exemplo, desde postos de enunciação completamente distintos produzem, articulados, uma massa discursiva sobre $o$ encarceramento e suas "verdades", e essas "verdades" são mobilizadas em outros pontos da rede, quando um estudante vai desenvolver um programa de reinserção para egressos, um instituto de pesquisa vai prestar assessoria a uma agência governamental, ou um coletivo de amigos e familiares de presos se reúne para lutar por uma causa, etc. É exatamente por essa constitutiva fluidez entre discursos e práticas, que as zonas de reverberação não são redutíveis aos campos gravitacionais, nem às camadas tectônicas do dispositivo, ao mesmo tempo em que refletem os movimentos e deslocamentos que se dão em cada uma dessas dimensões que o compõem.

\section{9 - Enlaces}

Esferas gravitacionais, camadas tectônicas e zonas de reverberação são como três macro-regiões do dispositivo carcerário que puderam ser cartografadas no decorrer dessa pesquisa. Como se procurou demonstrar, dentro delas, entre elas e para além delas, múltiplos agentes, práticas e discursos se articulam e circulam numa rede complexa que se estrutura ao redor e através da prisão, e que se chamou de dispositivo 
carcerário. Agora, para interromper essa cartografia, retomo as trajetórias de Pedro e Amaro, procurando esboçar o percurso que empreenderam depois de se afastarem do sistema penitenciário paulista naquele fatídico ano de 2001, para em seguida ressituá-los no mapa do reconfigurado dispositivo carcerário.

Em 2001, Pedro iniciou sua formação religiosa para tornar-se um missionário da Igreja Católica. Seu processo formativo lança luz sobre as condições de possibilidade de tamanha presença de agentes religiosos na estruturação de múltiplas entidades e organizações civis em torno da questão prisional, e não só dela. Pedro foi formado num verdadeiro périplo pelos problemas sociais do mundo contemporâneo: prestou assistência jurídica a camponeses sem-terra no interior da Bahia; junto ao Movimento dos Trabalhadores Rurais Sem-Terra (MST) e à Pastoral da Terra no Pará; fez “estágios” pastorais em favelas na Nicarágua e em prisões da Bolívia. Em seguida, ingressou num seminário em Goiânia, onde cursou Filosofia e Teologia, enquanto intensificava a atividade na Pastoral Carcerária. Segundo ele conta, nesse período que efetivamente se familiarizou com os trâmites jurídicos da execução penal, prestando assistência jurídica cotidianamente nos presídios da região.

Depois de formado missionário, a meados de 2005, Pedro veio integrar a direção da seção estadual da Pastoral Carcerária. Este era um momento decisivo da (re)estruturação do campo: o momento em que a Pastoral Carcerária e diversas outras entidades civis, que se articulavam em torno da questão prisional, não só dialogavam com as altas esferas estatais, mas, efetivamente, as (re)estruturavam. Pedro retornou a São Paulo no auge do movimento pela estruturação da Defensoria Pública, acompanhando os episódios mais determinantes desse longo processo.

Depois de dois anos atuando na direção estadual da Pastoral Carcerária, Pedro foi convidado a colaborar na direção nacional da entidade. Nessa nova posição ele pôde conhecer os sistemas prisionais de todo o mundo: dos Estados Unidos à Tailândia, passando por diversos países da Europa e América Latina. No Brasil, sua vida também foi viajar, ministrando cursos de formação para os mais de 3.000 agentes pastorais que visitam presídios em todo o país. Não obstante siga fazendo intervenções pontuais de assistência jurídica e religiosa, seu foco de atuação ampliou-se sobremaneira, de tal modo que, além de denunciar casos de violações de direitos num xadrez de delegacia, também se articula com congressistas e assessores parlamentares para barrar algumas e 
promover outras mudanças legislativas no campo penal, articula representantes de diversas religiões em prol da liberdade religiosa no cárcere, participa de debates públicos sobre a criminalização da pobreza, a funcionalidade ou não das penas alternativas, as possibilidades do voto dos presos, etc. No final de 2009, Pedro voltou ao ambiente universitário, ingressando no mestrado em direito na Universidade de Brasília (UNB), para desenvolver projeto de pesquisa sobre os sistemas de monitoramento eletrônico de sentenciados, adentrando também numa zona de reverberação de escala internacional. Como se pode perceber, se se acompanhasse as múltiplas atividades atuais de Pedro, mesmo que num brevíssimo lapso de uma semana, já seria possível realizar toda uma outra cartografia do dispositivo carcerário, e não só paulista, mas nacional e global, já que é nessa escala que atualmente se desenrolam muitas de suas articulações e movimentações.

Amaro, mais a contra-gosto e mais de longe, também se manteve atado ao dispositivo carcerário. Quando deixou de trabalhar na Penitenciária do Estado, em 2001, um problema que já se esboçava na sua vida se radicalizou: o alcoolismo. Amaro passou um período entre o embriagar-se e as tentativas de recomeçar a vida, enquanto tirava todas as férias e licenças-prêmio acumuladas em tantos anos de serviço. Tentou voltar ao ramo das próteses dentárias, mas sua coordenação motora já estava comprometida pelo vício. Quando seus dias de afastamento estavam para acabar, aconselhado pela esposa, Amaro procurou tratamento psiquiátrico para livrar-se do álcool, conseguindo assim mais um período de vínculo com a administração penitenciária, agora sob licença médica. Determinado a recomeçar, pediu internação numa clínica de desintoxicação, pois sabia que essa condição de licenciado por motivos médicos não se sustentaria por muito tempo, além de ter o problema agravante da significativa redução salarial que o afastamento implicava. As contas se acumulavam e era imperioso que ele retomasse o equilíbrio para conseguir um novo trabalho, a internação foi a medida radical que ele julgou necessária.

Porém, na clínica, Amaro se deu conta de como seria difícil desvencilhar-se daquele passado de prisão. Uma vez internado numa instituição relativamente parecida com as que trabalhara, reviveu muito do que era o encarceramento que tão bem conhecia, só que agora não mais na posição de vigilante, mas de vigiado. A clínica era particular e mantinha convênio com o governo estadual, de modo que abrigava pessoas de classe 
média, dependentes de diversas drogas, e funcionários públicos licenciados, também por motivos vários. Amaro foi alocado num quarto com outro agente penitenciário, e um investigador de polícia, ambos sofrendo do mesmo mal que lhe afligia: o alcoolismo. Logo, os três criaram uma boa amizade, jogavam baralho, faziam exercícios, contavam histórias, viam televisão, sempre juntos.

Conforme ia se adaptando à rotina da instituição e conhecendo melhor o grupo de internos, Amaro foi percebendo que havia certas coisas que não estavam "certas" naquela clínica. Um menino rico que, na cantina, seguidamente extorquia um senhor de idade depressivo; notícias de furtos diversos iam circulando durante um jogo de cartas; um rapaz destratava as enfermeiras e caçoava dos pacientes psiquiátricos mais graves, que ficavam atados à cama; outro sujeito, pelo porte avantajado, agredia a quem quer que fosse e por qualquer motivo. Amaro ia levantando informações, identificando os "errados", registrando mentalmente cada falta, até que um dia resolveu tomar uma atitude e mostrar que, naquela clínica, uma “ordem” deveria imperar. Conversou sobre o assunto com seus companheiros de quarto, que sem vacilar, aderiram à causa de moralizar o recinto através da violência.

Numa tarde, carpindo o campo da clínica, Amaro encontrou uma serra e a furtou, levando-a para seu quarto. Com ela, serrou os estrados das camas e construiu com os pedaços de madeira, três porretes. No dia seguinte, devidamente municiados, os três fizeram o grande "acerto de contas". Agrediram a socos e pauladas cada um dos desafetos, sempre concluindo o "corretivo" com orientações para que deixassem aquela clínica e procurassem outro lugar para se tratar, como "faxinas" que mandam desafetos para o "seguro". Amaro encarnava a prisão: o furto da serra, a manufatura de armas, o formar um coletivo, o arquitetar de um plano, o "acerto de contas"; tudo Amaro realizava numa atitude híbrida, um pouco de preso, um pouco de agente penitenciário. Porém, a clínica não era a prisão, todos os agredidos denunciaram Amaro e seu grupo, sem o menor temor da represália. No fim das contas, Amaro e seus colegas é que foram expulsos da instituição; tiveram alta antecipada. Envergonhado, mas sem saber o que poderia ter feito de diferente, Amaro deixou a clínica sentindo-se atado à prisão por dentro, pela mente, pela alma.

Outra vez na rua, não deixou totalmente a bebida, mas conseguiu aos poucos se situar no mercado de trabalho. Envolveu-se numa cooperativa de reciclagem do bairro, e 
atualmente trabalha recolhendo, separando, moendo, pesando e vendendo materiais recicláveis. O dinheiro não é muito, mas basta para uma vida sem luxúria. Do sistema penitenciário, acabou exonerado por acúmulo de faltas, mas ainda a ele se liga através de um processo judicial que vem movendo contra o Estado. Amaro quer a sua aposentadoria como agente penitenciário, uma vez que considera que o Estado deveria ter proposto soluções para o problema que ele mesmo havia lhe causado. O campo político da disputa entre agentes penitenciários e governo estadual é o ponto de inserção atual de Amaro no interior do dispositivo carcerário paulista.

\subsection{0 - (In)conclusões}

Os pontos atuais dos percursos de Pedro e Amaro são também o ponto de parada dessa cartografia. Aqui interrompo o mapear de agentes, práticas e discursos, ainda que existam elementos dispersos que foram identificados e que, por dificuldades várias, não puderam ser aqui incluídos; e ainda que existam tantos outros trajetos possíveis, episódios importantes, discursos imprescindíveis, agentes estratégicos, práticas (re)estruturantes, campos, camadas, zonas compondo o dispositivo carcerário paulista, que são tão ou mais importantes que esses que foram cartografados.

A inconclusividade é a condição dessa cartografia. Ela existe mais para prospectar caminhos, abrir possibilidades, correlacionar dimensões disparatadas, que para oferecer uma imagem fiel e total de uma realidade carcerária. Se os traçados, marcos, referências e passagens que puderam aqui ser apresentados permitem vislumbrar algo do dito e do não dito que compõem um dispositivo, pretende-se ter valido o percurso. 


\section{Considerações finais}

Nessas considerações finais não se encontram grandes conclusões. Nessa dissertação tampouco se pretendeu formular uma teoria geral sobre o encarceramento contemporâneo, que agora poderia ser sinteticamente enunciada. Aqui, portanto, não mais que algumas considerações sobre o percurso teórico e analítico efetuado e algumas perspectivas que se abrem a partir dele.

Como foi indicado na "Introdução", esse documento é expressão de um percurso reflexivo, cognitivo e prático; cada capítulo expressando uma etapa do trajeto e incorporando os obstáculos encontrados, também os contornamentos realizados. No primeiro capítulo - "Hipótese produtiva" -, a explicitação e fundamentação da perspectiva adotada, o ponto cardeal que orientou toda a caminhada, os estudos, as descrições e as análises. A colocação da hipótese produtiva no horizonte da pesquisa é o que garante a unidade do trabalho: tanto na formulação inicial do objeto - os efeitos societários territorializados da massificação do encarceramento -, quanto no resultado "final" - nas cartografias analítico-descritivas do dispositivo carcerário -, sempre o que se procurou explorar e colocar em evidência foi o que produz a prisão fora de seus limites imediatos; e isso nos dois sentidos que a frase admite: o que tal prisão produz na sociedade mais ampla, e que sociedade produz qual prisão.

A passagem entre o primeiro e o segundo capítulos - as "Mediações" sugeridas por Garland para se conceber a prisão no mundo contemporâneo, e a "Pauta" das análises correntes sobre o encarceramento em massa e o processo de massificação do encarceramento - pode ser vista como um passo dado no sentido de sistematizar uma caracterização da prisão contemporânea e do campo social que a produz. É essa caracterização prévia que pauta a primeira aproximação analítica dos diferentes contextos penitenciários estudados - no restante de "Massificação do Encarceramento".

O terceiro capítulo - "Vasos Comunicantes" - explora a segunda acepção da produtividade prisional: a prisão como sujeito da frase. As "Estimativas" das dimensões de um grupo social, direta e indiretamente afetado pelo encarceramento, são uma tentativa de esboçar um predicado para a oração, e a prospecção da dinâmica de alguns 
vasos comunicantes no contexto paulista pode ser considerada um segundo passo nesse sentido.

Se o desenrolar empírico da pesquisa seguisse o roteiro planejado, a dissertação seguiria com um aprofundamento da análise dos vasos comunicantes e das estruturações societárias que promovem em São Paulo, depois em Barcelona; e se finalizaria com um exercício comparativo que buscasse isolar o que fosse exclusivamente produzido pela prisão e pelo seu incremento. A aproximação dos grupos mais direta e indiretamente afetados pelo aumento do encarceramento, e dos vasos comunicantes que os conectam à prisão mostrou-se tarefa mais difícil do que o previsto, e ao invés dos vasos foram os diversos "Mediadores" que circulam entre o dentro e o fora da prisão que acabaram por pautar a pesquisa de campo.

Explicitar essas dificuldades empíricas foi o principal objetivo da inclusão dos "Percursos de campo" nessa dissertação. Além disso, é verdade que eles também funcionaram como uma segunda aproximação a cada contexto punitivo estudado e como uma enunciação do horizonte de possibilidades analíticas que se abria a partir dos materiais e dados recolhidos. O quinto capítulo - "Uma abordagem (im)possível" - é uma breve, porém necessária, reflexão sobre as impossibilidades de efetivação da pesquisa como se havia planejado, e das possibilidades que se abriram com a pesquisa que efetivamente se realizou. A proposta de analisar e descrever o dispositivo carcerário, seus conflitos e deslocamentos recentes, através de cartografias calcadas no trabalho de campo e nas trajetórias de alguns interlocutores da pesquisa, foi a maneira que se encontrou para seguir interpelando a incidência da prisão para além de seus limites em sua positividade e produtividade, não obstante a difusa territorialização. Através da noção de dispositivo carcerário parecia possível explorar, de modo articulado, tanto elementos do que a prisão produzia num determinado contexto, quanto em que contexto um determinado sistema prisional era produzido. Ou seja, ao invés de explorar a produtividade prisional em termos de causas e efeitos gerais da massificação do encarceramento, era o próprio jogo de causas e efeitos que modulava um dispositivo carcerário situado no espaço e no tempo, que parecia emergir da composição dos relatos recolhidos e dos percursos de pesquisa.

Nos capítulos finais, procurou-se desenvolver esse entendimento e essa proposta. Na sistematização dos materiais de pesquisa, na elaboração das cartografias, ficava evidente 
que ao redor e através da prisão, efetivamente, produzia-se um campo difuso e multifacetado de agentes, práticas e discursos, que tanto reagia a transformações nas dinâmicas prisionais, quanto operava nelas deslocamentos importantes. Ainda, sem pretender desenvolver uma teoria geral do encarceramento contemporâneo, a justaposição das cartografias analítico-descritivas parecia ser suficiente para levantar elementos para a reflexão sobre a atualidade e as possibilidades de modulação do dispositivo carcerário.

Em "Uma cartografia do dispositivo carcerário catalão", como que guiado pelos relatos de Manola, Aurora, Filip, podia entrever e reconstituir algumas peças, regiões, momentos e processos que marcaram o desenvolvimento recente tanto do sistema penitenciário da comunidade autônoma, quanto do campo social que se estrutura ao seu redor. A exploração dos processos de estruturação dos aparatos médico-hospitalar, educativo-escolar e voluntário-assistencial, acoplados ao sistema penitenciário e no interior do dispositivo, permitiu complexificar a imagem do "Estado Penal" incapacitante, identificando estratégias subsidiárias, que englobam diferenciados saberes, que se exercem através de outros poderes, e nas quais outras subjetividades se conformam. Sem desconsiderar a importância e o arrebatamento causado pela crescente criminalização da imigração clandestina na Catalunha, e na Europa em geral, a descrição e análise desses outros aparatos permitiu evidenciar como a reestruturação do dispositivo implica numa série de conflitos, de ajustes, de disputas, de invenções e resistências que não poderiam ser abordados em termos estritamente negativos.

Em "Uma cartografia do dispositivo carcerário paulista", por sua vez, através de relatos de agentes inseridos em distintos pontos do dispositivo - como Pedro, Amaro ou Paulo - foi possível vislumbrar como um amplo campo social também se estrutura a partir de uma precariedade constitutiva. A exploração das órbitas gravitacionais, das camadas tectônicas, das zonas de reverberação que compõem o dispositivo, mostrou como ao redor e através de uma prisão que historicamente se caracteriza pela iminência constante da morte violenta, significativas alterações, transformações, importantes abalos, ajustes e reações também se desenvolvem num jogo intrincado de causas e efeitos, que tampouco seriam passíveis de descrição nos termos de uma perene desestruturação.

A partir da leitura de ambas as cartografias, observa-se a estruturação de modulações do dispositivo carcerário que são plasmadas de história e circunstâncias locais, mas que, ao 
mesmo tempo, expressam tendências gerais operantes no mundo ocidental de norte a sul - sejam as reformas legislativas do endurecimento penal, as políticas criminais de "guerra contra as drogas", a crescente incidência de setores mais ou menos organizados da sociedade civil nas operações do dispositivo, etc. Em suma, o cartografar dispositivos situados no tempo e no espaço é também explorar suas características gerais e condições de desenvolvimento atuais.

As perspectivas que se abrem desse percurso teórico, prático e analítico são múltiplas. Sendas importantes do dispositivo foram trilhadas, algumas que são geralmente esquecidas, outras que são repetidamente repisadas, deter-se em uma, ou explorar outros atalhos, desvios e conexões são possibilidades que estão dadas. Se alguns dos marcos e referências aqui pontuados servirem de instrumentos táticos de orientação de outros percursos teóricos ou práticos, se ajudarem a orientar aqueles que trilham pelo dispositivo, seja voluntariamente para conhecê-lo ou para nele combater, seja, involuntariamente, para a ele sobreviver, entende-se que tanto o percurso, quanto o dissertar valeram a pena. 


\section{Imagens}

1

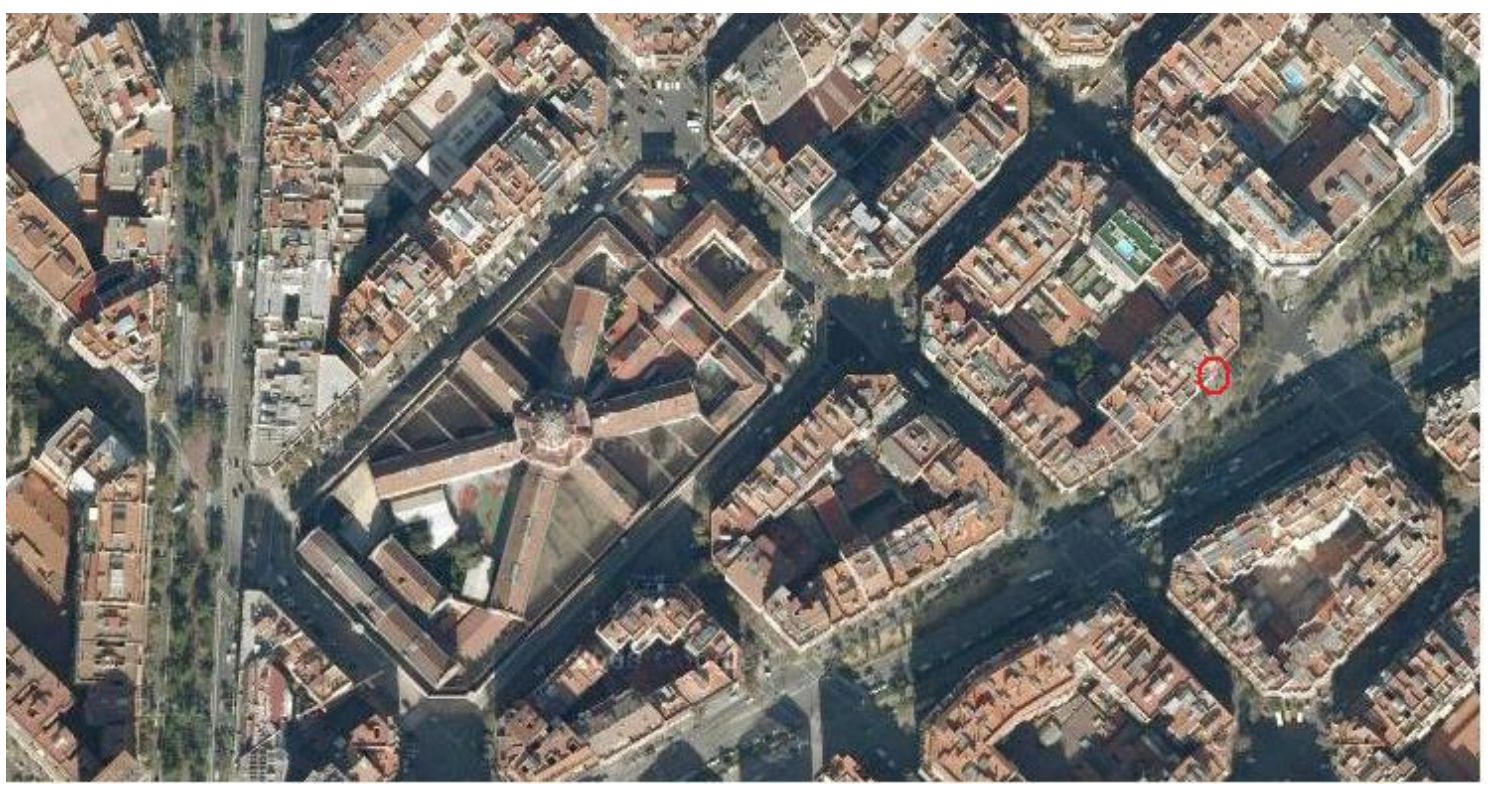

Imagem 1: "Cárcel Modelo" de Barcelona. O círculo vermelho indica o edifício onde vivi.

(Fonte: http://maps.google.com)

2

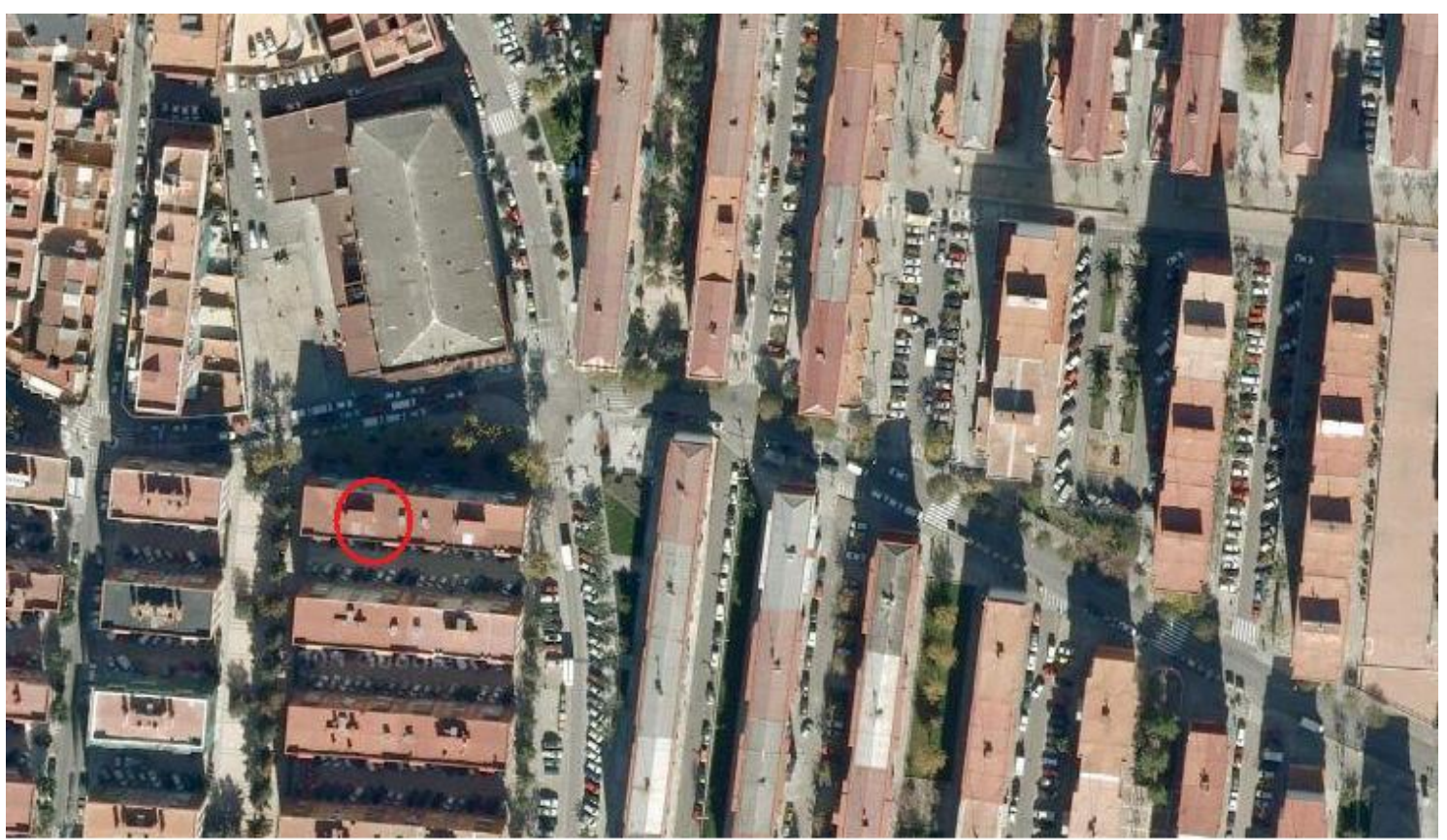

Imagem 2: Coordinadora contra la marginació de Cornellà, bairro de Sant Ildefons, município de Cornellà de Llobregat. (Fonte: http://maps.google.com) 


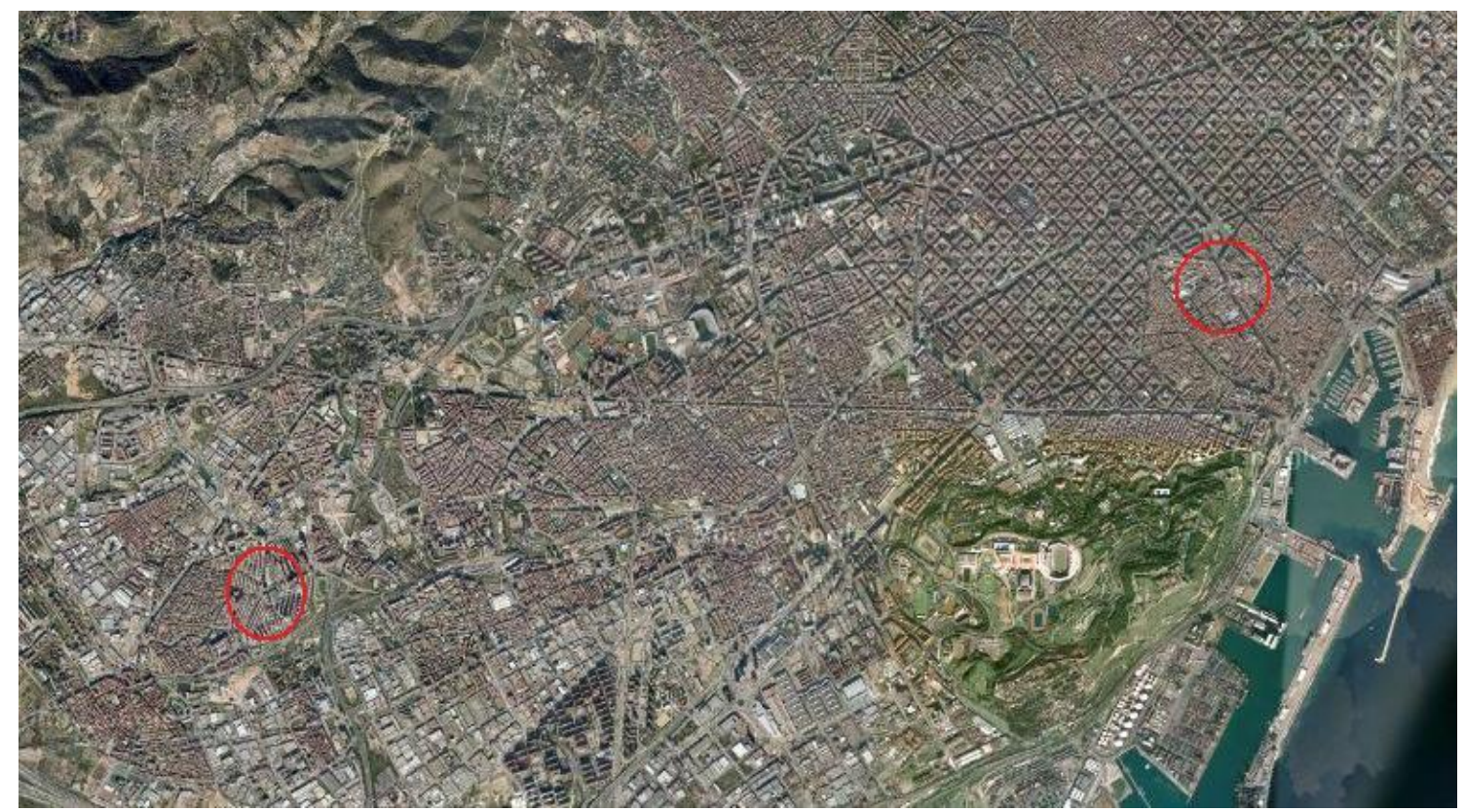

Imagem 3: Sant Ildefons - círculo vermelho à esquerda - e centro de Barcelona - círculo vermelho à direita. (Fonte: http://maps.google.com)

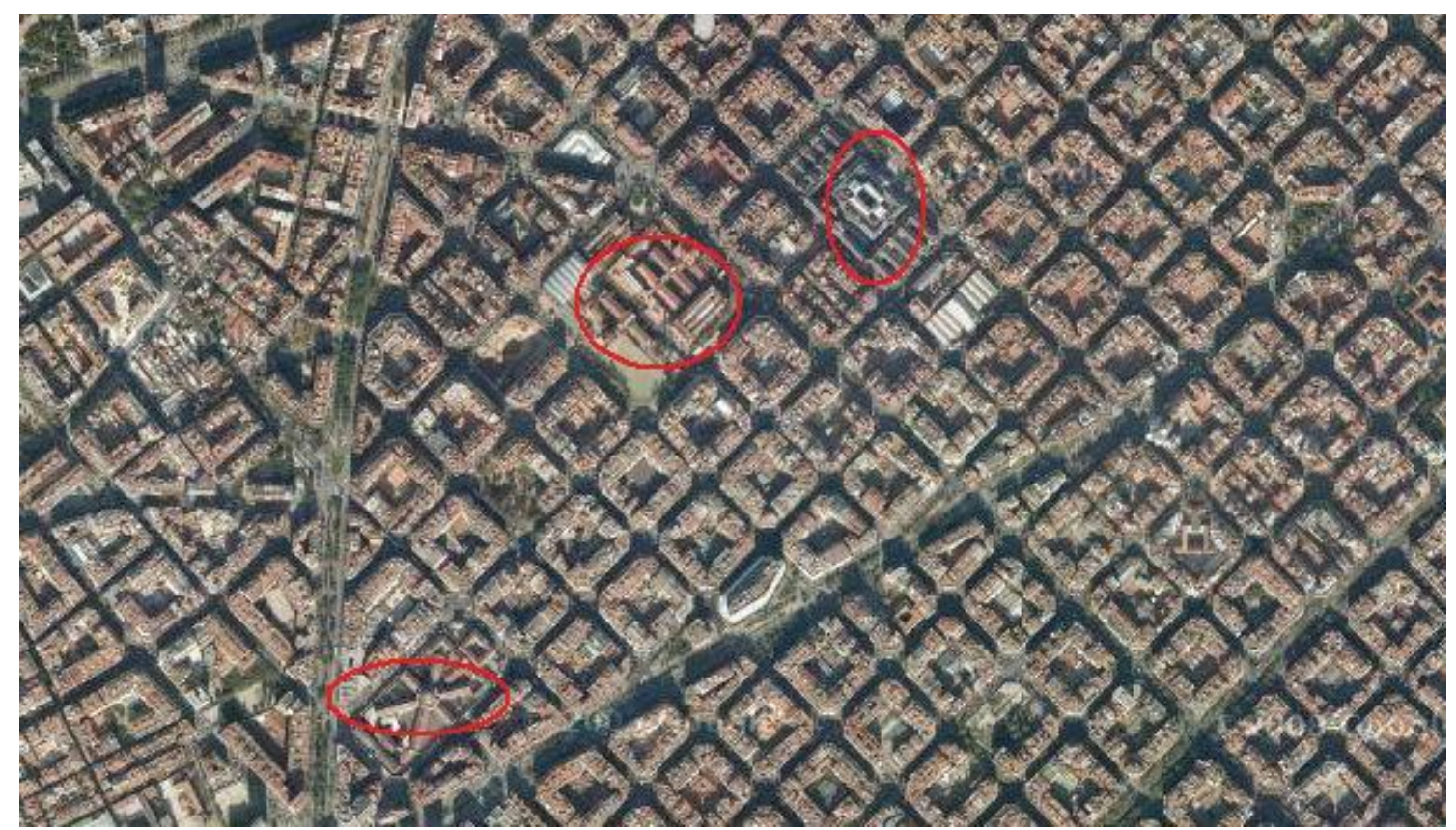

Imagem 4: Eixample Esquerre. Da esquerda para a direita, círculos vermelhos indicam localização da prisão, da escola industrial e do hospital. (Fonte: http://maps.google.com) 


\section{Bibliografia}

ABDALA, V. (2008) "Brasil tem 5\% mais vigilantes privados do que policiais militares" in Agência Brasil de Notícias, Brasília, 02 de jun. de 2008 [online] disponível na internet via: http://agenciabrasil.ebc.com.br/noticias/2008/06/02/materia.2008-06$\underline{02.6503874769}$ (Consulta feita em dezembro de 2009).

ADORNO, S. (1991) "Sistema Penitenciário no Brasil: problemas e perspectivas." in Revista USP - Dossiê Violência, n.9, pp. 65-78.

(1998) "Consolidação Democrática e políticas de segurança pública no Brasil: rupturas e continuidades." in ZAVERUCHA, J. (Org.) Democracia $e$ instituições políticas Brasileiras no final do século XX. Recife. Bagaço.

(2006) "Crimen, punición y prisiones en Brasil: un retrato sin retoques" in Quórum, n.16, pp.41-49.

; SALLA, F. (2007) “Criminalidade organizada nas prisões e os ataques do PCC.” in Revista de Estudos Avançados, 21(61), pp. 07-29.

AMORIM, C. Carlos Amorim, que em "Comando Vermelho: a história secreta do crime organizado" (1993) "CV-PCC: a irmandade do crime" (2003)

ARROYO, A.; MARRÓN, T; CORONAS, D.; LEAL, M. J.; SOLÉ, C.; LALIAGA, A. (2000) "Programa de mantenimiento con metadona (PMM) en prisión: cambios sociales y sanitarios" in Adicciones, v.12, n.2, pp.187-194.

ARTUR, A.T. (2009) “As origens do 'Presídio de Mulheres' do Estado de São Paulo (1930-1950): um levantamento historiográfico" in Anais do IV Encontro de PósGraduandos da FFLCH/USP, [on line] disponível na internet via: http://www.fflch.usp.br/eventos/epog/textos/Angela\%20Teixeira\%20Artur.pdf (Consulta feita em maio de 2010)

BARCELLOS, C. (1997) Rota 66: a polícia que mata. São Paulo:Globo. (2003) Abusado: o dono do morro Dona Marta. Rio de Janeiro:

Record. 
BAUMAN, Z. (1999) "Lei global, ordens locais" in Globalização: as conseqüências humanas. Rio de Janeiro: Jorge Zahar, pp.111-136.

BECKER, G. (1968) "Crime and Punishment: an economic approach" in The Journal of Political Economy, v.76, n.2, pp.169-217.

BERGMAN, M; AZAOLA, E. (2007) "Cárceles en México: cuadros de una crisis" in Revista Latinoamericana de Seguridad Ciudadana, n.1, pp.74-88.

BIONDI, K. (2009) Junto e misturado: imanência e transcendência no PCC. São Carlos: UFSC. Dissertação de Mestrado em Antropologia Social.

BISILliAT, M.B. (Org.) (2003) Aqui Dentro: páginas de uma memória - Carandiru. São Paulo: Imprensa Oficial

BOURGOIS, P. (2000) "Disciplining addictions: the bio-politics of methadone and heroin in the United States" in Culture, Medicine and Psychiatry, n.24, pp.165-195.

BRAGA, A.G.; BRETAN, M.E. (2008) "Teoria e prática da reintegração social: o relato de um trabalho crítico no âmbito da execução penal." in SÁ, A.A.; SHECAIRA, S.S. (Orgs.) Criminologia e os Problemas da Atualidade. São Paulo: Atlas, pp.255-275.

BRAMAN, D. (2003) Family and Incarceration. New Haven: Yale University. Tese de Doutorado em Filosofia.

BUORO, A.B. (1998) Negociando a dignidade humana: os familiares de presos e a percepção de Direitos Humanos. São Paulo: USP. Dissertação de Mestrado em Antropologia Social.

BUTLER, J. (2006) Vida Precaria: el poder de duelo y de la violencia. Barcelona: Paidós.

CALAVITA, K. (2003) 'A 'reserve army of delinquents': the criminalization and economic punishment of immigrants in Spain" in Punishment and Society, vol.5, pp.399-413. 
CALDEIRA, T. P. R. (1991) “Direitos humanos ou 'privilégios de bandidos`? Desventuras da democratização brasileira" in Novos Estudos, n.30, pp.162-174.

(2003) Cidade de Muros: Crime, Segregação e Cidadania em São Paulo. São Paulo: Ed.34/Edusp.

CASTEL, R. (2003) La inseguridad social. Qué es estar protegido? Buenos Aires: Editora Manantial.

CASTELLVÍ, J. (2002) "Los ingenieros de caminos en la transformación de las ciudades españolas a finales del siglo XIX: el caso de Barcelona" in Scripta Nova, vol.6, n.120, [on line] disponível na internet via: http://www.ub.es/geocrit/sn/sn$\underline{120 . h t m}$ (Consulta feita em junho de 2010)

CHANTRAINE, G. (2006) “A prisão pós-disciplinar" in Revista Brasileira de Ciências Criminais, ano 13, n.62, pp. 79-106.

CHIES, L. A.; BARROS, A. L.; LOPES, C. L.; OLIVEIRA, S. F. (2005) "Prisionalização e sofrimento dos agentes penitenciários: fragmentos de uma pesquisa" in Revista Brasileira de Ciências Criminais, n.52, pp. 309-335.

CHRISTIE, N. (1993) Crime Control as Industry: Towards GULAGs, Western Style? London and New York: Routledge.

CHRISTINO, M. (2003) Por Dentro do Crime: corrupção, tráfico, PCC. São Paulo: Escrituras.

CID, J. (2008) "El incremento de la población reclusa en España entre 1996-2006: diagnóstico y remedio" in Revista Española de Investigación Criminológica, n. 6, art.2 [on line] disponível na internet via: http://www.criminologia.net/pdf/reic/ano62008/a62008art2.pdf (Consulta feita em junho de 2010).

CLEMMER, D. (1958) The Prison Comunity. New York: Holt Rinehart and Winston. 
COMFORT, M. L. (2003) "In The Tube of San Quentin: The 'secundary prisonization' of women visiting inmates" in Journal of Contemporary Ethnography, vol. 32, n. 1, pp. 77-107.

(2007) Doing Time Together: love and family in the shadow of the prison. Chicago: University of Chicago Press.

COSTA, H.O. (2001) "Incursões na História das Anistias Políticas no Brasil" in DHNET - História dos Direitos Humanos, [on line] disponível na internet via: http://www.dhnet.org.br/direitos/anthistbr/redemocratizacao1988/homero_anistia.html (Consulta feita em maio de 2010)

COSTA, J; GARCIA, E.; TATJER, M.; VILANOVA, J. (2003) "Infrahabitatge a Catalunya" in Scripta Nova, vol.7, n.146, [on line] disponível na internet via: http://www.ub.es/geocrit/sn/sn-146\%28049\%29.htm (Consulta feita em maio de 2010)

COSTA, M.C. (2004) "Okupas: cultura de contestación” in Revista de Estudios de Juventud, n.64, pp. 117-122.

CRUELLS, M.; IGAREDA, N. (Orgs.) (2005) Women integration and prison. Barcelona: Aurea Editores.

CUNHA, M. (2002) Entre o bairro e a prisão: tráfico e trajetos. Lisboa: Fim de Século. (2004) "A prisão e as suas novas redundâncias" in Direito e Justiça, vol. especial, pp.119-125. (2004-2005) "El tiempo que no cesa: la erosión de la frontera carcelaria" in Renglones, n.58-59, pp.32-41.

DATAFOLHA. (2009) “DNA Paulistano”. Folha de São Paulo [on line] Disponível na Internet via: http://www.nossasaopaulo.org.br/observatorio/index.php?secao=biblioteca (Consulta feita em julho de 2009)

DAS, V.; POOLE, D. (2008) "El estado y sus márgenes: etnografias comparadas." in Cuadernos de Antropología Social, n.27, pp. 19-52.

DEAN, M. (1999) Governmentality. London: SAGE. 
DE GIORGI, A. (2006) A miséria governada através do sistema penal. Rio de Janeiro: Revan.

DELEUZE, G. (1990) “Qué es un dispositivo?” in BALBIER, E. (Org.) Michel Foucault Filósofo. Barcelona: Gedisa, pp.155-163.

DELGADO, M (2007) La ciudad mentirosa: fraude y miseria del "modelo Barcelona". Madrid: Los Libros de la Catarata.

DEPEN - Departamento Penitenciário Nacional. (2008) Metas 2: Conselhos da Comunidade. Ministério da Justiça, Governo Federal.

(2010) "Infopen - estatística". Ministério da Justiça, Governo Federal [online], disponível na internet via: http://www.mj.gov.br/data/Pages/MJD574E9CEITEMIDC37B2AE94C6840068B1624 D28407509CPTBRNN.htm. (Consulta feita em maio de 2010).

DÍAZ, V.P.; MIRANDA, B.A.; e ENRÍQUEZ, C.G. (2001) España ante la inmigración. Barcelona: Fundación La Caixa.

DJ - Departament de Justícia. (2010a) "Descriptors estadístics de serveis penitenciaris $i$ rehabilitació." Generalitat de Catalunya [online], disponível na internet via: http://www.gencat.cat/justicia/estadistiques_serveis_penitenciaris/ (Consulta feita em maio de 2010).

Generalitat de Catalunya [online], disponível na internet via: http://www20.gencat.cat/portal/site/Justicia/menuitem.51bb51de98b3c1b6bd6b6410b0c 0e1a0/?vgnextoid=0d56f31f87203110VgnVCM1000008d0c1e0aRCRD\&vgnextchanne

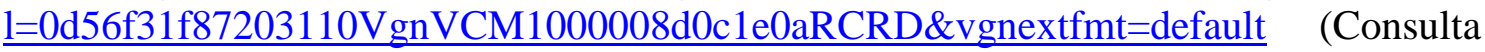
feita em maio de 2010).

DOWNES, D. (2001) "The macho penal economy: mass incarceration in the United States - a European perspective” in Punishment \& Society, vol.3, n.1, pp.61-80.

DUFEE, D. (1974) "The correctional officer subculture and organizational change" in Journal of Research in Crime and Delinquency, n.11, pp.155-172. 
EDWARDS, A.R. (1970) "Inmate adaptations and socialization in the prison." in Sociology, vol.4, n.2, pp.213-225.

ELLIS, D. (1979) "The prison guard as a carceral Luddite: a critical review of the MacGuigan Report on the penitentiary system in Canada" in Canadian Journal of Sociology, vol.4, n.1, pp43-64.

FEBRASPEN - Federação Brasileira dos Servidores do Sistema Penitenciário. (2009) "A Polícia Penal no Contexto da Segurança Pública: apontamentos para a Primeira Conferência Nacional de Segurança Pública." Brasília: Primeira Conferência Nacional de Segurança Pública, Eixo Temático n.6 - Princípios e Diretrizes.

FELTRAN, G. S. (2008) Fronteiras de tensão: um estudo sobre política e violência nas periferias de São Paulo. Campinas: UNICAMP. Tese de Doutorado em Ciências Sociais.

FIGUERUELO, A. (1970) Cataluña: crónica de una frustración. Madrid: Guadiana.

FISCHER, R. M., ADORNO, S. (1987) “Políticas penitenciárias, um fracasso?” in Lua Nova, vol.3,n.4, pp.70-79.

FOUCAULT, M. (1978) História da loucura na Idade Clássica. São Paulo: Perspectiva. (1980) Microfísica del poder. Madrid: Ed. La Piqueta. (1987) Historia de la Sexualidad 1: La Voluntad de Saber. Madrid: Siglo XXI. (1996) Vigiar e Punir: história da violência nas prisões. Petrópolis: Ed.Vozes. (2006) Seguridad, territorio y población: curso en Collège de France: 1977-1978. Buenos Aires: Fondo de Cultura Económica. (2008) Nascimento da Biopolítica. São Paulo: Martins Fontes. 
FUNAP - Fundação Dr. Manoel Pedro Pimentel. (2010) "Censo Penitenciário 2002." SAP - Governo do Estado de São Paulo [online], disponível na Internet via: http://www.sap.sp.gov.br/ (Consulta feita em maio de 2010).

GARLAND, D. (1985) Punishment and Welfare: A History of Penal Strategies. Aldershot: Gower.

(1999) "As contradições da 'sociedade punitiva': o caso britânico" in Revista de Sociologia e Política, n.13, pp. 59-80.

(Org.) (2001) Mass imprisionment: social causes and consequences.

London: SAGE.

(2005) La cultura del control: Crímen y orden social en la sociedad contemporánea. Barcelona: Editorial Gedisa.

GIMÉNEZ, A. (1994) Extranjeros en su propia tierra: los gitanos. Barcelona: Virus.

GODOI, R. (2008a) "Entre la Calle y la Cárcel: una investigación etnográfica exploratoria sobre el flujo carcelario-urbano que pasa por Barcelona" Barcelona: UAB. Dissertação de Máster Oficial em Investigação Etnográfica, Teoria Antropológica e Relações Interculturais.

(2008b) "Entre el hogar y la cárcel: una historia de vida (des)estructurada por las instituciones penitenciarias" in Quaderns-e de l'ICA, n. 11-a. [on line] disponível na internet via: http://www.antropologia.cat/node/6079 (Consulta feita em junho de 2010)

(2009a) "Uma vida em Barcelona entre o hospital e a prisão" in Revista Brasileira de Ciências Criminais, ano 17, n. 76, pp. 348-371.

(2009b) "Gérer le vivre-ensemble dans et hors de la prison: la trajectoire d'un agent pénitentiaire à un moment de transition" in CABANES, R.; GEORGES, I. São Paulo: la vie d'en bas. Paris: L’Harmattan, pp.151-166.

(2009c) Prisão, periferia e seus vasos comunicantes em tempos de encarceramento em massa. Texto apresentado no seminário Crime, violência e cidade. São Paulo: PPGS-USP, NEV (no prelo).

(2009d) “PCC, 1993-2006, São Paulo, Brasil: una cronología del Primeiro Comando da Capital" in Viscera, n.3, pp.06-11.

GÓES, E. M.; MAKINO, R.L. (2002) "As unidades prisionais do Oeste Paulista: implicações do aprisionamento e do fracasso da tentativa da sociedade de isolar por completo parte de si mesma" in Terra Livre, n.19, pp.163-176. 
$\overline{2), \text { pp. 219-238. }}$

(2004) "Transição política e cotidiano penitenciário" in História, 23(1-

GOFFMAN, E. (1974) Manicômios, Prisões e Conventos. São Paulo: Ed. Perspectiva. (1988) Estigma: notas sobre a manipulação da identidade deteriorada.

Rio de Janeiro: LTC.

GONZÁLEZ, E.B.; TREMPS, M.C. (1986) "La Ciutat Satèl-lit de Sant Ildefons (Cornellà de Llobregat)" in Treballs de la Societat Catalana de Geografia, n.7-8, pp.31-40.

GRIMBERG, S.V. (2009) "Luta de guerreiros, castigos de ninjas e amor de rainhas: etnografia de uma rebelião prisional." São Carlos: UFSC. Dissertação de Mestrado em Antropologia Social.

HULSMAN, L.; CELIS, J. B. (1997) Penas perdidas: o sistema penal em questão. Niterói: Luam.

IBGE - Instituto Brasileiro de Geografia e Estatística (2006) "Estatísticas do Século $X X$." Rio de Janeiro: IBGE - Centro de Documentação e Disseminação de Informações. [livro e DVD online] disponível na internet via: http://www.ibge.gov.br/seculoxx/default.shtm (Consulta feita em maio de 2010).

disponível

na

(2010) "População." [online] internet via:

http://www.ibge.gov.br/home/mapa_site/mapa_site.php\#populacao (Consulta feita em maio de 2010).

IDESCAT - Institut d'Estadística de Catalunya (2010). “Anuari estadístic de Catalunya - Població. " [on line] disponível na internet via: http://www.idescat.cat/pub/?id=aec\&n=29 (Consulta feita em junho de 2010).

INE - Instituto Nacional de Estadística. (2010a) "Seguridad y Justicia." INEbase Sociedad [on line] disponível na internet via: http://www.ine.es/inebmenu/mnu_justicia.htm (Consulta feita em junho de 2010)

(2010b) "Cifras de población y Censos demográficos." INEbase - Demografía y población [on line] disponível na internet via: http://www.ine.es/inebmenu/mnu_cifraspob.htm (Consulta feita em junho de 2010) 
JACOBS, J.; RETSKY, H. (1975), "Prison Guard" in Journal of Contemporary Ethnography, vol.4, n.1, pp.5-29.

JOCENIR. (2001) Diário de um Detento. São Paulo: Labortexto.

JOZINO, J. (2005) Cobras e Lagartos: A vida íntima e perversa nas prisões brasileiras. Quem manda e quem obedece no partido do crime. Rio de Janeiro: Objetiva. (2008) Casadas com o crime. São Paulo: Letras do Brasil.

KAHN, T. (Org.) (2000) Polícia Comunitária: avaliando a experiência. São Paulo: ILANUD.

KAMINSKI, M.M. (2003) "Games Prisoners Play: allocation of social roles in a total institution" in Rationality and Society, vol.15, n.2, pp.188-217.

KUHN, A. (2001) "Incarceration rates across the world" in TONRY, M. (org.) Penal Reform in Overcrowded Times. New York: Oxford University Press, pp. 101-116.

LIMA, R. S. (2009) Criminalidade Violenta e Homicídios em São Paulo: fatores explicativos e movimentos recentes. Texto apresentado no seminário Crime, violência e cidade. São Paulo: PPGS-USP, NEV (no prelo).

LIMA, W. S. (2001) Quatrocentos contra um: uma história do Comando Vermelho. São Paulo: Labortexto.

LOPES, R. (1998) "Atualidades do discurso disciplinar: a representação da disciplina na fala dos agentes penitenciários" São Paulo: USP. Dissertação de Mestrado em Psicologia.

MAIA, A.N.; MUNGIOLI, M.S. (2002) "Prisioneiras da Opressão: aspectos da vida de familiares e amigos de internos no sistema prisional." São Paulo: AFAISCA. 
MARCUS, G. E. (1995) "Ethnography in/of world system: the emergence of multi-sited ethnography" in Anual Review of Anthropology, v. 24, pp.95-117.

MARQUES, A. (2009) Crime, proceder, convívio-seguro: um experimento antropológico a partir de relações entre ladrões. São Paulo: USP. Dissertação de Mestrado em Antropologia Social.

MARQUES, E.; BICHIR, R.; PAVEZ, T.; ZOPPI, M.; MOYA, M.E.; PANTOJA, I. (2007) "Redes Pessoais e Pobreza em São Paulo" in DIAS, L. (Org.) O uso das redes sociais nas Ciências Humanas. Florianópolis: Ed. da UFSC. [on line] disponível na internet via: http://www.centrodametropole.org.br/pdf/2007/Anpocs2007ColetivoFinal.pdf (Consulta feita em maio de 2010)

MARTÍNEZ, M. "Viviendas y centros sociales en el movimiento de okupación: entre la autegestión doméstica y la reestructuración urbana" in Scripta Nova, vol.7, n. 146. [on line] disponível na internet via: http://www.ub.es/geocrit/sn/sn-146(109).htm (Consulta feita em maio de 2010)

MARZO, A. (1990) Alfabetización en el medio penitenciario. Madrid: Editorial Popular.

MASÓ, M.M. (2002) “La 'gestión' penal de la inmigración: otra excepción al Estado de derecho" in Panóptico, n.3, pp.174-179.

MATSUDA, F.E. (2009) "A Medida da Maldade: periculosidade e controle social no Brasil.” São Paulo: USP. Dissertação de Mestrado em Sociologia.

MAUER, M. (2001) "The causes and consequences of prison growth in the United States" in Punishment \& Society, vol.3, n.1, pp.9-20.

; CHESNEY-LIND, M. (Orgs.) (2002) Invisible Punishment: the collateral consequences of mass imprisonment. New York: New Press.

MELO, L.W. (2007) A Defensoria Pública como Meio de Acesso do Cidadão à Justiça. Fortaleza: UNIFOR. Monografia de Bacharelado em Direito. 
MELOSSI, D. e PAVARINI, M. (2006) Cárcere e Fábrica: as origens do sistema penitenciário (XVI-XIX). Rio de Janeiro: Revan.

MENDES, L. A. (2001) Memórias de um Sobrevivente. São Paulo: Cia. das Letras. (2005) Às cegas. São Paulo: Cia. das Letras.

MESQUITA NETO, P. (1997) "Programa Nacional de Direitos Humanos: continuidade ou mudança no tratamento dos Direitos Humanos no Brasil" in Revista CEJ, (s.n.), pp. 82-91.

MEZAN, R. (2010) "Estímulo a impunidade" in Folha de São Paulo, Caderno Mais, 28 de fev. de 2010.

MI - Ministerio del Interior (2010a) "Estadística penitenciaria." Gobierno de España [online], disponível na internet via: http://www.institucionpenitenciaria.es/opencms/opencms//documentos/estadisticas.html (Consulta feita em junho de 2010)

de España [online], disponível na internet via:
http://www.institucionpenitenciaria.es/opencms/opencms/centrosPenitenciarios (Consulta feita em junho de 2010)

MISSE, M. (1999) Malandros, Marginais e Vagabundos. A acumulação social da violência no Rio de Janeiro. Rio de Janeiro: IUPERJ, Tese de Doutorado em Sociologia.

(2006) Crime e Violência no Brasil Contemporâneo: Estudos de sociologia do crime e da violência urbana. Rio de Janeiro: Lumen Juris.

MITJAVILA, M. (1999) "El riesgo y las dimensiones institucionales de la modernidad" in Revista de Ciencias Sociales, n. 15. [on line] disponível na internet via: http://www.rau.edu.uy/fcs/soc/Publicaciones/Revista/Revista15/Mitjavila.html (Consulta feita em maio de 2010)

(2002) "O risco como recurso para a arbitragem social" in Tempo Social, 14(2), pp.129-145.

MJ - Ministério da Justiça (2010) "Segurança Pública - Estatísticas." Governo Federal [online], disponível na internet 
http://portal.mj.gov.br/senasp/data/Pages/MJCF2BAE97ITEMIDEE8A5056B03A46BF A4DAD390E0FDF1C7PTBRNN.htm (Consulta feita em maio de 2010)

MUNIZ, C. B. (2009) “A Defensoria Pública de São Paulo na Defesa dos Direitos Socias" in Revista Brasileira de Ciências Criminais, v.17, n.77, pp.331-341.

MUNS, E. P. (2003) Programes de Manteniment amb Metadona a Barcelona: un estudi de cost-efectivitat. Barcelona: UAB. Tese de Doutorado em Psicologia da Educação.

MYASHIRO, S. G. (2006) "Filhos de presidiários: um estudo sobre estigma." São Paulo: USP. Dissertação de Mestrado em Educação.

NETO, L.P. (2009) "El Populismo Punitivo en España: del estado social al estado penal" in Anais do Simpósio: Vigilância, Segurança e Controle Social. Curitiba: PUCPR, pp.219-245.

NOGUEIRA, O. (2007) "Preconceito racial de marca e preconceito racial de origem: sugestão de um quadro de referência para a interpretação do material sobre relações raciais no Brasil." in Tempo Social, v.19, n.1, pp. 287-308.

OBALUAÊ, N. (1999) Beco Sem Saída: eu vivi no Carandiru. Rio de Janeiro: Rosa dos Tempos.

O’MALLEY, P; HUTCHINSON, S. (2007) “Reinventing Prevention: Why Did 'Crime Prevention' Develop So Late? ” in British Journal of Criminology, n.47, pp. 373-389.

OSPDH - Observatori del Sistema Penal i els Drets Humans. (2005) El populismo punitivo: análisis de las reformas y contra-reformas del Sistema Penal en España (1995-2005). Barcelona: UB, [on line] disponível na internet via: http://www.libertysecurity.org/article989.html (Consulta feita em maio de 2010).

(2006) La cárcel en el

entorno familiar - Estudio de las repercusiones del encarcelamiento sobre las familias: problemáticas y necesidades. Barcelona: Quaderns de Barcelona. 
PEGORARO, J. (2000) "Violencia delictiva, inseguridad urbana: la construcción social de la inseguridad ciudadana" in Nueva Sociedad, n.167, pp.114-132.

PINCHEIRA, C. (2008) Hacia una política postpenitenciaria en Chile. Santiago: RIL.

PINHEIRO, P. S.; MESQUITA NETO, P. (1997) "Programa Nacional de Direitos Humanos: avaliação do primeiro ano e perspectivas" in Revista de Estudos Avançados, 11(30), pp.117-134.

(Org.) (1999) Continuidade Autoritária e Construção da Democracia - Relatório Final. São Paulo: NEV, [online] disponível na internet via: http://www.nevusp.org/downloads/down000.pdf (Consulta feita em maio de 2010)

(2001) "Transição política e não-estado de direito na República" in SACHS, I; WILHEIM, J.; PINHEIRO, P. S. (Orgs.) Brasil: um século de transformações. São Paulo: Cia. das Letras.

PRADO, A.C. (2003) “Cela Forte Mulher.” São Paulo: Labortexto.

PRODUÇÃO COLETIVA (2004) La Cárcel Modelo de Barcelona 1904-2004. Barcelona: Ateneo Libertario Al Margen, Likiniano Elkartea, Ateneo Libertari Poble Sec, Etcétera [on line] disponível na internet via: http://www.sindominio.net/etcetera/PUBLICACIONES/con_otros/modelo2.pdf (Consulta feita em maio de 2010)

PROJETO BRASIL NUNCA MAIS (1985) Brasil: nunca mais - um relato para a história. Petrópolis: Vozes.

PUESCHEL, J.; MOGLIA, R. (1977) "The effects of the penal environment on familial relationships" in The Family Coordinator, vol.26, n.4, pp.373-375.

RAMALHO, J. R. (2002) O mundo do crime: a ordem pelo avesso. São Paulo: IBCCRIM.

RELATÓRIO DO I ENCONTRO NACIONAL DE DIREITOS HUMANOS (1982) in DHNET - Movimento Nacional de Direitos Humanos, [on line] disponível na internet via: http://www.dhnet.org.br/mndh/encontros/iencontro/relatorio.htm (Consulta feita em maio de 2010). 
ROCA,J.M. (Org.) (1994) El proyecto radical: auge y declive de la izquierda revolucionaria en España, 1964-1992. Madrid: Los Libros de la Catarata.

RODRÍGUEZ, C.A.; SANS, A.P.; SOLANA, M.S. (2006) “Trajectòries migratòries de la població estrangera a Catalunya: les poblacions marroquina, equatoriana $i$ pakistanesa." Barcelona: GRM-UAB.

ROSA, J.G. (1994) Grande Sertão: Veredas. Rio de Janeiro: Nova Aguilar.

ROSE, N. (1996) "The Death of the Social? Re-figuring the territory of government." in Economy and Society, v.25, n.3, pp. 327-356.

RUBIO, C.L. (2005) "La Revuelta de los Comunes: una primera aproximación al movimiento de presos sociales durante la transición" in Desafectos, n.7, [on line] disponível na internet via: http://www.uclm.es/profesorado/poliver/GrupoEPIP/pdf/CesarLorenzo/LA\%20REVUE LTA\%20DE\%20LOS\%20COMUNES.pdf (Consulta feita em maio de 2010)

RUGGIERO, V. (2005) Delitos de los débiles y de los poderosos: ejercicios de anticriminología. Buenos Aires: Editorial AdHoc.

RUSCHE, G. e KIRCHHEIMER, O. (1984) Pena y Estructura Social. Bogotá: Temiz.

SÁ, A. A. (1998) "Prisionização: um dilema para o cárcere e um desafio para a comunidade" in Revista Brasileira de Ciências Criminais, n.21, pp. 117-123. (2000) "Privação e Delinqüência" in Revista Brasileira de Ciências Criminais, vol.30, pp. 127-142.

SADER, E. (1995) Quando novos personagens entram em cena: experiências e lutas dos trabalhadores da Grande São Paulo (1970-1980). São Paulo: Paz e Terra.

SALLA, F. (1999) As prisões em São Paulo: 1822-1940. São Paulo: Annablume. 
(2000) "Casa de Detenção de São Paulo - passado e presente" in Revista Brasileira de Ciências Criminais, v. 32, p. 213-220

(2006a) "As rebeliões nas prisões: novos significados a partir da experiência brasileira" in Sociologias, n.16.

(2006b) "A Pesquisa Sobre as Prisões: Um Balanço Preliminar" in KOERNER, A.(Org.) História da Justiça Penal no Brasil: pesquisas e análises. São Paulo: IBCCRIM.

(2007) "De Montoro a Lembo: as políticas penitenciárias em São Paulo." in Revista Brasileira de Segurança Pública, ano 1, n. 1, pp. 72-90.

SÁNCHEZ, A. C. (2000) Las políticas de la victoria: la consolidación del Nuevo Estado franquista (1938-1953). Madrid: Marcial Pons.

SANZ, T. R. (2003) Evaluación de programas de prevención y control de tuberculosis. Barcelona: UAB. Tese de Doutorado em Medicina Preventiva.

SAP - Secretaria de Administração Penitenciária. (2010) "Unidades Prisionais." Governo do Estado de São Paulo, [online] disponível na internet via: http://www.sap.sp.gov.br/ (Consulta feita em maio de 2010).

SILVA, J. F. S. (2004) Justiceiros e Violência Urbana. São Paulo: Cortez.

SOARES, T. (2009) "A Defensoria Pública de São Paulo: um modelo inovador de assistência jurídica gratuita" in Revista Brasileira de Ciências Criminais, v.17, n.78, pp.411-425.

SOLSCHENIZYN, A. (1974) Archipiélogo Gulag: 1918-1956. Barcelona: Círculo de Lectores.

SOTELO-BLANCO, O. (1993) El problema de la vivienda: la pesadilla de encontrar un piso hoy. Barcelona: Ronsell.

SOUZA, F. (2007) PCC: a facção. São Paulo: Record. 
SOUZA, P. (1977) A Prisão: histórias dos homens que vivem no maior presídio do mundo. São Paulo: Alfa-Omega.

(1983) O Prisioneiro da Grade de Ferro. São Paulo: Global.

(2006) Sindicato do Crime: PCC e outros grupos. Rio de Janeiro: Ediouro.

SSPRJJ - Secretaria de Serveis Penitenciaris, Rehabilitació i Justícia Juvenil. (2010) "Descriptors estadístics de serveis penitenciaris i rehabiliació." Generalitat de Catalunya, [online] disponível na internet via: http://www.gencat.cat/justicia/estadistiques serveis penitenciaris/ (Consulta feita em maio de 2010).

SYKES, G. M. (1958) Society of Captives: a study of a maximum security prison. Princeton: Princeton University Press.

TATJER, M. (2005) "La vivienda obrera en España de los siglos XIX y XX: de la promoción privada a la promoción pública (1853-1975)" in Scripta Nova, vol.9, n.194, [on line] disponível na internet via: http://www.ub.es/geocrit/sn/sn-194-23.htm (Consulta feita em maio de 2010)

TAULA DE PARTICIPACIÓ SOCIAL. (2009) Què diem les entitats de voluntariat? Barcelona: Centre d’Estudis Juridics i Formació Especialitzada - Jornades de Voluntariat Penitenciari, [on line] disponível na internet, via: http://www20.gencat.cat/docs/Justicia/Documents/ARXIUS/JVPque_entitats_voluntaria t.pdf (Consulta feita em maio de 2010)

TEIXEIRA, A. (2006) Do sujeito de direito ao estado de exceção: o percurso contemporâneo do sistema penitenciário brasileiro. São Paulo: USP. Dissertação de Mestrado em Sociologia.

TELLES, V. S.; CABANES, R. (Orgs.) (2006) Nas tramas da cidade: trajetórias urbanas e seus territórios. São Paulo: Humanitas.

; HIRATA, D. (2007) "Cidade e práticas urbanas: nas fronteiras incertas entre o ilegal, o informal e o ilícito" in Revista de Estudos Avançados, 21(61), pp. 173-191.

153-173. (2009a) "Ilegalismos urbanos e a cidade" in Novos Estudos, n.84, pp. 
(2009b) "Nas dobras do legal e ilegal: ilegalismos e jogos de poder nas tramas da cidade" in Revista Dilemas, (no prelo).

(2009c) São Paulo: tempos da cidade e personagens urbanos: o justiceiro, o matador e o traficante. Texto apresentado no seminário Crime, violência e cidade. São Paulo: PPGS-USP, NEV (no prelo).

THOMPSON, A. (2002) “A Questão Penitenciária.” Rio de Janeiro: Forense.

TONRY, M. (1999) "Why are U.S. incarceration rates so high?" in Crime \& Delinquency, vol.45, n.4, pp. 419-437.

TRAVIS, J. e WAUL, M. (Orgs.) (2003) Prisoners Once Removed: The Impact of Incarceration and Reentry on Children, Families, and Communities. Washington DC: Urban Institute Press.

TUSELL, J. (1999) Historia de España en el siglo XX: IV - la transición democrática y el gobierno socialista. Madrid: Taurus.

VALDÉS, C.G. (1981) La reforma penitenciaria española: textos y materiales para su estudio. Madrid: Instituto de Criminología.

VARELLA, D. (1999) Estação Carandiru. São Paulo: Cia. Das Letras.

VÁRIOS AUTORES (2000) Letras de Liberdade. São Paulo: Madras.

WACQUANT, L. (1998) "A ascensão do Estado penal nos EUA." in Discursos Sediosos, ano 7, n.11, pp. 13-39. (2001) As prisões da miséria. Rio de Janeiro: Jorge Zahar. (2007) Parias Urbanos: marginalidad en la ciudad a comienzos del milenio. Buenos Aires: Manantial.

WAGMAN, D. (2002) "Estadística, delito e inmigrantes." in Gobernabilidad y seguridad sostenible, n.7, [on line] disponível na internet via: 
http://www.iigov.org/ss/article.drt?edi=184297\&art=18432 (Consulta feita em junho de 2008)

(2003) "Los cuatro planos de la seguridad" in Anales del Simposio Política Social y Seguridad Ciudadana, Escuela Universitaria de Trabajo Social de Vitoria-Gasteiz, [on line] disponível na internet via: http://www.iigov.org/ss/article.drt?edi=180699\&art=180703 (Consulta feita em junho de 2008)

WHEELER, S. (1961) "Socialization in correctional communities" in American Sociological Review, vol.26, n.5, pp.697-712.

WIEVIORKA, M. (1997) "O Novo Paradigma da Violência" in Tempo Social, 9(1), pp.5-41.

ZAMORO, P. (2005). A ambos lados del muro. Tafalla: Editorial Txalaparta.

ZENI, B; ANDRÉ DU RAP. (2002) "Sobrevivente André du Rap (do Massacre do Carandiru). São Paulo: Labortexto.

ZIMBARDO, P. (2004) "A Situationist Perspective on the Psychology of Evil: understanding how good people are transformed into perpetrators" in MILLER, A.G. (Org.) The Social Psychology of Good and Evil. New York: Guilford Press, pp.21-50.

; HANEY, C.; BANKS, C. (1973) "Interpersonal dynamics in a simulated prison" in International Journal of Criminology and Penology, vol.1, pp.6997.

ZIMRING F.; HAWKINS, G. (1991) The Scale of Imprisonment. Chicago: University of Chicago Press.

ZINO, J. (1995) "Trayectorias sociales y procesos de identidad en prisión" Tarragona: Arxiu d'Etonografia.

(1997) "Coyunturas de cambio de una cultura institucional" in Revista del Máster Sistema Penal y Problemas Sociales, [on line] disponível na internet via: http://www.ub.es/penal/zino2.htm (Consulta feita em maio de 2010) 


\section{Filmografia}

ANDRIESSEN, G; DALNEY, R. (2006) Cuidar de Quem Cuida. Rio de Janeiro: Curta Cinema - Festival Internacional de Curtas do Rio de Janeiro. 11 min.

BABENCO, H. (2002) Carandiru. São Paulo: HB Filmes, Globo Filmes e Columbia Tristar do Brasil. 146 min.

BURLAMAQUI, L. (2009) Entre a Luz e a Sombra. São Paulo: Zora Mídia. 150 min.

GOMES, T. (2005) Clarissas. Rio de Janeiro: Curso de Cinema Universidade Estácio de Sá. 12 min.

KLEBER, C. (2005) Dia do Caçador. Rio de Janeiro: Curta Cinema - Festival Internacional de Curtas do Rio de Janeiro. 28 min.

LISBOA, D; LISBOA, D. (2006) Freqüência Hanói. Salvador: Cavalo do Cão Filmes. 9 min.

MACHADO, M. (2007) Agna. Brasília: TV Nacional e Radiobrás. 14 min.

MURAT, L. (2004) Quase Dois Irmãos. Rio de Janeiro: Taiga Filmes. 102 min.

NUNES C.; PENHA, J. C. (2004) Aqui Fora. São Paulo: Kinoforum. 8 min.

PINHEIRO, R.; MARTINS, U. (1988) Dia de Visita. São Paulo: produção de Reinaldo Pinheiro. 13 min.

REZENDE, S. (2009) Salve Geral. São Paulo: Toscana Audiovisual e GloboFilmes. 119 min. 
SACRAMENTO, P. (2003) O Prisioneiro da Grade de Ferro: auto-retratos. São Paulo: Olhos de Cão. 123 min.

SAMPAIO, R. (2000) Contatos. Brasília: produção de Rene Sampaio. 14 min.

TOLEDO, P.; MORANDI, J.G. (2007) Can Tunis. Barcelona: Didac Filmes. 84 min. 